\title{
ECOLOGISCHE \\ SYSTEEMBENADERING \\ EN ECOLOGISCHE \\ SYSTEEMANALYSE
}

>IWK 2021-29

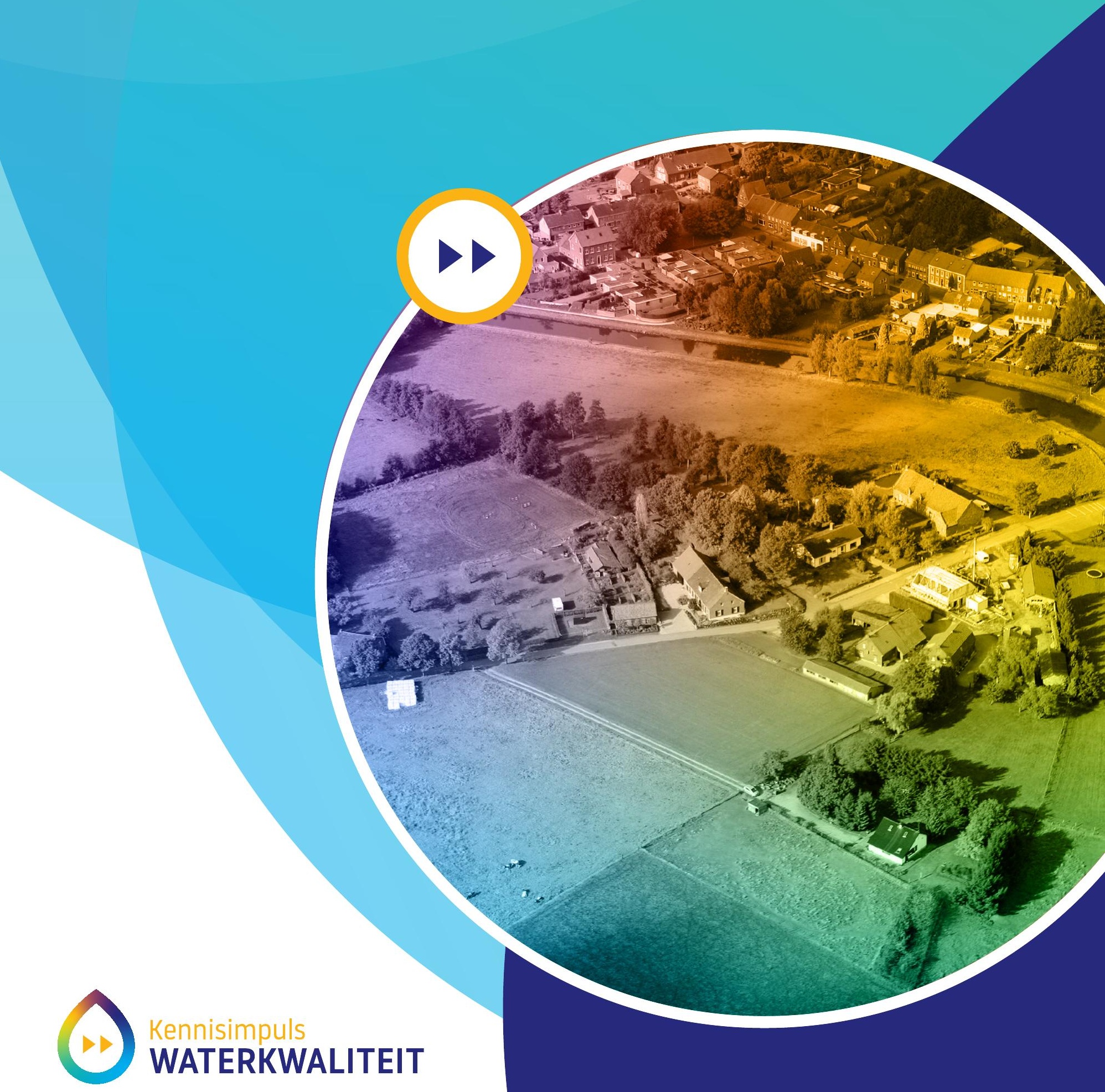




\section{ECOLOGISCHE SYSTEEMBENADERING EN ECOLOGISCHE SYSTEEMANALYSE $\rightarrow$ KIWK 2021-29}

Piet F.M. Verdoschot $\&$ Ralf C.M. Verdonschot

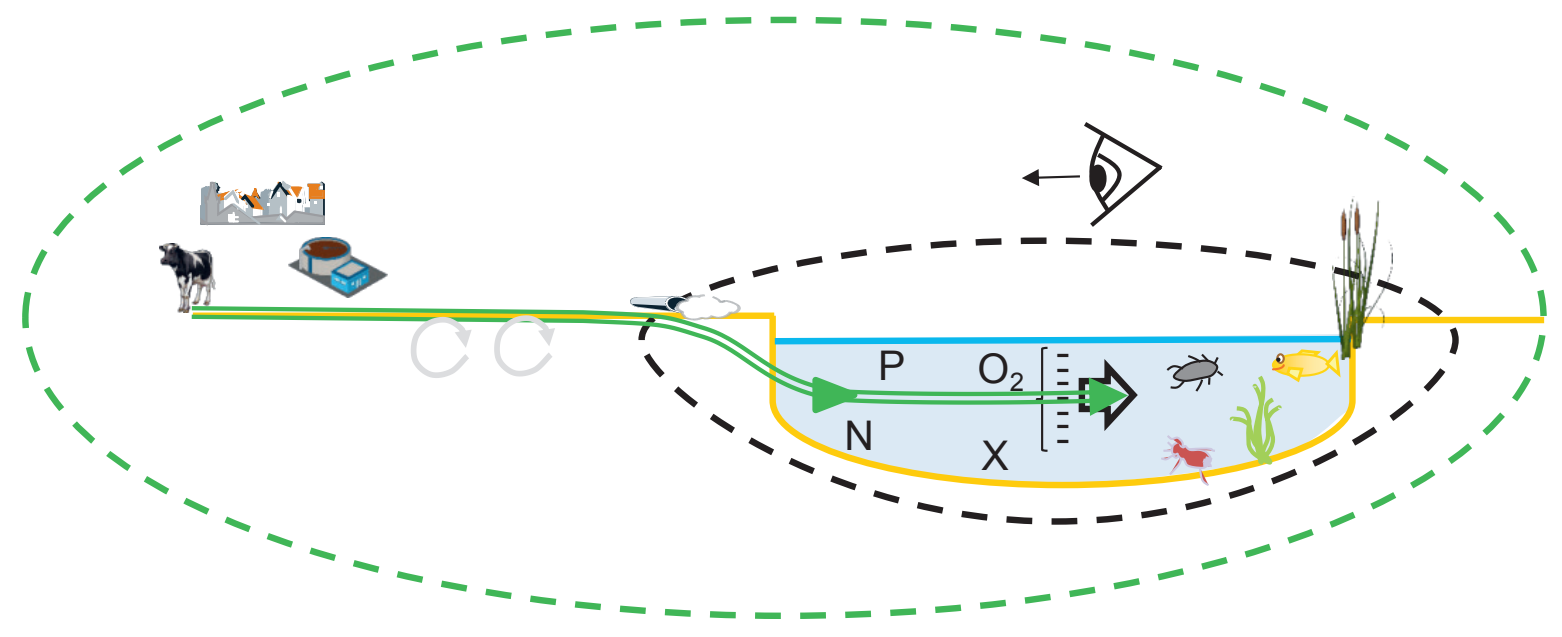




\section{$\rightarrow$ KIWK IN HET KORT}

Deze notitie/memo is geschreven in het kader van het project Systeemkennis en Ecologie van de Kennisimpuls Waterkwaliteit. In de Kennisimpuls werken Rijk, provincies, waterschappen, drinkwaterbedrijven en kennisinstituten aan meer inzicht in de kwaliteit van het grond- en oppervlaktewater en de factoren die deze kwaliteit beïnvloeden. Daarmee kunnen waterbeheerders en andere partijen de juiste maatregelen nemen om de waterkwaliteit te verbeteren en de biodiversiteit te vergroten.

In het programma brengen partijen bestaande en nieuwe kennis bijeen, en maken ze deze kennis (beter) toepasbaar voor de praktijk. Hiermee verstevigen ze de basis onder het waterkwaliteitsbeleid. Het programma is gestart in 2018 en duurt vier jaar. Het wordt gefinancierd door het ministerie van Infrastructuur en Waterstaat, STOWA, waterschappen, provincies en drinkwaterbedrijven.

Kennisimpuls Waterkwaliteit. Beter weten wat er speelt en wat er kan. 


\section{$\rightarrow$ COLOFON}

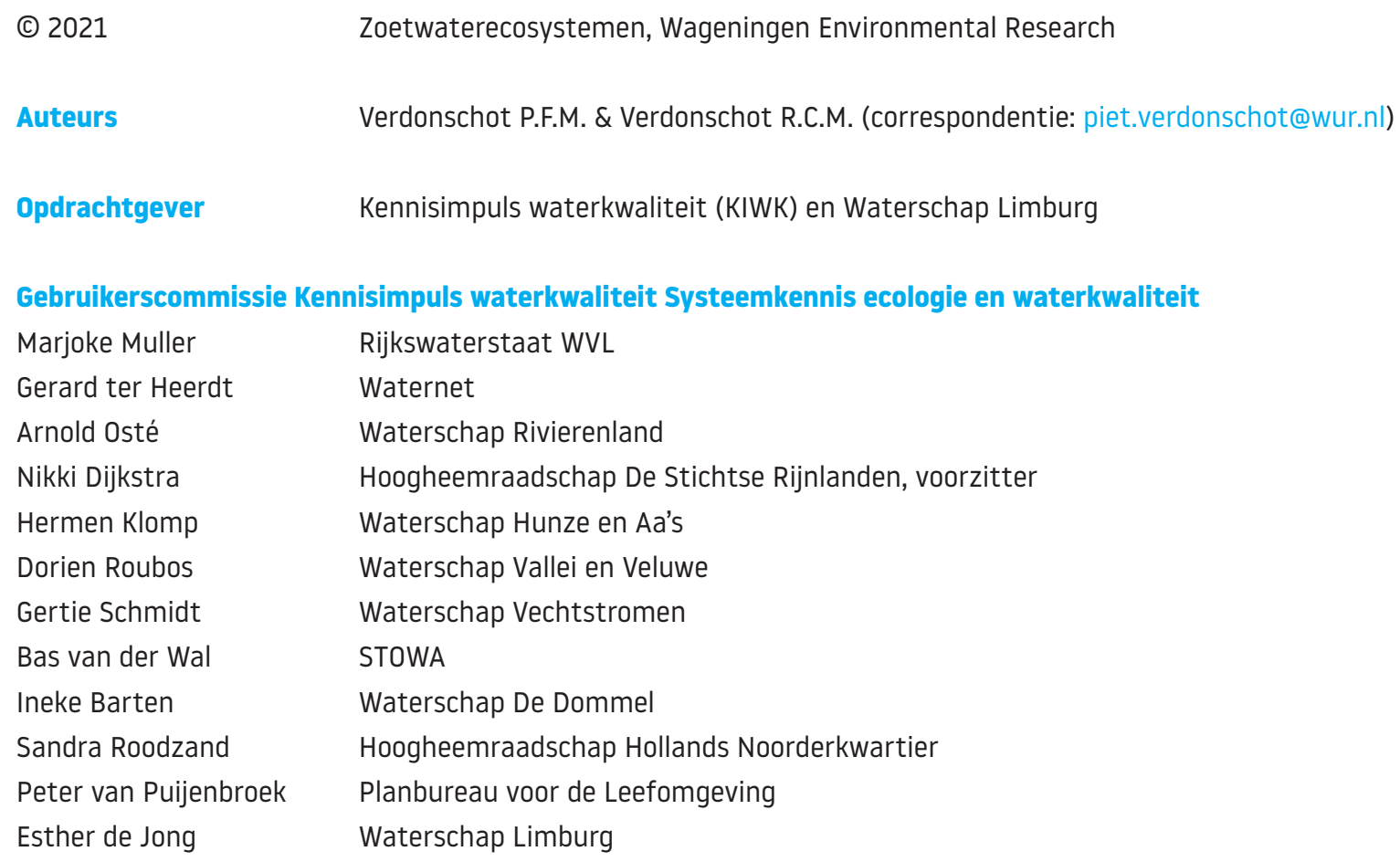

Verdonschot P.F.M. \& Verdonschot R.C.M. (2021). Ecologische systeembenadering en ecologische systeemanalyse. Rapport Kennisimpuls waterkwaliteit (KIWK), Zoetwaterecosystemen, Wageningen Environmental Research, Wageningen UR, Wageningen. 134 pp.

Ecologische sleutelfactoren, ecologisch functioneren, ecosysteemtoestand, macrosysteem, stroomgebied, omgeving, stressor, biotische analyse, respons, maatregelpakket, scenario, handelingsperspectief.

Overname, verveelvoudiging of openbaarmaking van deze uitgave is toegestaan mits met duidelijke bronvermelding. Overname, verveelvoudiging of openbaarmaking is niet toegestaan voor commerciële doeleinden en/of geldelijk gewin, en voor die gedeelten van deze uitgave waarvan duidelijk is dat de auteursrechten liggen bij derden en/of zijn voorbehouden.

Wageningen Environmental Research aanvaardt geen aansprakelijkheid voor eventuele schade voortvloeiend uit het gebruik van de resultaten van dit onderzoek of de toepassing van de adviezen. 


\section{VOORWOORD}

Door de bevolkingsdichtheid en de intensieve menselijke activiteiten staan de Nederlandse oppervlaktewateren onder sterke meervoudige druk. Sinds de invoering van de Kaderrichtlijn water (KRW) zijn veel maatregelen genomen om deze druk te verminderen en daarmee de waterkwaliteit te verbeteren. Waterkwaliteit in termen van de KRW betreft in eerste instantie een gezonde ecologie van het oppervlaktewater. De ecologische sleutelfactoren (ESF) hebben voorwaarden die bepalend zijn voor de ecologische toestand van oppervlaktewateren onder de aandacht gebracht van het waterbeheer. Deze sleutelfactoren laten zien wat de ecologische toestand van het water is, bieden handvatten voor het vaststellen van haalbare doelen en geven richting met betrekking tot het nemen van effectieve maatregelen. Het blijft echter vaak lastig te achterhalen waarom de aangetroffen toestand precies is zoals die is en wat de exacte oorzaken zijn voor het achterblijven van een goede ecologische waterkwaliteit.

Om de meervoudige oorzaken van de achterblijvende waterkwaliteit scherper in beeld te krijgen en het kiezen van effectieve maatregelpakketten verder aan te scherpen is het nodig om op grotere schalen landschapsbreed te kijken hoe de oppervlaktewateren werken en waar de bronnen van de drukken zich bevinden. Door gelijktijdig de bronnen aan te pakken en de oppervlaktewateren te laten functioneren zoals dat past bij het landschap kunnen we meer verbetering bereiken.

Dit rapport presenteert een eenduidige basis voor de ecologische systeemanalyse van stilstaande en stromende oppervlaktewateren. Het verbindt de theorie met de toepassing in de praktijk van het waterbeheer. Hiermee is een fundament gelegd voor een toekomstig duurzaam waterbeheer

\section{Dr. Nikki Dijkstra (Hoogheemraadschap De Stichtse Rijnlanden)}

Voorzitter gebruikerscommissie "Systeemkennis ecologie en waterkwaliteit" Kennisimpuls Waterkwaliteit 


\section{INHOUD}

\section{Voorwoord}

Leeswijzer

DEEL I ECOLOGISCHE SLEUTELFACTOREN EN SYSTEEMANALYSE

1.2 Ecologische sleutelfactoren en ecosysteemtoestanden

1.2.1 De methodiek van de ecologische sleutelfactoren

1.2.2 De toepassing van Ecologische sleutelfactoren (ESF) in de praktijk

1.2.3 Ecosysteemtoestanden

DEEL II ECOLOGISCHE SYSTEEMANALYSE

\section{8}

3 Aanpak ecologische systeemanalyse

3.1 Inleiding 19

3.2 Algemene werkwijze

$4 \quad$ Het macrosysteem 23

4.1 Geografische (ruimtelijke) afbakening en typering 23

$\begin{array}{lll}\text { 4.1.1 Ruimtelijke afbakening } & 23\end{array}$

$\begin{array}{ll}4.1 .2 & \text { Oppervlaktewatertypering }\end{array}$

4.2 Natuurlijk functioneren macrosysteem 24

$5 \quad$ Ecosysteemtoestand en functioneren 26

$5.1 \quad$ Ecosysteemtoestand en ontwikkelingsreeksen 26

5.2 Ecosysteem functioneren 28

5.3 Streefbeeld en ontwikkelingsrichting 29

$6 \quad$ Abiotische stressoren en de biologische respons 30

$6.1 \quad$ Meervoudige abiotische stress 30

$\begin{array}{lll}6.1 .1 \quad \text { Inleiding } & 30\end{array}$

$\begin{array}{lll}6.1 .2 & \text { Identificatie van stressoren } & 31\end{array}$

$\begin{array}{lll}\text { 6.1.3 Grenswaarden en belang van stressoren } & 31\end{array}$

$\begin{array}{lll}6.1 .4 & \text { Berekenen van stress } & 32\end{array}$

6.2 Biologische respons 33

6.3 Koppeling abiotische stress en biologische respons 34

$7 \quad$ Maatregelpakketten en scenario's 35

7.1 Maatregelen en maatregelpakketten 35

$\begin{array}{lll}7.2 & \text { Voorbeeld van een maatregelpakket } & 37\end{array}$

$\begin{array}{lll}7.3 & \text { Scenario's } & 38\end{array}$ 
8.1 Factoren en -processen 40

8.2 Ecologische sleutelfactoren en -processen 41

8.3 Directe relaties tussen sleutelfactoren 43

8.4 'Indirecte' relaties in het waterecosysteem 44

8.5 Biologische relaties 46

8.6 Het 5-S-model 46

$\begin{array}{lll}8.6 .1 & \text { Systeemvoorwaarden } & 47\end{array}$

$\begin{array}{lll}\text { 8.6.2 Stroming } & 49\end{array}$

$\begin{array}{ll}\text { 8.6.3 Structuren } & 50\end{array}$

$\begin{array}{ll}\text { 8.6.4 Stoffen } & 52\end{array}$

$\begin{array}{llr}\text { 8.6.5 Soorten } & 54\end{array}$

8.7 Ruimtelijke en temporele schalen 56

$\begin{array}{lll}8.8 & \text { DPSIRR } & 56\end{array}$

$9 \quad$ Het macrosysteem $\quad 58$

9.1 Geografische eenheden (districten) en watertypen 58

9.2 Het natuurlijk 'macro' functioneren 60

$\begin{array}{lll}9.2 .1 & \text { Klimaat } & 60\end{array}$

$\begin{array}{lll}9.2 .2 & \text { Geohydrologie } & 61\end{array}$

$\begin{array}{lll}9.2 .3 & \text { Geomorfologie } & 63\end{array}$

$\begin{array}{llr}9.2 .4 & \text { Geochemie } & 65\end{array}$

10 Abiotische stress en biologische respons 67

10.1 Menselijke activiteiten 67

$\begin{array}{lll}10.2 & \text { Stressoren } & 71\end{array}$

$\begin{array}{lll}10.3 & \text { Biologische respons } & 74\end{array}$

$\begin{array}{ll}\text { 10.3.1 Indicatoren } & 74\end{array}$

$\begin{array}{lll}\text { 10.3.2 } & \text { Multimetric indices } & 77\end{array}$

$\begin{array}{lll}\text { 10.3.3 Multivariate technieken } & 79\end{array}$

10.3.4 Functionele eigenschappen, levenskenmerken en ecologische preferenties 81

11 Maatregelpakketten en scenario's 86

11.1 Inleiding 86

11.2 Maatregeleffectiviteit 86

DEEL IV HANDELINGSPERSPECTIEF VOOR EEN SESA LAAGLANDBEEK 95

12 Inleiding 96

12.1 Inleiding 96

13 Het macrosysteem $\quad 97$

13.1 Afbakenen en indelen van het onderzoeksgebied 97

$\begin{array}{lll}13.2 & \text { Abiotische referentie } & 97\end{array}$

13.3 Biologische referentie 98 
14.1 Het selecteren van stressoren 100

14.2 Het invullen van stressorklassen 100

$\begin{array}{ll}\text { 14.2.1 (Geo)hydrologische stress } & 102\end{array}$

$\begin{array}{ll}\text { 14.2.2 (Geo)morfologische stress } & 103\end{array}$

$\begin{array}{llr}14.2 .3 & \text { (Geo)chemische stress } & 103\end{array}$

$\begin{array}{llr}\text { 14.2.4 Chemische stress uit diffuse bronnen } & 103\end{array}$

14.2.5 Retentie van nutriënten 106

$\begin{array}{llr}\text { 14.2.6 } & \text { Chemische stress uit puntbronnen } & 106\end{array}$

$\begin{array}{llr}\text { 14.2.7 } & \text { Fysische stress (systeemvoorwaarden) } & 108\end{array}$

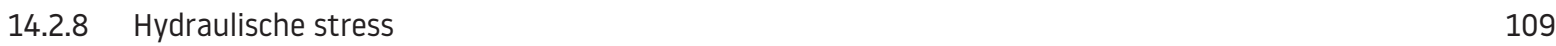

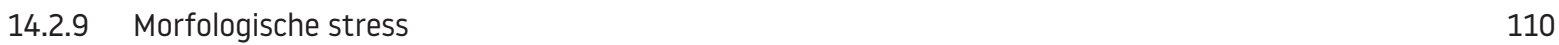

14.2.10 Stress door beheer en onderhoud $\quad 111$

14.2.11 Omgaan met missende gegevens 112

$\begin{array}{lr}\text { 14.2.12 Samenvatting } & 112\end{array}$

15 Bouwstenen van de berekening 114

$15.1 \quad$ Berekenen van de multiple stress $\quad 114$

$\begin{array}{llr}\text { 15.1.1 Ruimtelijke indeling } & 114\end{array}$

$\begin{array}{llr}\text { 15.1.2 } & \text { Berekenen multiple stress per ruimtelijke eenheid/segment } & 114\end{array}$

16 Biotische analyse $\quad 116$

$\begin{array}{lll}16.1 & \text { Inleiding } & 116\end{array}$

$\begin{array}{lll}16.2 & \text { Macrofauna } & 116\end{array}$

$\begin{array}{ll}\text { 16.2.1 Wat is hier: de huidige macrofauna soortenpoule } & 116\end{array}$

$\begin{array}{ll}\text { 16.2.2 Wat kan hier: de potentiële doelsoorten macrofauna } & 118\end{array}$

16.3 Vissen 119

$\begin{array}{ll}\text { 16.3.1 Wat is hier: de huidige vissen soortenpoule } & 119\end{array}$

$\begin{array}{ll}\text { 16.3.2 Wat kan hier: de potentiële doelsoorten vissen } & 119\end{array}$

16.4 Macrofyten 120

$\begin{array}{ll}\text { 16.4.1 Wat is hier: de huidige macrofyten soortenpoule } & 120\end{array}$

$\begin{array}{lr}\text { 16.4.2 Wat kan hier: de potentiële doelsoorten macrofyten } & 120\end{array}$

$17 \quad$ Visualiseren van multiple stress en duiden van knelpunten 122

$18 \quad$ Het kiezen van maatregelpakketten (scenario-analyse) 123

18.1 Milieu-omstandigheden 123

$\begin{array}{lll}18.2 & \text { Visualisatie scenario's } & 123\end{array}$

$\begin{array}{lr}\text { Literatuur } & 124\end{array}$ 


\section{LEESWIJZER}

Dit document beschrijft de achtergronden, uitwerking en het praktisch toepassen van ecologische systeemanalyse. Het document bestaat uit vier delen:

- DEEL I beschrijft kort hoe de Stroomgebiedsbrede Ecologische SysteemAnalyse (SESA) voortbouwt op de Ecologische SleutelFactoren (ESF).

- DEEL II beschrijft de inhoud van de SESA en biedt aanknopingspunten voor de praktijk van het waterbeheer.

- DEEL III bevat het handelingsperspectief voor het toepassen van een SESA. Dit is uitgewerkt voor laaglandbeken.

DEEL IV geeft een verdiepende inhoudelijke uitwerking om de inhoud van Deel I-III beter te begrijpen.

De kern van de ecologische systeemanalyse bestaat uit vier stappen. Iedere stap wordt in deel II in een apart hoofdstuk beschreven. Hoofdstuk 2 gaat in op het macrosysteem. Het beschrijft hoe een gebied geografische (ruimtelijke) kan worden afgebakend en getypeerd. Daarnaast wordt het natuurlijk functioneren van het macrosysteem als 'onderlegger' voor het systeem functioneren en het doel, het implementeren van effectieve maatregelpakketten, geduid. In hoofdstuk 3 worden benaderingen aangedragen om ecosysteemtoestanden en hun functioneren in de praktijk van het waterbeheer te beschrijven. De problemen die in een waterlichaam spelen worden in hoofdstuk 4 gerelateerd aan het landschap en de omgeving waarin ze meestal ontstaan. Problemen komen niet alleen en de complexiteit van hun meervoudige werking zowel als de biologische respons worden onderling vergeleken en voor de praktijk vereenvoudigd en hanteerbaar gemaakt. De problemen worden in hoofdstuk 5 van oplossingen voorzien. Naast streefbeelden en ontwikkelingsrichtingen worden voorbeelden van maatregelen en maatregelpakketten gegeven en wordt het praktische belang van het gebruik van scenario's aangegeven.

Deel III begint in hoofdstuk 1 met een uitgebreide verdiepende uitleg van de bouwstenen. Wat zijn factoren en -processen in het algemeen en wat zijn dan ecologische sleutelfactoren en -processen? Welke onderlinge directe en indirecte relaties onderhouden (sleutel)factore in het waterecosysteem? Wat is de biologische respons? De complexiteit van de factoren en relaties wordt vervolgens vereenvoudigd en voor de praktijk hanteerbaar gemaakt met het 5-S-model waarin ruimtelijke en temporele schalen en oorzaak-gevolg ketens (DPSIRR) een belangrijke rol spelen. Hoofdstukken 2, 3 en 4 geven vervolgens achtergronden bij het macrosysteem (zie Deel II hoofdstuk 2), de stressoren en biologische responsen (zie Deel II hoofdstuk 3) en de maatregelen en maatregelpakketten (zie Deel II hoofdstuk 4).

Deel IV bevat het handelingsperspectief voor het gebruik van een Stroomgebiedsbrede Ecologische SysteemAnalyse. Aan de hand van het pilotproject Groote Molenbeek is in samenwerking met Waterschap Limburg de methode uitgewerkt en toegepast in de praktijk. Dit deel geeft hiervan een kort verslag. 


\section{DEEL I \\ ECOLOGISCHE \\ SLEUTELFACTOREN \\ EN SYSTEEMANALYSE}

$D$ 


\section{ECOLOGISCHE SLEUTELFACTOREN}

\subsection{Inleiding}

In dit hoofdstuk wordt de relatie tussen de Ecologische SleutelFactoren (ESF) en de Stroomgebiedsbrede Ecologische SysteemAnalyse (SESA) uiteengezet. Allereerst wordt een korte samenvatting van de richtinggevende documenten van de STOWA over de ESF-methodiek gegeven. Vervolgens wordt beschreven hoe de ESF-methodiek in de praktijk van het waterbeheer wordt toegepast. Dit gebeurt op basis een aantal ESF-watersysteemanalyses. Deze zijn speciaal voor dit doel door de waterbeheerders aangeleverd (anno 2020), omdat deze als het meest representatief worden beschouwd. Tenslotte wordt de Stroomgebiedsbrede Ecologische SysteemAnalyse (SESA) methodiek geïntroduceerd. De SESA-methodiek wordt in Deel II en III gedetailleerd uitgewerkt.

Hoe de SESA voortbouwt op de ESF-methodiek wordt in figuur 1.1 geïllustreerd.

\section{FIGUUR 1.1}

De samenhang tussen de Ecologische SleutelFactoren (ESF) en de Stroomgebiedsbrede Ecologische SysteemAnalyse (SESA) methodieken. De ESF-methodiek (zwart) richt zich op de toestand van factoren in het waterlichaam. De SESA-methodiek (groen) richt zich op de bronnen, routes en effecten van factoren op aquatische ecosystemen.

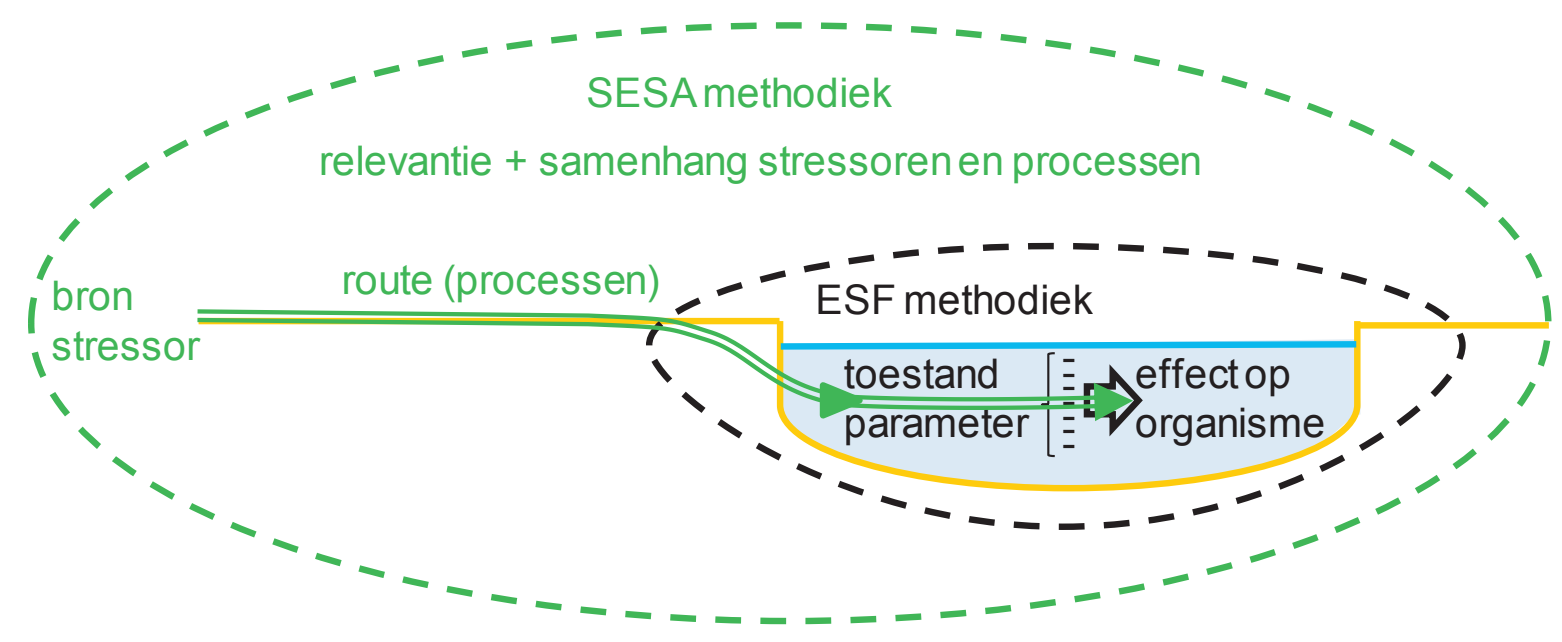

\subsection{Ecologische sleutelfactoren en ecosysteemtoestanden}

\subsubsection{De methodiek van de ecologische sleutelfactoren}

Een ecologische systeemanalyse beoogt het inzicht in de structuur en het ecologisch functioneren van aquatische ecosystemen te vergroten. Om dit inzicht te operationaliseren is door STOWA de ESF-methodiek geïntroduceerd voor stilstaande en stromende wateren. Deze methodiek biedt een handvat voor het uitvoeren van een gestructureerde watersysteemanalyse (STOWA 2014; Schep \& Verbeek 2018), het ontsluit kennis (tools) en het is een methodiek die toepasbaar is voor communicatieve doeleinden. De methode omvat respectievelijk negen (stilstaand water) en tien (stromend water) ecologische sleutelfactoren, waarvan iedere factor refereert aan een voorwaarde voor een goede ecologische toestand. Met de ESF-methodiek wordt de toestand van het aquatische ecosysteem per ESF beoordeeld, met als doel om uiteindelijk een oordeel te geven over het totaal van alle ESF-en. Iedere ESF omvat een aantal gerelateerde parameters. De redenering achter de parameterkeuze en de uiteindelijke invulling van de ESF-methodiek verschilt tussen de stilstaande en stromende wateren. 
Het uitgangspunt voor stilstaande wateren is de relatie tussen de (kritische) nutriëntenbelasting en de ontwikkeling van ondergedoken waterplanten, gebaseerd op de schematisering van de modellen PCLake en PCDitch. Dit uitgangspunt is in drie ESF-en uitgewerkt: externe P- en N-belasting (ESF1: productiviteit water), helderheid (ESF2: licht) en interne P-belasting vanuit de waterbodem (ESF3: productiviteit bodem). De vierde ESF (ESF4: habitatgeschiktheid) gaat uit van het streven naar areaal voor water- en oeverplanten, de vijfde ESF (ESF5: connectiviteit) naar verspreiding van soorten (vooral vispasseerbaarheid), de zesde ESF naar maaibeheer, baggeren en graasdruk (ESF6: verwijdering), de zevende ESF (ESF7: organische belasting) naar puntbronnen van organische belasting en zuurstofhuishouding en de achtste ESF naar toxische belasting (ESF8: toxiciteit). De negende is een sleutelfactor die de afweging tussen functies van watersystemen omvat (ESF9: context) en betreft de haalbaarheid van maatregelen.

Bij ieder van de eerste acht ESF-en kan, ter vergelijking met de respectievelijke ESF, ook gekeken worden naar de milieu-indicatie van de aanwezige plantensoorten. Daarnaast gaat de systematiek uit van een volgordelijkheid, waarbij ESF1-2-3 gaan over basisvoorwaarden voor het voorkomen van ondergedoken waterplanten, ESF4-5-6 over aanvullende voorwaarden voor specifieke soortgroepen en ESF7-8 over specifieke omstandigheden. Sleutelfactor 9 (SF9) gaat over de afweging tussen functies van watersystemen. In de uitvoering van de ESF-methodiek voor de stilstaande wateren worden de ESF-en grotendeels afzonderlijk beschreven, maar bestaat een grote overlap tussen de gehanteerde parameters per ESF.

In de ESF-methodiek stilstaande wateren lijkt productiviteit bovengeschikt gemaakt aan alle andere ESF-en (heterogeniteit, dispersie/connectiviteit, beheer \& onderhoud, organisch belasting en toxiciteit). De methodiek gaat er van uit dat voor het ecologisch functioneren van een stilstaand water vooral de eerste drie sleutelfactoren relevant zijn. Hierbij staat de terugkeer van ondergedoken waterplanten, oftewel de overgang van een algen-gedomineerde situatie naar een begroeiing met waterplanten, centraal. Voor veel wateren is dat een eerste stap naar het herstel van de water- en ecologische kwaliteit in bredere zin. In deze methode is daarmee de focus gelegd op de 'ecologie van de waterkolom', gebaseerd op de werking van voedselwebben in meren en plassen.

Het uitgangspunt voor de ESF-methodiek stromende wateren is gericht op de ecologische toestand in de watergang, waar vier ESF-en als basisvoorwaarden gelden: de wisselingen in afvoer, waterpeil en droogval (ESF1 grondwater en ESF2 afvoerdynamiek), de mate van barrièrewerking van stuwen en planten op de stroming (ESF3 stagnatie) en de vorm van het dwarsprofiel (ESF4 natte doorsnede). De volgende drie ESF-en gelden als aanvullende voorwaarden: verbinding voor vissen, macrofauna en macrofyten (ESF5 connectiviteit), het effect van de oevervegetatie, zoals beschaduwing, droogval, stroming en nutriënten, op het waterlichaam (ESF6 bufferzone) en de ontwikkeling van waterplanten in het waterlichaam (ESF7 waterplanten). Tenslotte worden de ESF-en organische belasting (ESF8 belasting) en vooral de puntbronnen, de toxische belasting (ESF9 toxiciteit) en context (SF10 context) als specifieke omstandigheden gekarakteriseerd. Bij stromende wateren wordt in aanzet gebruik gemaakt van verschillende typen stromend water, van twee ruimtelijke schaalniveaus (stroomgebied en traject) en worden de vissen, macrofauna en macrofyten betrokken. In de volgordelijkheid van factoren in de stromende wateren wordt de hydromorfologie als basisvoorwaarde beschouwd.

In de methodiek voor beide systemen (stilstaand en stromend) worden de ESF-en afzonderlijk beschreven en genormeerd. Vanuit de methodiek van de ESF-en zijn parametergroepen, classificaties naar ecologisch effect en ondersteunende tools ontwikkeld, verdeeld in drie detailniveaus: quickscan, globale analyse en nadere analyse. De ESF-en zijn waterschapsbreed bekend en worden veelvuldig ingezet.

\subsubsection{De toepassing van Ecologische SleutelFactoren (ESF) in de praktijk}

Veel van wat in de aanzet is beschreven blijkt in praktijksituaties slechts beperkt te worden toegepast. Het gebruik van de ESF-en in de praktijk hangt af van de beschikbaarheid en bruikbaarheid van data. De verschillen tussen waterbeheerders in de wijze waarop de parameterkeuze plaatsvindt en de toepassing ervan zijn groot.

In de voorbeelden van 'best uitgevoerde' ESF-analyses voor stilstaande wateren, verkregen van acht waterbeheerders met de mededeling dat de aangeleverde voorbeeld-ESF -analyses het meest representatief zijn voor iedere andere analyse in 
het betreffende beheergebied (oplopend tot een maximum van 90 voor een waterbeheerder), blijkt dat van de circa 49 in de verschillende ESF-handleidingen opgevoerde factoren er gemiddeld maar 12-51\% daadwerkelijk ingezet worden. Voor stromende wateren ( $\mathrm{n}=4$, ook hierbij zijn de meeste representatief voor iedere analyse in het beheergebied van de desbetreffende waterbeheerder) is dat $11-62 \%$ van de circa 61 voorgestelde ESF-en.

Feitelijk worden alleen die parameters gebruikt die voldoende frequent zijn gemonitord, voornamelijk zuurstofloosheid, droogval, totaal fosfaat, stroomsnelheid, verblijftijd, doorzicht, taludhelling en maaifrequentie. Analyses van veel waterbodem-, habitat-, omgevings- en stroomgebiedsparameters blijven veelal achterwege. Verder is van integratie van parameters nauwelijks sprake. Ook blijkt dat de ESF-toepassingen voor stromende wateren veel minder eenduidig zijn dan die voor stilstaande wateren. Zo is bijvoorbeeld de volgordelijkheid van factoren gewijzigd en worden verschillende naamgevingen door elkaar gebruikt.

Bij de toepassing van de set ESF-en voor stilstaande wateren ligt de focus van de waterbeheerder, naast op vispassages, bijna volledig op de aanwezige vegetatie, omdat er in de toepassing van uit gegaan wordt 1.) dat een soortenrijke vegetatie duidt op een goede ecologische toestand, 2.) dat ondergedoken vegetatie ruimte geeft aan tal van andere soortgroepen, zoals vissen en macrofauna, en 3.) dat als de migratiemogelijkheden en de toestand voor vis op orde zijn andere organismen (macrofyten, macrofauna) geen connectiviteitsproblemen ondervinden. Op deze drie aannames gaan niet in alle situaties op en omvatten daarnaast niet de kern van het systeem functioneren. Er is dus een duidelijk verschil tussen het doel van de ESF-benadering, een handvat bieden voor systeemanalyse, en de toepassing in de watersysteemanalyses in de praktijk.

In de toepassing van de ESF stilstaande wateren en stromende wateren richt de analyse zich vooral op de abiotische en in mindere mate de biotische toestand van het waterlichaam. De per ESF verzamelde informatie, ook die afkomstig uit externe bronnen, zoals agrarisch landgebruik, wordt ingezet om de interne situatie in het water te beoordelen. De daadwerkelijk door waterbeheerders gebruikte parameters zijn veelal de parameters die standaard in de monitoring worden gemeten. Daarmee richt de ESF-methode en de bijhorende beschrijvingen van ecosysteemtoestanden zich vooral op de waterkolom binnen het aquatisch ecosysteem en niet op de in veel gevallen overheersende invloed van de oeverzone (litoraal) of de waterbodem op het functioneren van ondiepe stilstaande wateren. Uitzondering hierop is fosfaat nalevering. In de aanpak en vastgestelde grenswaarden voor stilstaande wateren speelt de overgang van de troebele/algen-fase naar een heldere/waterplanten-fase een beslissende rol als criterium of een parameter als knelpunt wordt gezien. Het bereiken van de aanwezigheid van waterplanten betekent echter niet dat de benodigde ecologische kwaliteit is behaald. Deze eenzijdige focus op waterplanten geldt niet voor de ESF stromende wateren, waar naast waterplanten ook andere organismegroepen aan de orde komen.

Kort samengevat worden met de ESF-en de afzonderlijke knelpunten in het waterlichaam in beeld gebracht. Per parameter of groep van parameters groep zijn daarvoor grenswaarden gekozen. De grenswaarden zijn soms in de betreffende tools vastgelegd, maar kunnen ook door de gebruiker zijn gedefinieerd. Grenswaarden die de toestanden 'goed' en 'niet goed' ( 2 klassen) beschrijven tot opdelingen in meer klassen, zoals 5 klassen conform de KRW-beoordelingsklassen en soms zelfs 7 klassen worden ook gebruikt. Opvallend is dat de getalswaarden van de grenzen vaak voor alle stilstaande watertypen gelijk zijn, waarmee het functioneren van bijvoorbeeld een meer en een sloot gelijk gesteld worden. Voor de stromende watertypen is dit minder variabel; de klassen zijn meestal gekoppeld aan de 5 KRW-kwaliteitsklassen, bijvoorbeeld indien er twee klassen onderscheiden worden refereert de grenswaarde naar de scheiding tussen de KRW-klassen 'matig' en 'goed'. De KRW-achtige beoordeling berust daarmee op de gekozen klassengrenzen, m.a.w. er wordt vanuit gegaan dat alle watertypen binnen de stromende wateren en soms zelfs alle wateren in Nederland op dezelfde abiotische grenzen kunnen worden ingedeeld. Deze wijze van omgaan met factoren is geen gevolg van beperkte tijd en middelen, maar een gevolg van de statische wijze waarop de ESF-en zijn ingevuld terwijl grenswaarden voor factoren per watertype sterk kunnen verschillen. 
Naast de ESF-en zijn ook ecosysteemtoestanden beschreven. In een ESF-analyse wordt onderscheid gemaakt tussen een analyse met de ecologische toestand als uitgangspunt en een analyse vanuit de randvoorwaarden. Voor de tweede benaderingswijze zijn de ESF-en ontwikkeld. De ESF-analyse richt zich primair op robuuste meetbare verschillen in de toestanden waarin ecosystemen zich kunnen bevinden en veel minder op de meer subtiele kleinere variaties binnen een toestand in tijd en ruimte. Voor de ecologische toestand, omschreven als de toestand waarin een systeem zich op een bepaald moment in de tijd en een bepaalde plaats daadwerkelijk bevindt (zowel wat betreft milieufactoren als wat betreft soorten) zijn 'grove' en statische beschrijvingen gemaakt. Deze beschrijvingen weerspiegelen de veldtoestand en zijn bedoeld om aan te geven hoe en wanneer toestanden veranderen, welke parameter(s) hiervoor het meest sturend is/zijn en hoe groot de verandering in parameters moet zijn. Ze zijn ook bedoeld als een visuele ondersteuning voor o.a. bestuurders om de verschillende toestanden van een 'beeld' of 'snapshot' te voorzien.

Voor de stilstaande wateren zijn 27 toestanden onderscheiden, verdeeld over 11 groepen:

- Troebel water met 1.) weinig algen, 2.) groenalgen of 3.) blauwalgen;

- Water met 4.) kroos of 5.) drijfbladplanten;

- Helder water 6.) zonder, 7.) met woekerende waterplanten, of een 8.) gevarieerde ondergedoken waterplantenvegetatie; - Watergang 9.) vol met helofyten, 10.) vol met een monotone vegetatie bedekt met kroos of met 11.) drijfblad- en ondergedoken waterplanten.

Voor stromende wateren is de indeling minder concreet. Wel is er een classificatie opgesteld gebaseerd op de lichtbeschikbaarheid (beschaduwing) en de stromingsenergie (afvoer, verhang, breedte), met 6 klassen gerelateerd aan waterplantenontwikkeling, 1 klasse gerelateerd aan droogval en 2 klassen gerelateerd aan de substraatvariatie.

Deze indelingen wijken sterk af van eerder ecologische indelingen van Nederlandse oppervlaktewateren, zoals de CUWVO-typologie, de EBEO-systemen, de Aquatische Natuurdoeltypen, de CML-typen, enz. en natuurlijk ook de op dit moment gangbare KRW-typologie.

In de praktijk blijken de ESF gerelateerde ecosysteemtoestanden nauwelijks te worden toegepast, terwijl de toestanden feitelijk de integratie zijn van alle ESF-en en de bijhorende biologie. Mogelijk hangt dit samen met het ontbreken van een verband tussen de grenswaarden in de ESF-beoordeling en de beschrijvingen van de ecosysteemtoestanden. 


\section{STROOMGEBIEDSBREDE ECOLOGISCHE SYSTEEMANALYSE}

Het gebruik van de ecologische sleutelfactoren (ESF-en) geeft meer inzicht in de individuele factoren die een rol spelen in het watersysteem en hebben geleid tot een meer uniforme communicatie binnen het Nederlandse waterbeheer. Het onderscheiden van ecosysteemtoestanden draagt verder bij aan die communicatie, omdat ze goed herkenbaar zijn voor beleidsmakers en bestuurders. Wat er echter nog mist in de ESF-systematiek is de rol van de bronnen van stress en de samenhang tussen verschillende componenten van het watersysteem. Daarnaast zijn de ecologische sleutelfactoren niet naar relevantie voor het totale ecosysteem functioneren aangeduid of geordend. Ook zijn ze niet eenduidig gedefinieerd en van ongelijke orde; zo lopen stuur-, sleutel- en stressfactoren bijvoorbeeld door elkaar heen en verschillen de ESF-en tussen stromende en stilstaande wateren. In de hier beschreven stroomgebiedsbrede ecologische systeembenadering vervangen de 5S-en uit het 5S-model (Verdonschot et al. 1995, 1998) daarom de ESF-systematiek. De stroomgebiedsbrede ecologische systeemanalyse (SESA) bouwt hiermee wel voort op de ESF-en, herijkt sommige factoren en voegt de samenhang op landschapsschaal toe. Daarmee komen naast natuurlijke landschappelijke factoren ook de stressoren afkomstig uit de omgeving (de bronnen van stress en hun routes richting waterlichaam) in beeld. Ook wordt de benadering voor stromende en stilstaande wateren met het gebruik van het 5S-model gestroomlijnd.

Wat is een SESA? De term stroomgebied verwijst naar het gebied dat op een waterlichaam afwatert of aan een waterlichaam toelevert, een polder, een polder-boezemsysteem of een andere ruimtelijke (geo)hydrologische eenheid. Voor de leesbaarheid wordt hierna met het woord stroomgebied deze brede omschrijving geduid. Een SESA beoogt het inzicht in de structuur, de samenhang tussen factoren en het ecologisch functioneren van het aquatisch ecosysteem te vergroten. Zowel ruimtelijk, van de grenzen van het stroomgebied tot in de habitat, als temporeel, grofweg van decades tot dagen. Omdat waterlichamen open systemen zijn, die in nauwe samenhang met het landschap functioneren, is niet de oever van een waterlichaam of het dal van een beek de begrenzing van het systeem, maar vormt de waterscheiding de begrenzing. Met deze begrenzing worden de bronnen en transportroutes van stressoren (zoals een fosfaatgift op een akker die via een zandbodem uitspoelt naar een beek en al dan niet onderweg een buffer passeert) die effect hebben in een waterlichaam automatisch onderdeel van het systeem (zie o.a. Hynes 1975, Minshall 1988, Anderson 2014). De benadering omvat ook de hiërarchie in ruimtelijke en temporele schalen die relevant zijn voor de praktijk van het waterbeheer, denk bijvoorbeeld bij een beeksysteem aan stroomgebied, beekdal en beek als drie ruimtelijke schalen.

In een stroomgebiedsbrede ecologische systeembenadering wordt naar alle componenten in en rond (tot aan de stroomgebiedsgrenzen) een oppervlaktewater gekeken, omdat ze allemaal een rol in het functioneren hebben. De directe omgeving en de waterbodem spelen meestal een overheersende rol in het functioneren van onze ondiepe $(<4$ m) oppervlaktewatersystemen (sloten, polen, plassen, ondiepe meren). De verhouding bodemoppervlakte-watervolume is in de meeste Nederlandse oppervlaktewateren zo groot dat beide bepalend zijn voor wat er in de waterkolom gebeurt (Vadeboncoeur et al. 2002, Schindler \& Scheuerell 2002). In de stroomgebiedsbrede ecologische systeembenadering staat niet de waterkolom maar de bodem, het litoraal en de omgeving (het landschap) centraal.

Een belangrijk aspect van de stroomgebiedsbrede ecologische systeembenadering is het meenemen van samenhang tussen factoren. Het woord samenhang verwijst naar het voorkomen van individuen, soorten en gemeenschappen in de multifactoriële milieuruimte. Organismen nemen niet toe of af langs monofactoriële gradiënten, maar zijn afhankelijk van het samenspel van factoren (Verdonschot 1990, Reynolds 1998). De interacties tussen soorten, milieufactoren en soorten en milieufactoren zijn ook niet gelijk, maar bestaan uit dominantieverhoudingen en terugkoppelingsmechanismen (hier aangeduid als hiërarchieën). Dit is bijvoorbeeld in het 5S-model uitgewerkt (Verdonschot et al. 1995, 1998). Het belang van deze verhoudingen en mechanismen zijn op zichzelf ook weer afhankelijk van aanwezige milieu-omstandigheden (Allan \& Starr 1982, Verdonschot et al. 1998). Deze samenhang staat centraal in de SESA en voegt daarmee de zo noodzakelijke integratie toe. Als voorbeeld is de meervoudige samenhang tussen verschillende stressoren en ecologische hoofdsleutelprocessen in stromende wateren weergegeven (Tabel 2.1). 
TABEL 2.1

De multiple samenhang tussen multiple stressoren en ecologische hoofdsleutelprocessen in stromende watersystemen over drie schalen.

\begin{tabular}{|c|c|c|c|c|c|c|c|c|c|c|c|}
\hline 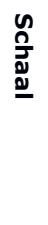 & $\begin{array}{l}\text { Ecologische } \\
\text { sleutelfactoren }\end{array}$ & 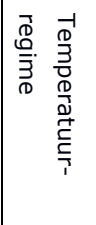 & 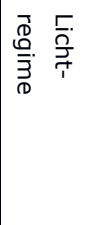 & 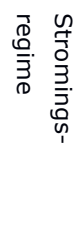 & 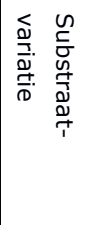 & 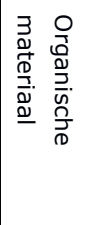 & 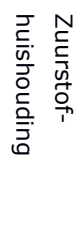 & 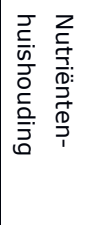 & 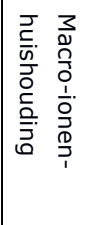 & 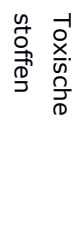 & 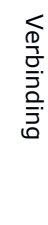 \\
\hline \multirow{5}{*}{$\begin{array}{l}0 \\
\frac{1}{1} \\
0 \\
0 \\
\vdots \\
0 \\
0 \\
\frac{0}{0} \\
\frac{0}{2}\end{array}$} & $\begin{array}{l}\text { Geohydrologische } \\
\text { stress }\end{array}$ & & & & & & & & & & \\
\hline & $\begin{array}{l}\text { Geomorfologische } \\
\text { stress }\end{array}$ & & & & & & & & & & \\
\hline & $\begin{array}{l}\text { Geochemische } \\
\text { stress }\end{array}$ & & & & & & & & & & \\
\hline & $\begin{array}{l}\text { Chemische stress } \\
\text { diffuse bronnen }\end{array}$ & & & & & & & & & & \\
\hline & $\begin{array}{l}\text { Stress } \\
\text { puntbronnen }\end{array}$ & & & & & & & & & & \\
\hline \multirow{3}{*}{ 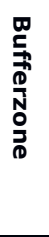 } & $\begin{array}{l}\text { Hydrologische } \\
\text { stress }\end{array}$ & & & & & & & & & & \\
\hline & $\begin{array}{l}\text { Morfologische } \\
\text { stress }\end{array}$ & & & & & & & & & & \\
\hline & $\begin{array}{l}\text { Chemische stress } \\
\text { diffuse bronnen }\end{array}$ & & & & & & & & & & \\
\hline \multirow{4}{*}{ 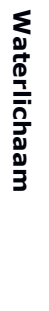 } & $\begin{array}{l}\text { Fysische stress } \\
\text { (systeem) }\end{array}$ & & & & & & & & & & \\
\hline & $\begin{array}{l}\text { Hydraulische } \\
\text { stress }\end{array}$ & & & & & & & & & & \\
\hline & $\begin{array}{l}\text { Morfologische } \\
\text { stress }\end{array}$ & & & & & & & & & & \\
\hline & $\begin{array}{l}\text { Stress beheer } \\
\text { en onderhoud }\end{array}$ & & & & & & & & & & \\
\hline
\end{tabular}

De stroomgebiedsbrede ecologische systeembenadering kijkt niet naar factoren als statische gegevens, maar beschouwt het functioneren van ecosystemen als dynamisch. Factoren en hun samenhang zijn namelijk een gevolg van processen die in de tijd veranderlijk zijn. Met deze temporele aspecten moet bij een analyse steeds rekening worden gehouden.

Een SESA wordt uitgevoerd om de oorzaken van stressoren in het waterlichaam op te sporen, om vervolgens maatregelen te kunnen nemen specifiek gericht op het wegnemen van deze oorzaken. De meeste, maar zeker niet alle, oorzaken van stress ontstaan buiten het waterlichaam en hebben een combinatie aan stressoren in het waterlichaam tot gevolg. Dit wordt aangeduid als 'multiple stress'. Lange tijd werd de aandacht gericht op zuurstofloosheid door organische belasting, op overmaat aan fosfaat door eutrofiëring of op verlies van stroomsnelheid door kanalisatie. Steeds werden de aandacht en de maatregelen gericht op enkelvoudige stressoren en werden maatregelen voor de betreffende stressor ingezet, zoals respectievelijk een RWZI verbeteren, fosforbelasting terugdringen door isoleren, baggeren of bevissen, de beek hermeanderen of het gebruik van gifstoffen reguleren. Echter komen in de praktijk de meeste stressoren niet alleen voor, maar werken in combinatie in op het waterecosysteem. Agrarisch landgebruik leidt bijvoorbeeld tot beekkanalisatie, kappen van beekbegeleidend bos, bemesting en het gebruik van bestrijdingsmiddelen met af- en uitspoeling van nutriënten en gifstoffen. Hierbij is sprake van een multiple stress situatie die vaak op een grotere ruimtelijke schaal invloed heeft dan een locatie of traject. In Nederlandse oppervlaktewateren is bijna altijd sprake van multiple stress, soms door één en vaak door meerdere oorzaken buiten het waterlichaam. 
In dit document wordt een stap gezet op weg naar een SESA. Hiervoor wordt de kennis van de samenhang en interacties tussen factoren die bepalen wanneer de werking en de effecten van multiple stressoren relevant zijn (negatieve gevolgen hebben) vereenvoudigd. Ook wordt de kennis van de oorzaak-gevolg ketens, m.a.w. van de bronnen/oorzaken en transportroutes (in brede zin van het woord), van multiple stressoren en multiple biologische responsen zo eenvoudig mogelijk gemaakt en geoperationaliseerd. Kennis van deze ketens geeft gelijktijdig inzicht in de aard van de te nemen maatregelen en de plaats waar de meest effectieve maatregel of maatregelpakket kan worden ingezet.

Samenvattend beoogt een SESA de multiple stressoren in een stroomgebied in beeld te brengen en handvatten te bieden ze effectief aan te pakken. Daarom speelt de systeemanalyse zich af over meerdere ruimtelijke en temporele schalen om zo inzicht in samenhangende hiërarchische relaties tussen factoren over schalen te vergaren en daarmee een zo groot mogelijke integraliteit te bereiken. Tegelijk wordt daarin het belang van de sociaaleconomische context (vaak aangeduid als de $6^{\text {de }} S$ in het 5S-model) geïmplementeerd. Door de expliciete positie van de temporele schaal in het 5S-model krijgen processen en natuurlijke dynamiek in ecosystemen een positie. De factor tijd speelt een cruciale rol in elke vorm van ecologische systeemanalyse.

Om de meest effectieve maatregelen op de juiste schaal in ruimte en tijd te nemen is een hiërarchisch (in termen van dominanties en terugkoppelingen) geordend overzicht nodig van de belangrijkste sturende factoren, functies en interacties in een ecosysteem. Het 5S-model biedt dit hiërarchisch overzicht, is transparant, voorkomt doublures en is in de praktijk gemakkelijk hanteerbaar getuige de toepassing op een breed scala aan ecosystemen. Zo is het model toegepast in, onder andere, beken, sloten, meren, moerassen en recent koraalriffen.

\section{FIGUUR 2.1}

Voorbeeld van de doorwerking van veranderingen in het landgebruik via stressoren op de ecologische sleutelfactoren die direct verantwoordelijk zijn voor de verandering en de macrofaunagemeenschap ( $\mathrm{mf}$ = macrofauna indicatie) over verschillende schalen. Noot: de ESF-en spelen zich voornamelijk af in de laag van stressoren als statische factoren, terwijl hier dynamische processen worden afgebeeld.
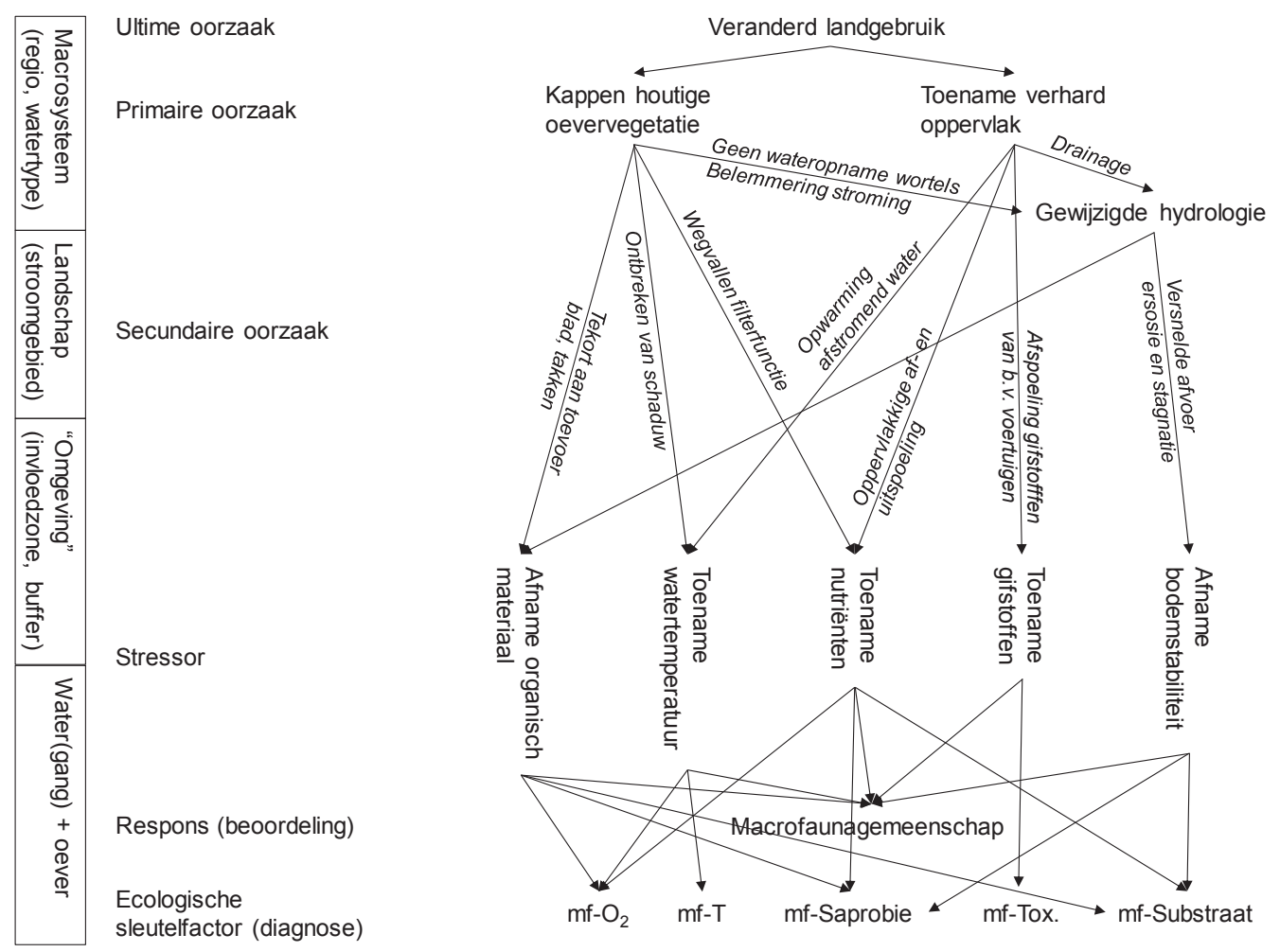
Door de focus te verleggen van het waterlichaam naar het 'hydrologisch landschap' waar het waterlichaam deel van uitmaakt is het vaststellen van oorzaak-effect relaties/ketens beter mogelijk, mede doordat naar en over meerdere schalen wordt gekeken. In het 'hydrologisch landschap' wordt de externe omgeving onderdeel van het watersysteem, waardoor de samenhang van stressoren en responsen ook een logisch verband krijgen (Figuur 2.1). Door het kijken naar het 'hydrologisch landschap' komt ook de sociaaleconomische context, oftewel de menselijke activiteiten, duidelijk in beeld. Een context die met technieken, zoals een Ecomindmap, direct linken aan de schalen en factoren in het 5S-model.

Omdat de geografische en typologische context het uitgangspunt is in de systeemvoorwaarden van het 5S-model vormen regionale differentiatie en typologische verschillen de basis waarbinnen een SESA plaatsvindt. M.a.w. ecosysteemtoestanden hangen samen met deze geografische en typologische randvoorwaarden waarbinnen de verschillende natuurlijke aquatische gemeenschappen voorkomen. Ecosysteemtoestanden kunnen niet op alleen visuele kenmerken worden gebaseerd. Ze moeten daadwerkelijk functionerende ecosystemen representeren, moeten dynamiek in factoren en soortensamenstelling afdekken en moeten voldoende gedetailleerd zijn om ook in de praktijk bruikbaar te zijn. 


\section{DEEL II \\ ECOLOGISCHE SYSTEEMANALYSE}

\section{$\rightarrow$}




\section{AANPAK ECOLOGISCHE SYSTEEMANALYSE}

\subsection{Inleiding}

De doelen van dit hoofdstuk zijn: 1.) het gekwantificeerd in beeld brengen van de bron van iedere stressor en de wijze waarop die bijdraagt aan een kwaliteitsverslechtering van een ontvangend oppervlaktewater, 2.) het uitwerken van de relevantie van (hiërarchie), de samenhang tussen (integraliteit en multiple stress) en de veranderingen in de tijd (processen) van en tussen geschaalde ecologische (sleutel)factoren, en 3.) de wijze waarop bij verstoring door stressfactoren gestuurd kan worden op de ecosysteemtoestanden door het veranderen van complexen van geschaalde stuurfactoren.

Om het ecologisch handelingsperspectief van de waterbeheerder verder te ontwikkelen en te concretiseren is het noodzakelijk de bouwstenen van de ecologische systeemanalyse, zoals sleutelfactoren, stuurfactoren, ecosysteemtoestanden, meervoudige of multiple stress, maatregelen en monitoring duidelijk te definiëren, met elkaar in verband te brengen en van een onderbouwde wetenschappelijke grondslag te voorzien.

KADER: ENKELE BELANGRIJKE TERMEN (ZIE ONDER MEER VERDONSCHOT ET AL. 2015):

- Ecologische sleutelfactoren zijn factoren die directe voorwaarden zijn voor organismen om voor te kunnen komen (zie ook Whittaker 1978, Austin 1980, Austin \& Smith 1990). Ecologische sleutelfactoren worden ook aangeduid als oorzakelijke, operationele of directe factoren.

Ecologische stuurfactoren, in het kort stuurfactoren, zijn factoren in het waterecosysteem die direct door beheer en inrichting oftewel de waterbeheerder kunnen worden gestuurd en die indirect inwerken op organismen. Ecologische stuurfactoren vormen een deel van de indirecte of conditionerende factoren, factoren die indirect op het voorkomen van organismen inwerken.

- Ecologische stressfactoren, in het kort stressoren, zijn de factoren die door menselijke activiteiten stress uitoefenen op het waterecosysteem (cf. verstoring naar Pickett \& White 1985).

- Ecologische responsfactoren, in het kort responsfactoren, zijn biologische factoren of organismen (soorten, gemeenschappen, ecosystemen) die reageren op de abiotische milieufactoren.

- Abiotische milieufactoren zijn (voor organismen externe) milieufactoren die geen biologische oorsprong hebben in tegenstelling tot biotische factoren.

- Ecologisch functioneren is de werking van het waterecosysteem wat een gevolg is van de rollen (functies) die soorten spelen en de abiotische en biotische processen die plaats vinden (zie ook Jax 2005, Farnsworth et al. 2017).

- Ecologische of ecosysteemtoestand is de resultante van het ecologisch functioneren op een moment in de tijd.

De systematiek van de Ecologische Sleutelfactoren (ESF) is door STOWA omschreven als het palet aan factoren die samen inzicht geven in de omstandigheden (voorwaarden) die de ecologische toestand van een watersysteem verklaren of bepalen (STOWA 2014). De sleutelfactoren bieden duidelijke handvatten voor de waterbeheerders. Ze zijn echter nog niet uitontwikkeld. De ervaringen met de toepassing en de kennis die via dit project wordt ontsloten zal aanleiding kunnen zijn voor een verbetering van de ESF systematiek. Daarbij is het belangrijk dat 1.) de hiërarchie in het ecologisch belang van factoren goed naar voren komt, 2.) de invloed van ruimtelijke en temporele schalen op de invloed van factoren en effectiviteit van maatregelen duidelijk belicht wordt, en 3.) de samenhang tussen factoren en de ecologische noodzaak van een integrale aanpak in de uitwerkingen benadrukt wordt.

In de ecologische systeemanalyse staat het zoeken naar de bronnen of oorzaken van een probleem centraal. De ecologische systeemanalyse werkt niet met complexe, vaak mechanistische, relatieschema's maar koppelt oorzaak (de bron van stress) aan effect, namelijk de respons van de biologie (o.a. Allan et al. 1997, Sponseller et al. 2001, Fraterrigo \& Downing 2008). De methode identificeert, kwalificeert, kwantificeert en combineert de bronnen van stress en vergelijkt die met de responskenmerken van de aanwezige organismen om vervolgens gecombineerde, doelgerichte maatregelpakketten te 
selecteren. De achterliggende kennis van de vele schijven waarlangs processen verlopen is wetenschappelijk van groot belang, maar is voor de praktische toepassing niet direct nodig. Daarom wordt die achterliggende kennis in de ecologische systeemanalyse wel gebruikt om relaties tussen oorzaak en gevolg te leggen, maar niet getoond in de toepassing.

Het doel van een ecologische systeemanalyse is het duiden van de stressoren die effect hebben op het aquatisch ecosysteem over verschillende schalen in ruimte (traject-stroomgebied) en tijd (uren-jaren). Daarnaast heeft het als doel oplossingsrichtingen aan te geven (maatregelpakketten). De stressoren worden gekwantificeerd in termen van de mate van stress over verschillende schalen in ruimte en tijd en uiteindelijk gekoppeld aan de maatregelpakketten.

In de voorgestelde ecologische systeembenadering wordt gedacht en gewerkt vanuit het ecosysteem in de richting van het menselijk handelen. Tot op heden was deze redenatie precies omgekeerd. Deze ommekeer ligt in de lijn van het denken over duurzame, robuuste systemen en het werken vanuit de natuurlijke processen die bij het ecosysteem horen. Nemen we een meer als voorbeeld, dan kijken we naar hoe het ecosysteem functioneert en welke factoren daarbij belangrijk zijn. Dit zijn bijvoorbeeld het ontbreken van een brede oever- en moeraszone, het ontbreken van natuurlijke peilfluctuaties, het teveel aan voedingsstoffen en het gebrek aan habitatheterogeniteit. Deze factoren worden gekwantificeerd en er wordt naar de omgeving gekeken om te duiden waar de individuele stressoren, of combinaties van stressoren vandaan komen en welke acties daarop nodig zijn om ze terug te dringen tot een voor het ecosysteem acceptabel niveau.

Om de ecologische relevantie van het vaak grote aantal factoren te kunnen duiden is kennis nodig van:

- De factor of range van waarden binnen de factor die ecologisch van belang zijn of die stress opleveren.

- Het gewicht van de factor in termen van de impact (hiërarchische positie van de factor in ruimte en tijd).

De rol van de factor in het ecologisch functioneren van het ecosysteem en het voorkomen van soorten.

Het is belangrijk te beseffen dat ecosystemen afgebakende geografische eenheden zijn op basis van de samenhang in processen. In feite is ieder ecosysteem hierdoor weer onderdeel van een groter ecosysteem, afhankelijk van de schaal waarop gekeken wordt. Grootschalige, lange-termijn processen hebben systemen gevormd en bepalen nog steeds in hoge mate de werking van ecosystemen. Dit worden de systeemvoorwaarden genoemd. Door de mens gemaakte systemen zijn weliswaar niet op natuurlijke wijze gevormd, maar zijn wel degelijk onderhevig aan de grootschalige, lange-termijn processen die ook natuurlijke systemen vormen. Om systemen duurzaam en robuust in te richten of te ontwikkelen moeten daarom de grootschalige, lange-termijn processen altijd in acht worden genomen.

Het ecosysteem zelf functioneert onder de huidige heersende hydrologische, morfologische en fysisch-chemische omstandigheden. Ieder van deze onderdelen, de hoofdgroepen hydrologie (stroming), morfologie (structuren) en chemie (stoffen) omvat een groep factoren, een factorcomplex, met daarbinnen weer een hiërarchie in belang en een verschil in schaal waarop factoren opereren. Voor aquatische systemen geldt dat, in grote lijnen, de hydrologie domineert, die vervolgens de morfologie vormt en de chemie bepaalt, behalve wanneer parameters door externe oorzaken extreme waarden (zoals hoge fosforbelasting of gifstoffen) aannemen (Birk et al. 2020).

De organismen of soorten die voorkomen in het betreffende aquatische systeem zijn de respons op de samenhang en werking tussen de systeemvoorwaarden, de hydrologie, de morfologie en de chemie. Daarnaast reageren ze ook op elkaar, via mechanismen als dominantieverhoudingen en positieve en negatieve terugkoppelingen.

Om deze complexe samenhang en werking van factoren en soorten te vereenvoudigen is het 5-S-model ontwikkeld (Verdonschot et al. 1998), waarin de complexiteit van het functioneren van een aquatisch ecosysteem hanteerbaar is gemaakt. Voor een gedetailleerde uitleg van het 5-S-model wordt naar deel II verwezen.

De mens heeft op allerlei manieren veranderingen aangebracht in aquatische ecosystemen, soms in de systeemvoorwaarden en in veel gevallen in de hydrologie (bijv. peilbeheer), morfologie (bijv. beekkanalisatie en -normalisatie), chemie (bijv. eutrofiering, organische belasting) en soorten (bijv.introductievan soorten). Het menselijk handelen is dus onderdeelvan de 5-S-en. 
De kern van de ecologische systeemanalyse is dat gebruik wordt gemaakt van vereenvoudigde relaties tussen de veroorzakers van stress, de stressfactoren (stressoren), het gevolg of effect (veranderde milieufactoren of respons in de biologie) en de reactie van de mens in de vorm van het nemen van maatregelen (antropogene respons). Een voorbeeld van een dergelijke keten tussen de menselijke activiteiten en het ecosysteem is de DPSIR-keten (EEA 1995). Deze keten is later uitgebreid tot de DPSIRR-keten (Feld et al. 2011). DPSIRR staat voor: Driving forces (=menselijke activiteiten) - Pressures/Stressors (=drukfactoren) - State (=toestand van ecosysteem) - Impact (=gevolgen voor het ecosysteem (functioneren) en ecosysteemdiensten) - Responses (=menselijke reactie in de vorm van maatregelen) - Recovery (=herstel van het ecosysteem). Op basis van de DPSIRR-keten- benadering is de samenhang en werking tussen de factoren en processen voor allerlei problemen in interactieschema's uitgewerkt. Hierin zijn vaak ook de aangrijpingspunten van menselijk handelen en de daaruit volgende keten van effecten aangegeven.

Samenvattend gaat de ecologische systeemanalyse uit van drie basisconcepten (Figuur 3.1):

1. De factoren geordend naar het 5-S-model: Systeemvoorwaarden, Stroming, Structuren, Stoffen en Soorten (incl. menselijk handelen).

2. De relevante ruimtelijke en temporele schalen met hun hiërarchie en de ecologische filters die het voorkomen van organismen bepalen.

3. De vereenvoudigde stressor-gevolg-respons interacties.

\section{FIGUUR 3.1}

De vereenvoudigde oorzaak-gevolg-keten die bij de ecologische systeemanalyse wordt toegepast en kijkt naar de 5 hoofdgroepen van factoren (5S-en) over meerdere schalen in ruimte en tijd.
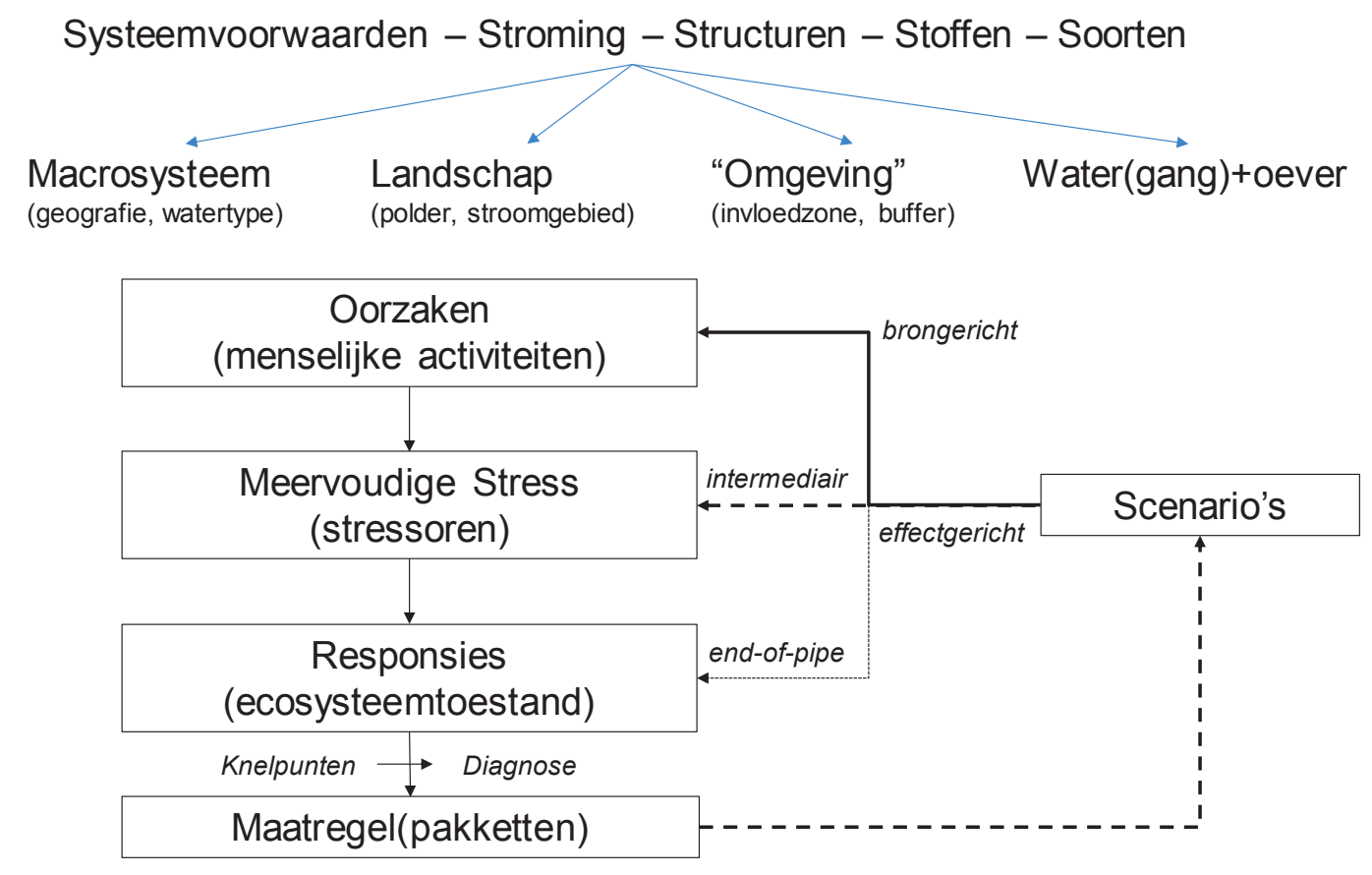


\subsection{Algemene werkwijze}

Om het ecologisch functioneren van een stroomgebied, polder of hydrologische eenheid te doorgronden, in termen van de toestand waarin het systeem verkeert en de processen die spelen, worden in de methodiek van ecologische systeemanalyse vier hoofdvragen in kwantitatieve termen beantwoord (Verdonschot 2016; Figuur 3.2):

\section{Hoe zit het macrosysteem in elkaar?}

Het macrosysteem is de ecologische systeemcontext van de te bestuderen hydrologische eenheid. Het bakent het watersysteem af, het typeert het en geeft de natuurlijke randvoorwaarden aan op macroschaal.

1. Het geografisch/ruimtelijk afbakenen van het onderzoeksgebied, het indelen in deelgebieden en het typeren van het (oorspronkelijk) waterlichaam en opdelen naar werkbare eenheden.

2. Het beschrijven van de relevante systeemvoorwaarden, de irreversibele veranderingen en het natuurlijk macrosysteem functioneren.

2. Wat is de ecosysteemtoestand en hoe functioneert het ecosysteem?

3. Het vaststellen van de huidige toestand van het ecosysteem in termen van soorten/gemeenschappen en milieufactoren.

4. Het beschrijven van het huidig ecosysteem functioneren.

3 Welke abiotische stressoren spelen er en wat is de biologische respons?

5. Het identificeren van stressoren en het bepalen van de mate van abiotische en biotische stress.

6. Het vergelijken van de mate van abiotische stress met de biologische respons.

4. Wat zijn de relevante maatregelpakketten en scenario's?

7. Het in globale termen beschrijven het gewenste streefbeeld.

8. Het samenstellen van maatregelpakketten en het uitvoeren van scenario-analyses.

\section{FIGUUR 3.2}

De vier kernonderdelen in een ecologische systeemanalyse.

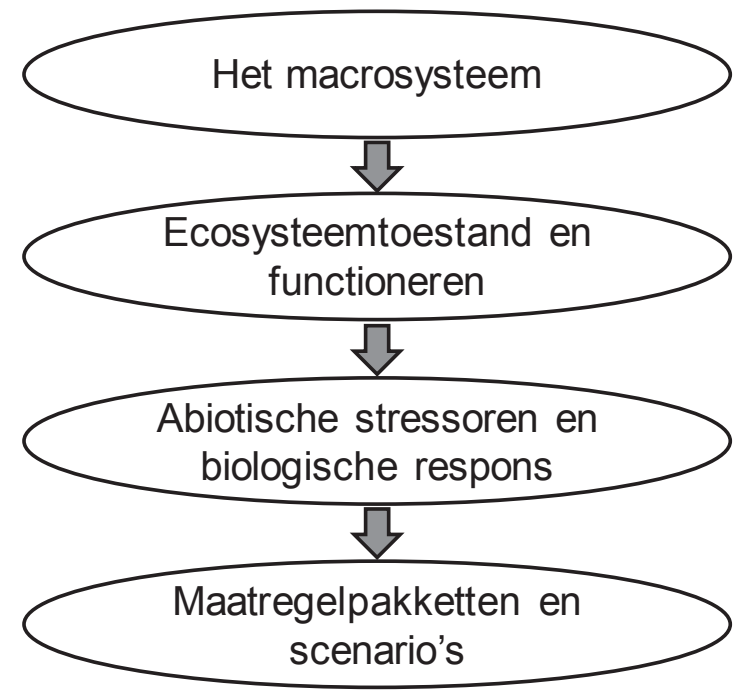




\section{HET MACROSYSTEEM}

\subsection{Geografische (ruimtelijke) afbakening en typering}

\subsubsection{Ruimtelijke afbakening}

Voor een ecologische systeemanalyse wordt een hydrologische eenheid, een stroomgebied of polder geïdentificeerd en opgedeeld in ruimtelijke eenheden of compartimenten (Figuur 4.1):

- Hydrologische ruimtelijke eenheid, zoals het afwateringsgebied, zijstroomgebied of (deel)polder, dat afwatert op het hoofdwaterlichaam, zoals een watergang, beek, sloot of boezem.

- Hoofdwaterlichaam, zoals een beek, boezem, meer of sloot/slotencomplex.

- Segment, deel van het hoofdwaterlichaam. Hierbij hoort impliciet de naastgelegen bufferzone, zoals een beekdalzone, zone langs boezem of randzone van een meer.

De ruimtelijke begrenzing van de eenheid is (bij voorkeur) gebaseerd op de systeemvoorwaarden, met zo veel mogelijk samenhang in de geohydrologie, geomorfologie en geochemie van het macrosysteem die op een grotere tijdschaal standhoudt. Hoe meer de ruimtelijke begrenzing samenvalt met het grootschalig, lange-termijn functioneren van een afwateringsgebied, hoe makkelijker later passende (passend in het grootschalig functioneren), duurzame en logische maatregelen bepaald kunnen worden die leiden tot een robuust systeem.

\section{FIGUUR 4.1}

De onderverdeling van ruimtelijke eenheden voor drie hoofdwatertypen t.b.v. een ecologische systeemanalyse: een stroomgebied van een beek (links boven), een polder (rechts boven) en een meer (onder).
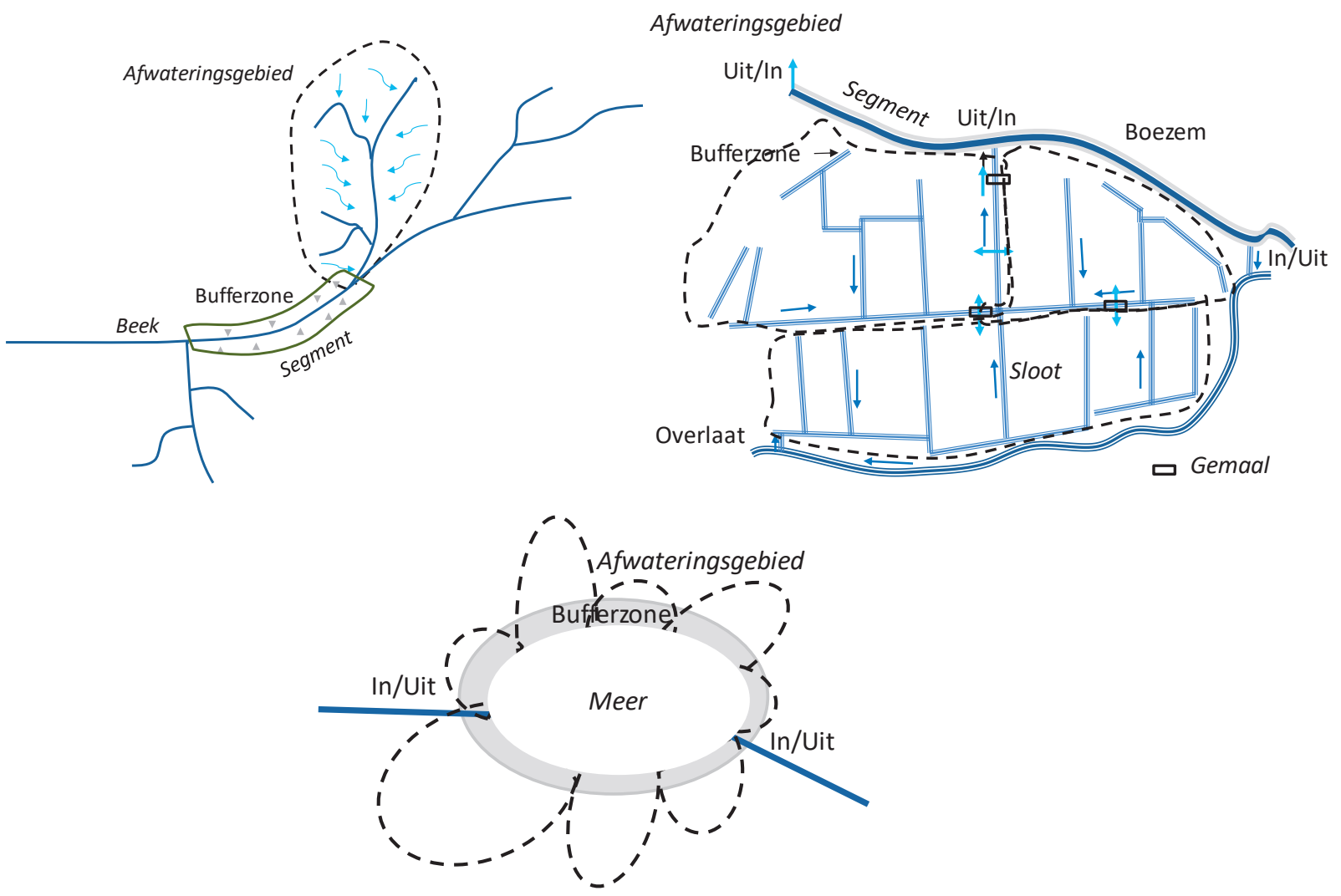
KADER: SCHAAL

In een ecologische systeemanalyse spelen schalen in ruimte en tijd een belangrijke rol (Levin 1992). Om schaal en de daarin opgenomen hiërarchie (naar Frissell et al. 1989) voor het regionale waterbeheer af te bakenen, gaan we binnen de ruimtelijke schalen uit van macroschaal (geografisch, watertype op basis van geologie, geomorfologie en klimaat), landschapsschaal (stroomgebied, hydrologische eenheid of polder), omgeving (begeleidende zone of omgeving zoals overstromingszone) en segment als deel van het waterlichaam (bodem, waterkolom en oeverzone). De macroschaal omvat de systeemvoorwaarden die niet of nauwelijks door beheer kunnen worden beïnvloed. In de tijd gaat het om de tijdspanne van het waterbeheer en de periode waarin relevante organismegroepen meer dan één generatie voltooien, wat voor algen, waterplanten, macrofauna en vissen sterk kan verschillen; variërend van dagen voor algen tot enkele tientallen jaren voor vissen.

\subsubsection{Oppervlaktewatertypering}

Vaak richt de ecologische systeemanalyse zich op een waterlichaam; een relatief homogeen functionerend deel van een beek, rivier, plas of meer en de omgeving van deze wateren. Binnen een waterlichaam, bijvoorbeeld stroomop- naar stroomafwaarts gekeken in een beek of in de directe omgeving (oude beekarmen) kunnen typologische verschillen optreden. Een gedetailleerde typering van het waterlichaam is dan ook erg behulpzaam bij het vaststellen van sleutelfactoren en -processen, referentie en streefbeeld. De factoren op basis waarvan watertypen worden onderscheiden zijn vaak gerelateerd aan de belangrijke systeemfactoren op macroschaal. De mate van detail in de typering (zoals bijvoorbeeld de 155 aquatische natuurdoeltypen of de 25 KRW-typen) en de criteria voor de classificatie (abiotisch, biotisch) hangen samen met het doel van een analyse. Gewoonlijk wordt een referentiesituatie (afgeleid van historische situaties, of huidige situaties met zo weinig mogelijk menselijke invloed) als uitgangspunt genomen. Stressoren leiden tot degradatie van het oorspronkelijke type, m.a.w. ieder type heeft een degradatie reeks of kwaliteitsreeks. Hoe verder een type is gedegradeerd, hoe meer het op sterk gedegradeerde stadia van andere typen gaat lijken; er treedt homogenisatie op van omstandigheden en levensgemeenschappen.

\subsection{Natuurlijk functioneren macrosysteem}

Het natuurlijk functioneren van het macrosysteem van een oppervlaktewater verwijst naar de oorspronkelijke toestand onder natuurlijke omstandigheden en wordt gezien als optimaal. Inzicht in de oorspronkelijke situatie (de systeemvoorwaarde afgeleid uit het functioneren op macroschaal in ruimte en tijd) helpt bij het vormen van een beeld van het natuurlijk functioneren van het systeem. Hoe meer van deze structuren en processen van het macrosysteem in de toekomst kunnen worden hersteld, hoe duurzamer de maatregeleffectiviteit wordt.

Met een referentie-analyse van het macrosysteem (vergelijking met de referentiesituatie; beschreven door Nijboer et al. 2004) wordt de abiotische en biotische situatie in het stroomgebied, de hydrologische eenheid of polder bepaald. Het gaat hierbij om op basis van de oorspronkelijke samenhang en het functioneren van de relevante systeemvoorwaarden t.a.v. klimaat, geohydrologie, geomorfologie en geochemie voor het te onderzoeken gebied te projecteren in de toekomst, met in het achterhoofd dat rekening moet worden gehouden met irreversibele veranderingen. Hierbij wordt gekeken naar wat hiervan bruikbaar is in de huidige tijd en relevant in het licht van toekomstige ontwikkelingen. Verder wordt gekeken naar wat er in het verleden aanwezig was en welke invloed dit heeft op de keuze van toekomstige ontwikkelingen. Alle irreversibele veranderingen uit het verleden worden als huidige randvoorwaarde beschouwd, bijvoorbeeld wanneer een eeuwenoud veenpakket is weggegraven dan worden de processen die daarmee samenhingen ook niet meegenomen maar vervangen door de situatie die in de toekomst wordt verwacht.

Juist de focus op de toekomstige milieuomstandigheden, o.a. door het veranderende klimaat, is van groot belang bij het kiezen van maatregelpakketten en het daarbij inspelen op de natuurlijke macrokenmerken en -processen van het studiegebied. Het voorkomt dat maatregelen spijtmaatregelen worden omdat de veranderde toekomstige en de systeemeigen omstandigheden niet meegenomen waren. Het macrosysteem bepaalt het ijkpunt, de stip aan de horizon, waarvan gebruik wordt gemaakt bij het streven naar verbetering. 
Om het macrosysteem te beschrijven, wordt antwoord gegeven op onderstaande vragen:

1. Wat zijn de voor de toekomst relevante systeemvoorwaarden t.a.v. klimaat, geohydrologie, geomorfologie en geochemie in het te onderzoeken gebied en wat is de samenhang en het potentieel functioneren?

2. Hoe zag het oorspronkelijke functioneren eruit en wat is daarvan niet onomkeerbaar veranderd (bijvoorbeeld bij het afgraven van veen of het graven van een zandwinput is dat deel van de oorspronkelijke situatie onomkeerbaar veranderd en speelt geen of juist een andere rol in de toekomst) en is dat nog relevant voor de toekomst?

3. Welke landschapstypen, met daarin het watertype/-lichaam in kwestie, waren aanwezig en hebben invloed op de keuze van toekomstige streefdoelen? Bijvoorbeeld kunnen we vroegere kwelgebieden weer zo laten functioneren dat de natuurlijke waterhuishouding hersteld wordt.

4. Hoe zou het water in kwestie en de directe omgeving ervan eruit zien op basis van het oorspronkelijk (reversibel deel) van het functioneren? Zijn er bijvoorbeeld wateren in Nederland of het buitenland te vinden die nog nagenoeg-natuurlijk zijn en hier passen. Het aquatisch supplement van de natuurdoeltypen kan hierbij behulpzaam zijn. In de macrosysteemanalyse wordt bekeken of water- en omringende landschapstypen weer zoals in het verleden kunnen functioneren of dat er inmiddels onomkeerbare veranderingen van het landschap en de systeemvoorwaarden hebben plaatsgevonden. In dat geval wordt bekeken hoe het functioneren er in de nieuwe situatie uit kan zien. Deze stap geeft inzicht in de potentie en beperkingen van maatregelen en geeft inzicht in hoe kansrijk bepaalde streefbeelden zijn. Deze benadering sluit aan bij het bepalen van maatregelen die gebaseerd zijn op het zoveel mogelijk gebruik maken van de natuurlijke (grootschalige) processen in een landschap en watersysteem (cf. bouwen-met-natuur).

Een macrosysteem-beschrijving kan voorzien worden van een lijst van soorten die van nature in de optimale situatie voorkwamen en potentieel kunnen voorkomen als de omstandigheden weer op dit niveau teruggebracht worden. Dit is echter niet noodzakelijk. Voor de potentiële soortenlijst van de referentie kunnen drie bronnen van informatie worden gebruikt:

(I) (Historische) soortenlijsten beschreven voor de referentiesituatie per regio of gebied, zoals een hydrobiologisch district, een regionaal vastgestelde referentie zoals de cenotypen Limburg (Verdonschot et al. 2000a,b,c,d), Overijssel, Gelderland en het duingebied.

(II) Soortenlijsten zoals beschreven in de achtergronddocumenten van het aquatische supplement van de natuurdoeltypen (Verdonschot 2000).

(III) Soortenlijsten van vergelijkbare situaties in het buitenland die nog wel in optimale toestand verkeren (Nijboer et al. 2004). 


\section{ECOSYSTEEMTOESTAND EN FUNCTIONEREN}

\subsection{Ecosysteemtoestand en ontwilkkelingsreeksen}

Een ecosysteemtoestand is de toestand van een ecosysteem uitgedrukt in abiotische en biotische parameters op een bepaald moment in ruimte en tijd. Vaak wordt de ecosysteemtoestand beschreven in de parameters die over een bepaalde tijdsperiode zijn bepaald, bijvoorbeeld het chlorofylgehalte in grote meren over de zomerperiode of een afvoerreeks van een beek gedurende een decennium. Data die behulpzaam kunnen zijn om de huidige toestand van het ecosysteem te beschrijven in de ecologische systeemanalyse omvatten minimaal de gemiddelde toestand over een jaar, zodat de variatie over de seizoenen wordt beschreven. Bij voorkeur omvat het echter meerdere jaren, zodat variatie in omstandigheden tussen de jaren (bijvoorbeeld door verschillen in weersomstandigheden) kan worden meegenomen. Momentopnames zijn voor dit doel niet bruikbaar. Het gaat hierbij om gekwantificeerde milieufactoren en biologische inventarisaties. Naarmate er meer gekwantificeerde gegevens over oorzaak-gevolg-relaties beschikbaar zijn, des te beter de ecosysteemtoestand kan bijdragen aan het vaststellen van knelpunten. Voor het beschrijven van de ecosysteemtoestand zijn niet alleen de biologische componenten van het waterlichaam van belang, maar ook die van de omgeving en het landschap (bijv. gegevens van de terrestrische natuur).

Onderling vergelijkbare ecosysteemtoestanden kunnen worden geclassificeerd of getypeerd op basis van de soortencombinatie en de milieuomstandigheden, meestal begrensd op basis van een combinatie van hydrologische, morfologische, fysisch-chemische en biologische kenmerken van een ecosysteem. Voorbeelden hiervan zijn de saprobie-klassen (Sláde ek 1966), de cenotypen (Verdonschot 1990) of de plantengroepen van stromend water (Holmes et al. 1998). Ecosysteemtoestanden kunnen worden gerelateerd aan bepaalde continue (gradiënten) of discontinue overgangen. Voorbeelden hiervan zijn de verschillende stadia van het ecosysteem binnen een successiereeks of stadia bij toe- of afname van de mate van eutrofiering, organische belasting, morfologische verandering of hydrologische wijziging (o.a. Carpenter 1981, van Wirdum et al. 1992, Biggs et al. 1994, Verhoeven 2013). Veranderingen in de kenmerken van een ecosysteem langs deze overgangen leiden tot een overgang van de ene naar de andere toestand (Figuur 5.1). De verschillende toestanden kunnen gewaardeerd worden op basis van de mate van ecosysteemontwikkeling, van vrijwel natuurlijk tot sterk gedegradeerd, of de invloed van stressoren (o.a. Wright et al. 1984, Duigan et al. 2007, Vilar et al. 2014: Figuur 5.2).

Met kennis van de verschillende in een gebied voorkomende ecosysteemtoestanden kan een te analyseren ecosysteem worden geclassificeerd langs een gradiënt van toestanden (zie bijvoorbeeld de bekentypologie (Verdonschot \& Nijboer 2004) en de slotentypologie (Nijboer et al. 2003)), wat erg helpt bij het herkennen van de factoren die een rol spelen in de degradatie van het systeem (knelpunten), bij het vinden van oorzaken van knelpunten, en bij het bepalen van de richting van verbetering en het kiezen van doelsoorten (het streefbeeld). 


\section{FIGUUR 5.1}

Voorbeeld ecosysteemtoestanden van de middenlopen van laaglandbeken in Overijssel (aangeduid met letter $S$ (stream) = laaglandbeek + nummer = cenotype; $c f$. Verdonschot 1990). Samen vormen de toestanden een netwerk, waarbij veranderingen in milieuvariabelen (aangegeven met pijlen in de richting van toename en de bijbehorende variabele) leiden tot overgangen van de ene in de andere ecosysteemtoestand (Verdonschot \& Nijboer 2000).

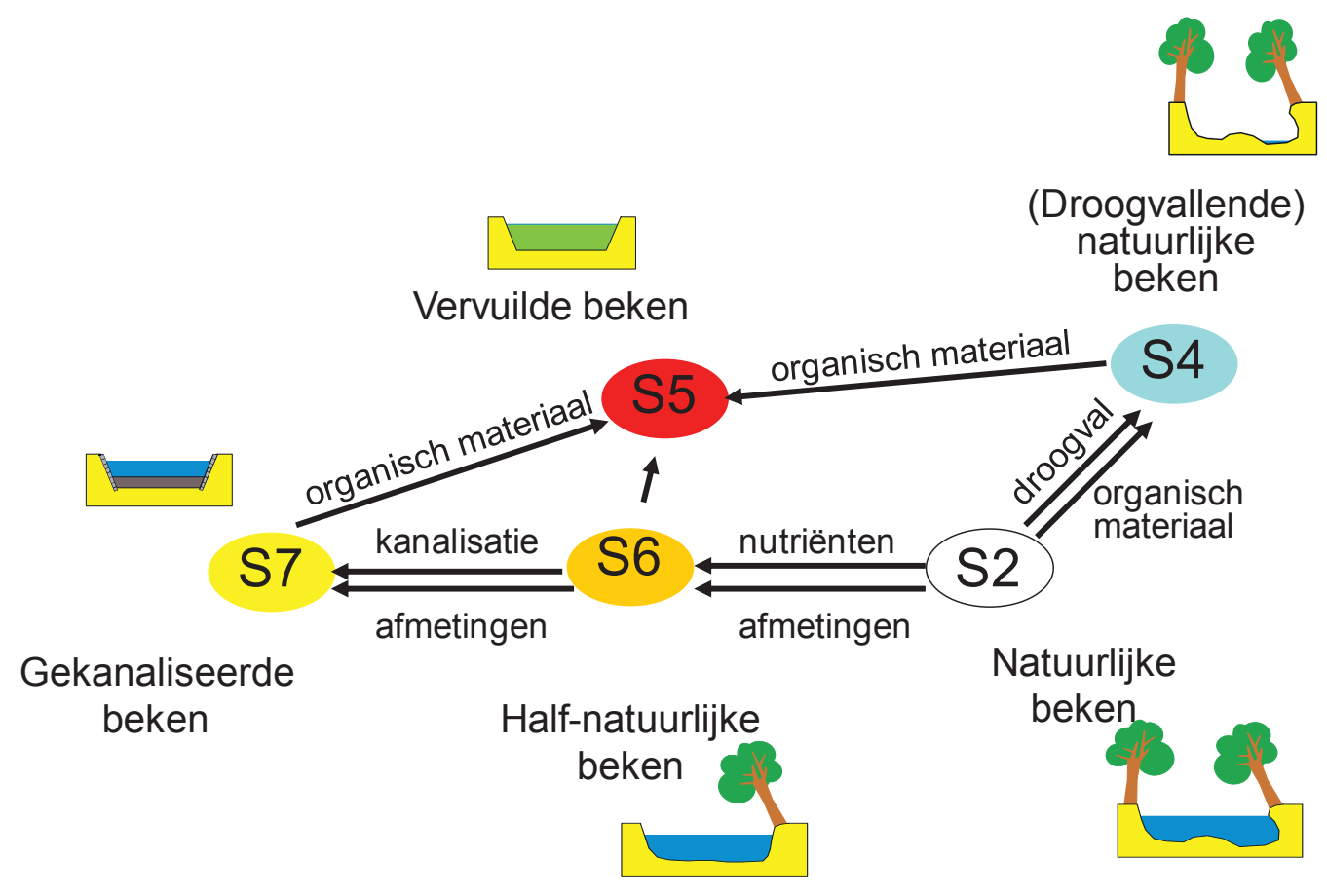

\section{FIGUUR 5.2}

Pyramidemodel van de ecosysteemtoestanden ingedeeld naar KRW-typen (type A, B, C en D) en kwaliteitstoestanden (5 klassen; naar Verdonschot 1983).

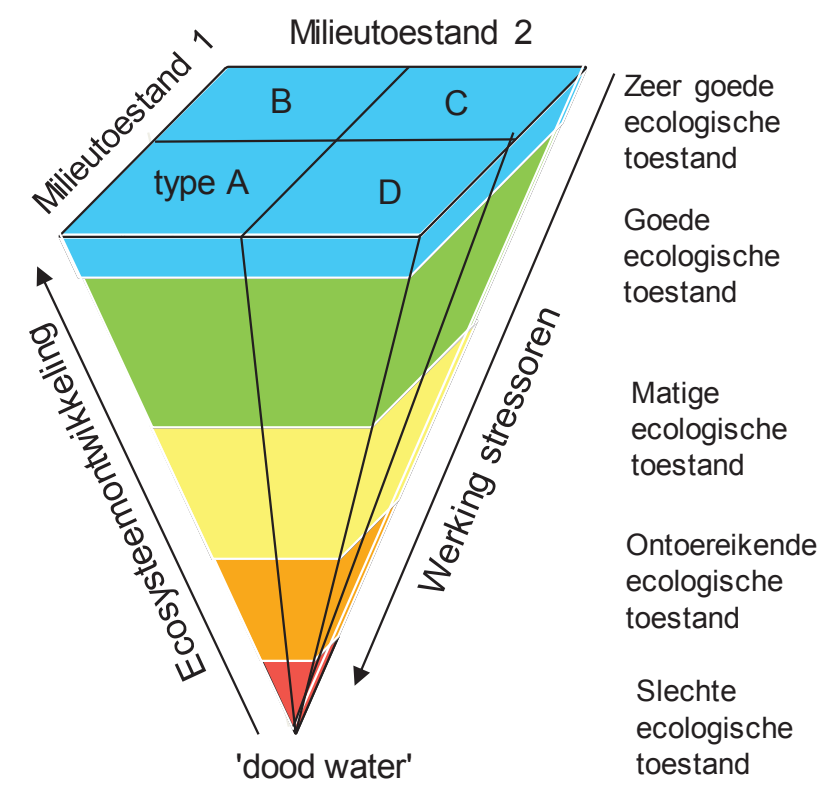




\section{KADER: ECOLOGISCHE SLEUTELFACTOREN}

\section{EN ECOSYSTEEMTOESTANDEN}

Een ecosysteemtoestand hangt nauw samen met de combinatie van waarden van de ecologische sleutelfactoren (bijv. Hussain \& Pandit 2012). Extreme waarden (in het lage of hoge bereik) van bepaalde ecologische sleutelfactoren leiden in natuurlijke situaties tot bijzondere ecosystemen, bijvoorbeeld bij tijdelijke droogval (Wellborn et al. 1993), extreme temperaturen (Jacobsen et al. 1997), een lage pH (Townsend et al. 1983) of een hoog chloridegehalte (Wolf et al. 2009). In situaties waarin de ecologische sleutelfactoren in de midden-range van het bereik van de factoren verkeren, leidt dit tot gemeenschappen die veel minder door een overheersende sleutelfactor worden gestuurd; de neutrale, permanente, langzaam stromende tot stilstaande, zoete, middelgrote, $\beta$-mesotrofe/-saprobe wateren (Figuur K5.I).

\section{FIGUUR K5.I}

Voorbeeld van de gradiënten in de richting waarlangs zich gemeenschappen hebben geëvolueerd.

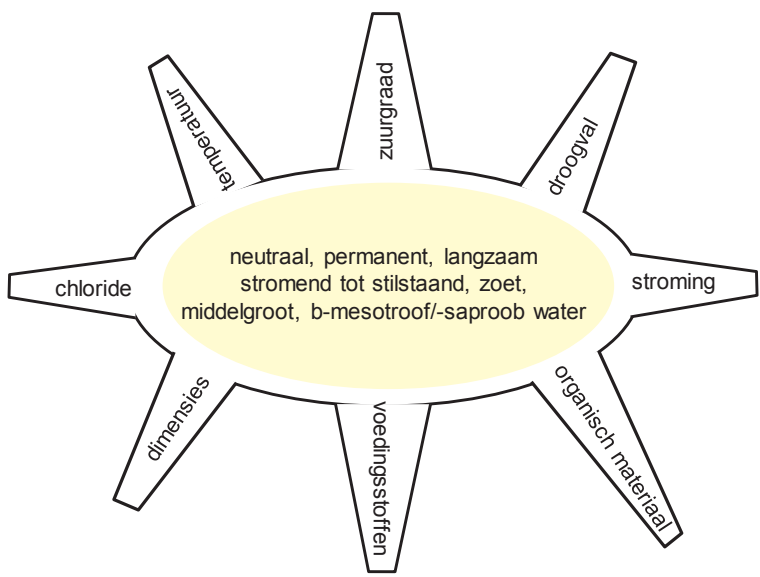

\subsection{ECOSYSTEEM FUNCTIONEREN}

Een ecosysteem kan gekenmerkt worden door de structuur die het heeft, in termen van relaties tussen factoren en soorten, en de wijze waarop het functioneert. De structuur wordt gedefinieerd als de abiotische en biotische toestand van een ecosysteem op een bepaald moment, terwijl het functioneren alle, meestal dynamische, processen omvat die plaatsvinden in de tijd (Figuur 5.3). Ecosysteemprocessen zijn gerelateerd aan veranderingen in het milieu, zoals bijvoorbeeld de kringloop van organisch materiaal, de afvoerdynamiek, de seizoenswisselingen en extremen zoals het plotseling optreden van een toxische lozing. Processen verbinden als het ware de toestandsvariabelen in het ecosysteem en maken het systeem veranderend of dynamisch. In de ecologische systeemanalyse komen de processen aan bod die ecologisch relevant zijn voor de aanwezige soorten.

\section{Figuur 5.3}

Voorbeeld van belangrijke processen (die direct samenhangen met de factoren in dezelfde figuur K5.I in het Kader Ecologische sleutelfactoren en ecosysteemtoestanden) in het ecosysteem functioneren.

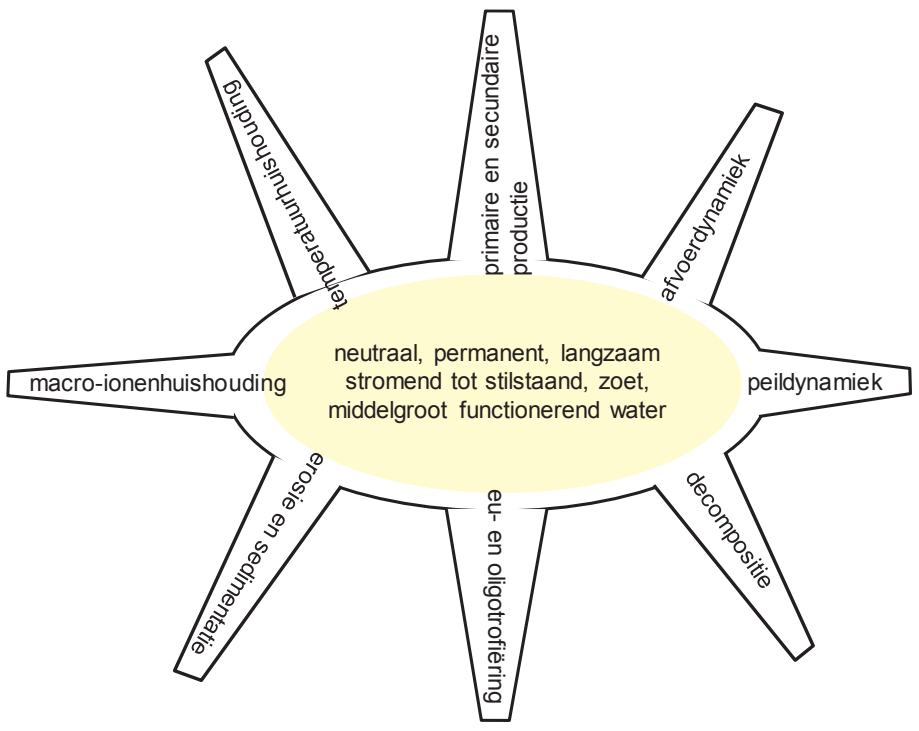




\subsection{STREEFBEELD EN ONTWIKKELINGSRICHTING}

Voordat maatregelen kunnen worden geselecteerd is het van belang om eerst te bepalen wat er binnen het macrosysteem haalbaar is en welke ontwikkelingsrichtingen mogelijk zijn. Scenario's beschrijven de stappen, in termen van maatregelen, die deze ontwikkeling mogelijk maken. Als stip op de horizon wordt een streefbeeld (eventueel meerdere) gekozen, bij voorkeur met de daarbij horende ontwikkelingsrichting(en). Een streefbeeld is een ecosysteemtoestand, uitgedrukt in abiotische en biologische kenmerken, die als doel wordt gesteld voor een oppervlaktewater en die ligt op een ontwikkelingsrichting tussen de huidige en de door het macrosysteem bepaalde referentietoestand.

Voor de abiotische kenmerken kunnen de grenswaarden voor milieufactoren, die het al dan niet voorkomen van gewenste soorten bepalen, zeer behulpzaam zijn.

Voor de potentiële soortenlijst van het streefbeeld kan gebruik worden gemaakt van:

(I) De actuele soortenlijst, die de soorten bevat die aanwezig zijn in de wateren in het afwateringsgebied in kwestie, met een gebied daaromheen. Het gebied om het afwateringsgebied heen bevat soorten die ontbreken in het afwateringsgebied, maar waarvan geacht wordt dat ze het afwateringsgebied op eigen kracht kunnen koloniseren als de omstandigheden hiervoor geschikt zijn na uitvoering van de maatregelen. Voor macrofauna wordt bijvoorbeeld een zone geprojecteerd rondom ieder afwateringsgebied van 5-15 kilometer breed die het verspreidingspotentieel voor de minder tot meer mobiele macrofaunasoorten aangeeft. Voor vissen is dit gebied nog vele malen groter wanneer er bijvoorbeeld een open verbinding met een rivier bestaat. Alleen relatief recente data (laatste 20 jaar) worden gebruikt om een zo actueel mogelijk beeld te krijgen van de soortenpoule, rekening houdend met de verhouding tussen trefkans en de meetfrequentie (iedere 3-5 jaar) die gewoonlijk gehanteerd wordt binnen monitoringsnetwerken.

(II) Een uit de referentie afgeleide soortenlijst. 


\section{ABIOTISCHE STRESSOREN EN DE BIOLOGISCHE RESPONS}

\subsection{Meervoudige abiotische stress}

\subsubsection{Inleiding}

Er is veel kennis beschikbaar over abiotische mechanismen, bijvoorbeeld de werking van processen in het abiotische milieu en de effecten hiervan op het biotische milieu. Van bijvoorbeeld de stikstof- en fosforcycli, erosie-sedimentatie-processen, windwerking, stratificatie en stroming zijn de milieufactoren die een rol in ieder van die processen spelen meestal bekend (zie Kader bemesting, waarin de stromen van fosfor en stikstof vanuit de landbouw naar het oppervlaktewater staan). Er is veel minder kennis over de biotische mechanismen, zoals competitie, facilitatie of dispersie.

In een ecologische systeemanalyse worden stressoren direct gekoppeld aan de ecologische respons en worden de achterliggende mechanismen bij voorkeur weggelaten. Die mechanismen worden als gegeven of een 'black-box' beschouwd, omdat die kennis voor de praktijk vaak alleen extra complexiteit toevoegt en niet nodig is voor de implementatie. De relevantie voor de ecologie bepaalt uiteindelijk wat van dergelijke processen wel en wat niet meegenomen wordt in de analyse. Door deze aanpak wordt voorkomen dat tijd en energie gestoken worden in details van abiotische processen die ecologisch niet of minder relevant zijn, het voorkomt dat rekentijden onnodig lang worden en het vermijdt fragmentarische benaderingen, omdat uiteindelijk toch niet alles bekend is van elk proces dat in een ecosysteem speelt. Dit maakt een ecologische systeemanalyse robuust, ecologisch relevant en praktisch hanteerbaar.

\section{KADER: BEMESTING}

De toevoer van stikstof en fosfor naar een agrarische bodem, de opname van deze stoffen door het gewas en de vervluchtiging en denitrificatie staan in directe relatie tot de instroom (bijvoorbeeld neerslag, kwel, infiltratie van oppervlaktewater) en uitstroom (verdamping, infiltratie naar de ondergrond en uitspoeling naar het oppervlaktewater) van water en de tijdelijke binding en veranderingen in de bodem (Figuur K6.I gewijzigd naar Groenendijk et al. 2013).

\section{FIGUUR K6.I}

Stromen van water, fosfor en stikstof in een agrarische bodem.

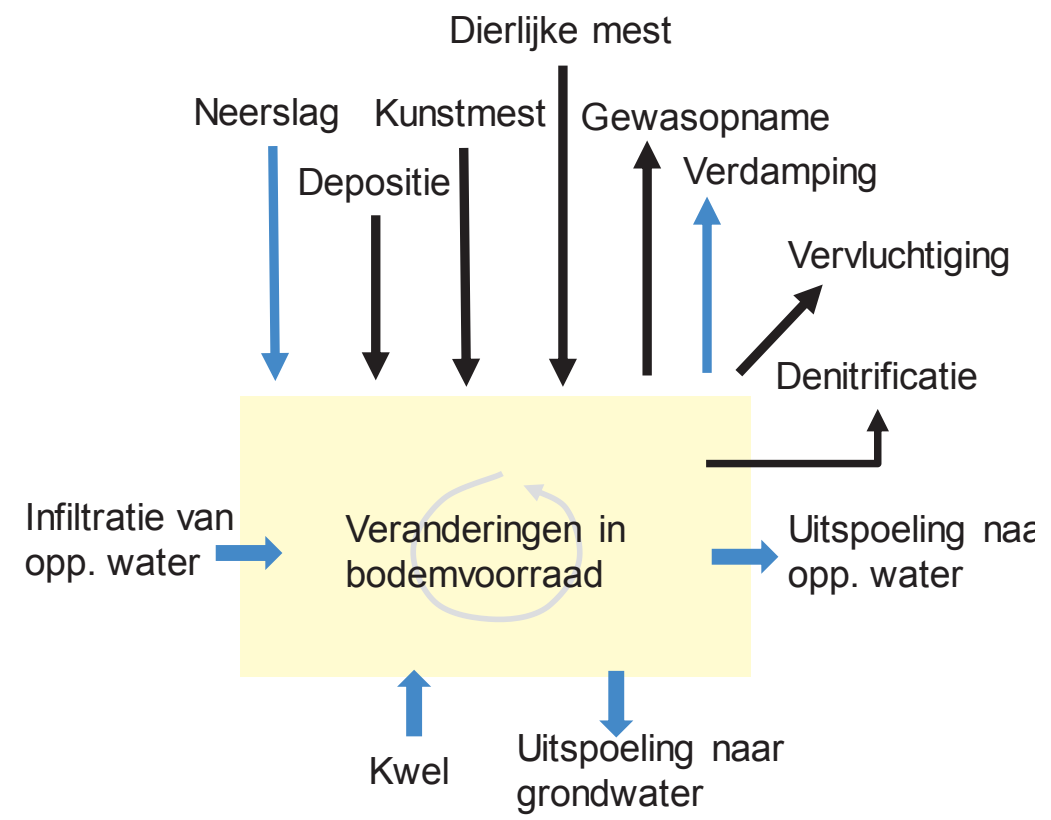


In een afwateringsgebied (zijstroomgebied of (deel)polder) en in een segment (incl. bufferzone) worden drie bronnen van stressoren onderscheiden (Figuur 6.1):

- Diffuse bronnen: De diffuse bronnen leveren vanuit agrarisch en urbaan landgebruik de volgende groepen stressoren: af- en uitspoeling (incl. drainage), kwelverandering, nutriënten, slib, gifstoffen en saliniteit.

- Puntbronnen: De puntbronnen zijn bijvoorbeeld effluent uit RWZI's, overstorten, industriële bronnen en inlaatpunten van gebiedsvreemd water met dezelfde stressoren, m.u.v. kwelverandering, als bij de diffuse bronnen.

- Interne bronnen ofwel bronnen in het waterlichaam zelf: In het oppervlaktewater zelf spelen stressoren die samenhangen met onder andere het ontbreken van schaduw (alleen bij beken), het ontbreken van kwel, piekafvoer/stagnatie/ permanentie/droogte, stuwing, profielvorm en -inrichting en zichtbare vervuiling.

De werkzame stressoren uit diffuse bronnen, puntbronnen en interne bronnen zijn in samenhang weergegeven. Iedere bron levert een bepaalde mate van stress. Zijn er meerdere bronnen, dan leidt dit samen tot een multiple stress situatie, oftewel er treedt een cumulatieve stress op.

\section{FIGUUR 6.1}

Drie bronnen van stress met voorbeelden van mogelijke stressoren.

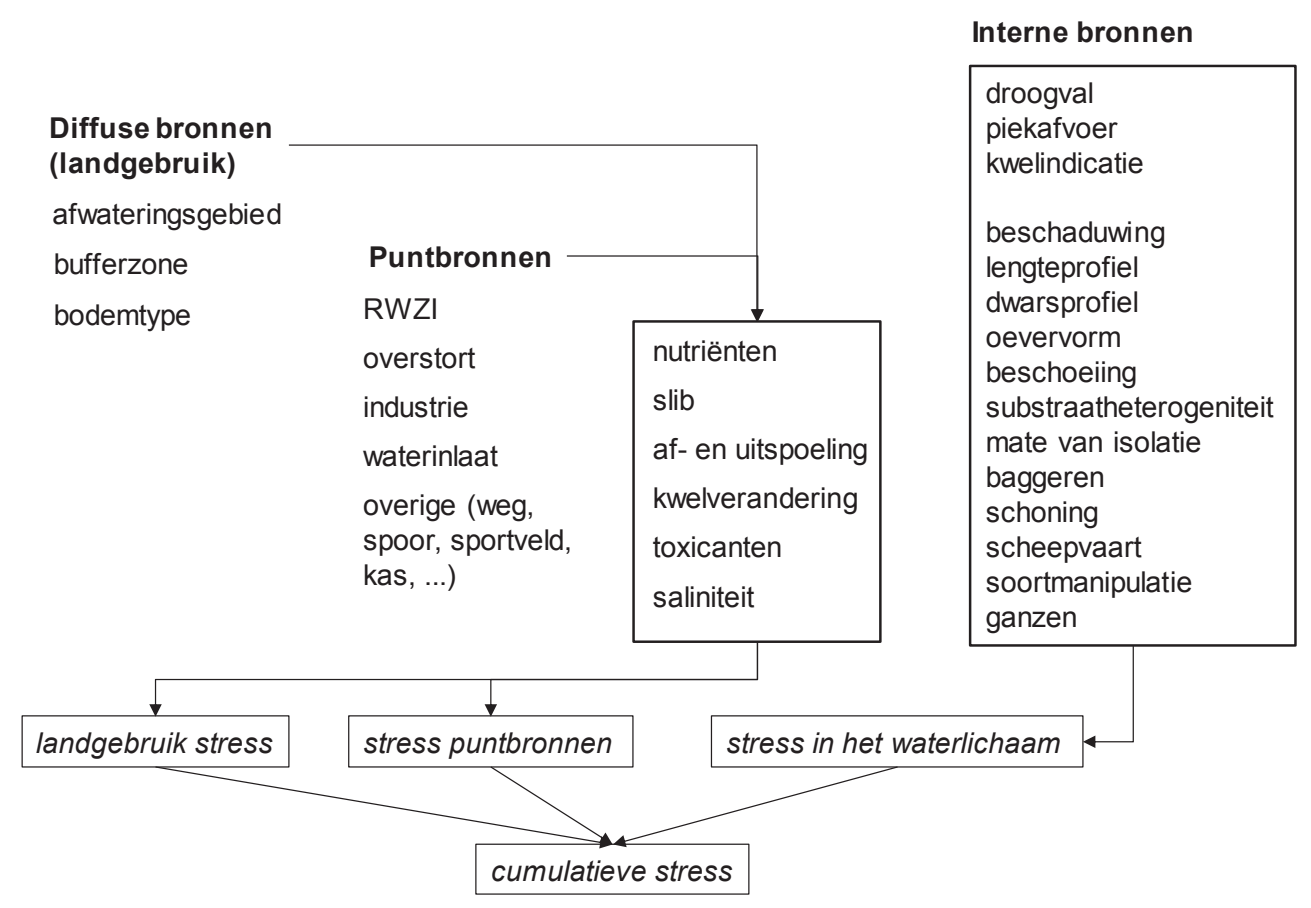

\subsubsection{Grenswaarden en belang van stressoren}

Stressoren werken in op ecologische sleutelfactoren. Daarbij volgen ze ook de hiërarchie in de factoren van het 5-S-model. Dat betekent automatisch dat niet alle stressoren even zwaar drukken op het aquatisch ecologisch systeem, maar dat de stress gewogen wordt naar gelang de hiërarchische positie, het watertype en de omvang van het effect. Hiërarchisch betekent dat de systeemvoorwaarden van groter belang zijn dan bijvoorbeeld de chemische factoren. Het houdt ook in dat wanneer een kritische waarde van een dominante parameter wordt overschreden, deze parameter boven die grenswaarde een allesoverheersend gewicht krijgt. Als bijvoorbeeld een maximale temperatuur waarboven dieren of planten verdwijnen wordt overschreden, dan wordt deze stressor van doorslaggevend belang. 
Het bereik waarbinnen factoren geen stress opleveren en de waarden die daarbuiten liggen waar de factoren minder of meer stress opleveren kunnen worden afgeleid van biologische informatie, zoals de WEW-autecologie lijst (Verberk et al. 2012) of andere overzichten van de milieu- en habitatpreferenties van soorten.

Stressoren worden geclassificeerd naar hun effect, bijvoorbeeld door ze in te delen op een schaal van lichte (factor -1) tot zware stress (factor -5). Deze stressklassen kunnen vervolgens worden gewogen en gemiddeld om uiteindelijk tot een totale stressscore te komen. De weging wordt bepaald door de hiërarchie en de parameterrange t.o.v. de biologische respons. Een voorbeeld is de zuurstofconcentratie. Zuurstof speelt alleen een belangrijke structurerende rol voor de aquatische fauna bij gehalten lager dan $6 \mathrm{mg} / \mathrm{l}$. Zakken de waarden onder de $2 \mathrm{mg} / 1$, dan wordt zuurstof alles bepalend. Daarom worden grenswaarden ('thresholds') in de stressklassen opgenomen (voorbeeld ranges Tabel 6.1). De middeling (omdat we overal te maken hebben met multiple stress) geeft een deel- of eindscore. Dit kan bijvoorbeeld per hoofdfactorgroep, zoals systeemvoorwaarden, stroming, structuren en stoffen.

\section{TABEL 6.1}

Voorbeeld van grenswaarden voor milieufactoren in beeksystemen voor macrofauna.

\begin{tabular}{|c|c|c|}
\hline & \multicolumn{2}{|c|}{$\begin{array}{l}\text { Grenswaarde (voorwaarde van meenemen } \\
\text { in de weging van een stressor) }\end{array}$} \\
\hline & Alles bepalend & Van belang \\
\hline \multicolumn{3}{|l|}{ Systeemvoorwaarden } \\
\hline Temperatuur & $>280 \mathrm{C}$ & $>120 \mathrm{C}$ (bronnen) \\
\hline \multicolumn{3}{|l|}{ >16oC (koele wateren) } \\
\hline Beschaduwing & $<10 \%$ & $<70 \%$ \\
\hline \multicolumn{3}{|l|}{ Stroming } \\
\hline Stroomsnelheid & $<5 \mathrm{~cm} / \mathrm{s}$ & niet laag dynamisch \\
\hline Droogval & frequentie: jaarlijks & \\
\hline duur: >6 weken (temporair), & $\begin{array}{l}\text { frequentie: }<1 \times 25 \text { jaar } \\
\text { duur: }<6 \text { weken }\end{array}$ & \\
\hline \multicolumn{3}{|l|}{ Structuren } \\
\hline Lengteprofiel & gekanaliseerd & niet natuurlijk \\
\hline Dwarsprofiel & genormaliseerd & niet natuurlijk \\
\hline Maaien & $>2 x$ per jaar & $>1$ keer per 2 jaar \\
\hline \multicolumn{3}{|l|}{ Stoffen } \\
\hline Organisch materiaal & polysaproob & a-mesosaproob \\
\hline Fosfor & hypertroof & eutroof \\
\hline Zuurstof & $<2-3 \mathrm{mg} / \mathrm{l}$ & $<6-7 \mathrm{mg} / \mathrm{l}$ \\
\hline Chloride & $>300$ mg/L & $>200$ mg/L \\
\hline Gifstoffen & $>\mathrm{NEC}$ & Aanwezig \\
\hline
\end{tabular}

\subsubsection{Berekenen van stress}

Voor de berekening van de cumulatieve stress wordt gebruik gemaakt van de ruimtelijke eenheden. Ruimtelijk gezien zijn er vier compartimenten van waaruit stressoren bijdragen aan de totale stress:

- Cumulatieve stress uit een afwateringsgebied (hydrologische eenheid, stroomgebied);

- Cumulatieve stress uit de directe omgeving (bijvoorbeeld een bufferzone);

- Stress in het waterlichaam zelf;

- Stress aangevoerd vanaf een ander deel van het waterlichaam (bijvoorbeeld een bovenstrooms beeksegment). 
Omdat per stressor de stress dimensieloos is gemaakt en geclassificeerd kunnen stressklassen onderling worden verrekend. Voor ieder compartiment wordt de cumulatieve stress afzonderlijk berekend.

Uiteindelijk kan een totale stress voor een (deel van een) waterlichaam worden berekend en omgekeerd kan de totale stress worden herleid naar de bron of bronnen waarmee oorzaakgerichte maatregelen kunnen worden genomen.

De waterbeweging zelf en het water als drager van stoffen spelen een belangrijke rol bij het berekenen van stress (Figuur 6.2). Het grond- en oppervlaktewater transporteert stoffen en deeltjes (slib, organisch materiaal) van, naar en in het water en bepaalt daarmee in belangrijke mate de fysisch-chemische kwaliteit van het water (de Vries et al. 2019).

\section{FIGUUR 6.2}

Voorbeeld van waterstromen in en nabij een waterlichaam.
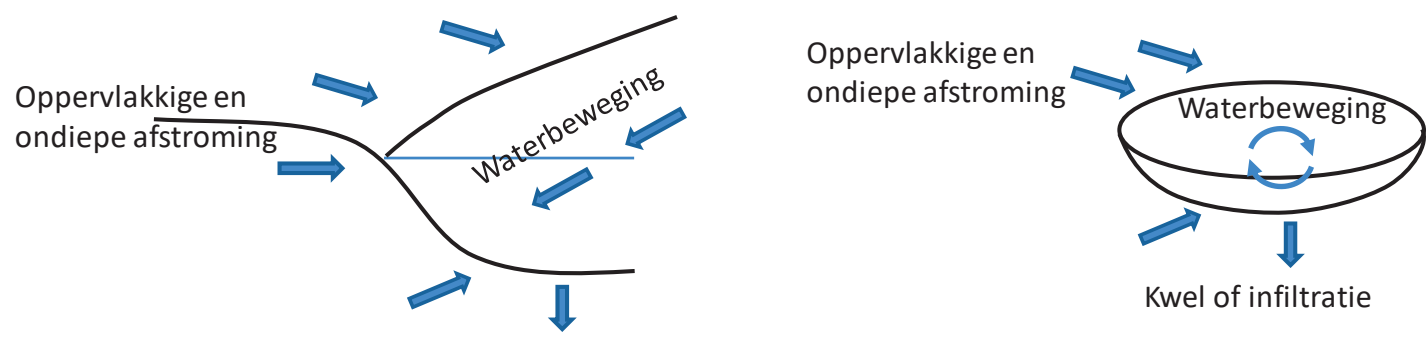

Kwel of infiltratie

Kwel of infiltratie

De hoeveelheid getransporteerd water per segment/deel van een waterlichaam in combinatie met de input van stoffen (bijv. nutriënten, milieuvreemde stoffen, chloride) en deeltjes (bijv. slib, organisch materiaal) bepalen de mate van stress in het betreffende watersegment/deel. Processen van omzetting en retentie kunnen deze mate van stress tijdens de waterbeweging verminderen. Dit betekent dat de waterbalans en de waterstromen in een ecologische systeemanalyse van groot belang zijn. Daarnaast kunnen veranderingen in de zone langs het waterlichaam, de vorm van het waterlichaam en de structuren die in het waterlichaam aanwezig zijn eveneens zorgen voor stress.

In een stressberekening worden fysische en chemische parameters in het waterlichaam zelf niet gescoord, omdat deze al verwerkt zijn in de verschillende bronnen van stress.

\subsection{BIOLOGISCHE RESPONS}

De biologie reageert op de abiotische en eventueel de biologische stress. Deze biologische respons kan worden gebruikt om de abiotische stress te duiden en eventueel te valideren. Voor het op biologische gronden berekenen van de mate van stress, de invloed van individuele stressoren of groepen van stressoren op de biologie kan gebruik worden gemaakt van:

(I) Generieke kwaliteitsinformatie. Op basis van de huidige verspreidingsgegevens van soorten in het stroomgebied, de polder of hydrologische eenheid wordt bepaald welke soorten op dit moment voorkomen en bij welke kwaliteitsklasse, waarbij de minimumkwaliteit leidend is voor het voorkomen in de andere klassen. Het voorkomen bij een minimumkwaliteit geeft informatie over de generieke tolerantie van een soort.

(II) Stressor-specifieke biologische informatie. Deze biologische stressorinformatie wordt direct berekend op basis van de samenstelling van algen, macrofyten, macrofauna en vissen. Door te kijken naar de indicaties van de individuele soorten of soortgroepen kan de aard en intensiteit van stress worden bepaald, zoals dat ook wordt toegepast in sommige beoordelingssystemen. Met de milieu-indicatiewaarden van (een selectie van) deze soorten wordt de mate van stress in de huidige toestand van locaties in het waterlichaam bepaald. Verschillende bronnen van milieu-indicatiewaarden zijn beschikbaar, zoals de voor macrofauna de milieu- en habitatpreferenties (Verberk et al. 2012), voor de vegetatie de CBS-indicatiewaarden en voor vissen de ecologische gilden. 
Daarnaast kan door de stressorindicatie van soorten uit de potentiële soortenlijst (een lijst met soorten die redelijkerwijs voor zouden kunnen komen) te vergelijken met die van de actuele lijst een nog specifieker beeld van de aan te pakken bronnen van stress worden opgebouwd (Figuur 6.3). Zijn de te verwachten soorten in beeld dan worden, in termen van sleutelfactoren, de milieueisen (milieu- en habitatpreferenties) van deze nog niet aanwezige maar verwachte soorten berekend en vergeleken met de soorten die al wel binnen het afwateringsgebied/waterlichaam voorkomen. Dit geeft een aanwijzing hoe de eisen van de soorten die nu niet in het afwateringsgebied/waterlichaam voorkomen zich verhouden met de soorten die net buiten het afwateringsgebied/waterlichaam te vinden zijn. Dit geeft weer inzicht in welke sleutelfactoren binnen het gebied/waterlichaam anders zijn dan daarbuiten. Ook kan hiermee mogelijk afgeleid worden of er nog bepaalde resterende knelpunten zijn die de soorten beperken te vestigen.

\section{FIGUUR 6.3}

Voorbeeld van een berekening van de stressindicatie voor hydrologie, morfologie, chemie en biologie op basis van de macrofaunasoorten in de multimetric AMOEBE. Hoe verder de rode lijn naar buiten reikt hoe slechter de conditie voor betreffende stressor op basis van de macrofauna is.

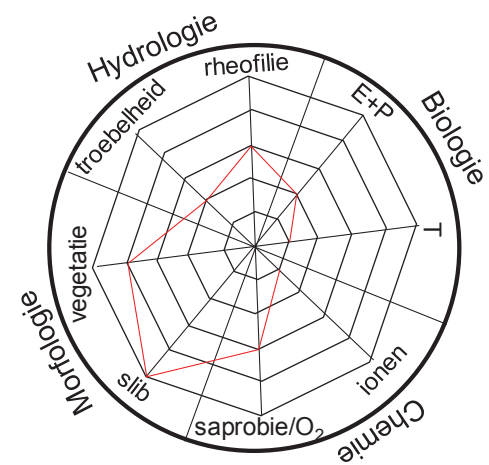

\subsection{KOPPELING ABIOTISCHE STRESS EN BIOLOGISCHE RESPONS}

De cumulatieve stress berekend uit de abiotiek en de stress berekend uit de respons van de biotiek kan met elkaar worden vergeleken als validatie van de daadwerkelijke toestand van het betreffende waterlichaam. Deze vergelijking wordt voor de totale stress uitgevoerd en, voor zover mogelijk, ook voor de ecologische sleutelfactoren afzonderlijk. Hiermee kan het belang van het aanpakken van specifieke stressoren zo goed mogelijk worden geduid.

De berekende abiotische stress en biotische respons scores kunnen ruimtelijk worden weergegeven op een kaart. Deze kaart kan eveneens als validatie-instrument worden gebruikt (Figuur 6.4). Met behulp van de kaart voor individuele stressor- en respons-gerelateerde scores kunnen ook specifieke knelpunten worden geduid.

\section{FIGUUR 6.4}

Grafisch voorbeeld van stressvalidatie uitgevoerd in de Tungelroyse beek i.s.m. Waterschap Limburg (de Vries et al. 2019).

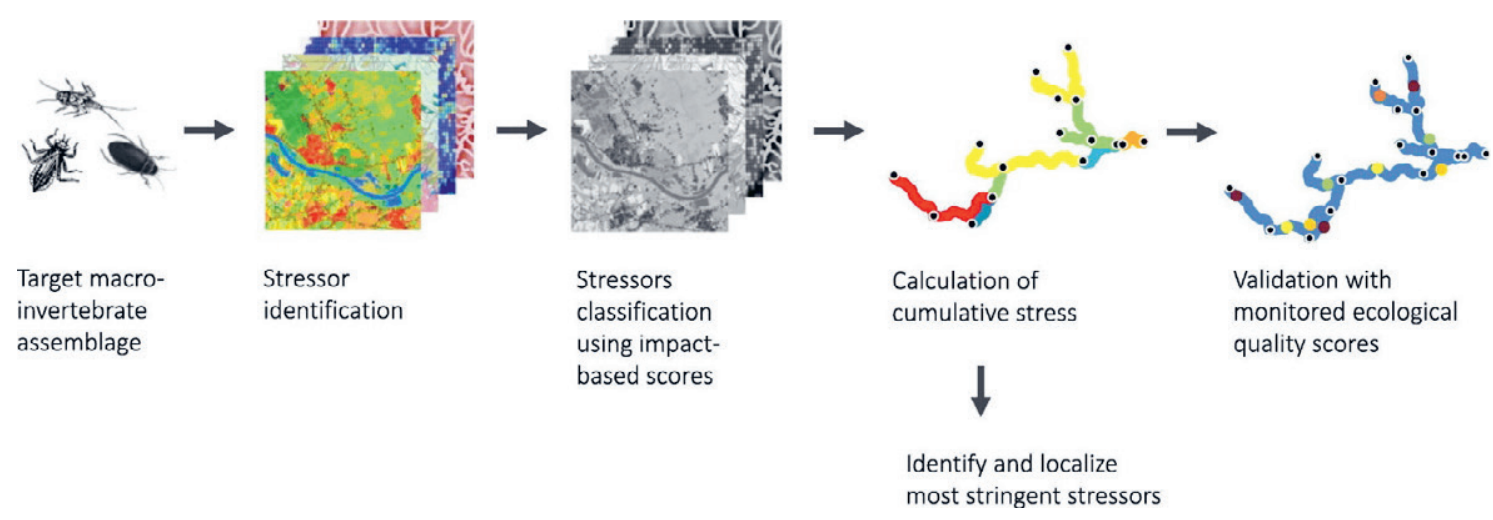




\section{MAATREGELPAKKETTEN EN SCENARIO'S}

\subsection{Maatregelen en maatregelpakketten}

Wanneer het macrosysteem, de huidige ecosysteemtoestand en de knelpunten bekend zijn kunnen maatregelen worden afgeleid. Er kunnen vier aangrijpingspunten voor maatregelen worden onderscheiden.

De eerste groep maatregelen die aangrijpen op de werkelijke oorzaak van stressoren, zoals bevolkingsgroei, industrie, landbouw of urbanisatie, worden hier niet besproken, omdat ze gebaseerd zijn op maatschappelijke keuzes.

De tweede groep betreft maatregelen die dicht op de oorzaak ingrijpen; de zogenoemde brongerichte maatregelen (Figuur 7.1). Een voorbeeld van brongerichte maatregelen zijn het terugdringen van het gebruik van meststoffen en van gifstoffen in de landbouw, m.a.w. het voorkomen dat er diffuse bronnen van stress ontstaan. Tussen de stressfactoren enerzijds en de effecten op de ecologische sleutelfactoren en de biologie anderzijds is een keten van interacties waarin ook op verschillende plaatsen langs die keten kan worden ingegrepen.

De derde groep betreft de zogenoemde effectgerichte maatregelen. Dit is een vorm van effectketengerichte maatregelen, die tussen de bron en het daadwerkelijk effect aangrijpen, zoals het aanleggen van bufferzones om de af- en uitspoeling van stoffen vanaf het aanliggende land in te vangen.

Tenslotte kan als vierde mogelijkheid ook direct actief in het ontvangende ecosysteem worden ingegrepen, de zogenaamde end-of-pipe maatregelen. Voorbeelden hiervan zijn biologisch beheer of het inbrengen van fosfaatbindende stoffen.

Hoe verder richting het einde van de keten maatregelen ingrijpen, hoe minder effect ze zullen hebben en hoe kleinschaliger ze worden. Maatregelen eerder in de keten, zoals het instellen van bufferzones, het vasthouden van water en het ontwikkelen van moerassen rond meren, hebben een grotere ruimtelijke schaal en een groter effect over langere termijn. Een bronaanpak is daarmee veel duurzamer en effectiever dan een effectgerichte of end-of-pipe-aanpak. Vanuit de ecologie ligt de prioriteit daarom bij het nemen van brongerichte maatregelen.

Moeten er toch effectgerichte maatregelen worden genomen, dan is het van groot belang dat alle door de stress beïnvloede factoren in het ecosysteem gelijktijdig verbeteren. In het bovenstaande voorbeeld van het landbouwkundig gebruik gaat het dus niet alleen om de meststoffen en de gifstoffen, maar ook om het aanpakken van bijvoorbeeld de waterhuishouding (ontwateringsniveau en afspoeling) en de oeverinrichting (geen landbouwkundig beheer tot aan de insteek). Door, in het voorbeeld van landbouwkundige activiteit, een maatregel te nemen die alleen de hydrologie herstelt, kan ecologische herstelontwikkeling uitblijven, omdat de nutriënten en eventueel andere stressoren, zoals toxische stoffen, nog een knelpunt vormen. Pas als deze ook worden aangepakt, kan herstel optreden. Dit betekent dat wanneer er geen brongerichte maatregelen kunnen worden genomen, maatregelpakketten samengesteld moeten worden met effectgerichte maatregelen die zo dicht mogelijk bij de bron van de verstoring liggen en zo alle knelpunten oplossen. 
FIGUUR 7.1

Van brongerichte via effectgerichte naar end-of-pipe maatregelen om fosforbelasting terug te dringen met een indicatie van de afnemende effectiviteit.

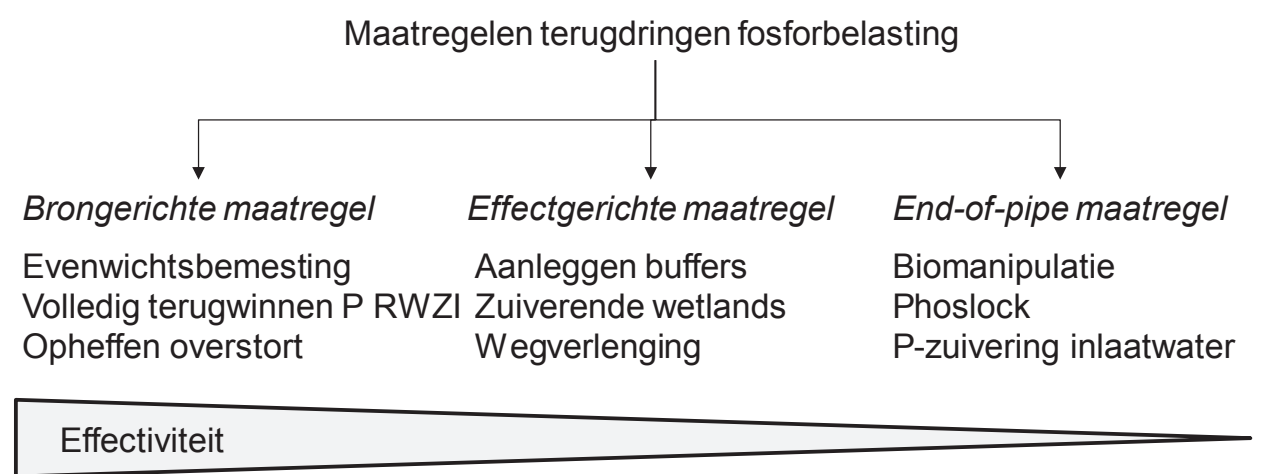

Met de oorzaak-stressfactoren-respons keten kan de relatie tussen oorzaak van een stressor en gevolg, het effect op het ecosysteem, in beeld worden gebracht. Voor het kiezen van maatregelen is kennis van deze keten aan relaties noodzakelijk. Kennis van de keten biedt de mogelijkheid om op verschillende plaatsen in de keten in te kunnen grijpen om effecten op te heffen of te verminderen, m.a.w. maatregelen te treffen.

In de praktijk is het echter vaak niet nodig om steeds weer de gehele keten te in beeld te brengen voordat maatregelen gekozen kunnen worden. De invloed van de verschillende milieufactoren op soorten en ecosystemen is in veel gevallen terug te brengen tot een zeer beperkt aantal oorzakelijke of ecologische sleutelfactoren, zoals het zuurstofregime voor zuurstofminnende macrofauna. Daarnaast weten we ook dat een aantal soorten met indicatieve functionele eigenschappen kunnen optreden als proxy (meetbare parameter die gebruikt kan worden om andere, niet direct of moeilijk meetbare, parameters of processen te representeren) voor de structuur van het ecosysteem en het functioneren ervan. De praktijk kan hierdoor volstaan met een vereenvoudigde keten (Figuur 7.2). Deze is onder te verdelen in de veroorzakers (diffuse bronnen, puntbronnen en interne bronnen), stressoren (factoren of factorcomplexen die sturend zijn voor de ecologische sleutelfactoren), responsies (effecten door indicatieve soorten geïndiceerd) en tenslotte de maatregelen (ingrepen die bij voorkeur veroorzakers en anders stressoren aanpakken).

\section{FIGUUR 7.2}

Het vereenvoudigde oorzaak-stressfactoren-respons-maategel relatieschema (zie figuur 1.1) als basis voor de ecologische systeemanalyse.

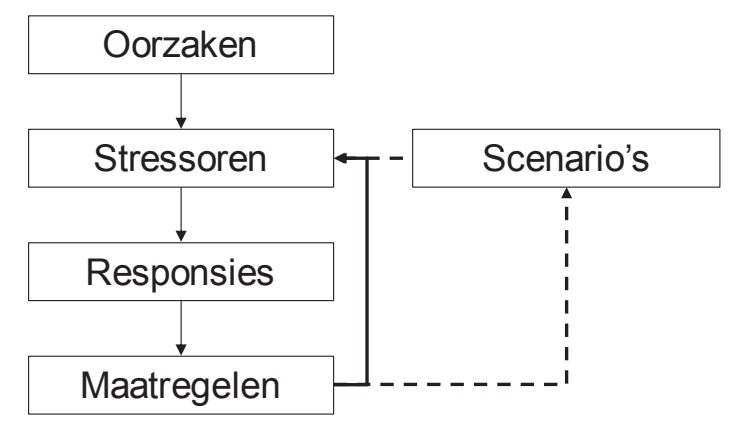

Omdat het wegnemen van multiple stress situaties in de meeste gevallen vraagt om combinaties van maatregelen, worden maatregelpakketten samengesteld die samen tot een verbetering van de ecologie leiden. 


\subsection{Voorbeeld van een maatregelpakket}

Maatregelpakketten zijn combinaties van maatregelen die gelijktijdig de multiple stress die ontstaat als gevolg van menselijke activiteiten verminderen of tenietdoen. Om op lokale schaal effecten te zien van maatregelen is het van belang op basis van een ecologische systeemanalyse (SESA) de lokale knelpunten in beeld te krijgen. In Nederland zal vrijwel altijd sprake zijn van een multiple stress situatie, wat betekent dat een maatregelpakket bijna altijd bestaat uit maatregelen t.a.v. stroming en structuren en stoffen, waar nodig aangevuld met maatregelen voor systeemvoorwaarden en soorten.

Op basis van een inventarisatie onder alle waterbeheerders is een lijst van maatregelen opgesteld (Tabel 2.4 in het achtergrond deel). De lijst is verdeeld naar hoofdwatertypen en schaal. Uit deze lijst kunnen maatregelpakketten worden samengesteld die locatie of regio-specifiek zijn en aansluiten op de geïdentificeerde knelpunten.

Hierna is een voorbeeld uitgewerkt voor een pakket aan regio- of locatie-specifieke maatregelen om de stress door intensief agrarisch landgebruik in een beeklandschap teniet te doen.

\section{Voorbeeld}

Het agrarische landgebruik heeft tot een groot aantal stressoren geleid, waarvan de intensiteit tot op de dag van vandaag nog steeds toeneemt. Deze stressoren grijpen in op systeemvoorwaarden, stroming, structuren en stoffen in aquatische ecosystemen en hun directe omgeving. De benodigde maatregelen kunnen in een maatregelpakket worden samengevoegd dat uit de volgende onderdelen bestaat:

\section{Systeemvoorwaarden}

- Houtige vegetatie aanplanten of laten ontwikkelen die de stromende wateren beschaduwt (verkoeling, verminderde lichtinval).

\section{Stroming}

- Verwijderen van zo veel mogelijk drainerende infrastructuur zoals sloten en greppels, drainagesystemen in landbouwgrond om de infiltratie te vergroten.

- Minder diep draineren en handhaven van hogere grondwaterstanden om de watervoorraad in de bodem te vergroten.

- Ontwikkelen van moerassen in het stroomgebied (doorstroom- en beekbegeleidende moerassen) of hydrologische eenheid zoals een polder (met broekbossen en zeggemoerassen) die water kunnen bergen. Soms kan dit ook in retentie- of bergingsvijvers die ook andere gebruiksfuncties dienen. Steeds ruimte vrijhouden voor inundatie. Infiltratie en berging zorgen samen voor het voorkomen van verdroging en piekafvoeren.

- Het toelaten van natuurlijke peilen.

\section{Structuren}

- Waterlichaam-begeleidende of omringende zone inrichten als buffer. Bij stilstaande lijnvormige wateren is dit een grazige zone, bij plassen, meren en stromende wateren is dit een houtige zone, al dan niet in combinatie met een grazige zone (zie bijvoorbeeld het 5-B-concept; Verdonschot 2010).

- Stromende wateren versmallen en verondiepen, met een onregelmatig lengte- en dwarsprofiel. Stilstaande wateren voorzien van (zeer) flauwe boven- en onderwatertaluds.

Stoffen

- Het aanbrengen van lage oeverwallen langs het waterlichaam om directe afspoeling naar het waterlichaam te voorkomen. 


\subsection{Scenario's}

Maatregelpakketten kunnen bestaan uit verschillende combinaties van maatregelen en iedere combinatie kan worden getest in een scenario. Scenario's zijn bij uitstek geschikt om de mogelijkheden te verkennen om een gewenste toestand te bereiken (zoals een realistisch streefbeeld voor de nabije toekomst). Bij het samenstellen van scenario's worden de toekomstige ontwikkelingen in land- en ruimtegebruik en andere socio-economische ontwikkelingen meegenomen. Scenario's zijn realistisch als tegelijkertijd wordt afgeleid wat er mogelijk en haalbaar is in het gebied wat betreft de terugkeer van doelsoorten en de milieueisen die deze stellen in relatie tot de door de maatregelen verbeterde kwaliteit van de beektrajecten.

Scenario's kunnen de ideale situatie (de referentie), landschapsbrede of afwateringsgebiedsdekkende maatregelen of combinaties van maatregelen bevatten. Voor het doorrekenen van een scenario, bijvoorbeeld met de SESA-methode, worden de stressorscores aangepast voor de stressoren. Hiervoor wordt gesimuleerd dat de stressoren zijn verminderd of weggenomen voor de gebieden of delen van het betreffende oppervlaktewater die door een of meerdere maatregelen uit een maatregelpakket worden beïnvloed. Er kan bij deze berekeningen uitgegaan worden van een optimale maatregeleffectiviteit op het moment van de effectbepaling maar ook van deeleffecten. Voor elk scenario wordt de ruimtelijke verdeling van stressorscores op een kaart weergegeven en vergeleken met die in de huidige situatie. De methode voor het in kaart brengen van stressoren in de huidige situatie wordt ook gebruikt om de effecten van scenario's in beeld te brengen zodat deze één op één vergelijkbaar zijn. 


\section{DEEL III \\ BOUWSTENEN \\ ECOLOGISCHE \\ SYSTEEMANALYSE}

$\rightarrow$ 


\section{ALGEMENE ACHTERGRONDEN}

\subsection{Factoren en -processen}

De ecologie bestudeert de relaties van organismen (populaties, soorten, gemeenschappen; de biotische milieufactoren) met hun niet-biologische omgeving (de abiotische milieufactoren) en de wisselwerking tussen organismen onderling. Het belang van een milieufactor is context-afhankelijk (o.a. Clements et al. 2012). Dit betekent dat niet elke milieufactor in ieder water en op elk moment hetzelfde effect heeft, maar dat het effect verschilt van plaats tot plaats en tijdstip tot tijdstip. Het betekent ook dat vanuit de optiek van organismen lang niet alle abiotische en biotische milieufactoren in een water een directe of oorzakelijke voorwaarde zijn om aanwezig te zijn, noch oefenen alle milieufactoren altijd een neutrale, positieve (versterking) of negatieve (stress) invloed uit op soorten. En geredeneerd vanuit het waterbeheer kunnen lang niet alle milieufactoren direct worden aangestuurd.

Daarom wordt, o.a. afhankelijk van het doel, de visie of discipline, onderscheid gemaakt tussen allerlei categorieën van milieufactoren, bijvoorbeeld tussen conditionele en operationele factoren of tussen ecologische sleutelfactoren, stuurfactoren en stressfactoren (Verdonschot 2015). Deze laatste drie worden in dit document het meest gehanteerd. De ecologische sleutelfactoren definiëren de leefruimte (niche) van een organisme en zijn direct oorzakelijk voor het organisme van belang. Factoren die door het waterbeheer direct gestuurd worden, de stuurfactoren, zijn bijvoorbeeld de vorm van een waterlichaam na inrichting, maaien, baggeren, bevissen en de mate van verstuwing. Stuurfactoren kunnen overlappen met sleutelfactoren maar vaak is dat niet het geval (zie voorbeeld in Tabel 8.1).

\section{Tabel 8.1}

Voorbeelden van relaties tussen milieufactoren, ecologische sleutelfactoren en stuurfactoren voor factoren behorende tot de systeemvoorwaarden

\begin{tabular}{|c|c|c|c|c|}
\hline Hoofdgroep & Factorgroep & Milieufactor & Ecologische & Stuurfactor \\
\hline \multicolumn{5}{|c|}{ Systeemvoorwaarden } \\
\hline & klimaat & & & \\
\hline & & temperatuur & temperatuur & schaduw \\
\hline & & neerslag & stroming, droogval, stroming & \\
\hline & & licht & licht & schaduw, diepte \\
\hline & & wind & stroming & (oever)vorm \\
\hline & geomorfologie & & & \\
\hline & & hoogteverschil & stroming & weglengte, stuwing \\
\hline & & natuurlijke vorm & licht, stroming, zuurstof, stroming & vorm \\
\hline & geologie & & & \\
\hline & & bodem & substraat, structuur heterogeniteit & \\
\hline & geohydrologie & grondwater & droogval & \\
\hline & geochemie & & buffercapaciteit & kwel \\
\hline
\end{tabular}

Daarnaast kunnen milieufactoren ook onderverdeeld worden naar directe en indirecte factoren. Indirecte factoren sturen de ecologische sleutelfactoren aan. Zo is bijvoorbeeld voor macrofauna het profiel van een beek niet direct sturend voor het aanwezig zijn van soorten; het is zodoende geen ecologische sleutelfactor. Profiel heeft echter wel invloed op de aanwezigheid van bepaalde substraattypen in de beek. Het substraat is een sleutelfactor, die in directe zin de aanwezigheid van soorten in de beek bepaalt (o.a. Tolkamp 1980). 
De onderverdeling tussen direct en indirect kan ook voor stuurfactoren worden gemaakt. Zo is de bemestingsnormering een indirecte factor om de nutriëntenbelasting te sturen. Het planten van bomen langs de beek stuurt direct de lichtinval via de gecreëerde beschaduwing, wat weer doorwerkt op de watertemperatuur. Zowel licht en temperatuur zijn daarbij ecologische sleutelfactoren, omdat deze van direct belang zijn voor de beekorganismen. Indirect kan het planten van bomen ook doorwerken op bijvoorbeeld de nutriëntentoevoer, levering van organisch materiaal (Vannote et al. 1980), structuur (migratie soorten) en het invangen van slib.

Ook al wordt vanuit de toepassing onderscheid gemaakt tussen sturende factoren, ecologische sleutelfactoren en stressfactoren, de essentie van de ecologie en dus ook ecologische systeemanalyse is de samenhang en onderlinge interacties tussen deze factoren.

\subsection{Ecologische sleutelfactoren en -processen}

Voor de ecologische systeemanalyse is een vereenvoudigde oorzaak-gevolg keten voldoende. De biologie is direct afhankelijk van de ecologische sleutelfactoren. De ecologische sleutelfactoren zijn in 2010 door circa 40 experts per hoofdwatertype benoemd en aangevuld met literatuur (Tabel 8.2). Dit leverde een groot aantal relatieschema's die zijn gerapporteerd en in dit document aangepast naar Verdonschot (2015). De ecologische sleutelfactoren zijn door de experts voorzien van een wegingsfactor (in de tabel teruggebracht tot 3 klassen) die de mate van belang voor de betreffende organismegroep in het betreffende watertype aangeeft.

Welke factor vervolgens het meest beperkend is, kan per situatie verschillen. De eenheden constantheid en variatie, m.a.w. het verloop van een factor in de tijd, zouden bij de meeste factoren eveneens toegevoegd kunnen worden. Voor veel organismen is het erg belangrijk dat de milieuvariabelen redelijk constant of voorspelbaar zijn in de tijd en variëren in de ruimte. Zo is bijvoorbeeld een situatie met een constante, toereikende zuurstofconcentratie te verkiezen boven een temporeel hogere, maar sterk fluctuerende zuurstofconcentratie.

Veel ecologische sleutelfactoren hangen ook met elkaar samen, waardoor variabelen moeilijk los van elkaar kunnen worden gezien. Zo hangen in stromende wateren droogval, peil, afvoer, stroming, zuurstof en temperatuur met elkaar samen. Verder blijken indirecte factoren vaak een sterk sturende werking te hebben.

Gemiddeld zijn er 8 (6-11) factoren per combinatie organismegroep-watertype van belang. Dit zijn de ecologische sleutelfactoren die het abiotische doel vormen waarop met maatregelen direct gestuurd zou moeten worden. De meeste factoren bestaan uit complexen zoals de zuurgraad in samenspel met de buffercapaciteit en het bicarbonaatgehalte, lage zuurstofgehalten en nitriet, ammoniak en sulfidegehalten, kwel en bicarbonaat en calcium of substraat in typen en heterogeniteit. De factoren en factorcomplexen temperatuur, licht, droogval, substraat, zuurgraad en macrofyten zijn bijna voor alle groepen en typen naar voren gebracht als zijnde van cruciaal belang. Met deze ecologische sleutelfactoren hangen ook de ecologische sleutelprocessen samen (Tabel 8.3). 
TABEL 8.2

Overzicht van alle sleutelfactoren en wegingsfactor per KRW organismegroep en hoofdwatertype $(1=$ sterk bepalend, $2=$ bepalend, 3 = zwak verband).

\begin{tabular}{|c|c|c|c|c|c|c|c|c|c|c|c|c|c|c|c|c|c|c|}
\hline 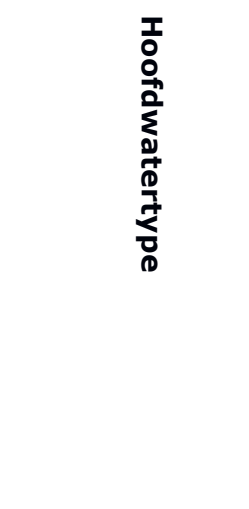 & 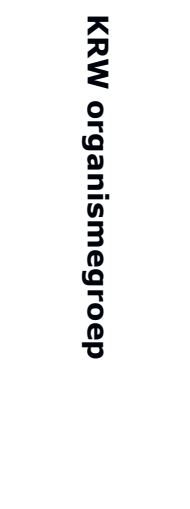 & 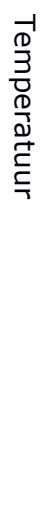 & 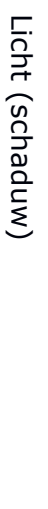 & 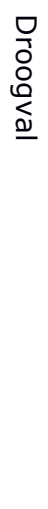 & 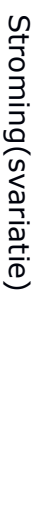 & 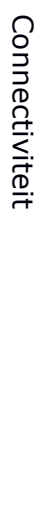 & $\frac{\frac{D}{D}}{\frac{D}{D}}$ & $\begin{array}{l}\text { O } \\
\frac{D}{0} \\
\frac{D}{2} \\
\frac{1}{2} \\
\frac{D}{\lambda} \\
\frac{1}{D}\end{array}$ & 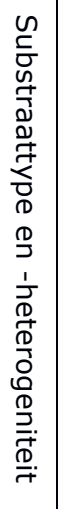 & 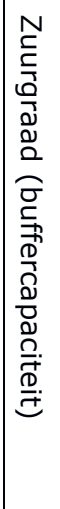 & $\begin{array}{l}\underline{\underline{\omega}} \\
\overline{\overline{\bar{n}}} \\
\overline{\mathrm{c}} \\
3\end{array}$ & $\begin{array}{l}3 \\
\frac{1}{0} \\
\frac{1}{3} \\
\frac{1}{0} \\
\frac{1}{0} \\
\frac{1}{1}\end{array}$ & 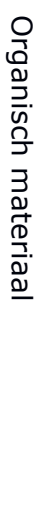 & 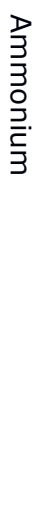 & \begin{tabular}{l}
$\stackrel{N}{N}$ \\
$\stackrel{c}{c}$ \\
\multicolumn{1}{c}{} \\
0 \\
0 \\
0 \\
n
\end{tabular} & 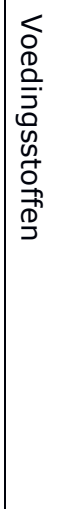 & 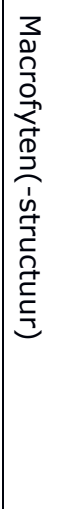 & 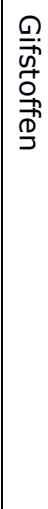 \\
\hline \multirow[t]{4}{*}{ beken, riviertjes } & algen & 2 & 2 & 1 & 2 & & & & 1 & 1 & 2 & 1 & & 2 & & 2 & 2 & 2 \\
\hline & $\begin{array}{l}\text { submerse } \\
\text { macrofyten }\end{array}$ & 2 & 1 & 1 & 1 & & & & 1 & 1 & & 1 & & & & 1 & & \\
\hline & macrofauna & 1 & 3 & 1 & 1 & & & & 1 & 1 & & & 1 & & 1 & & 1 & \\
\hline & vissen & 1 & 1 & 1 & 1 & 2 & & & 1 & 2 & & & & & 1 & & 1 & \\
\hline \multirow[t]{4}{*}{ sloten, kanalen } & algen & 2 & 1 & 1 & & & & & 2 & 1 & 2 & 1 & & 2 & & 2 & 3 & 2 \\
\hline & $\begin{array}{l}\text { submerse } \\
\text { macrofyten }\end{array}$ & 2 & 1 & 2 & & & & & 1 & 2 & & 2 & & & & 1 & & 1 \\
\hline & macrofauna & 1 & 3 & 1 & & & 1 & & 1 & 1 & & 2 & 1 & & 1 & & 1 & 1 \\
\hline & vissen & 2 & 1 & 1 & & 3 & 1 & 3 & 2 & 2 & & & & & 1 & & 1 & \\
\hline \multirow[t]{4}{*}{$\begin{array}{l}\text { plassen, kleine } \\
\text { meren }\end{array}$} & algen & 2 & 1 & 1 & & & & & 2 & 1 & 2 & 1 & & 2 & & 2 & 3 & 2 \\
\hline & $\begin{array}{l}\text { submerse } \\
\text { macrofyten }\end{array}$ & 2 & 1 & 1 & & & & & 1 & 1 & & 3 & & & & 1 & & \\
\hline & macrofauna & 2 & 3 & 1 & & & 1 & & 1 & 1 & & 2 & 1 & & 1 & & 1 & \\
\hline & vissen & 2 & 1 & 1 & & 3 & 1 & 3 & 1 & 2 & & & & & 2 & & 1 & \\
\hline \multirow[t]{4}{*}{ grote meren } & algen & 2 & 1 & 1 & & & & & 2 & & 2 & 1 & & 2 & & 2 & 3 & 2 \\
\hline & macrofauna & 3 & 3 & & & & & & 3 & 1 & & 2 & 1 & & 1 & & & \\
\hline & $\begin{array}{l}\text { submerse } \\
\text { macrofyten }\end{array}$ & 3 & 1 & & & & & & 1 & 1 & & 2 & & & & 1 & & \\
\hline & vissen & 3 & 1 & & & 3 & 3 & 3 & 3 & 2 & & & & & 3 & & 3 & \\
\hline
\end{tabular}


TABEL 8.3

Ecologische sleutelfactoren en een selectie van de achterliggende sleutelprocessen.

\begin{tabular}{|c|c|}
\hline Ecologische sleutelfactor & Sleutelproces \\
\hline \multirow[t]{4}{*}{ temperatuur } & Luchttemperatuurregime \\
\hline & Lichtinval (beschaduwing) \\
\hline & Lichtdoordringing (helderheid) \\
\hline & Bodemadsorptie (diepte) \\
\hline \multirow[t]{2}{*}{ licht } & Lichtinval (beschaduwing) \\
\hline & Lichtdoordringing (helderheid) \\
\hline \multirow[t]{2}{*}{ droogval } & Verdamping (temperatuur, neerslag) \\
\hline & Wegzijging (kwel) \\
\hline \multirow[t]{3}{*}{ stroming(svariatie) en waterbeweging } & Afvoerregime (toevoer) \\
\hline & Geomorfologie (verhang) \\
\hline & Morfologische processen (structuurvariatie) \\
\hline connectiviteit & Verbinding \\
\hline \multirow[t]{2}{*}{ diepte } & Erosie-sedimentatie \\
\hline & Baggeren \\
\hline oppervlakte & Home range (thuisbereik) \\
\hline \multirow[t]{4}{*}{ substraattype en -heterogeniteit } & Toevoer (b.v. bladval, afstroming) \\
\hline & Hydraulische en morfologische processen \\
\hline & Macrofytengroei \\
\hline & Verwijderen (baggeren) \\
\hline \multirow[t]{3}{*}{ zuurgraad (buffercapaciteit) } & Neerslag-aandeel \\
\hline & Chemische processen in bodem of ontbreken daarvan \\
\hline & Sphagnum-ontwikkeling \\
\hline silicium & Af- en uitspoeling, bodemchemische processen \\
\hline \multirow[t]{3}{*}{ macro-ionen } & Geomorfologisch processen \\
\hline & Bodemchemische processen \\
\hline & Wateraanvoer \\
\hline \multirow[t]{3}{*}{ organisch materiaal } & Toevoer (b.v. Bladval, afstroming) \\
\hline & Afsterven macrofyten en algen \\
\hline & Decompositieprocessen \\
\hline ammonium & Decompositieprocessen \\
\hline \multirow[t]{5}{*}{ zuurstof } & Productie \\
\hline & Consumptie \\
\hline & Aeratie \\
\hline & Diffusie \\
\hline & Anaerobie; vorming ammoniak, nitriet, sulfide \\
\hline \multirow[t]{4}{*}{ voedingsstoffen } & Toevoer (inwaaien, afstroming, toestroming, depositie) \\
\hline & Decompositieprocessen \\
\hline & Bodemchemische processen \\
\hline & Toevoer vanuit diffuse en puntbronnen \\
\hline \multirow[t]{4}{*}{ macrofyten(-structuur) } & Voedingsstoffenhuishouding \\
\hline & Bodemprocessen \\
\hline & Lichtinval \\
\hline & Verwijderen (maaien) \\
\hline gifstoffen & Toevoer vanuit diffuse en puntbronnen \\
\hline
\end{tabular}

\subsection{Directe relaties tussen sleutelfactoren}

Omdat factoren altijd onderling en over verschillende ruimtelijke en tijdschalen in verband staan, en om vooruit te kunnen kijken (o.a. voorspellen), is kennis van interacties tussen factoren en het functioneren van systemen (processen) een eerste vereiste (Turner et al. 1998). Voorbeelden van interacties tussen factoren zijn dominantie, de ene factor overheerst andere factoren waardoor deze minder van invloed zijn, en terugkoppeling, de ene factor heeft een positief of negatief effect op andere factoren.

Individuele factoren of groepen facto $\neg$ ren zijn onderling van elkaar afhankelijk, zo ook de ecologische sleutelfactoren 
(Figuur 8.1). Zo zijn bijvoorbeeld in een stromend water 'structuren', zoals bladpakketten, het gevolg van 'stroming' in de vorm van afvoer (de Brouwer 2020). De afvoer wordt voor een belangrijk deel bepaald door de hoeveelheid neerslag en het hoogteverschil in een gebied en de sponswerking van de bodem ('systeemvoorwaarden'), maar de 'structuren' in en op de oevers van de beek zijn tot op zekere hoogte in staat om de afvoer ('stroming') te beïnvloeden, bijvoorbeeld door de omvang van afvoerpieken te verminderen (Allan \& Castillo 2007). Ondanks een dominante werking van hoge naar lage schaalniveaus, bijvoorbeeld van systeemvoorwaarden naar stroming naar structuren, is er altijd in zekere mate een terugkoppeling aanwezig in omgekeerde richting; de interactie tussen factoren binnen en tussen schalen is steeds aanwezig, maar verschilt in hiërarchie en intensiteit (Naiman et al. 1999).

$\mathrm{Al}$ deze factoren en hun interacties vormen een zeer complex netwerk dat een ecosysteem doet functioneren. Toch hoeven niet alle relaties en interacties bekend te kunnen zijn om ermee aan de slag te kunnen en daar maakt de voorgestelde ecologische systeemanalyse gebruik van (zie Deel I). Een ecologische systeemanalyse begint altijd met het afbakenen van de hydrologische eenheid die bestudeerd gaat worden, bijvoorbeeld een waterbeheereenheid, stroomgebied of polder. Hierna worden de hierbinnen aanwezige kleinere ruimtelijke eenheden (het ruimtelijk schaal aspect), hun ruimtelijke samenhang (bijvoorbeeld boven- naar benedenstrooms) en de belangrijkste aanwezige processen die over kortere of langere tijd werkzaam kunnen zijn (het temporele schaal aspect) onderscheiden. Met andere woorden, de ruimte en tijd waarbinnen een vraag of doel speelt moet vooraf worden gedefinieerd. En dit geldt ook voor de relevante (groepen van) milieufactoren.

\section{FIGUUR 8.1}

Interacties tussen ecologische sleutelfactoren.

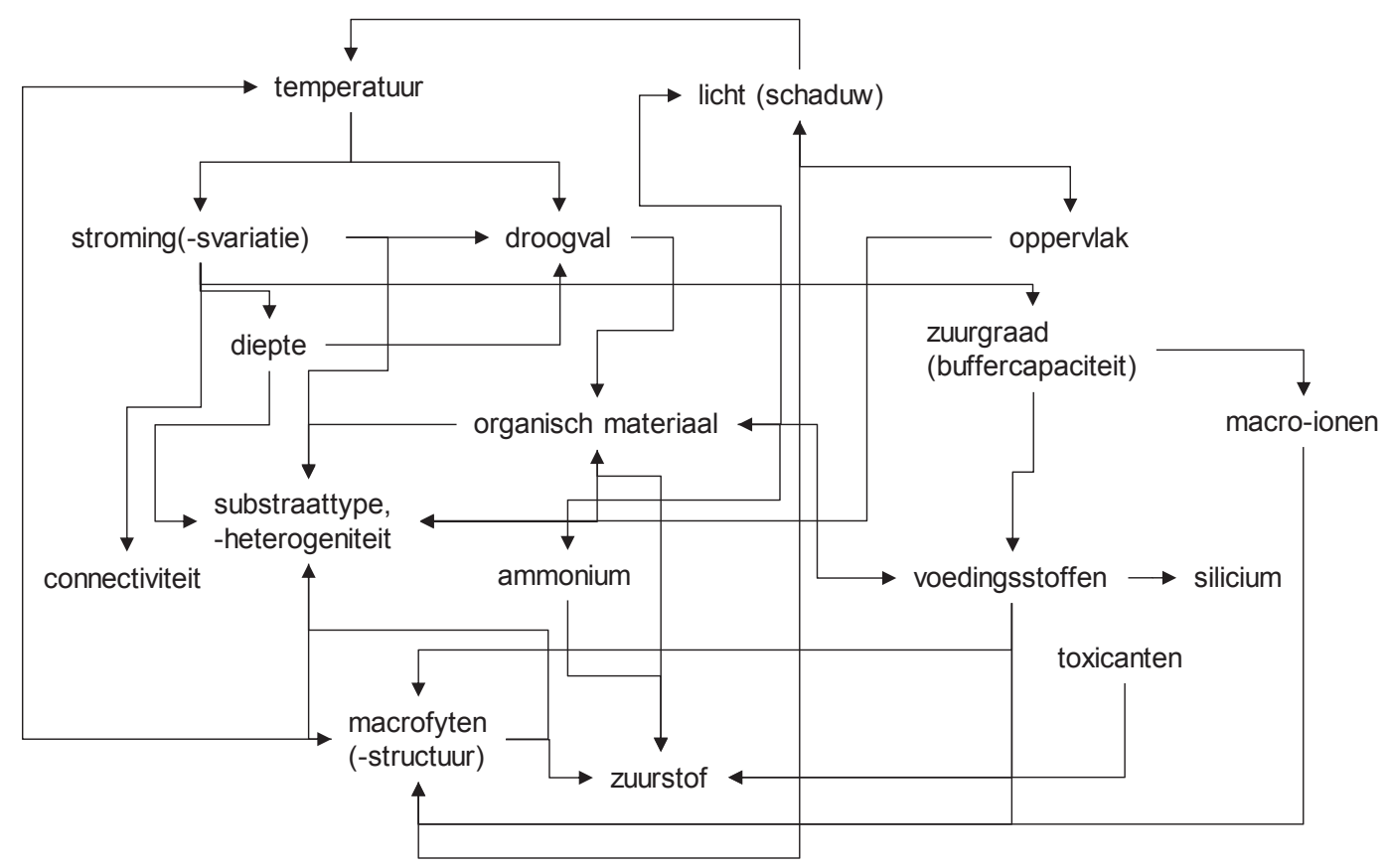

\section{4 'Indirecte' relaties in het waterecosysteem}

De ecologische sleutelfactoren zijn direct voor de organismen van belang. Ze werken dus direct in op de soorten en ze worden zelf weer "gestuurd" door indirecte factoren. De voor soorten indirecte relaties in het waterecosysteem kunnen zeer complex zijn. Als voorbeeld zijn twee relatieschema’s opgesteld, één voor de relaties van systeemvoorwaarden met stroming (hydrologie), structuren (morfologie), stoffen (chemie) en soorten (biologie) (Figuur 8.2) en één voor de relaties tussen de stroming (hydrologie), structuren (morfologie) en stoffen (chemie) (Figuur 8.3). 


\section{FIGUUR 8.2}

Voorbeeld van een selectie van relaties van processen en factoren van systeemvoorwaarden met stroming, structuren, stoffen en soorten. Ecologische sleutelfactoren zijn groen.

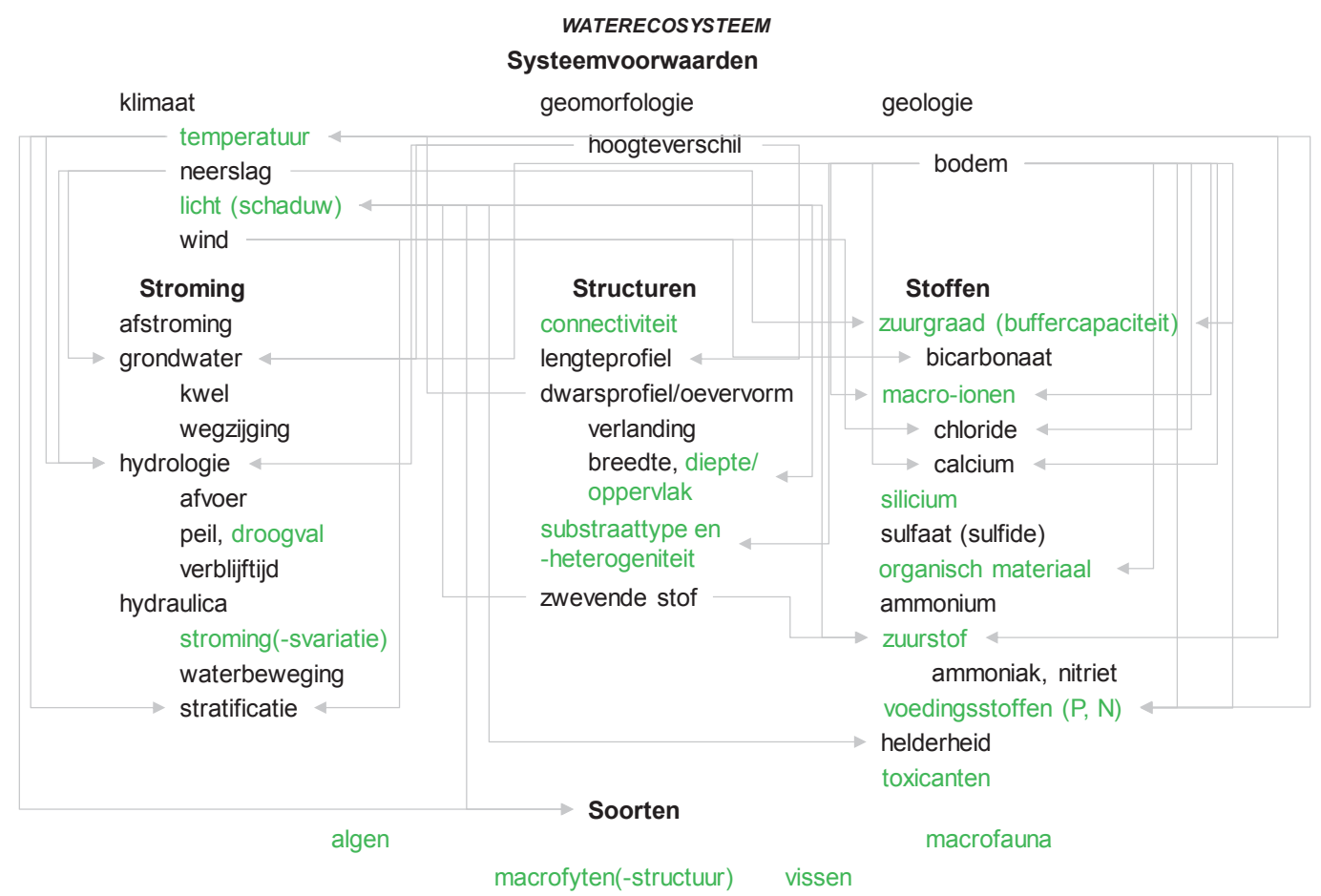

\section{FIGUUR 8.3}

Voorbeeld van een selectie van relaties tussen processen en factoren van stroming, structuren, stoffen onderling. Ecologische sleutelfactoren zijn groen.

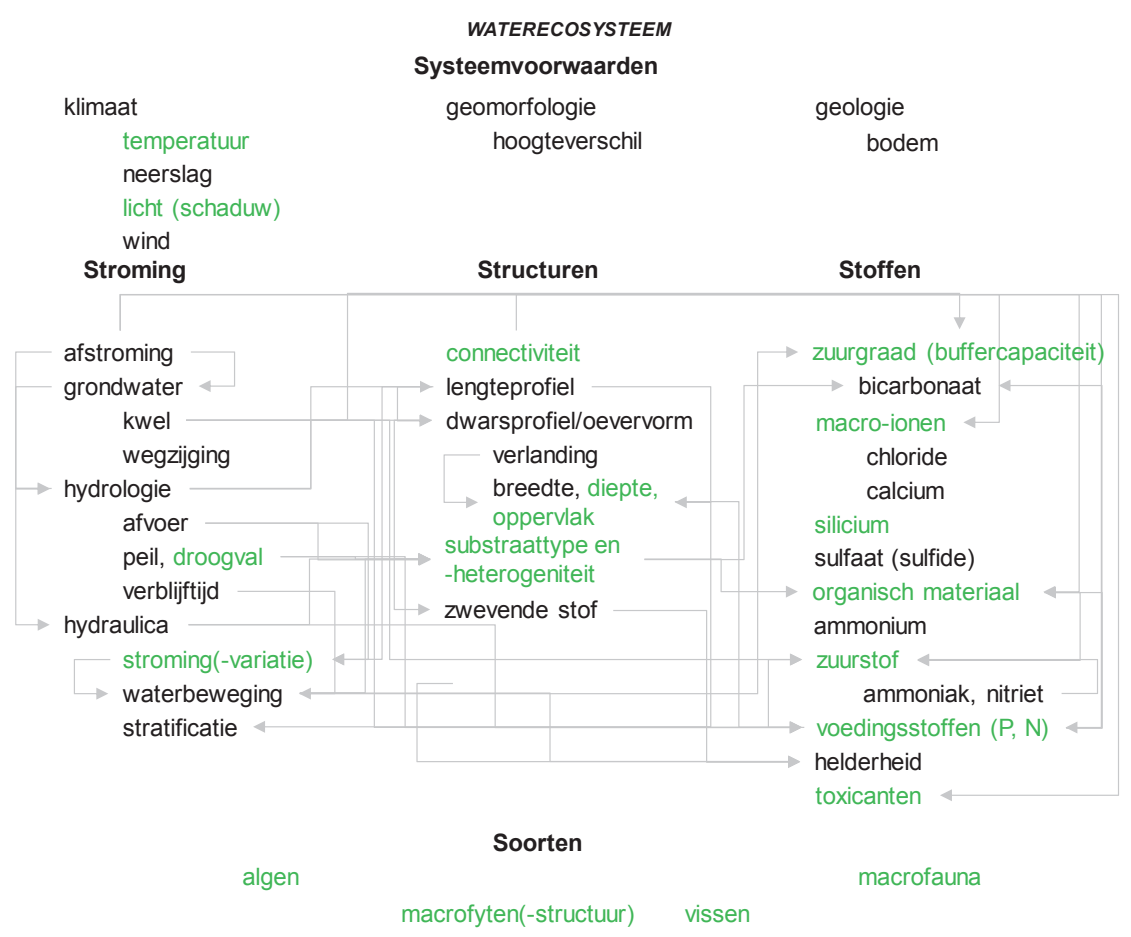




\subsection{Biologische relaties}

Een in het concept van de ecologische sleutelfactoren, stuurfactoren en stressfactoren nog niet behandeld aspect is de rol van biologische relaties of interacties (Holomuzki et al. 2010). Deze interacties kunnen een belangrijke rol spelen in waterecosystemen en zo de ecosysteemtoestand beïnvloeden. Biologische interacties kunnen worden verdeeld in voedselweb interacties (Polis et al. 1997, Carpenter 2012, McIntosh 2017) en niet-voedselweb interacties. Er zijn binnen voedselwebben veel relaties bekend die medebepalend zijn voor interacties tussen soorten. Biologische relaties vormen vaak ook ecologische sleutelfactoren, die het al dan niet voorkomen van soorten of de populatiegrootte bepalen.

Niet-voedsel relaties zijn in ecologische netwerken minstens zo belangrijk als voedselrelaties. Hun rol is medebepalend voor welke soorten ergens kunnen voorkomen. Voorbeelden zijn:

- Facilitators (Cardinale et al. 2002): Een facilitator faciliteert een andere soort, zoals het faciliteren van schuilplaatsen voor de fauna door boomwortelgroei vanuit de oever.

- Amensalisme (Ricciardi 2001): Bij amensalism remt de ene soort de andere af, zoals bomen die schaduw geven en daardoor waterplantengroei afremmen. Er worden twee typen amensalisme onderscheiden: competitie en antibiose. Bij competitie sluit een groter of krachtiger organisme een ander organisme uit van zijn bron van habitat of voedsel, zoals bij bijvoorbeeld competitie om ruimte (bijvoorbeeld groeivormen van planten) of licht (zoals waterlelies die ondergedoken planten in de schaduw zetten) (Barrat-Segretain 1996, Hautier et al. 2009). Bij antibiose scheidt het ene organisme een chemische stof af die het andere organisme doodt, terwijl degene die de chemische stof heeft afgescheiden ongedeerd blijft.

- Commensalisme: Bij commensalisme heeft de ene soort voordeel, terwijl de ander niet wordt beïnvloed. Een voorbeeld zijn zoetwaterborstelwormen die zich massaal vestigen in het slib dat zich ophoopt in een kluwen driehoeksmosselen op een meerbodem.

- Eco-engineering (Byers et al. 2006): Biobouwers of 'ecosystem engineers', zoals bevers die dammen bouwen en op die manier complete stromend water ecosystemen wijzigen. Binnen de eco-engineers worden verschillende typen onderscheiden, zoals bijvoorbeeld foundation species en bioturbators. Foundation species (Halpern et al. 2007) vormen het fundament van een ecosysteem, zoals vegetatie die habitatdiversiteit creëert en stroming en morfologie beïnvloedt. Foundation species zijn talrijk en nemen het grootste deel van de biomassa in, ze staan aan de basis van niet-trofische of mutualistische interacties in het ecosysteem (zoals riet in rietlanden). Ze bieden structuren voor andere soorten waardoor ze voedselwebben en energie en materie stromen door systemen veranderen. Bioturbators (Mermillod-Blondin \& Rosenberg 2006), zoals wormen en muggenlarven, woelen de waterbodem om. Dit wordt bioturberen genoemd. Een ander voorbeeld zijn brasems, deze vissen zijn bodemwoelers, in feite macro-bioturbators.

\subsection{Het 5-S-model}

Om een ecologische systeemanalyse van een oppervlaktewatersysteem uit te voeren is kennis nodig van (zie ook Hynes 1975, Allan \& Johnson 1997, Allan et al. 1998):

De ecologisch relevante factoren en -processen, de ecologische sleutelfactoren en -processen.

. De ruimtelijke en temporele schalen waarop deze factoren werkzaam zijn.

In de jaren negentig van de vorige eeuw is een eenvoudige indeling in vijf hoofdgroepen van milieufactoren voor oppervlaktewateren gepresenteerd: systeemvoorwaarden, hydrologische, morfologische, fysisch-chemische en biologische factoren (het 5-S-model; Verdonschot et al. 1995, 1998). Het 5-S-model kan gezien worden als een hulpmiddel en een vereenvoudigde benadering van het aquatische ecosysteem, zowel voor stromende als stilstaande wateren, waarin per hoofdgroep ecologisch relevante milieufactoren in een hiërarchie naar ruimtelijke en temporele schaal zijn ondergebracht (in lijn met eerdere hiërarchische indelingen voor terrestrische systemen: Van der Maarel \& Dauvellier 1978, Bakker et al. 1981, Piket 1987, Verdonschot et al. 1992, Klijn \& de Haes 1994, Johnson \& Gage 1997). De 5-S-en vervangen de STOWA ESF systematiek omdat de ESF-en verschillen tussen stromende en stilstaande wateren, ze niet eenduidig zijn gedefinieerd en van ongelijke orde zijn (bijvoorbeeld lopen stuur-, sleutel- en stressfactoren door elkaar heen).

De volgende paragrafen gaan dieper in op de relaties binnen iedere S. Veel meer mechanistische relaties zijn niet direct nodig om een ecologische systeemanalyse uit te voeren. Wel zijn extra relaties bij wijze van voorbeeld opgenomen, ter verduidelijking en om verdieping aan te brengen. 
Het ecologisch functioneren van een oppervlaktewater wordt in grote mate bepaald door de geografische ligging (regionale biogeografie) en het watertype. De lokale en regionale milieu-omstandigheden die het gevolg zijn van het klimaat (zoals tempera $\neg$ tuur en neerslag), de geologische ondergrond en bodem, de geomorfologische vorm (bijvoorbeeld hoogtever-schillen) en de geohydrologische en -chemische processen (bijvoorbeeld de kalkrijkdom en buffercapaciteit van grondwater) bepalen de omstandigheden waaronder soorten zijn geëvolueerd (biogeografische regio) en sturen waar soorten voor (kunnen) komen (o.a. Richards et al. 1996). Deze omstandigheden worden samen in het 5-S-model de 'Systeem(rand) voorwaarden' genoemd (Figuur 8.4).

De randvoorwaarden die de ecosysteemtoestand waarin een water zich bevindt bepalen de Systeemvoorwaarden. De systeemvoorwaarden spelen op een relatief grote ruimtelijke schaal, bijvoorbeeld hydro-ecologische eenheden in de vorm van fysisch-geografische of hydrobiologische districten. Daarnaast spelen ze ook op een relatief lange temporele schaal, waarbij gedacht moet worden aan decennia tot eeuwen.

\section{FIGUUR 8.4}

Interactieschema factorencomplex systeemvoorwaarden. In het kader staan de milieufactoren binnen deze hoofdgroep en hun onderlinge relaties, buiten het kader de verbindingen met andere groepen. Vetgedrukte begrippen in groen duiden ecologische sleutelfactoren aan.
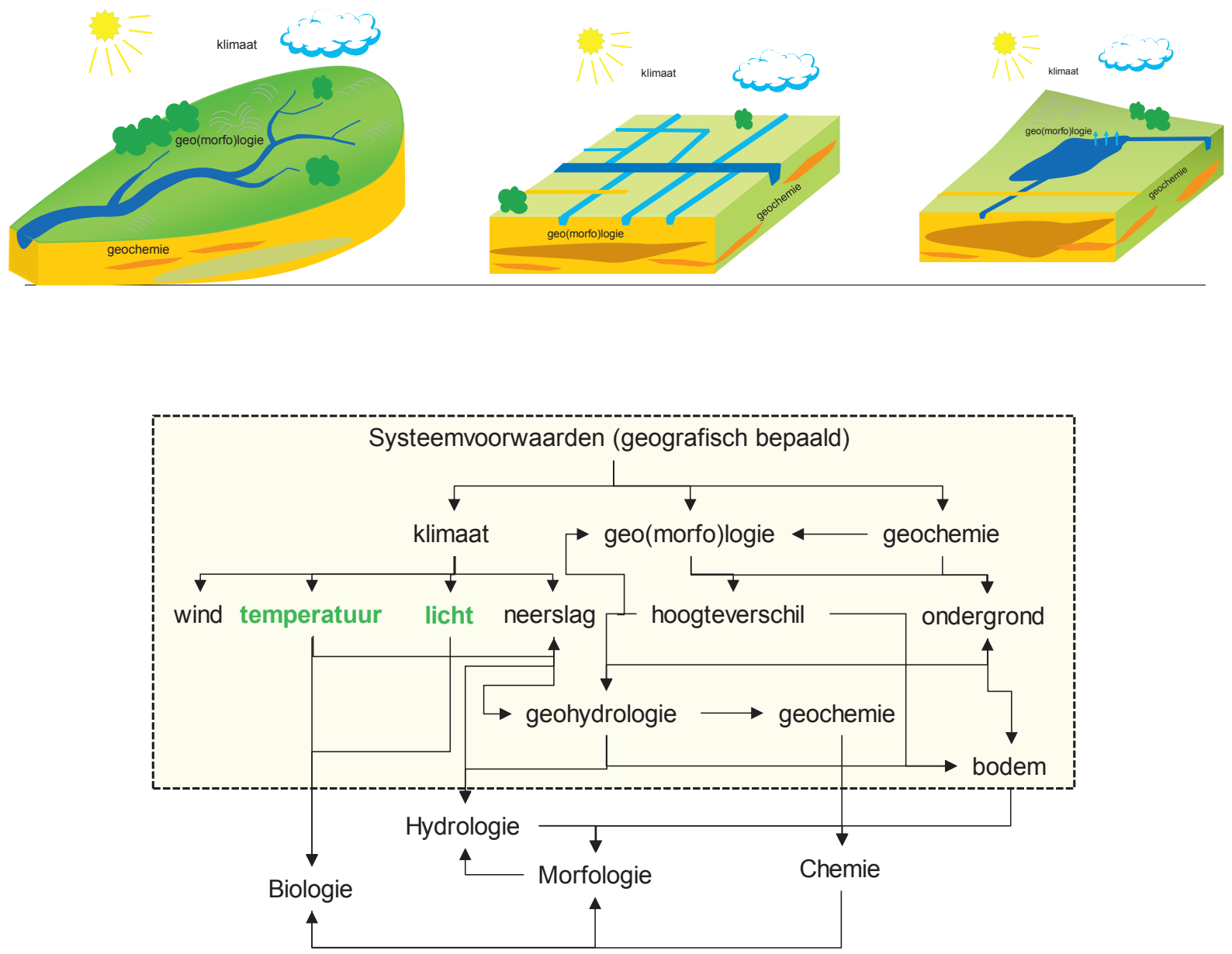
Het gedeelte hiervan waarbinnen het waterbeheer zich afspeelt kan worden omschreven als de "externe conditione $\neg$ rende ruimte”. De indeling van Nederlandse watertypen, zoals de aquatische natuurdoeltypen (Verdonschot 2000), de aquatische ecotooptypen (Verdonschot et al. 1992) of de minder gedetailleerde KRW-typologie (van der Molen et al. 2018) zijn hierop gebaseerd.

Direct met systeemvoorwaarden of -factoren samenhangend zijn de processen die tot de toestand van dergelijke factoren leiden of die de toestand van andere factoren bepalen. Tabel 8.4 geeft enkele voorbeelden hoe processen doorwerken in het 5-S-model van systeemvoorwaarden naar stroming (hydrologie), structuren (morfologie), stoffen (chemie) en soorten (biologie).

TABEL 8.4

Voorbeelden van de doorwerking van hoofdprocessen van systeemvoorwaarden op processen, werkingsschaal (ruimte en/of tijd) en belangrijkste ecologische sleutelfactoren. $H=$ hoog; $M=$ midden; $L=$ laag.

\begin{tabular}{|c|c|c|c|c|}
\hline Hoofdprocessen & 5-S & $\begin{array}{l}\text { Effect op } \\
\text { processen }\end{array}$ & Schaal & $\begin{array}{l}\text { Ecologische } \\
\text { sleutelfactor }\end{array}$ \\
\hline \multicolumn{5}{|l|}{$\begin{array}{l}\text { Klimatologische } \\
\text { processen }\end{array}$} \\
\hline \multirow[t]{2}{*}{ windwerking } & Hydrologie & $\begin{array}{l}\text { lichtregime } \\
\text { stratificatie } \\
\text { golfslag } \\
\text { resuspensie }\end{array}$ & $\begin{array}{l}\mathrm{H} \\
\mathrm{H} \\
\mathrm{M} \\
\mathrm{M}\end{array}$ & $\begin{array}{l}\text { licht } \\
\text { temperatuur } \\
\text { oevervorm, substraat } \\
\text { licht }\end{array}$ \\
\hline & Chemie & salt-spray & $M$ & chloride \\
\hline \multirow[t]{3}{*}{ opwarming/afkoeling } & Hydrologie & $\begin{array}{l}\text { verdamping } \\
\text { condensatie }\end{array}$ & $\begin{array}{l}\mathrm{H} \\
\mathrm{H}\end{array}$ & $\begin{array}{l}\text { temperatuur } \\
\text { temperatuur }\end{array}$ \\
\hline & Chemie & zuurstofregime & $M / L$ & zuurstof \\
\hline & Biologie & $\begin{array}{l}\text { thermofilie } \\
\text { fenologie }\end{array}$ & $\begin{array}{l}\mathrm{H} \\
\mathrm{H}\end{array}$ & $\begin{array}{l}\text { temperatuur } \\
\text { temperatuur }\end{array}$ \\
\hline \multirow[t]{2}{*}{ neerslagregime } & Hydrologie & $\begin{array}{l}\text { afvoerregime } \\
\text { runoff } \\
\text { peildynamiek } \\
\text { waterbeweging } \\
\text { inundatie } \\
\text { stagnatie } \\
\text { droogval } \\
\text { stratificatie }\end{array}$ & $\begin{array}{l}\mathrm{H} \\
\mathrm{M} \\
\mathrm{H} \\
\mathrm{H} / \mathrm{M} \\
\mathrm{H} \\
\mathrm{H} \\
\mathrm{H}\end{array}$ & $\begin{array}{l}\text { stroming } \\
\text { nutriënten } \\
\text { droogval, diepte } \\
\text { stroming } \\
\text { droogval } \\
\text { stroming, zuurstof } \\
\text { droogval } \\
\text { temperatuur }\end{array}$ \\
\hline & Chemie & zoute kwel & & chloride \\
\hline lichtregime & Biologie & $\begin{array}{l}\text { dag-nacht ritme } \\
\text { groeisnelheid } \\
\text { zuurstofproductie } \\
\end{array}$ & & $\begin{array}{l}\text { levensstrategie } \\
\text { levensstrategie } \\
\text { zuurstof }\end{array}$ \\
\hline \multicolumn{5}{|l|}{$\begin{array}{l}\text { Geo(morfo)logische } \\
\text { processen }\end{array}$} \\
\hline erosie & Morfologie & $\begin{array}{l}\text { profielvorming } \\
\text { egalisering }\end{array}$ & $\begin{array}{l}M \\
M\end{array}$ & $\begin{array}{l}\text { substraat } \\
\text { stroming, substraat }\end{array}$ \\
\hline sedimentatie & Morfologie & aanslibbing & $M$ & substraat \\
\hline bodemvorming & Morfologie & $\begin{array}{l}\text { bodemopbouw } \\
\text { doorlatendheid }\end{array}$ & $\begin{array}{l}\mathrm{H} \\
\mathrm{H}\end{array}$ & $\begin{array}{l}\text { substraat } \\
\text { droogval }\end{array}$ \\
\hline \multicolumn{5}{|l|}{$\begin{array}{l}\text { Geochemische } \\
\text { processen }\end{array}$} \\
\hline kalkoplosbaarheid & Chemie & grondwaterhardheid & $\mathrm{H} / \mathrm{M}$ & macro-ionen, zuurgraad \\
\hline
\end{tabular}


Met Stroming wordt in het 5-S-model gerefereerd aan de hydrologie van het grond- en oppervlaktewater. De hydrologie is in zowel stilstaande als stromende wateren de meest bepalende factor of factorcomplex. Op een hoger ruimtelijk en temporeel schaalniveau speelt de regionale grond- en oppervlaktewaterhydrologie zich af, met neerslag en verdam $\neg$ ping, afvoer en grondwaterstro $\neg$ ming, infiltratie en kwel als belangrijke factoren en processen (o.a. Poff \& Ward 1989). Op lokale schaal spelen lokale afstroming (run-off), verblijftijd, stratificatie, een belangrijke rol. Daarnaast is op deze schaal ook de hydraulica van belang, die factoren en processen omvat zoals waterpeilen, waterbeweging, debiet en stroomsnelheid. In figuur 8.5 wordt de samenhang tussen verschillende factoren binnen de hoofdgroep ‘stroming' weergegeven.

Direct met hydrologische factoren samenhangend zijn de processen die tot de toestand van dergelijke factoren leiden of die de toestand van andere factoren bepalen. Tabel 8.5 geeft enkele voorbeelden hoe processen doorwerken in het 5-S-model van hydrologie naar hydrologie, morfologie, chemie en biologie.

\section{FIGUUR 8.5}

Interactieschema stroming (grond- en oppervlaktewaterhydrologie-hydraulica). In het kader staan de milieufactoren binnen de hoofdgroep en hun onderlinge relaties, buiten het kader de verbindingen met andere groepen. Vetgedrukte begrippen in groen duiden ecologische sleutelfactoren aan.
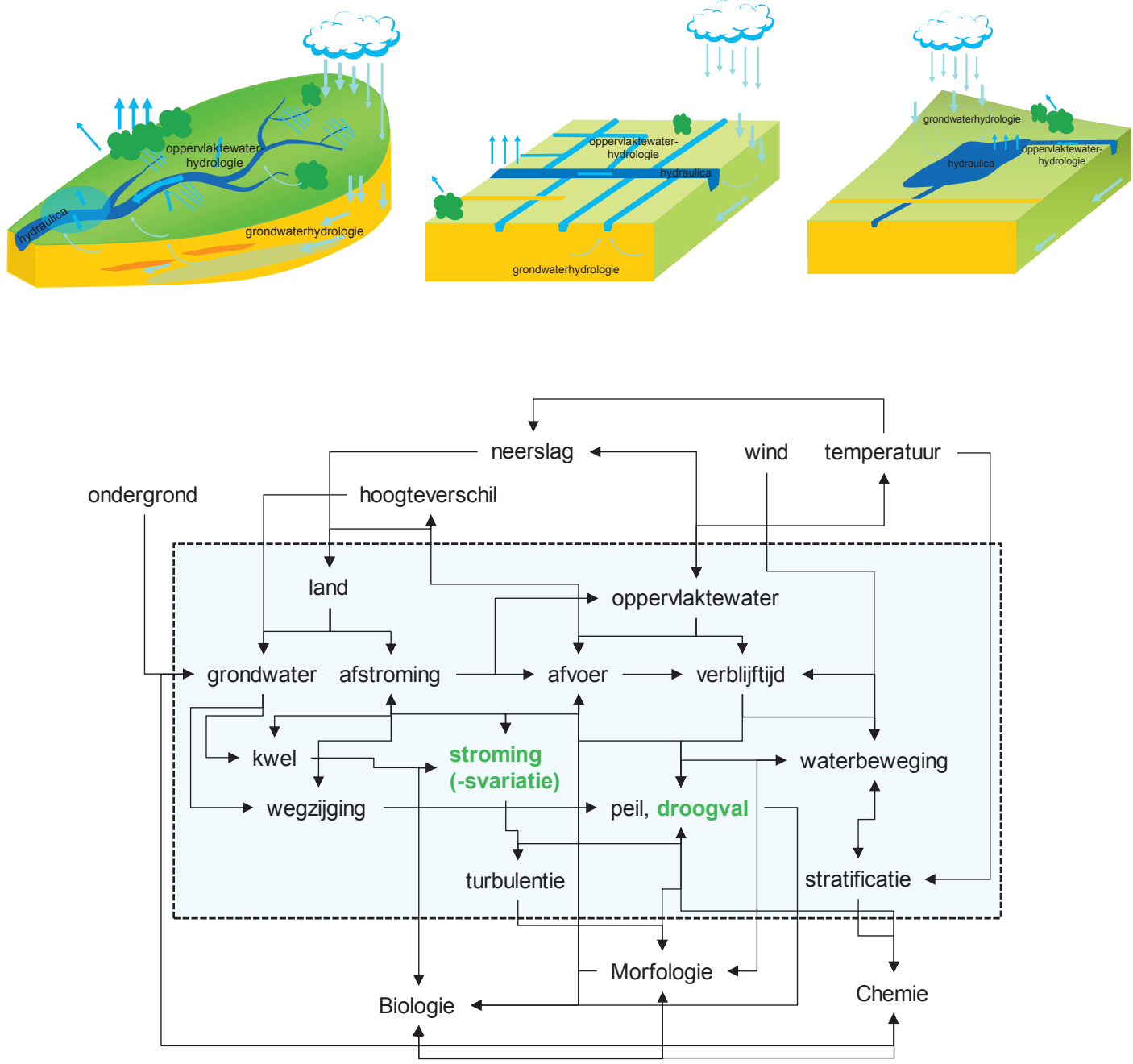
TABEL 8.5

Voorbeelden van de doorwerking van hydrologische hoofdprocessen op processen, werkingsschaal en belangrijkste ecologische sleutelfactoren. $H=$ hoog; $M=$ midden; $L=$ laag.

\begin{tabular}{|c|c|c|c|c|}
\hline Hoofdprocessen & $5-5$ & $\begin{array}{l}\text { Effecten op } \\
\text { processen }\end{array}$ & Schaal & $\begin{array}{l}\text { Ecologische } \\
\text { sleutelfactor }\end{array}$ \\
\hline \multicolumn{5}{|l|}{$\begin{array}{l}\text { Grondwater- } \\
\text { processen }\end{array}$} \\
\hline grondwaterstroming & Hydrologie & afvoerregime & $\mathrm{H}$ & stroming \\
\hline \multirow[t]{2}{*}{ infiltratie-kwel } & Hydrologie & $\begin{array}{l}\text { droogval } \\
\text { inundatie } \\
\text { peildynamiek } \\
\end{array}$ & $\begin{array}{l}\mathrm{H} \\
\mathrm{H} \\
\mathrm{H} \\
\end{array}$ & $\begin{array}{l}\text { droogval } \\
\text { droogval } \\
\text { droogval } \\
\end{array}$ \\
\hline & Chemie & ionenhuishouding & $\mathrm{H} / \mathrm{M}$ & macro-ionen \\
\hline \multicolumn{5}{|l|}{$\begin{array}{l}\text { Oppervlaktewater- } \\
\text { processen }\end{array}$} \\
\hline \multirow[t]{2}{*}{ afvoerregime } & Hydrologie & $\begin{array}{l}\text { turbulentie } \\
\text { waterbeweging } \\
\text { stagnatie } \\
\text { inundatie }\end{array}$ & $\begin{array}{l}\mathrm{H} / \mathrm{M} \\
\mathrm{H} / \mathrm{M} \\
\mathrm{H} \\
\mathrm{H}\end{array}$ & $\begin{array}{l}\text { stroming } \\
\text { stroming } \\
\text { stroming, zuurstof } \\
\text { droogval }\end{array}$ \\
\hline & Morfologie & $\begin{array}{l}\text { erosie } \\
\text { sedimentatie }\end{array}$ & $M$ & $\begin{array}{l}\text { substraat } \\
\text { substraat }\end{array}$ \\
\hline \multirow[t]{3}{*}{ peildynamiek } & Hydrologie & $\begin{array}{l}\text { inundatieregime } \\
\text { droogval }\end{array}$ & $\begin{array}{l}\mathrm{H} \\
\mathrm{H} \\
\end{array}$ & $\begin{array}{l}\text { droogval, diepte } \\
\text { droogval }\end{array}$ \\
\hline & & $\begin{array}{l}\text { zoute kwel } \\
\text { indamping }\end{array}$ & $\begin{array}{l}\mathrm{H} \\
\mathrm{H} \\
\end{array}$ & $\begin{array}{l}\text { macro-ionen (chloride) } \\
\text { macro-ionen }\end{array}$ \\
\hline & Morfologie & resuspensie & $M$ & licht \\
\hline \multicolumn{5}{|l|}{$\begin{array}{l}\text { Hydraulische } \\
\text { processen }\end{array}$} \\
\hline & Hydrologie & $\begin{array}{l}\text { waterbeweging } \\
\text { stratificatie }\end{array}$ & $\begin{array}{l}\mathrm{L} \\
\mathrm{L} / \mathrm{M}\end{array}$ & $\begin{array}{l}\text { stroming, substraat } \\
\text { temperatuur }\end{array}$ \\
\hline & Morfologie & turbulentie & $M / L$ & substraat, stroming \\
\hline
\end{tabular}

\subsubsection{Structuren}

De Structuren in het 5-S-model omvatten de morfologie. Stroming en structuren interacteren met elkaar op verschillende schalen in tijd en ruimte. Zo hebben de regionale grond- en oppervlaktewaterstromen effect op de heterogeniteit van het landschap, de biotopen en het habitat, zoals de ontwikkeling van het lengteprofiel (het tracé), dwarsprofiel (de bedding), het transport van materiaal, vegetatie $\neg$ structuren, oevervorm en bodemstructuur en -sortering (bijvoorbeeld de reeks grind-zand-detritus-slib bij afnemende stroomsnelheid) in stromende wateren, en de oevervorm en bodemsamenstelling in stilstaande wateren (o.a. Frissell et al. 1986, Poff \& Ward 1990).

Omgekeerd beïnvloeden de structuren in het landschap, de ondergrond en de watersystemen weer de waterstromen. In stromende wateren bepalen lokale (grond-)waterstromen voor een belangrijk deel het ontstaan en verdwijnen van de habitatheterogeniteit en substraatmozaïeken zoals blad $\neg$ pakketten, zand- en grindban $\neg k e n$ en depositiezones met detritus. De begroeiing langs een beek en de vorm, breedte en diepte van het profiel bepalen de substraatheterogeniteit. Substraten zoals ingevallen bomen en takken beïnvloeden weer de stroming. In stilstaande wateren is het vooral de wind die water in beweging zet, substraat verplaatst en oevers erodeert. Verlanding gaat deze erosie weer tegen. Waterbeweging leidt samen met kwel- en infiltratiestromen in alle typen oppervlakte`waᄀteren tot heterogeniteit. Waterbeweging kan ook leiden tot het in de waterkolom geraken van deeltjes waardoor de helderheid afneemt. De diepte van stilstaande wateren bepaalt in samenhang met de hoeveelheid deeltjes in de waterkolom (licht) de kansen voor de ontwikkeling van waterplanten. Waterplanten vormen zelf weer structuren voor fauna en over lange tijd kunnen water- en oeverplanten stilstaande wateren veranderen in moerassen (verlanding). In figuur 8.6 wordt de samenhang tussen de verschillende factoren en processen binnen de hoofdgroep 'structuren' weergegeven. 


\section{FIGUUR 8.6}

Interactieschema structuren. In het kader staan de milieufactoren binnen de hoofdgroep en hun onderlinge relaties, buiten het kader de verbindingen met andere groepen. Vetgedrukte begrippen in groen duiden ecologische sleutelfactoren aan.
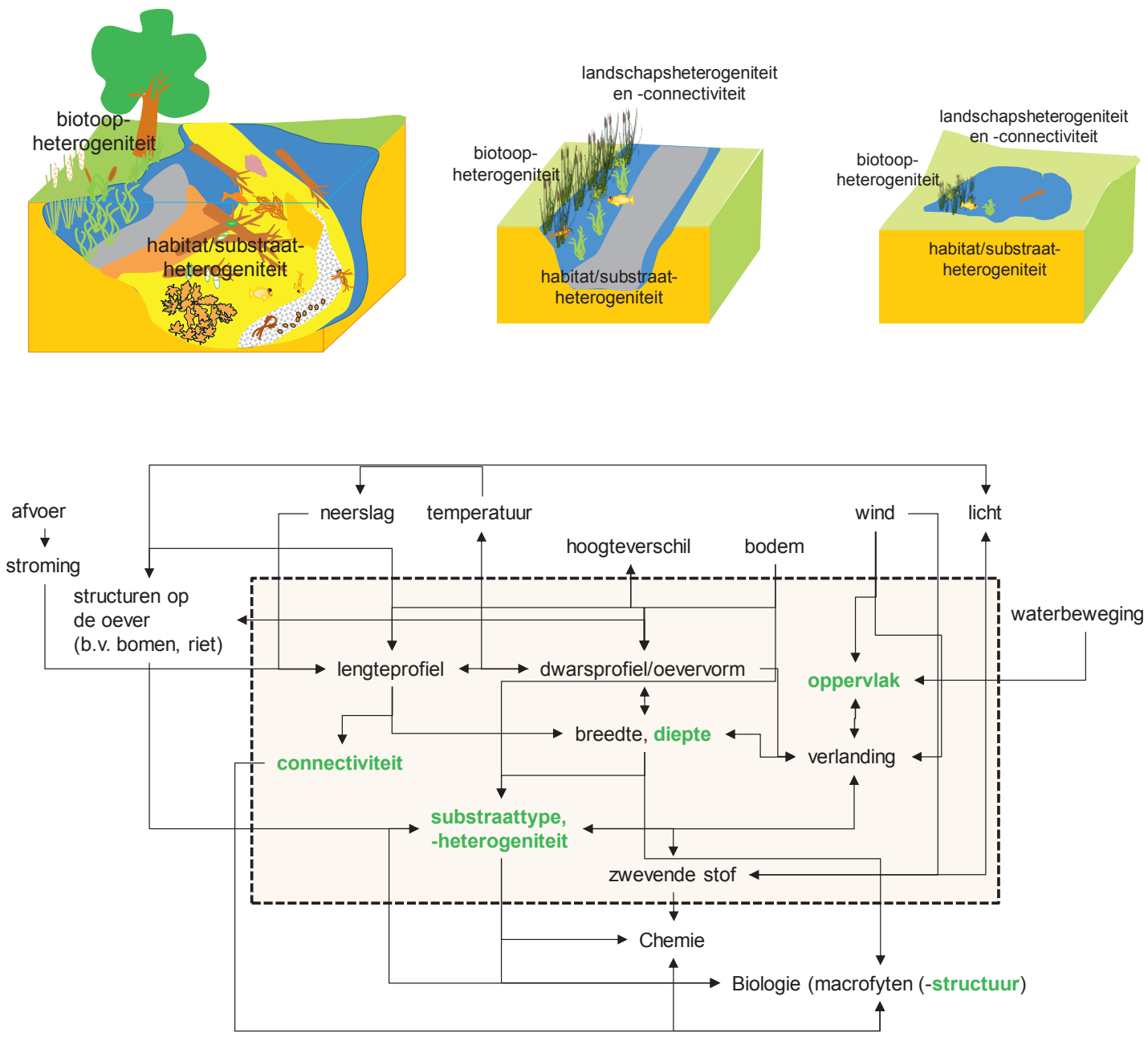

Direct met morfologische factoren samenhangend zijn de processen die tot de toestand van dergelijke factoren leiden of die de toestand van andere factoren bepalen. Tabel 8.6 geeft enkele voorbeelden hoe processen doorwerken in het 5-S-model van structuren (morfologie) naar stroming (hydrologie), structuren zelf (morfologie), stoffen (chemie) en soorten (biologie). 
TABEL 8.6

Voorbeelden van de doorwerking van morfologische hoofdprocessen op processen, werkingsschaal en belangrijkste ecologische sleutelfactoren. $H=$ hoog; $M=$ midden; $L=$ laag.

\begin{tabular}{|c|c|c|c|c|}
\hline Hoofdprocessen & $5-5$ & $\begin{array}{l}\text { Effecten op } \\
\text { processen }\end{array}$ & Schaal & $\begin{array}{l}\text { Ecologische } \\
\text { sleutelfactor }\end{array}$ \\
\hline \multicolumn{5}{|l|}{ Vormprocessen } \\
\hline \multirow[t]{2}{*}{ loopontwikkeling } & Hydrologie & $\begin{array}{l}\text { stroming } \\
\text { stromingsdynamiek }\end{array}$ & $\begin{array}{l}H / M \\
M / L\end{array}$ & $\begin{array}{l}\text { stroming } \\
\text { stroming }\end{array}$ \\
\hline & Morfologie & $\begin{array}{l}\text { profielontwikkeling } \\
\text { taludontwikkeling } \\
\text { erosie } \\
\text { sedimentatie } \\
\text { connectiviteit }\end{array}$ & $\begin{array}{l}M \\
M \\
M\end{array}$ & $\begin{array}{l}\text { substraat } \\
\text { substraat } \\
\text { substraat } \\
\text { substraat }\end{array}$ \\
\hline oeverontwikkeling & Morfologie & substraatdynamiek & $M / L$ & substraat \\
\hline \multicolumn{5}{|l|}{ Substraatprocessen } \\
\hline substraatvorming & Morfologie & substraatdynamiek & $\mathrm{L}$ & substraat \\
\hline substraatdynamiek & Morfologie & substraatdynamiek & $\mathrm{L}$ & substraat \\
\hline \multicolumn{5}{|l|}{ Structuurprocessen } \\
\hline plantengroei & Morfologie & substraatvorming & $M / L$ & substraat \\
\hline \multirow{3}{*}{ verlanding } & Morfologie & substraatvorming & & substraat \\
\hline & Chemie & $\begin{array}{l}\text { saprobiëring } \\
\text { zuurstofregime }\end{array}$ & & $\begin{array}{l}\text { organisch materiaal, } \\
\text { ammonium } \\
\text { zuurstof }\end{array}$ \\
\hline & Biologie & waterplantenontwikkeling & $M$ & macrofytenstructuur \\
\hline \multicolumn{5}{|l|}{ Connectiviteit } \\
\hline \multirow{2}{*}{ verbinding/fragmentatie } & Morfologie & sedimenttransport & $M$ & substraat \\
\hline & Biologie & migratie, dispersie & & connectiviteit \\
\hline \multirow[t]{2}{*}{ isolatie } & Hydrologie & $\begin{array}{l}\text { waterbeweging, } \\
\text { stratificatie }\end{array}$ & & $\begin{array}{l}\text { stroming, substraat } \\
\text { temperatuur }\end{array}$ \\
\hline & Biologie & populatie-ontwikkeling & & connectiviteit \\
\hline
\end{tabular}

\subsubsection{Stoffen}

De regionale (grond-)waterstromen hebben effect op de stofstromen (de fysisch-chemische as $\neg$ pecten) en de chemische processen; de Stoffen in het 5-S-model. De stoffen, al dan niet gebonden aan deeltjes, "liften" als het ware mee met het water en vormen gradiënten afhankelijk van de (grond-)waterstromen die ze op hun weg tegenkomen (bijvoorbeeld kalkrijke bodemlagen of transport van organisch materiaal van oeverzone naar waterkolom). Het 'Nutrient Spiralling Concept' (Newbold et al. 1982) en het 'River Continuum Concept' (Vannote et al. 1980) geven een duidelijke omschrijving van deze graduele processen. Voor alle wateren geldt dat op regionale schaal macro-ionen een belangrijke rol spelen (afhankelijk van de herkomst van het water), evenals de organisch-materiaal-cyclus die de aanvoer en afbraak van organisch materiaal beschrijft. Op lokale schaal spelen fysisch-chemische processen zoals het verloop van het zuurstofgehalte, de afbraak van organisch materiaal en de opname en afgifte van voedingsstof $\neg$ fen (o.a. Verhoeven et al. 2007, Johnson et al. 2007, Jeppesen et al. 2000). In figuur 8.7 wordt de samenhang tussen verschillende factoren binnen de hoofdgroep 'stoffen' weergegeven.

Direct met chemische factoren samenhangend zijn de processen die tot de toestand van dergelijke factoren leiden of die de toestand van andere factoren bepalen. Tabel 8.7 geeft enkele voorbeeld hoe processen doorwerken in het 5-S-model van chemie naar chemie en biologie. 


\section{FIGUUR 8.7}

Interactieschema stoffen. In het kader staan de milieufactoren binnen de hoofdgroep en hun onderlinge relaties, buiten het kader de verbindingen met andere groepen. Vetgedrukte begrippen in groen duiden ecologische sleutelfactoren aan.
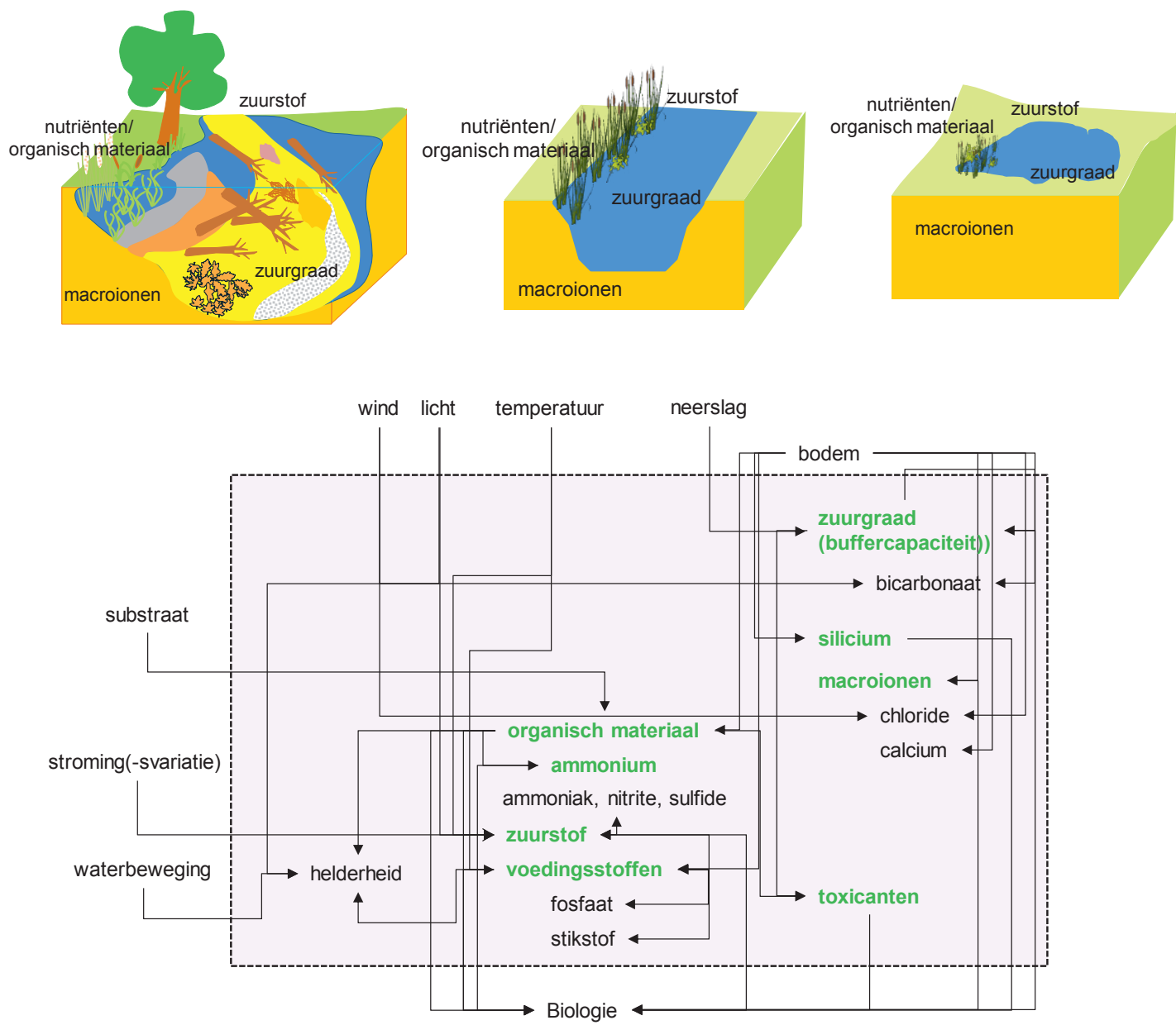

TABEL 8.7

Voorbeelden van de doorwerking van chemische hoofdprocessen op processen, werkingsschaal en belangrijkste ecologische sleutelfactoren.

\begin{tabular}{|l|l|l|l|l|}
\hline Hoofdprocessen & 5-S & $\begin{array}{l}\text { Effecten op } \\
\text { processen }\end{array}$ & Schaal & $\begin{array}{l}\text { Ecologische } \\
\text { sleutelfactor }\end{array}$ \\
\hline $\begin{array}{l}\text { Chemische } \\
\text { processen }\end{array}$ & & & & \\
\hline verzuring & Chemie & zuur-base evenwicht & $\mathrm{H} / \mathrm{M}$ & zuurgraad \\
\hline alkalinisering & Chemie & zuur-base evenwicht & $\mathrm{H} / \mathrm{M}$ & zuurgraad \\
\hline verharding & Chemie & ionenhuishouding & $\mathrm{H} / \mathrm{M}$ & macro-ionen \\
\hline verzachting & Chemie & ionenhuishouding & $\mathrm{H} / \mathrm{M}$ & macro-ionen \\
\hline (de-)saprobiëring & Chemie & $\begin{array}{l}\text { decompositie, } \\
\text { zuurstofregime }\end{array}$ & $\mathrm{H} / \mathrm{M}$ & $\begin{array}{l}\text { zuurstof, ammonium, } \\
\text { organisch materiaal }\end{array}$ \\
\hline (de-)eutrofiëring & Chemie & nutriëntenhuishouding & $\mathrm{H} / \mathrm{M}$ & $\begin{array}{l}\text { voedingsstoffen, } \\
\text { organisch materiaal }\end{array}$ \\
\hline vergiftiging & Chemie & toxiciteit & $\mathrm{H} / \mathrm{M}$ & gifstoffen \\
\hline
\end{tabular}


Verschillen in milieufactoren zorgen voor variatie in levensom $\neg$ standighe $\neg$ den voor organismen in het watersysteem. De organis $\neg$ men en de ge $\neg$ meenschappen waar ze deel van uitmaken worden aangeduid met de term soorten (Figuur 8.8). Soorten zijn vooral responsvariabelen, die reageren op de patronen en processen in milieufactoren stroming, structuren en stoffen. Echter, sommige soorten oefenen zelf invloed uit op de milieufactoren, wat ze sturend maakt. Daarnaast reageren soorten ook op elkaar, de biotische interacties, bijvoorbeeld via predatie, competitie en concurrentie, wat voor sommige soorten net zo belangrijk kan zijn als de respons op het milieu.

\section{FIGUUR 8.8}

Interactieschema soorten. In het kader staan de milieufactoren binnen de hoofdgroep en hun onderlinge relaties, buiten het kader de verbindingen met andere groepen. Vetgedrukte begrippen in groen duiden ecologische sleutelfactoren aan.

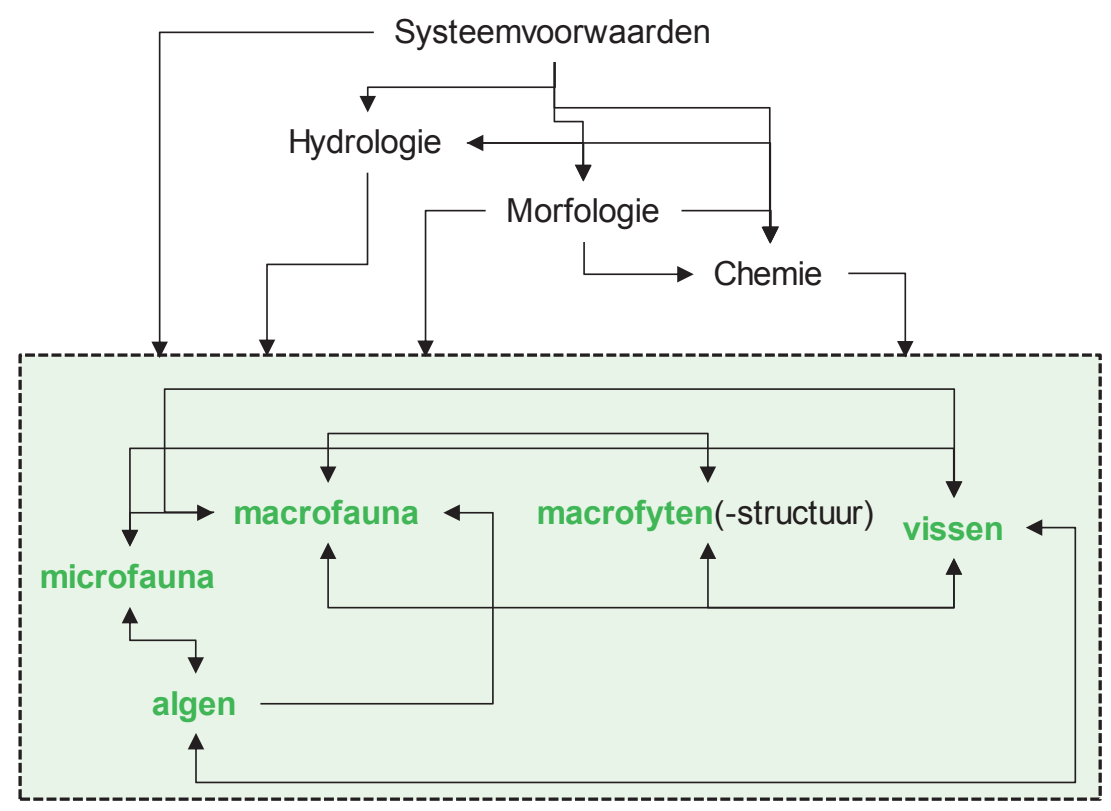

Direct met biologische factoren samenhangend zijn de processen die tot de toestand van dergelijke factoren leiden, of die de toestand van andere factoren bepalen. Tabel 8.8 geeft enkele voorbeelden hoe processen doorwerken in het 5-S-model van biologie naar morfologie, chemie en biologie.

Samenvattend ziet het 5-S-model eruit als in figuur 8.9. 
TABEL 8.8

Voorbeelden van de doorwerking van biologische hoofdprocessen op processen en werkingsschaal.

\begin{tabular}{|c|c|c|c|c|}
\hline Hoofdprocessen & 5-S & $\begin{array}{l}\text { Effecten op } \\
\text { processen }\end{array}$ & Schaal & $\begin{array}{l}\text { Ecologische } \\
\text { responsfactor }\end{array}$ \\
\hline \multicolumn{5}{|l|}{ Abiotische processen } \\
\hline Verstoring & $\begin{array}{l}\text { Hydrologie } \\
\text { Morfologie } \\
\text { Chemie } \\
\text { Biologie }\end{array}$ & $\begin{array}{l}\text { weerstand en } \\
\text { veerkracht }\end{array}$ & & $\begin{array}{l}\text { alle groepen gevoelig } \\
\text { voor invasiviteit }\end{array}$ \\
\hline \multicolumn{5}{|l|}{ Stromingsprocessen } \\
\hline Doorstroming & & uitwisseling & $M / L$ & connectiviteit \\
\hline \multicolumn{5}{|l|}{ Biologische processen } \\
\hline Productie-decompositie & $\begin{array}{l}\text { Morfologie } \\
\text { Chemie } \\
\text { Biologie }\end{array}$ & voedselweb & $M / L$ & alle groepen \\
\hline Concurrentie & $\begin{array}{l}\text { Morfologie } \\
\text { Chemie } \\
\text { Biologie }\end{array}$ & voedselweb, habitat & $M$ & alle groepen \\
\hline Successie & $\begin{array}{l}\text { Morfologie } \\
\text { Chemie } \\
\text { Biologie }\end{array}$ & $\begin{array}{l}\text { bodemontwikkeling } \\
\text { macrofytengroei }\end{array}$ & $M / L$ & $\begin{array}{l}\text { substraat, organisch } \\
\text { materiaal } \\
\text { zuurstof } \\
\text { alle groepen }\end{array}$ \\
\hline & Biologie & diversificering & $M / L$ & alle groepen \\
\hline
\end{tabular}

\section{FIGUUR 8.9}

Het 5-S-model met abiotische en biotische milieufactoren.

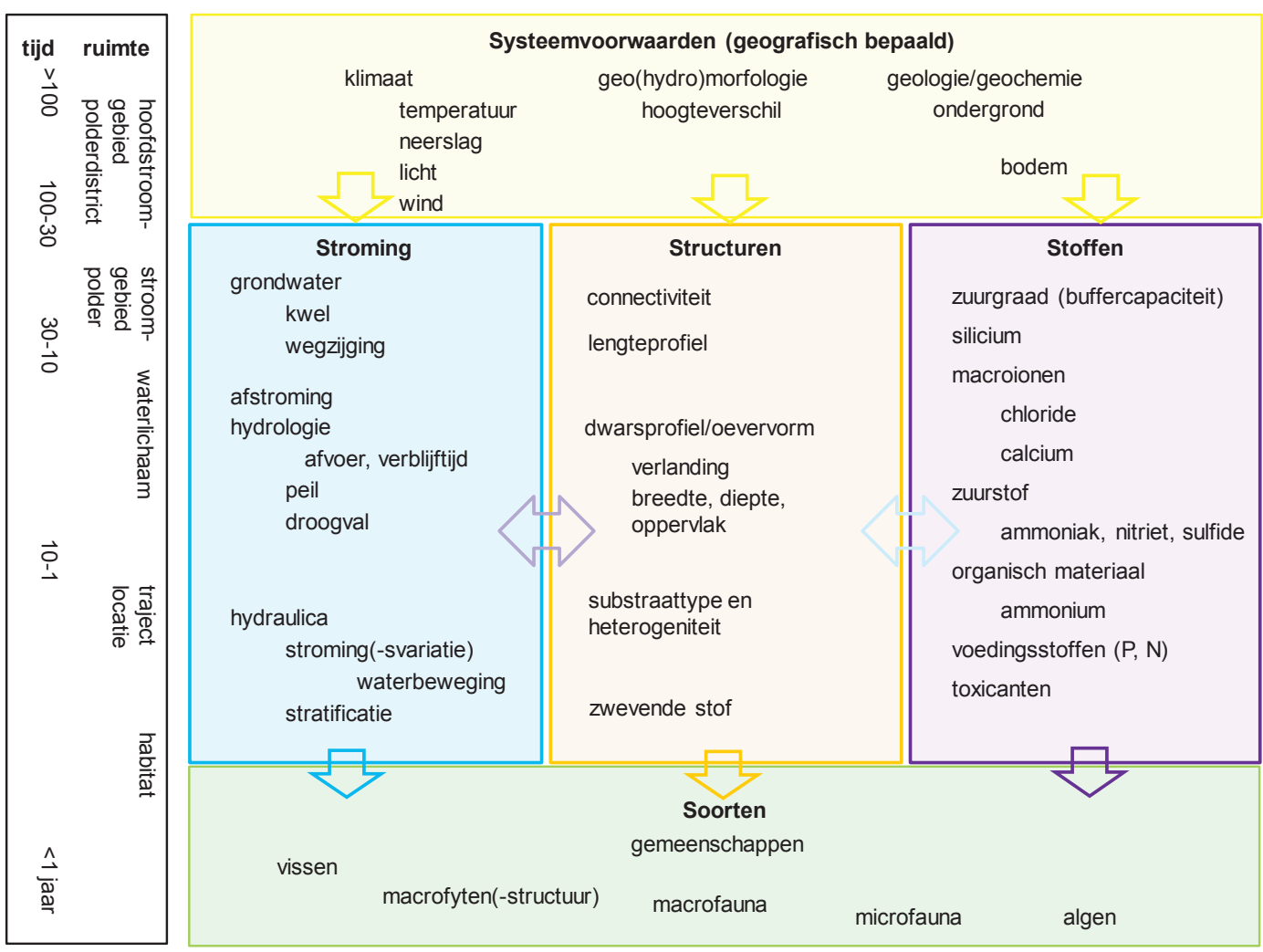




\subsection{Ruimtelijke en temporele schalen}

Processen werken op verschillende schalen in ruimte en tijd en dat betekent dat factoren op betreffende schalen kunnen worden geprojecteerd (Figuur 8.9; Levin 1992, Chave 2013). Zo werken bijvoorbeeld geologische processen over een zeer lange geologische tijdschaal, terwijl sommige biochemische processen binnen enkele seconden verlopen (Delcourt et al. 1982, Magnuson 1990, Leveque 2003). Voor het waterbeheer is een ruimtelijke schaal van stroomgebied-polder-waterbeheereenheid tot locatie of habitat en een temporele schaal van enkele tientallen jaren tot maanden, weken of dagen van belang. Daarnaast is de responsschaal van organismen belangrijk. Diatomeeën en algen functioneren op een relatief kleine ruimtelijke en korte temporele schaal, macrofyten op een kleinere tot grotere ruimtelijke en langere tot lange temporele schaal, macrofauna op middelgrote ruimtelijke en middellange temporele schaal en vissen op een grote ruimtelijke en langere temporele schaal. Per soort(groep) kan de ruimtelijke en temporele schaal echter aanzienlijk verschillen. Er zijn voorbeelden bekend voor o.a. algen (Stevenson et al. 1996), macrofyten (Alahuhta 2014), macrofauna (Parsons et al. 2004) en vissen (Tonn 1990). De relaties tussen schaal enerzijds en de werking van sleutel- en stuurfactoren anderzijds is van groot belang in systeemanalyses.

\subsection{DPSIRR}

Het doel van het ecologisch raamwerk is het geven van een onderbouwing aan de keuze van de (kosten-)effectieve en alle in samenhang probleemoplossende maatregelen (compleetheid van maatregelen). Om dit doel te bereiken is kennis nodig van die sleutelfactoren en achterliggende sleutelprocessen die direct het functioneren van het ecosysteem bepalen. Verder is het van belang de maatregelen te kunnen selecteren die daadwerkelijke verbeteringen bewerkstelligen. Een hulpmiddel hierbij zijn de zogenaamde DPSIRR-ketens.

Menselijke activiteiten in een stroomgebied kunnen druk uitoefenen op wateren en bepalen daarmee de toestand van het water. Dit heeft gevolgen voor het waterecosysteem, wat leidt tot een maatschappelijke reactie, die vervolgens weer tot uiting komt in maatregelen. Om de interacties tussen de menselijke activiteiten en het milieu te structureren is de DPSIR-keten (EEA 1995) ontwikkeld, die later uitgebreid is tot de DPSIRR-keten (Feld et al. 2011). DPSIRR staat voor: Driving forces (=menselijke activiteiten) - Pressures/Stressors (=druk-/stressfactoren) - State (=toestand van ecosysteem) - Impact (=gevolgen voor ecosysteem (functioneren) en ecosysteemdiensten) - Responses (=menselijke reactie in de vorm van maatregelen) - Recovery (=herstel van het ecosysteem) (Figuur 8.10).

Met de DPSIRR-keten wordt de keten tussen oorzaak van een stressor en het gevolg ervan, het effect op het ecosysteem, in beeld gebracht. Voor het kiezen van maatregelen is begrip van deze keten noodzakelijk. Het inzicht hebben in en het begrijpen van de gehele keten biedt mogelijkheden om op verschillende plaatsen in de keten in te grijpen om de effecten op te heffen of te verminderen, m.a.w. maatregelen te treffen. Dit kunnen maatregelen zijn om de bron of 'driver' aan te pakken (het begin van de keten), effectgerichte maatregelen of maatregelen die de effecten verkleinen (het einde van de keten, 'end-of-pipe').

DPSIRR vormt de basis voor een systematische en praktische benadering om ecologische systeemanalyses over verschillende relevante schalen in ruimte en tijd uit te voeren. Maatregelen zijn sturende menselijke activiteiten die de toestand van het waterecosysteem veranderen met als (gewenst) effect: herstel van het ecosysteem of onderdelen hiervan. Bijvoorbeeld landbouwkundig landgebruik (Driver) leidt tot afspoelen van fosfaat (Pressure/Stressor) met als gevolg voedselrijk water met blauwalgenbloei (Impact) waar bijvoorbeeld op wordt ingegrepen door de aanleg van bufferzones (Response) wat kan leiden tot helder water (Recovery). 


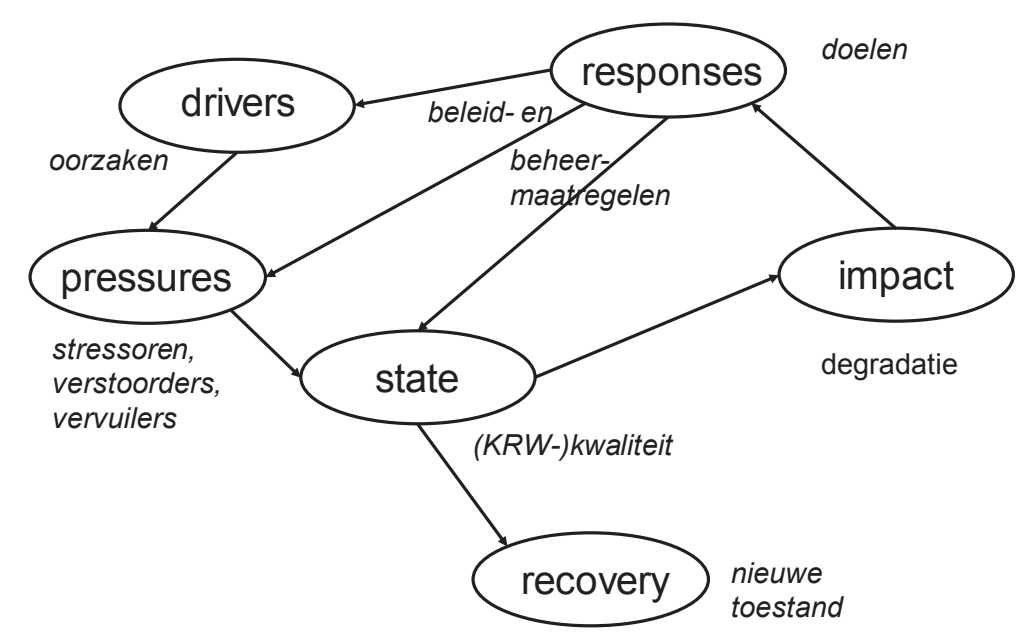

Voor de toepassing van de DPSIRR-keten in de praktijk is het nodig om de relaties binnen de geografische positie en het watertype (systeemvoorwaarden) om te zetten in relevante factoren die achterliggende patronen en processen representeren binnen de hoofdgroepen stroming, structuren en stoffen, telkens gekoppeld aan de biologie (organismengroepen; soorten). De interactie tussen factoren en processen binnen en tussen de schaalniveaus is in iedere keten aanwezig, maar verschilt tussen ketens in hiërarchische positie en intensiteit. Met andere woorden, het belang van factoren verschilt en is afhankelijk van geografische positie en watertype en van de range van milieufactoren. Het kennen van de relevantie (hiërarchie en intensiteit) voor het betreffende ecosysteem kan in hoge mate bijdragen aan de selectie of prioritering van de meest kosteneffectieve maatregelen. 


\section{HET MACROSYSTEEM}

\subsection{Geografische eenheden (districten) en watertypen}

De verspreiding en abundantie van soorten is niet homogeen verdeeld, zelfs binnen de relatief kleine oppervlakte van Nederland. Grootschalige biogeografische verschillen worden in belangrijke mate veroorzaakt door verschillen in systeemvoorwaarden (Mennema 1978). Klimatologische verschillen tussen het noorden en zuiden van Nederland, de invloed van de zee door zoute kwel en 'salt-spray', de invloed van de laagveenbodem op de substraatstructuur en het organisch stofgehalte, de invloed van hoogteverschillen op de stroomsnelheid zijn voorbeelden van belangrijke sturende systeemvoorwaarden of landschapskenmerken op de verspreiding van soorten. Om deze reden zijn in het verleden hydrobiologische districten gedefinieerd (Mol 1985, 1986). De 36 hydrobiologische districten zijn op basis van de geomorfologie in zeven hoofdgroepen te verdelen: Reliëfrijke districten, Hoger gelegen zandgronden, Hoogveengebieden, Lager gelegen zoete zand- en kleigebieden, Brakke klei- en veengebieden, Grote rivieren, en Zuidelijke IJsselmeerpolders (Figuur 9.1).

Daarnaast verklaart ook de indeling van oppervlaktewateren naar watertypen voor een deel de variatie in soortensamenstelling van macrofauna, vissen, macrofyten en diatomeeën. Het watertype wordt zelf in belangrijke mate gedefinieerd door hydrologische (verval, stroomsnelheid, droogval), morfologische (dimensies, habitat/substraatheterogeniteit en oevervorm) en chemische (chloride, zuurgraad) factoren (o.a. CUWVO 1986). Een voorbeeld van een hiërarchische indeling op basis van ecologische sleutelfactoren wordt in figuur 9.2 gegeven (van der Hoek et al. 1994).

Er zijn internationaal, nationaal en regionaal veel typologieën ontwikkeld, die vaak gebruik maken van verschillende criteria waarop ze wateren indelen. Voorbeelden zijn de merentypologie, CUWVO-typologie, KRW-typologie, Aquatische Natuurdoeltypen, cenotypologieën voor Limburg, Overijssel, en Gelderland en de cenotypologie duinwateren. In de ecologische systeemanalyse is het gebruik van een ecologische watertypologie een geschikt hulpmiddel om onder meer het belang van milieufactoren te duiden en om streefbeelden, referenties en ontwikkelingspotenties te bepalen.

Verder bestaat er een relatie tussen de hydrobiologische districten en de watertypen (Figuur 9.3). Dit betekent dat wanneer we weten met welk watertype in welke regio we te maken hebben, we al voor een belangrijk deel kunnen voorspellen welke soorten er voor kunnen komen. Binnen een regio en watertype gaan vervolgens andere factoren een belangrijkere rol spelen, zoals waterhuishouding, inrichting, nutriëntengehalten en organische belasting, vaak factoren die onder invloed van menselijke activiteiten tot stressfactoren zijn verworden. Op dit moment komen deze typologische en regionaal-biogeografische verschillen nog onvoldoende tot uitdrukking in de KRW-referenties en -maatlatten, omdat deze voor de breed gedefinieerde KRW watertypen overal in Nederland hetzelfde zijn (van der Molen et al. 2018). 


\title{
FIGUUR 9.1
}

Hydrobiologische districten. De 36 hydrobiologische districten zijn op basis van de geomorfologie in zeven hoofdgroepen te verdelen: Reliëfrijke districten 17, 18, 21, 22, 24, 34, 35, 36; Hoger gelegen zandgronden 5, 14, 16, 20, 29, 30, 31, 33, 27; Hoogveengebieden 6, 32; Lager gelegen zoete zand- en kleigebieden 4, 7, 8, 11, 12, 13, 15, 19, 23; Brakke klei- en veengebieden 1, 2, 3,

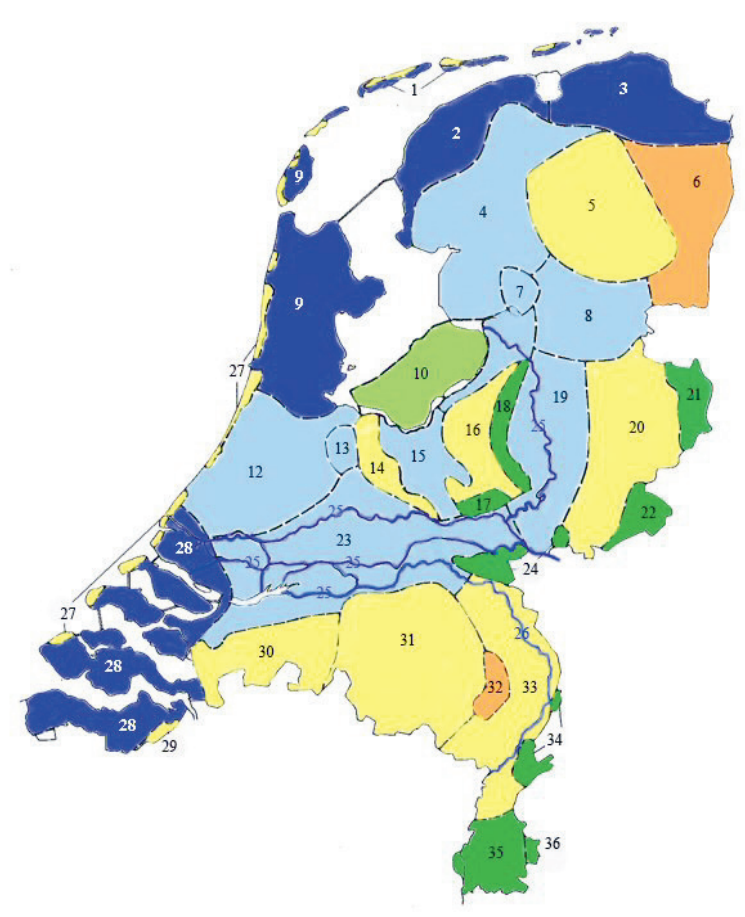

\begin{abstract}
LEGENDA NUMMERING
1 Waddeneilanden. 2. Noordwest-Friesland. 3. Noord-Groningen. 4. Zuidoost-Friesland en Noordoostpolder. 5. Drents plateau. 6. Zuidoost-Groningen en Drenthe. 7. Noordwest-Qverijssel. 8. Dal van de Reest en Overijsselse Vecht. 9. Noord-Holland (incl. Texel) m.u.v. de duinen. 10. Zuidelijke IJsselmeerpolders. 11. IJsseldelta en zuidoostelijke IJsselmeerkust. 12. Zuid-Holland m.u.v. het duingebied en het rivierenlandschap. 13. Utrechtse plassengebied. 14. Utrechtse heuvelrug en het Gooi. 15. Gelderse Vallei. 16. Veluwe. 17. Zuidelijke Veluwerand. 18. Oostelijke Veluwerand. 19. Dal van IJssel. 20. Oostelijk stuwwallenlandschap. 21. 0ostelijk Twente. 22. Achterhoek. 23. Omgeving grote rivieren m.u.v. de omgeving van Limburgse Maas (district 33) en IJssel (district 19). 24. Rijk van Nijmegen en Montferland. 25. Grote rivieren m.u.v. de Maas bovenstrooms van Grave. 26. Maas bovenstrooms van Grave. 27. Duinen. 28. Zeeland en Zuidhollandse eilanden m.u.v. het duingebied en het zuiden van Zeeuws-Vlaanderen (districten 27 en 29). 29. Zuidelijke delen van Zeeuws-Vlaanderen. 30. West-Brabant. 31. 0ost-Brabant. 32.Peel 33. Limburg m.u.v. het zuiden (district 35 en 36) en het gebied ten oosten van Roermond (district 34). 34. Midden-Limburg. 35. Zuid-Limburg m.u.v. het noordoostelijke deel (district 36). 36 . Noordoostelijk Zuid-Limburg.
\end{abstract}

\section{FIGUUR 9.2}

Indelingen van oppervlaktewateren naar ecologische sleutelfactoren waarbij de indelingen naar voedselrijkdom, zuurgraad en droogval ieder ten dele (middelgrote en grote stromende en stilstaande wateren zullen soms of niet droogvallen) of geheel aan de bovenste groepering van de drie stromende en drie stilstaande watertypen (naar van der Hoek et al. 1994).

\begin{tabular}{l|l|} 
Ecologische sleutelfactor & chloride \\
stroming & \\
dimensies (diepte) & \\
& \\
voedselrijkdom & \\
zuurgraad & \\
droogval & \\
\end{tabular}

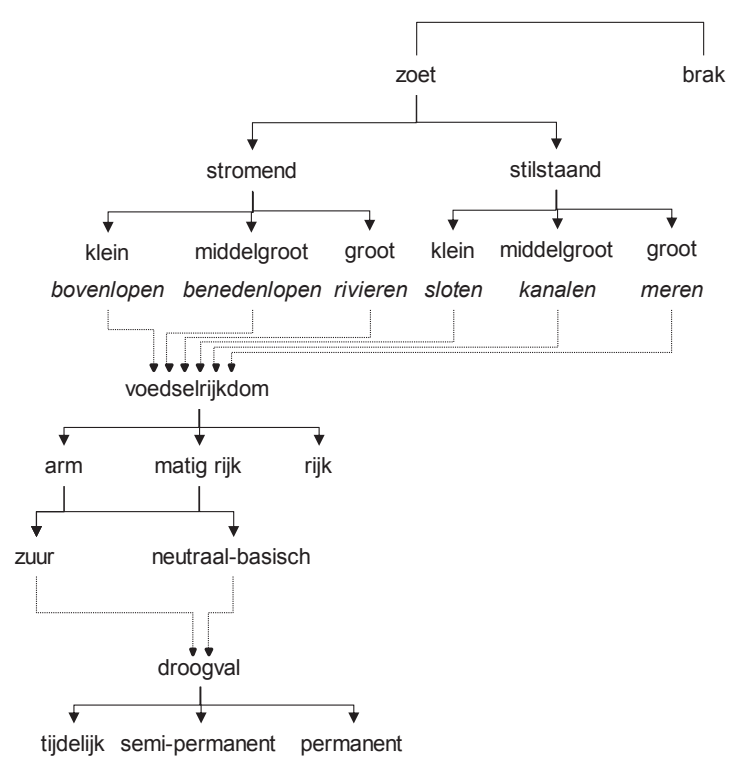




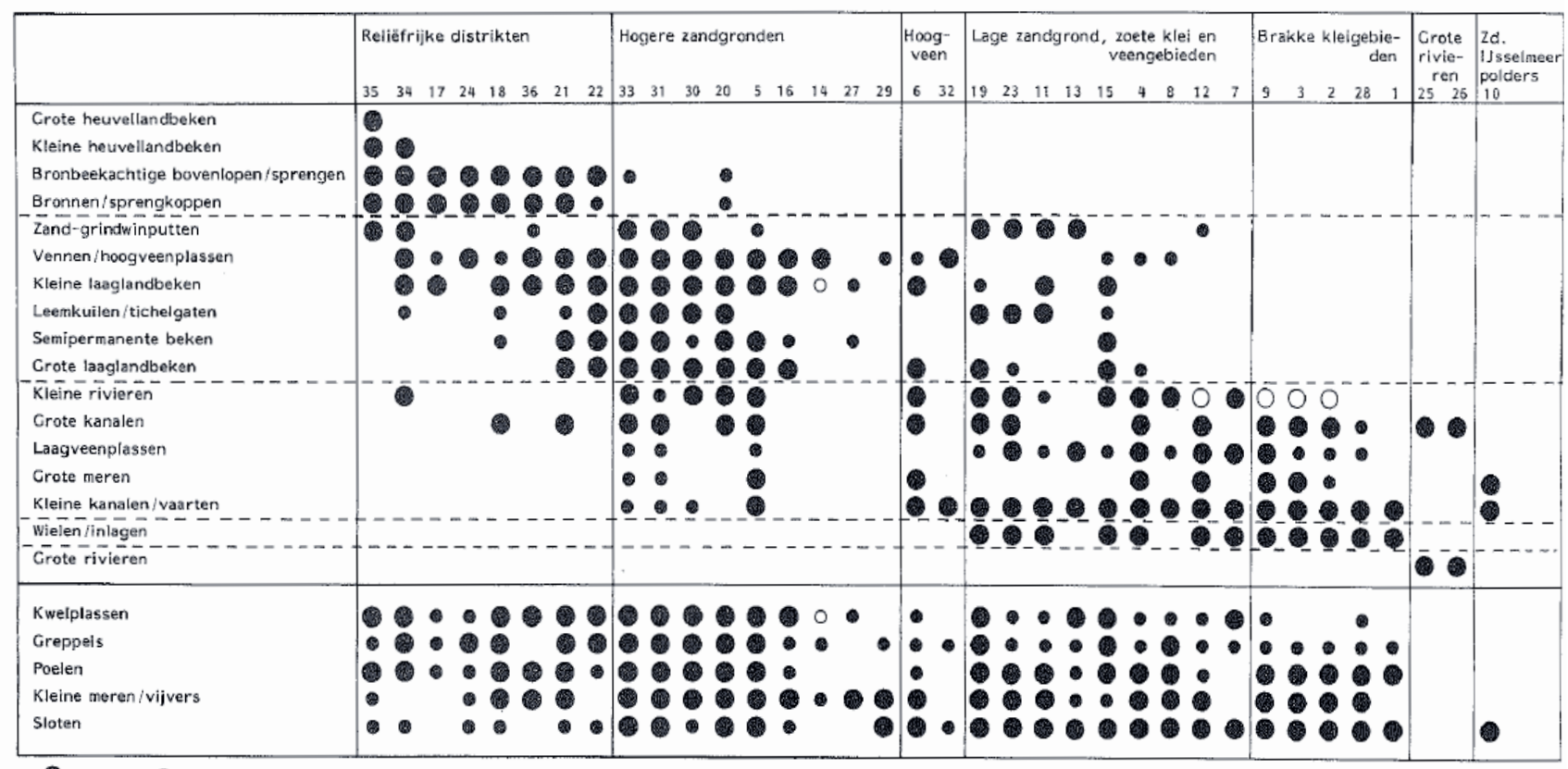

Aanwezig OVroeger aanwezig Aanwezig, maar zeer weinig OVroeger aanwezig, maar zeer weinig

\subsection{Het natuurlijk "macro" functioneren}

De randvoorwaarden die de ecosysteemtoestand en het functioneren waarin een waterlichaam zich onder natuurlijke omstandigheden zou bevinden worden bepaald door de systeemvoorwaarden in het macrosysteem. Het gedeelte van het macrosysteem waarbinnen het waterbeheer zich afspeelt, maar waar het waterbeheer nauwelijks invloed op heeft, kan worden omschreven als de "externe conditione $\neg$ rende ruimte”. In het 5-S-model is deze externe ruimte ondergebracht in de systeemvoorwaarden. De hoofdfactoren in het macrosysteem zijn klimaat, geologie, geohydrologie, geomorfologie en geochemie.

\subsubsection{Klimaat}

De belangrijkste door het klimaat bepaalde biologische factor is temperatuur. De hoeveelheid zoninstraling bepaalt de hoeveelheid energie die in een systeem wordt opgenomen, met als belangrijkste resultante de temperatuurhuishouding van het water. De temperatuur is bepalend voor de activiteit van alle levende organismen, bijvoorbeeld voor de afbraak van organisch materiaal. In Nederland volgt de gemiddelde watertemperatuur vertraagd en afgezwakt de fluctuaties in de luchttemperatuur. Door de watermassa worden de extremen in de luchttemperatuur gebufferd. In stromend water is deze buffering sterker dan in stilstaand water en in beschaduwde situaties is deze in het zomerhalfjaar nog sterker. Stromend water vriest 's winters onder de Nederlandse klimatologische omstandigheden zelden volledig dicht. Doorgaans zijn de meer beschaduwde bovenstroomse trajecten kouder en minder aan schommelingen onderhevig dan de minder beschaduwde benedenstroomse trajecten. Naast beschaduwing heeft ook de aanvoer van grondwater invloed op de watertemperatuur. Een groter aandeel kwelwater, dat gemiddeld een meer constante temperatuur heeft, dempt de temperatuurschommelingen. Dimensies spelen ook een rol; kleinere waterlichamen/-massa's volgen de luchttemperatuur meer direct dan grote. Tussen directe instraling van zonlicht en de aanwezigheid van macrofyten en algen is dikwijls een oorzakelijk verband aan te wijzen. Het lichtklimaat is daardoor mede bepalend voor de micro-habitatstructuur in oppervlaktewateren en oefent zo ook indirect invloed uit op de samenstelling van de levensgemeenschap.

Nederland heeft een gematigd zeeklimaat met een jaarlijks neerslagoverschot. Het neerslagoverschot varieert van 150 tot $300 \mathrm{~mm}$ met een gemiddelde van circa $225 \mathrm{~mm} / \mathrm{j}$ aar. Echter zijn hier in de recente periode behoorlijke wisselingen in her- 
kenbaar door klimaatverandering. Geografisch zijn de onderlinge verschillen vrij gering. De periode waarin neerslagoverschot optreedt loopt van september tot april. Van april tot september is er een neerslagtekort. De hoeveelheid jaarlijkse neerslag varieert van circa 700 tot $800 \mathrm{~mm}$ met een gemiddelde van circa $750 \mathrm{~mm}$. De geografische verschillen zijn vooral van belang wanneer naar dagsommen van de neerslag wordt gekeken. De jaarlijkse verschillen hierin kunnen aanzienlijk zijn.

Neerslag is van nature erg arm aan opgeloste stoffen en wordt atmotroof genoemd. Neerslag is van nature zwak zuur tot neutraal (5.5-7.0), afhankelijk van locatie en seizoen. Oppervlaktewateren die veel direct regenwater ontvangen zijn over het algemeen iets zuurder, mede als gevolg van de in de depositie aanwezige verzurende stoffen.

\subsubsection{Geohydrologie}

Het neerslagoverschot in Nederland wordt via het grond- en oppervlaktewater naar zee afgevoerd. Afstroming over het grondoppervlak is qua volume marginaal, zodat vrijwel al het afgevoerde water een kortere of langere tijd deel uitmaakt van het grondwater. Drukverschillen in het grondwater, die samenhangen met het reliëf, veroorzaken stroming van het grondwater. De doorlatendheid van de sedimenten waaruit de ondergrond bestaat bepaalt daarbij de weerstand die het stromende grondwater ondervindt. Een belangrijke factor hierbij is de korrelgrootteverdeling.

De ondergrond van Nederland bestaat uit een halfcirkelvormig grondwaterbekken dat open is in noordelijke en westelijke richting. Langs de zuid- en oostgrens van het land liggen slecht doorlatende Tertiaire afzettingen van mariene oorsprong dichtbij of aan het oppervlak. Alleen in Zuid-Limburg spelen ook Pre-Tertiaire afzettingen (voornamelijk kalksteen) een rol. De Tertiaire afzettingen vormen, in het oostelijk deel van Nederland, de slecht doorlatende basis van het grondwaterbekken. In noordwestelijke richting komen deze Tertiaire afzettingen steeds dieper te liggen en worden ze bedekt door een laag Oud-Pleistocene mariene afzettingen met talrijke ondoorlatende kleilagen. In het noorden en westen van Nederland zijn deze kleilagen de basis van het grondwaterbekken.

De slecht doorlatende Tertiaire en Oud-Pleistocene afzettingen zijn bedekt met een tot $250 \mathrm{~m}$ dik pakket goed doorlatende fluviatiele zanden van Pliocene en Pleistocene ouderdom (de Plio-Pleistocene aquifer of watervoerende laag). De doorlatendheid van deze aquifer neemt globaal genomen toe in noordwestelijke richting. Deze Plio-Pleistocene afzettingen worden in de meeste gebieden doorsneden door een klein aantal kleirijke lagen (aquitard of slecht doorlatende laag). In Zuid-Nederland zijn dit de formaties van Kedichem en Tegelen, in het noorden zijn het glaciale kleiafzettingen (Eemien-klei en Formatie van Peelo). In hoog Nederland wordt de Plio-Pleistocene aquifer grotendeels afgedekt door Pleistocene dekzandlagen tot $20 \mathrm{~m}$ dik. In deze fijne zandafzettingen komen plaatselijk leem- en veenformaties voor. In westelijk Noord-Brabant en Drenthe is de situatie anders. Hier wordt de Plio-Pleistocene aquifer afgedekt door respectievelijk leem en (glaciale) keileem. In laag Nederland wordt de Plio-Pleistocene aquifer afgedekt door slecht doorlatende Holocene klei- en veenafzettingen.

Grote delen van Nederland worden gekenmerkt door een hoge grondwaterstand. Dit betekent dat de gemiddelde stijghoogte (de hoogte, vaak uitgedrukt in $\mathrm{m}$ boven N.A.P., tot waar grondwater opstijgt in een buis die in open verbinding staat met atmosfeer en aquifer) meestal dicht bij het maaiveld ligt. De hoogste delen van het land (Zuid-Limburg, de stuwwallen en de duinen) vormen hierop een uitzondering: hier ligt de grondwaterspiegel soms tientallen meters onder het maaiveld. Aangezien de opeenvolgende aardlagen in de Nederlandse ondergrond wegduiken in noordwestelijke richting, zou dus verwacht kunnen worden dat de grondwaterstroming in de Plio-Pleistocene aquifer overwegend in noordwestelijke richting is (d.w.z. in de richting waarin de stijghoogte ten opzichte van N.A.P.) globaal afneemt). Het blijkt echter dat de lokale topografie van grotere invloed is op de grondwaterstroming. Het grootste deel van het neerslagoverschot in de aquifer wordt namelijk afgevoerd in een richting loodrecht op de globale stijghoogtegradiënt, naar sloten, beken en rivieren.

Een interessant geohydrologisch verschil tussen hoog en laag Nederland is dat rivieren en beken in het hoge Pleistocene deel van het land doorgaans drainerend werken, terwijl uit de grote watergangen van het meer kunstmatige drainagenetwerk in laag Nederland doorgaans water inzijgt naar de ondergrond (o.a. Meinardi 1980, Dufour 1998, Paulissen \& Verdonschot 2007). 
De hogere delen van Nederland zijn inzijggebieden waar de grondwatervoorraad wordt aangevuld met infiltrerend regenwater. De grondwaterspiegel lag en ligt hier vaak tot tientallen meters diep onder het maaiveld (afhankelijk van de topografie en de aard van het geologisch substraat). De hoogst gelegen delen van Nederland hebben daarom veelal geen uitgebreid natuurlijk ontwateringsysteem aan het oppervlak; ze zijn arm aan beken en rivieren. De meeste hoog gelegen natuurlijke waterlopen ondervinden in deze situatie inzijging vanuit de bedding, die daardoor in sommige gevallen in droge tijden geen water voeren (bijvoorbeeld droogdalen in Zuid-Limburg).

Op ruimtelijk niveau kunnen drie grondwaterstromingspatronen worden onderscheiden (Dufour 1998): lokale, subregionale (of intermediaire) en regionale stroming. Lokale grondwaterstromingen verbinden inzijggebieden met (zeer) dichtbij gelegen kwelgebieden. De verblijftijd van het lokale grondwater, d.w.z. de tijd tussen inzijging en kwel, is in de ordegrootte van dagen tot jaren. Een voorbeeld van een lokaal systeem is het Springendal in Twente, waar grondwaterstroming optreedt van een es (hoog gelegen inzijggebied) naar een brontak in een lokale terreindepressie.

Subregionale grondwaterstromingen bevinden zich per definitie onder lokale stromingspatronen. Typisch voor deze stromingen is dat grondwater van één infiltratiegebied over een periode van (doorgaans) eeuwen naar meerdere kwelzones stroomt.

Regionale grondwaterstromingen liggen altijd dieper dan lokale en subregionale stromen. Deze stromingen verbinden de regionaal hoogst gelegen infiltratiegebieden met de regionaal laagst gelegen kwelgebieden. De reis van regionaal grondwater door de ondergrond kan tientallen eeuwen duren. Een voorbeeld van een gebied dat oorspronkelijk gekenmerkt werd door regionale kwel is het veengebied in Noordwest-Overijssel. Dit gebied ontving grondwater afkomstig van het Drents keileemplateau. De hydrologische situatie is hier echter veranderd van kwel naar inzijging, doordat de resterende venen omgeven werden door intensief bemalen landbouwpolders (Van Wirdum 1991). Een tweede voorbeeld van regionale kwel vinden we op de laagste Maasterrassen in Noord-Limburg, waar broekbossen in oude rivierarmen kwel ontvangen vanuit de hoog gelegen gebieden in oostelijk Noord-Brabant en tussen Maas en Rijn (Lucassen 2004). Doordat het water bij regionale grondwaterstromingen zeer veel langer in de ondergrond verblijft dan bij lokale grondwaterstromingen, is regionaal kwelwater doorgaans harder (beter gebufferd) en ijzerrijker dan lokale kwel. Doordat slecht doorlatende lagen in de Nederlandse ondergrond zelden of nooit volledig ondoorlatend zijn, neemt de waterkerende invloed van aquitards af met de verblijftijd: regionale grondwaterstromingen zijn vaak in staat aquitards te passeren. Lokale grondwaterstromingspatronen zijn vooral van belang in reliëfrijke gebieden zoals Zuid-Limburg en Noordoost-Twente, terwijl op landelijke schaal vooral (sub)regionale grondwatersystemen een grote rol spelen (Dufour 1998).

De laagst gelegen delen van het land, d.w.z. de Holocene kustvlakte en in Zuid- en Oost-Nederland de beek-en rivierdalen, zijn de gebieden waar van oudsher regionale kwel optreedt. Door toedoen van uittredend gebufferd grondwater hebben zich tijdens het Holoceen op deze kwelplekken vaak basenrijke laagvenen gevormd, zoals in het latere Vechtplassengebied, in de laaggelegen delen van Overijssel, Friesland en Groningen grenzend aan het Drents keileemplateau en op de overgang van het Kempisch plateau naar de overstromingsvlakte van de Maas in Noord-Brabant (Lamers et al. 2001). Ook in Zuid-Limburgse beekdalen en in oude Maasarmen komen laagveenafzettingen voor (Jalink et al. 2003; Lucassen 2004). De aanwezigheid van basenrijke laagveenafzettingen in het landschap zijn een indicator voor de (vroegere) invloed van kwel, dan wel van gebufferd oppervlaktewater (bijvoorbeeld door overstromingen vanuit de grote rivieren in West-Nederland).

In veel gevallen hebben deze laagvenen zich in de loop van het Holoceen ontwikkeld tot hoogvenen. Van hoogvenen is sprake zodra er zoveel organisch materiaal is geaccumuleerd, dat de interne grondwaterstand in het veenlichaam hoger komt te liggen dan de grondwaterstand in de omliggende minerale ondergrond. In goed ontwikkelde hoogvenen zal daarom inzijging van water vanuit het veenlichaam naar de minerale aquifer optreden (Meinardi 1980). De inzijgingssnelheid is meestal echter gering, omdat de permeabiliteit van het hoogveenlichaam zeer beperkt is (Schouwenaars et al. 2002) en omdat de minerale ondergrond ter plekke doorgaans op geringe diepte slecht doorlatende lagen bevat. Ook in depressies in dekzandgebieden hebben zich hoogvenen gevormd gedurende het Holoceen, vooral op plekken met een gebrekkige drainage, bijvoorbeeld door de aanwezigheid van ondiepe keileemlagen. In de loop van de tijd zijn deze venen vaak sterk uitgebreid en zijn ze de omringende minerale gronden gaan bedekken (Meinardi 1980). 
Tot in de Middeleeuwen was een aanzienlijk deel van Nederland bedekt met hoogvenen (Zagwijn 1986; Pons 1992). Talrijke plaats- en terreinnamen verwijzen hiernaar (Schouwenaars et al. 2002). Op de Hollandse kustvlakte is een deel van het hoogveen al in prehistorische tijden door toedoen van erosie door de binnendringende zee verdwenen. Van de overgebleven hoogvenen in dit gebied lag het maaiveld in de eerste eeuwen van onze jaartelling enkele meters boven zeeniveau (Kwaad 1961; Kwaad et al. 1965). Op andere plekken in laag Nederland werd het veen sinds de 12e eeuw oppervlakkig gedraineerd ten behoeve van kleinschalige akkerbouw (Borger 1992). Aanhoudende drainage sinds het ontstaan van de eerste polders heeft geleid tot sterke inklinking van het veen. Opgeteld bij een absolute zeespiegelstijging heeft dit ertoe geleid dat het maaiveld in veel West- en Noord-Nederlandse polders beneden zeeniveau is komen te liggen (Kwaad 1961; Kwaad et al. 1965). Ook in hoog Nederland zijn de grote hoogveengebieden, vooral in Noord-Brabant en Drenthe, stuk voor stuk verdwenen door ontginning (Borger 1992).

\subsubsection{Geomorfologie}

De geomorfologie omvat de geologie, de bodem en het reliëf. De relaties tussen drie componenten zijn wederkerig maar over het algemeen is het reliëf dominant. Het reliëf is door natuurlijke processen van water-, wind-, ijs- en zeewerking ontstaan en het is goed te herkennen als vormen in het landschap, zoals beek- en rivierdalen, dekzandruggen, stuwwallen en stuifduinen. Op grond van de ontstaanswijze kunnen drie belangrijke geomorfologische gebieden in Nederland worden onderscheiden:

- Pre-pleistocene gebieden; gebieden ontstaan door tektonische processen (Zuid-Limburg, oostelijk Twente en Achterhoek).

- Pleistocene gebieden; gebieden ontstaan door klimatologische processen m.n. water- en winderosie (hogere zandgronden).

- Holocene gebieden; gebieden ontstaan door fluviatiele en mariene processen (overige gebieden in laag Nederland).

Het reliëf is verder bepalend voor het grondwater, de bodem en de begroeiing. Meer in detail worden in het landschap 12 vormgroepen onderscheiden die ook voor de ligging en het functioneren van oppervlaktewateren van belang zijn: 1.) wanden; 2.) glooiingen; 3.) terrasvormen; 4.) plateaus; 5.) plateau-achtige vormen; 6.) geïsoleerde hoge heuvels en heuvelruggen; 7.) hoge heuvels en heuvelruggen met bijbehorende vlakten en laagten; 8.) geïsoleerde lage heuvels, ruggen en welvingen; 9.) lage heuvels, 10.) ruggen en welvingen met bijbehorende vlakten en laagten; 11.$)$ vlakten; 12 .) niet-dalvormige laagten en dalvormige laagten.

Klimaat, bodem, reliëf en (geo)hydrologie leiden samen tot landschapsvormende processen die onder natuurlijke omstandigheden in belangrijke mate bepalend zijn voor de aanwezige levensgemeenschappen. Op basis van deze combinatie zijn fysisch-geografische landschappen beschreven, die sturend zijn voor de aanwezige aquatische watertypen (Figuur 9.4). 
FIGUUR 9.4

Fysisch-geografische landschappen in Nederland (Atlas van Nederland, Deel 16 Landschap).

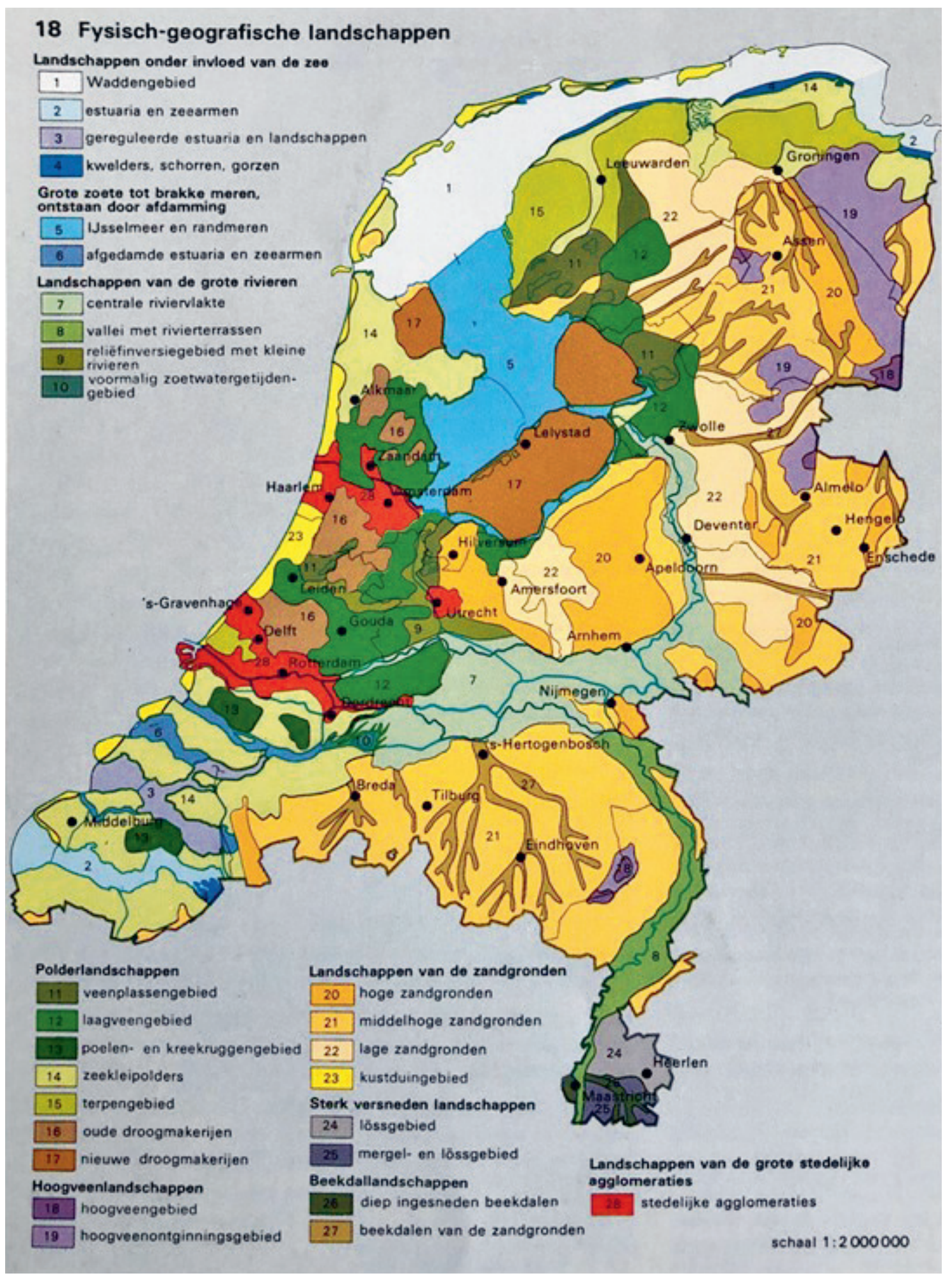


De samenstelling van het grondwater in Nederland is in ruimte en tijd zeer variabel en wordt beïnvloed door zowel de eigenschappen van het geologische substraat als de ouderdom (ofwel de ondergronds afgelegde route) van het geïnfiltreerde water. De samenstelling van in de bodem infiltrerend neerslagwater verandert door biologische processen in de toplaag van de bodem en de chemische uitwisselingsprocessen met bodemdeeltjes c.q. het gesteente. Uitgangspunt van het ontwikkelingsproces van grondwater is het voedende neerslag- of oppervlaktewater. Door alle latere processen die betrokken zijn bij de grondwatervorming, wijkt de uiteindelijke samenstelling doorgaans sterk af van de samenstelling van dit infiltrerende water. Chemische processen in de diepere ondergrond, waar het grondwater doorgaans tientallen tot honderden jaren verblijft, drukken hun stempel op de samenstelling. Echter de kenmerken van het voedingsgebied, zoals topografie, bodemtype en begroeiing, zijn belangrijker dan het verblijf (duur, stromingspatroon) van het water in de diepere ondergrond (Meinardi 1980). De globale veranderingen die optreden tijdens de tocht door de ondergrond van infiltrerend regenwater tot aan het moment van uittreden zijn bepalend voor de geochemische samenstelling van het grondwater op het moment dat als kwel in het oppervlaktewater terecht komt (Figuur 9.5).

\section{FIGUUR 9.5}

Schematisch overzicht van een regionale grondwaterstroom van inzijggebied naar kwelzone, de belangrijkste chemische veranderingen die het grondwater hierbij ondergaat en de verantwoordelijke processen. De getal-lettercodes verwijzen naar de biogeochemische processen in Tabel 9.1 (Paulissen \& Verdonschot 2007).

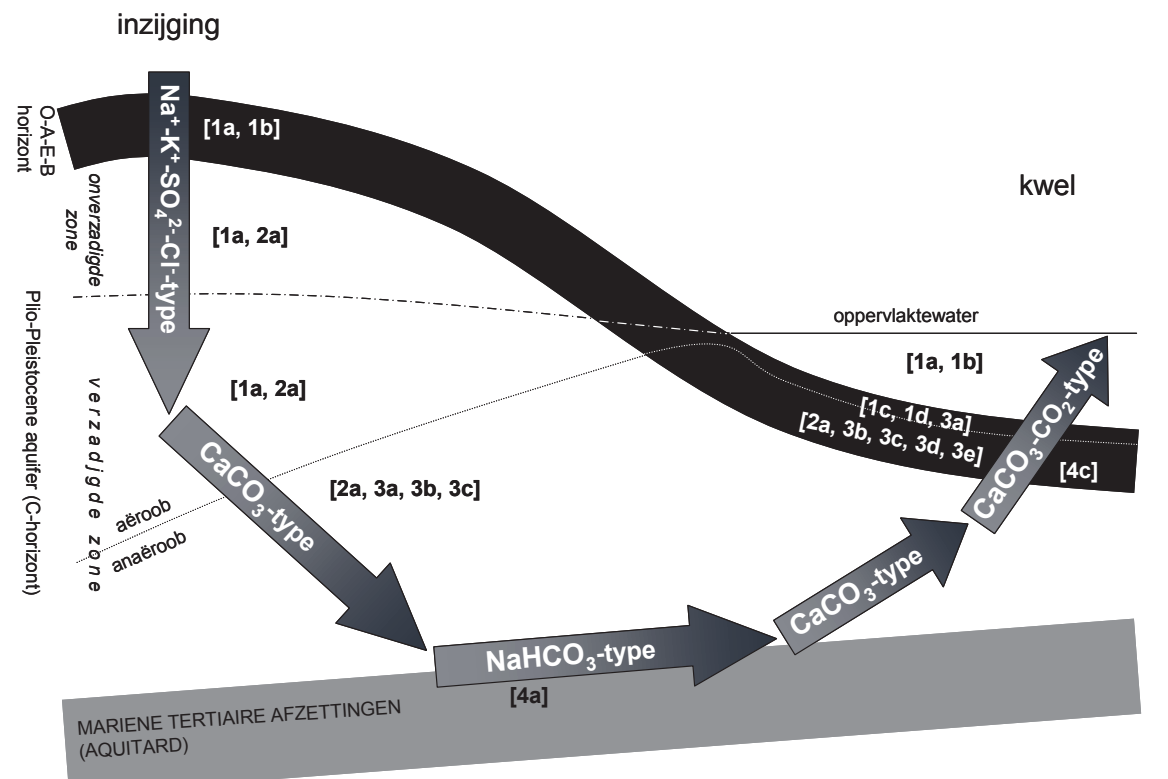


TABEL 9.1

Reactievergelijkingen van belangrijke processen die de samenstelling van het Nederlandse grondwater beïvloeden (ads $=($ aan bodemdeeltjes) geadsorbeerde fase)(naar Paulissen \& Verdonschot 2007).

\begin{tabular}{|c|c|}
\hline $\begin{array}{l}\text { Proces } \quad \text { Belangrijkste plaatsen waar proces plaatsvindt } \\
\text { [1] Reacties in oxidatieve (aërobe) milieus (zuurproducerend) }\end{array}$ & Consequenties voor samenstelling grondwater \\
\hline 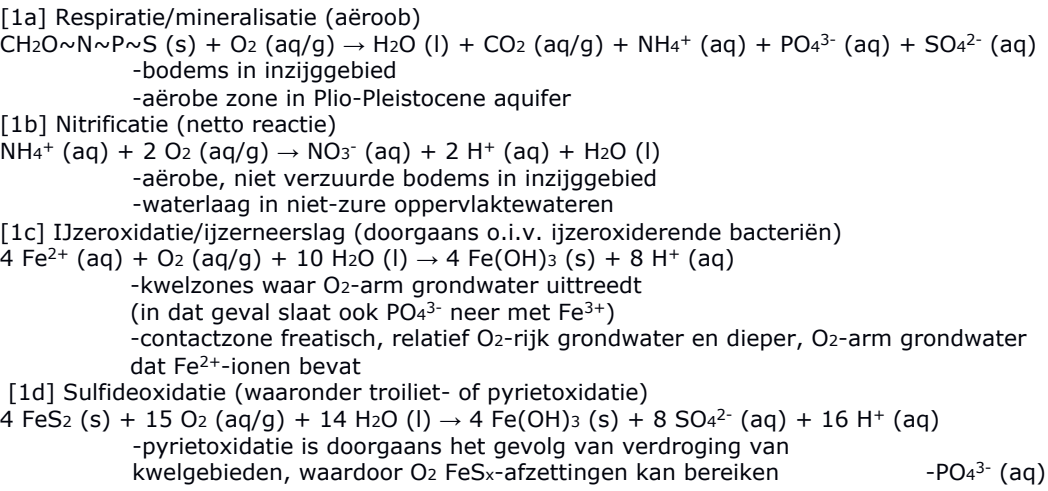 & $\begin{array}{l}-\mathrm{O}_{2} \text { daalt } \\
-\mathrm{CO}_{2} \text { stijgt } \\
-\mathrm{pH} \text { daalt door } \mathrm{CO}_{2} \text { productie } \\
-\mathrm{pH} \text { daalt door vrijgekomen } \mathrm{H}^{+} \\
-\mathrm{O}_{2} \text { daalt }\end{array}$ \\
\hline $\begin{array}{l}\text { [2] Verweringsreacties (zuurconsumerend) } \\
{[2 \mathrm{a}] \mathrm{Oplossing} \mathrm{CaCO}_{3} \text { (calciet) en } \mathrm{CaMg}\left(\mathrm{CO}_{3}\right)_{2} \text { (dolomiet) }} \\
\mathrm{CaCO}_{3}(\mathrm{~s})+\mathrm{H}_{2} \mathrm{O}(\mathrm{I})+\mathrm{CO}_{2}(\mathrm{aq} / \mathrm{g})<=>\mathrm{Ca}^{2+}(\mathrm{aq})+2 \mathrm{HCO}_{3}^{-}(\mathrm{aq}) \\
\mathrm{CaMg}\left(\mathrm{CO}_{3}\right)_{2}+2 \mathrm{H} \mathrm{H}_{2} \mathrm{O}(\mathrm{I})+2 \mathrm{CO}_{2}(\mathrm{aq} / \mathrm{g})<=>\mathrm{Ca}^{2+}(\mathrm{aq})+\mathrm{Mg}^{2+}(\mathrm{aq})+4 \mathrm{HCO}_{3}^{-}(\mathrm{aq}) \\
\quad \text {-bodem in inzijggebied } \\
\quad \text {-Plio-Pleistocene aquifer } \\
\quad \text {-bodem in kwelgebied }\end{array}$ & $\begin{array}{l}-\mathrm{CO}_{2} \text { daalt } \\
\text { or vrijkomen } \mathrm{Ca}^{2+} \text { en/of } \mathrm{Mg}^{2+} \\
\text {-pH stijgt door } \mathrm{CO}_{2} \text { consumptie }\end{array}$ \\
\hline 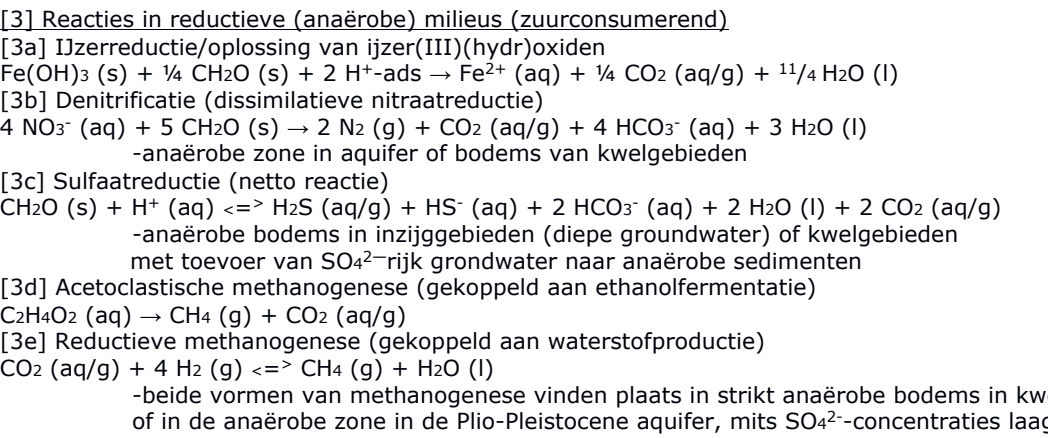 & $\begin{array}{l}\text {-pH stijgt door } \mathrm{HCO}_{3}^{-} \text {productie } \\
\text {-het grondwater wordt stikstofarmer } \\
\text {-pH stijgt door } \mathrm{H}^{+} \text {consumptie/ } \mathrm{HCO}_{3}^{-} 2 \mathrm{SO}_{4}^{2-}(\mathrm{aq})+4 \\
\text { productie }\end{array}$ \\
\hline 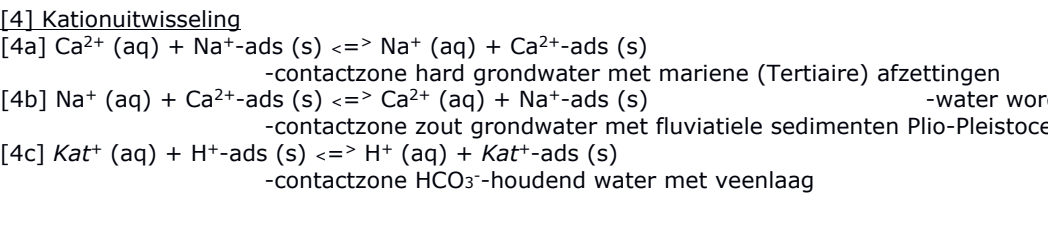 & 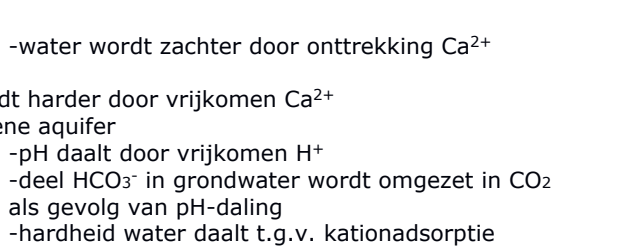 \\
\hline
\end{tabular}




\subsection{Menselijke activiteiten}

Menselijke activiteiten (drivers en pressures) kunnen leiden tot veranderingen in milieufactoren. Bij verstoring is er sprake van negatieve invloed en bij herstel is er sprake van positieve invloed op de ecosysteemstructuur en het ecosysteem functioneren. Menselijke activiteiten met negatieve effecten worden vaak onder de noemer van stressfactoren gerangschikt. Stressfactoren oefenen stress uit op het ecosysteem. Zoals al eerder aangegeven betreffen stressoren meestal niet individuele factoren maar factorcomplexen. Bij agrarisch landgebruik bijvoorbeeld kunnen meerdere stressfactoren tegelijk tot uiting komen, bijvoorbeeld een combinatie van eutrofiëring, kanalisatie, waterkwantiteitsbeheer en toxische belasting. Elk van deze stressoren bestaat zelf weer uit individuele stressfactoren, zoals in het geval van eutrofiëring een bepaald fosfaat-, stikstof- en kaliumgehalte. Deze factoren kunnen zowel stuur- en of sleutelfactor zijn.

De hiërarchie in de DPSIRR-keten kan gebruikt worden in de aanpak van het complex van stressoren. De schaal van herstelmogelijkheden neemt sterk toe als maatregelen zich richten op de drivers van stressfactoren, m.a.w. de bron van de stress. Het betreft meestal beleidsmaatregelen met - in ruimte en tijd - grootschalige effecten.

De ecologische effecten van veranderingen (verstoring/impact) van milieufactoren, in termen van patronen en processen, zijn afhankelijk van verschillende aspecten:

- Hoeveelheid/omvang

- Duur van optreden (timing)

- Frequentie van optreden

- Moment/periode van optreden

- Snelheid van optreden

De respons van een ecosysteem op een verandering in de afvoerdynamiek hangt bijvoorbeeld af van de hoeveelheid (hoe groot is de afvoerpiek?), de duur (hoe lang houdt de piek aan?), de frequentie (hoe vaak treedt de piek op?), het moment (wanneer in het jaar treden de pieken op?) en hoe snel (hoe snel na de regenbui treedt de piek op?). De variabiliteit in deze regimes speelt een belangrijke rol in het bepalen van de geschiktheid, de ruimtelijke structuren en de temporele dynamiek binnen een habitat, biotoop of water en stuurt de ecologische processen op verschillende hiërarchische schaalniveaus binnen het ecosysteem (Poff \& Ward 1990, Townsend \& Hildrew 1994; Poff 2002). Klimaat, geologie en geomorfologie (topografie) beïnvloeden bijvoorbeeld een regime vanaf een hoger schaalniveau en vegetatie en fauna beïnvloeden het regime door terugkoppelingsmechanismen. Wijzigt er iets in het regime, bijvoorbeeld door klimaatverandering, dan kunnen (afhankelijk van de omvang, frequentie, timing, het moment en de snelheid) er veranderingen optreden in ecologische processen. Op zijn beurt leidt dit weer tot veranderingen in de structuren en functies binnen het ecosysteem, een biotoop en/of habitat.

In de praktijk is het niet nodig om steeds weer de gehele DPSIRR-keten in kaart te brengen voordat maatregelen gekozen kunnen worden. Er kan worden volstaan met een vereenvoudigde keten van veroorzakers (menselijke activiteiten die leiden tot diffuse bronnen, puntbronnen en interne bronnen), stressoren (factoren of factorcomplexen die sturend zijn voor de ecologische sleutelfactoren), responsies (effecten die door indicatieve soorten geïndiceerd worden) en maatregelen (ingrepen die bij voorkeur veroorzakers en anders de stressoren aanpakken). Belangrijke menselijke activiteiten die invloed op de Nederlandse oppervlaktewateren uitoefenen zijn:

- Klimaatverandering

- Landbouwkundig landgebruik

- Verstedelijking

- Industrie (incl. energieopwekking)

Bosbouw

Soortenmanipulatie 
Deze categorieën van activiteiten oefenen ieder, via de stressoren (stressfactoren), invloed uit op de toestand van de milieufactoren in het aquatisch ecosysteem. Zo leidt bijvoorbeeld verstedelijking tot het optreden van lozingen van overstorten en RWZI's en tot een toename van de hoeveelheid verhard oppervlak. Daardoor treedt versnelde afstroming op, die weer aanleiding kan geven voor veranderingen in de waterstelsels, bijvoorbeeld hydromorfologische wijzigingen (zoals kanalisatie). Dit kan dan weer tot een toename in het beheer en onderhoud leiden.

Belangrijk is te realiseren dat het waterbeheer steeds het watersysteem heeft proberen aan te passen aan de eisen die voortkomen uit menselijke activiteiten. Dit leidde in veel gevallen tot een afname van de waterveiligheid, waardoor nog verdergaande aanpassingen aan het watersysteem plaatsvonden.

Als voorbeelden zijn in de figuren 10.1 - 10.6 via een selectie van relaties menselijke activiteiten (klimaatverandering, agrarisch landgebruik, verstedelijking, industrie, bosbouw en soortmanipulatie) aan stressfactoren en de belangrijkste milieufactoren gekoppeld.

\section{FIGUUR 10.1}

Voorbeeld van een selectie van relaties tussen de menselijke activiteit klimaatverandering, stressfactoren en factoren in het waterecosysteem.

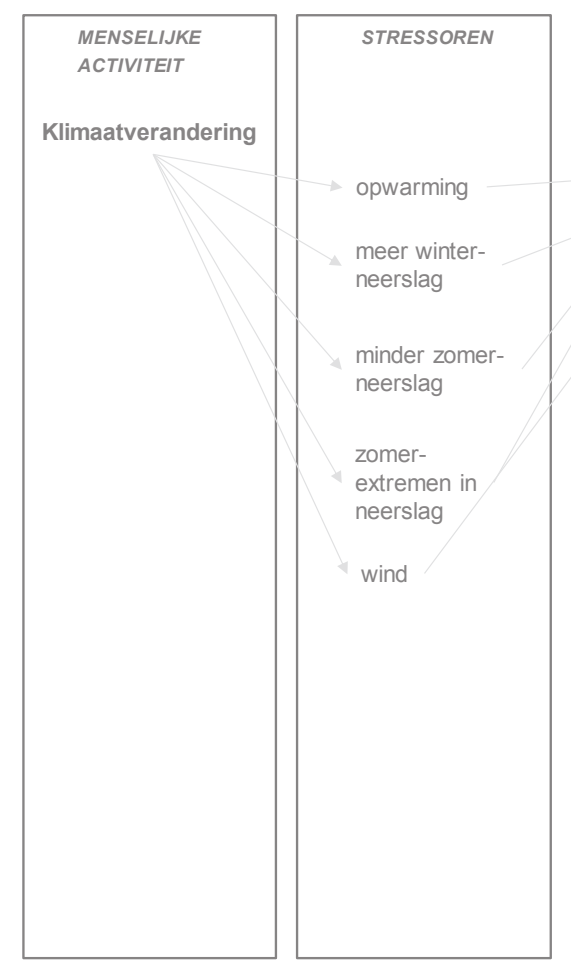

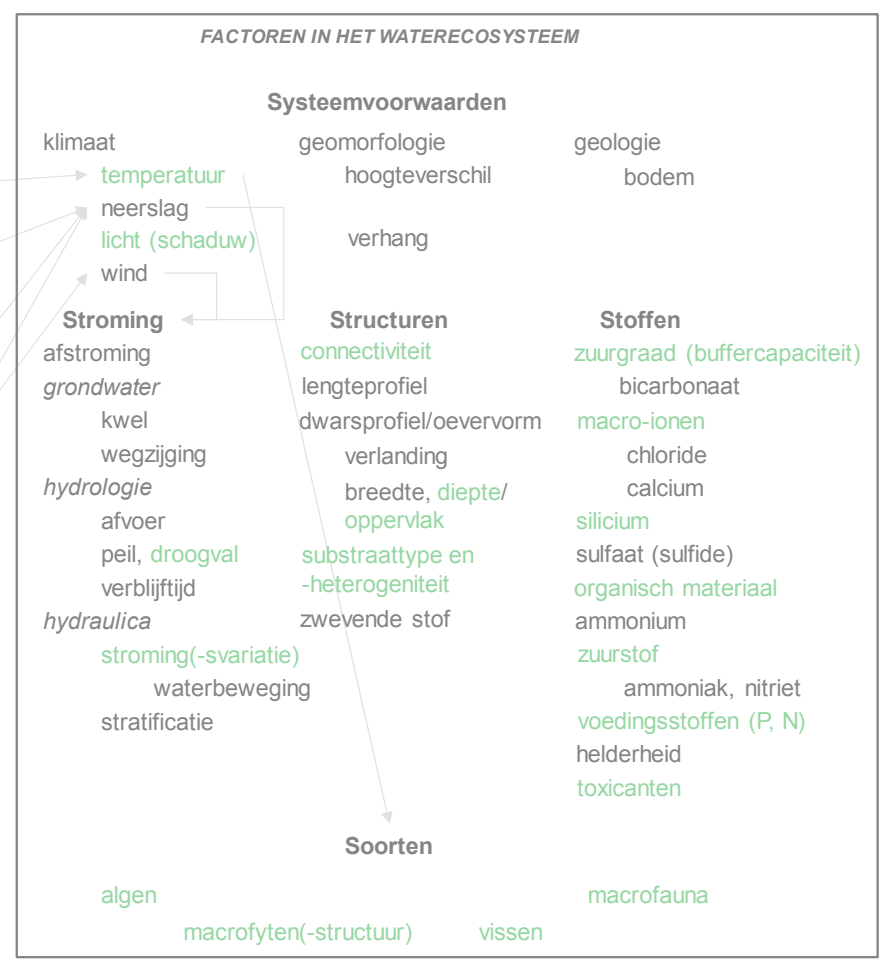


FIGUUR 10.2

Voorbeeld van een selectie van relaties tussen de menselijke activiteit agrarisch landgebruik en stressfactoren. Legenda factoren: ecologische sleutelfactor $=$ groen .

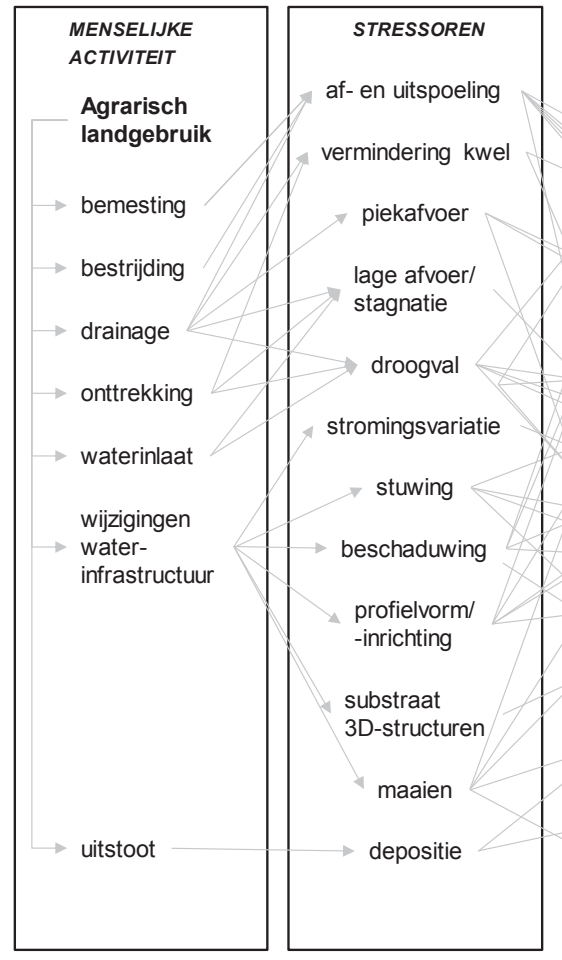

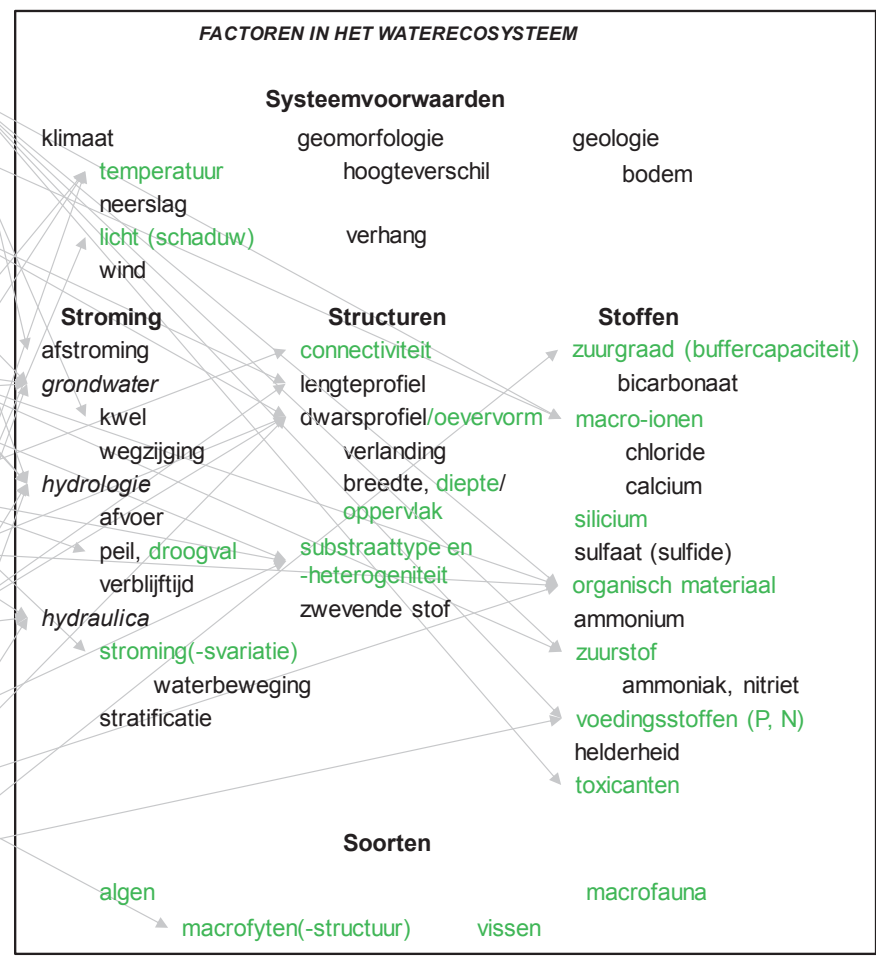

\section{FIGUUR 10.3}

Voorbeeld van een selectie van relaties tussen de menselijke activiteit verstedelijking en stressfactoren. Legenda factoren: ecologische sleutelfactor $=$ groen.

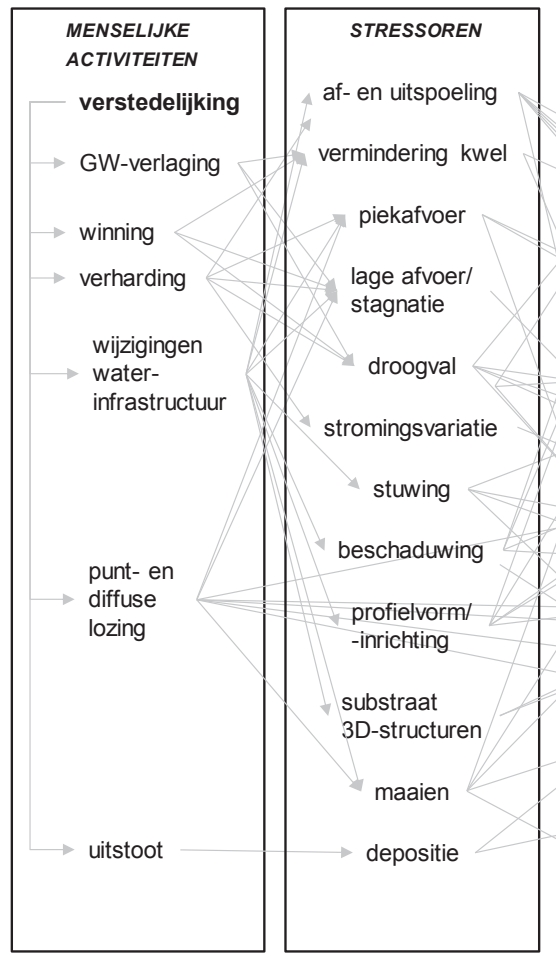

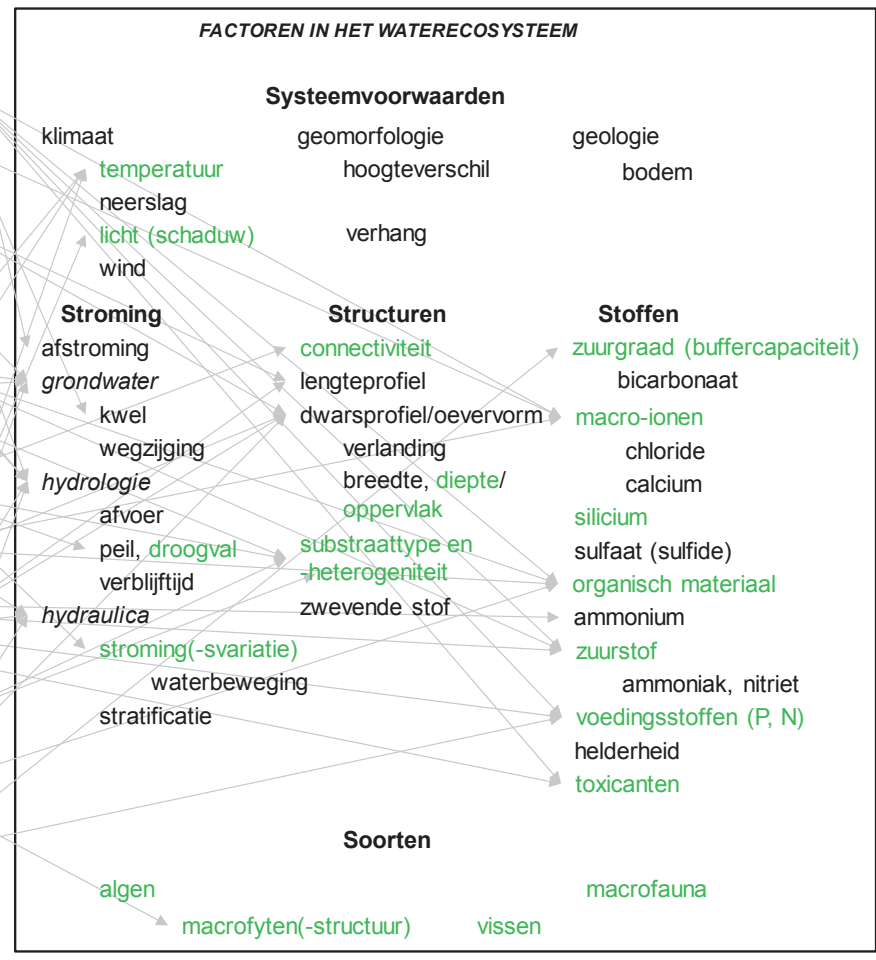




\section{FIGUUR 10.4}

Voorbeeld van een selectie van relaties tussen de menselijke activiteit industrie en energiewinning en stressfactoren. Legenda factoren: ecologische sleutelfactor = groen.

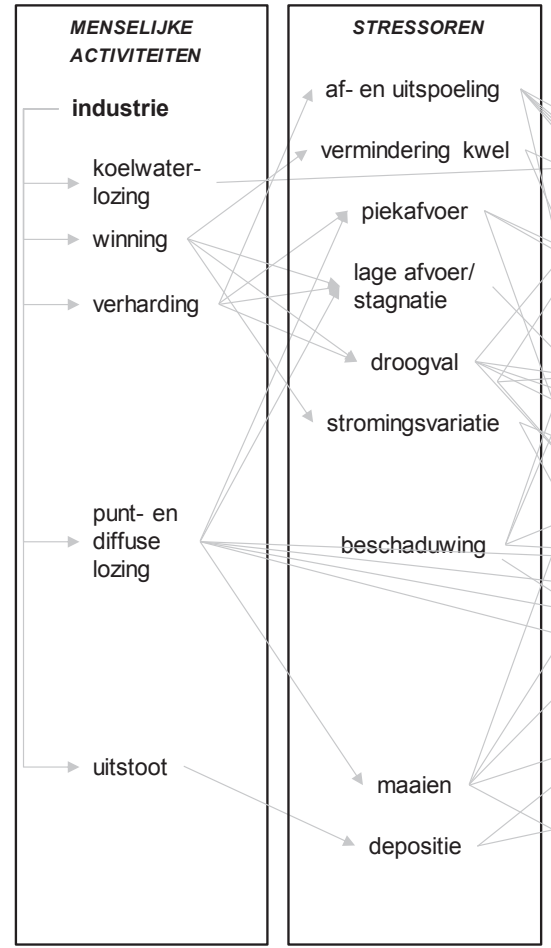

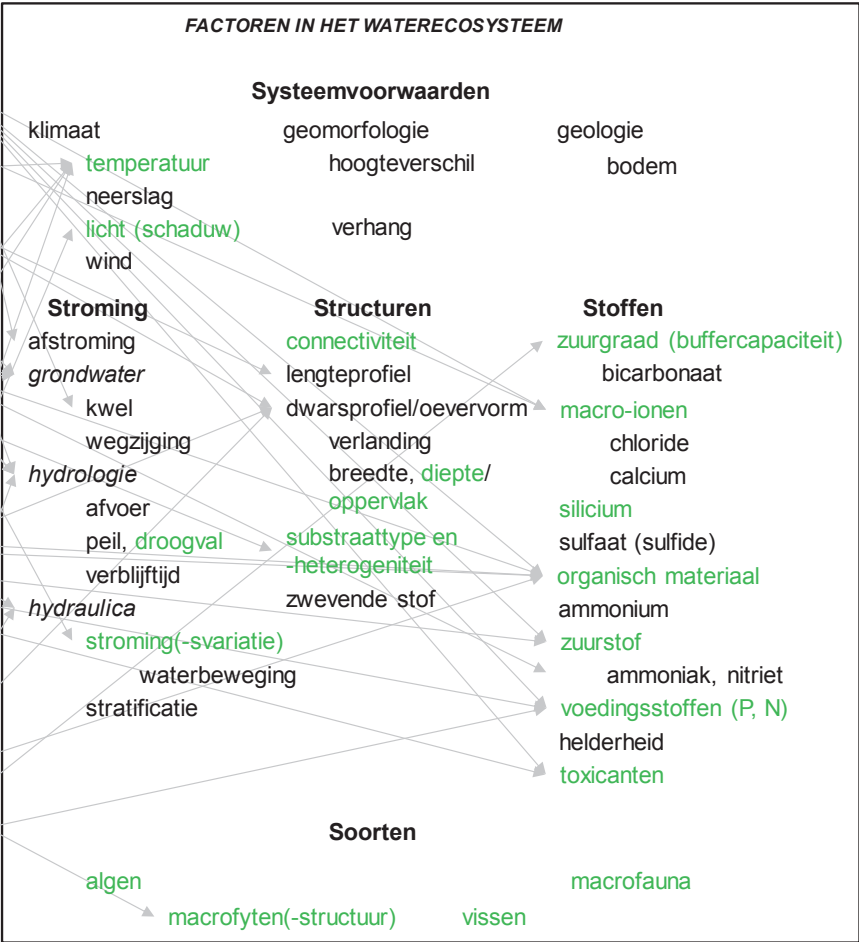

\section{FIGUUR 10.5}

Voorbeeld van een selectie van relaties tussen de menselijke activiteit productiebos en stressfactoren. Legenda factoren: ecologische sleutelfactor $=$ groen.

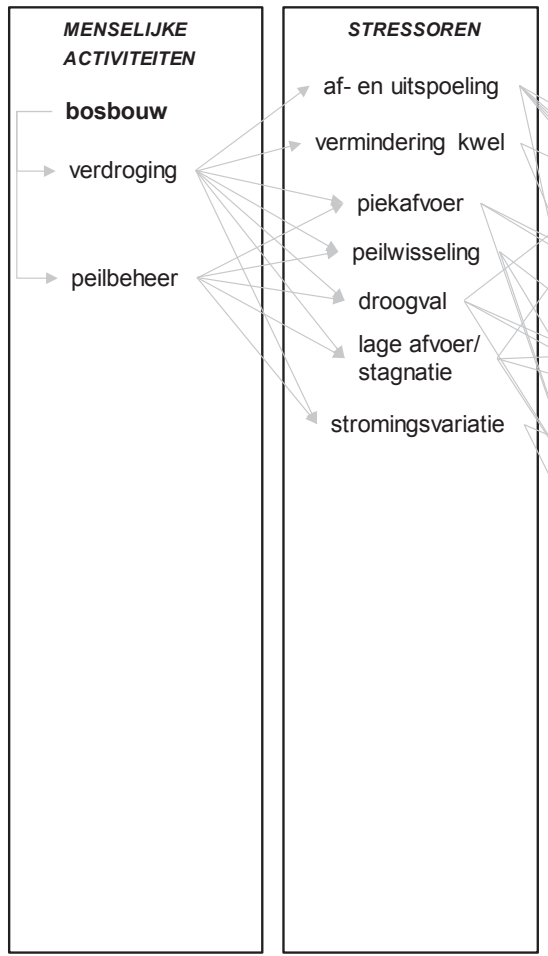

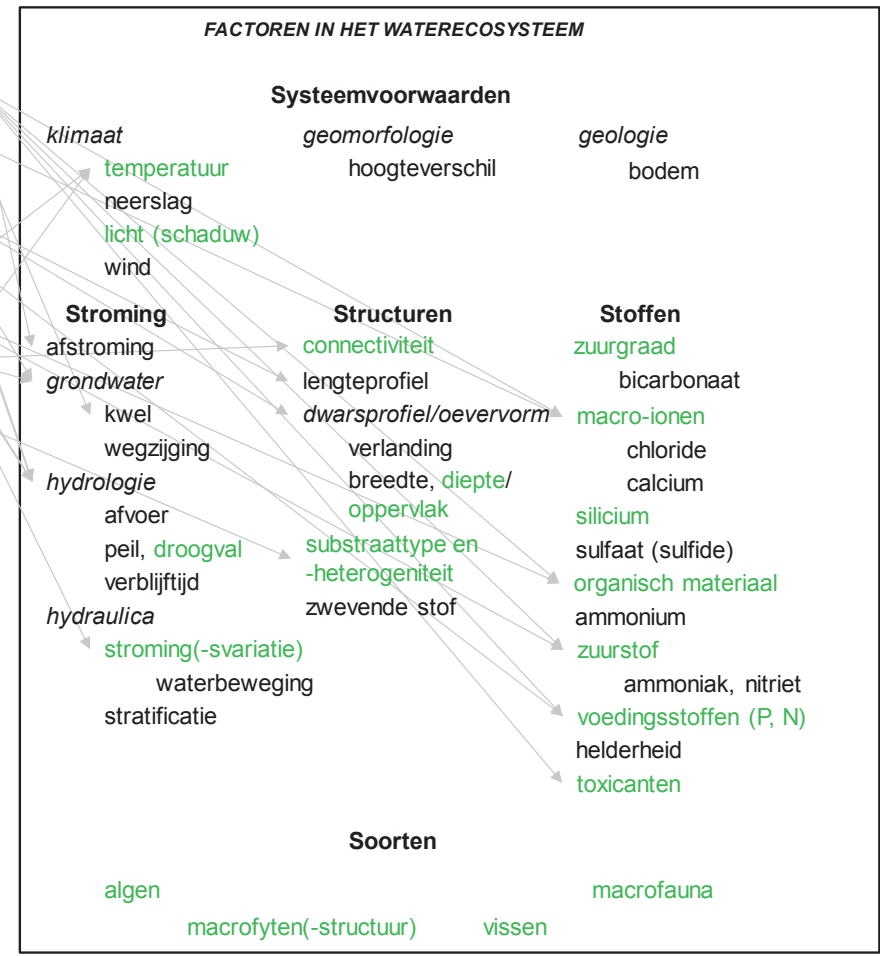




\section{FIGUUR 10.6}

Voorbeeld van een selectie van relaties tussen de menselijke activiteit soortenmanipulatie en stressfactoren. Legenda factoren: ecologische sleutelfactor $=$ groen .

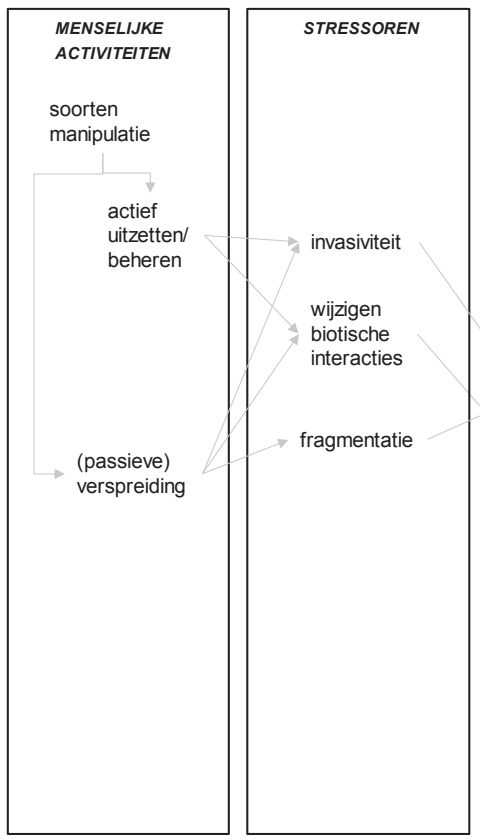

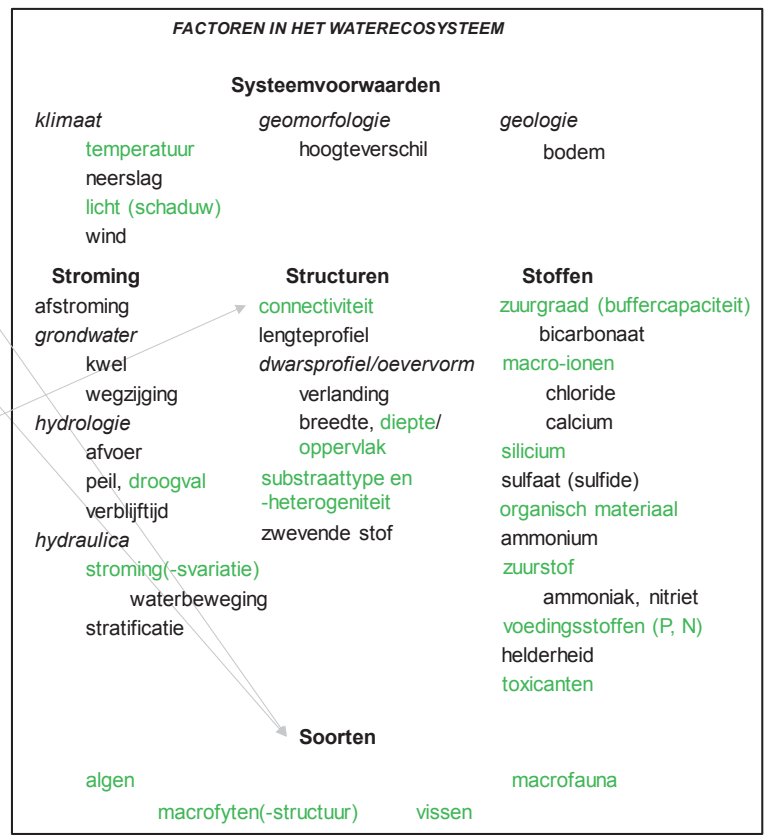

\subsection{Stressoren}

Naast sleutel- en stuurfactoren zijn er stressoren of stressfactoren. Vaak zijn deze stressfactoren gelijk aan de sleutel- of stuurfactoren, maar valt de (variatie in de) waarde van de factor buiten de range waarbinnen een soort kan voorkomen. Ook kan het een voor een organisme onbekende milieufactor zijn, bijvoorbeeld een toxicant (milieuvreemde stof). Meestal hebben menselijke activiteiten gevolgen voor meer dan één milieufactor in het ecosysteem. Landbouwkundige activiteit leidt bijvoorbeeld tot eutrofiëring (verrijking), daarbij nemen stikstof en fosfaat toe en vaak ook macro-ionen zoals kalium, natrium en chloride. Daarnaast kan er onder andere aanvoer van toxische stoffen optreden, versnelde afspoeling van regenwater van het land, toevoer van sediment en zelfs het verdwijnen van bladtoevoer door het kappen van bomen op de oever. Stressoren oefenen dus bijna altijd invloed uit op de toestand van meerdere ecologische sleutelfactoren (Tabel 10.1).

\section{TABEL 10.1}

Voorbeelden van relaties tussen stress veroorzakende processen en ecologische sleutelfactoren.

\begin{tabular}{|c|c|}
\hline Stressor & Ecologische sleutelfactor \\
\hline \multicolumn{2}{|l|}{ Diffuse bronnen } \\
\hline $\begin{array}{l}\text { Af- en uitspoeling } \\
\text { Depositie }\end{array}$ & $\begin{array}{l}\text { organisch materiaal, voedingsstoffen, ammonium, zuurstof } \\
\text { stikstof, zuurgraad }\end{array}$ \\
\hline \multicolumn{2}{|l|}{ Puntbronnen } \\
\hline RWZI, overstort, industrie & $\begin{array}{l}\text { voedingsstoffen, organisch materiaal, ammonium, zuurstof } \\
\text { gifstoffen }\end{array}$ \\
\hline Waterinlaat & macro-ionen \\
\hline Zoutlozing industrie & macro-ionen-chloride \\
\hline \multicolumn{2}{|l|}{ Systeemvoorwaarden } \\
\hline $\begin{array}{l}\text { Klimaatverandering } \\
\text { Hydrologie }\end{array}$ & licht, temperatuur, stroming, droogval, substraat \\
\hline Verstuwing & stroming, diepte, substraat, connectiviteit \\
\hline Drainage & stroming, diepte, droogval, substraat \\
\hline Verdroging & droogval, diepte, substraat \\
\hline \multicolumn{2}{|l|}{ Morfologie } \\
\hline Vormverandering & substraat, structuurheterogeniteit, macrofyten(-structuur) \\
\hline Versnippering/Fragmentatie & connectiviteit \\
\hline Verwijdering bomen & licht, temperatuur, macrofyten \\
\hline
\end{tabular}


De effecten van stressoren op de processen en daarmee op de stuur- en sleutelfactoren in het waterecosysteem verschillen per watertype (Tabel 10.2). Zo speelt stratificatie alleen een belangrijke rol in stilstaande wateren en is de afvoerdynamiek specifiek voor stromende wateren. Voor de verschillende categorieën menselijke activiteiten zijn in de tabel voorbeelden van relaties met processen en het type waterecosysteem beschreven (aangepast naar Verdonschot 2015).

\section{TABEL 10.2}

De relatie tussen de stressoren en het effect $\left(^{+}=\right.$effect optredend, $\left(_{+}^{+}=\right.$mogelijk effect) op processen in het waterecosysteem per watertype.

\begin{tabular}{|c|c|c|c|c|c|c|c|c|c|}
\hline \multirow[b]{2}{*}{ Stressor } & \multirow[b]{2}{*}{ Effecten op processen } & \multicolumn{8}{|c|}{ Watertype } \\
\hline & & 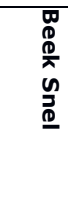 & 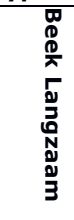 & 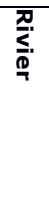 & $\frac{n}{\square}$ & 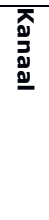 & $\begin{array}{l}3 \\
0 \\
0 \\
0 \\
0 \\
0 \\
03 \\
\frac{0}{0} \\
0\end{array}$ & $\begin{array}{l}3 \\
\frac{3}{0} \\
0 \\
7 \\
\frac{0}{0} \\
\frac{1}{0}\end{array}$ & 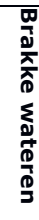 \\
\hline \multirow{6}{*}{$\begin{array}{l}\text { temperatuur } \\
\text { (opwarming) }\end{array}$} & nutriëntenhuishouding & $+\mathrm{kl}$ & $+\mathrm{kl}$ & & + & + & + & + & + \\
\hline & stratificatie & & & & & & & + & \\
\hline & zuurstofhuishouding & + & + & + & + & + & + & & \\
\hline & thermofilie & $+\mathrm{kl}$ & $+\mathrm{kl}$ & & +sch. & + & & & \\
\hline & mismatch & + & + & & + & + & + & + & + \\
\hline & fenologie & + & + & & + & + & + & + & + \\
\hline \multirow[t]{5}{*}{$>$ winterneerslag } & afvoerdynamiek & + & + & + & & & & & \\
\hline & afstroming & + & + & + & + & + & & & + \\
\hline & peildynamiek & + & + & + & + & + & + & + & + \\
\hline & waterbeweging & + & + & + & + & & + & & + \\
\hline & inundatie & + & + & + & $(+)$ & & & & \\
\hline \multirow[t]{3}{*}{ <zomerneerslag } & droogval & + & + & + & + & & $+\mathrm{kl}$. & & + \\
\hline & $\begin{array}{l}\text { zoutindringing; zoute } \\
\text { kwel }\end{array}$ & & & & + & + & + & & + \\
\hline & indamping & + & + & + & + & + & + & & + \\
\hline >zomerextremen & $\begin{array}{l}\text { zie winter- en } \\
\text { zomerneerslag }\end{array}$ & & & & & & & & \\
\hline \multirow[t]{4}{*}{ wind } & golfslag & & & & & & + & + & + \\
\hline & salt-spray & & & & + & + & + & & + \\
\hline & resuspensie/lichtlimitatie & & & & & + & + & + & + \\
\hline & zie ook stratificatie & & & & & & & & \\
\hline egalisering & afstroming & + & + & + & + & + & & & + \\
\hline \multirow[t]{2}{*}{ grondwateronttrekking } & droogval & + & + & & + & & $+\mathrm{kl}$ & & + \\
\hline & peildynamiek & + & + & + & + & + & + & + & + \\
\hline \multirow[t]{3}{*}{ piekafvoer } & afvoerdynamiek & + & + & + & & & & & \\
\hline & waterbeweging & + & + & + & & & & & \\
\hline & inundatie & + & + & + & $(+)$ & & & & \\
\hline \multirow[t]{2}{*}{ peilwisseling } & resuspensie/lichtlimitatie & & & + & & + & + & + & + \\
\hline & zie ook peildynamiek & & & & & & & & \\
\hline \multirow[t]{3}{*}{ verdroging } & indamping & + & + & & + & + & + & & + \\
\hline & zoute kwel & & & & + & & + & & + \\
\hline & zie ook peildynamiek & & & & & & & & \\
\hline invloed basisafvoer & $\begin{array}{l}\text { zie ook peildynamiek, } \\
\text { afvoerdynamiek en } \\
\text { waterbeweging }\end{array}$ & & & & & & & & \\
\hline $\begin{array}{l}\text { verwijderen } \\
\text { oeverbegroeiing }\end{array}$ & thermofilie & $+\mathrm{kl}$ & $+\mathrm{kl}$ & & +sch. & + & & & \\
\hline \multirow[t]{2}{*}{ profielaanpassing } & loopontwikkleing & + & + & + & & & & & \\
\hline & erosie-sedimentatie & + & + & + & & & + & + & \\
\hline taludaanpassing & taludontwikkeling & + & + & + & + & + & + & & + \\
\hline verzuring & zuur-base evenwicht & & + & & + & & + & & \\
\hline verharding & ionenverrijking & & + & + & + & + & + & & \\
\hline saprobiëring & zuurstofhuishouding & + & + & + & + & + & + & & \\
\hline \multirow[t]{2}{*}{ eutrofiëring } & nutriëntenhuishouding & + & + & + & + & + & + & + & + \\
\hline & zie ook zuurstof-hh & & & & & & & & \\
\hline vergiftiging & milieuvreemde stoffen & + & + & + & + & + & + & + & + \\
\hline \multirow{3}{*}{ onderhoud } & macrofyten (maaien) & + & + & & + & + & & & + \\
\hline & substraat (baggeren) & + & + & & + & + & & & + \\
\hline & zie ook zuurstof-hh & & & & & & & & \\
\hline soortbeheer & invasiviteit & + & + & + & + & + & + & + & + \\
\hline
\end{tabular}

Leqenda: $\mathrm{kl}$. = kleine wateren, sch. = schaduw, $h \mathrm{~h}=$ huishoudina 
Wanneer menselijke activiteiten in een waterlichaam plaatsvinden dan heeft dat bijna altijd gevolgen voor meer dan één factor in het waterecosysteem. Stressoren staan nooit op zichzelf, noch werken ze slechts in op één factor. Stressoren werken meestal in op combinaties van milieufactoren en wijzigen de ecosysteemtoestand. De meeste Nederlandse oppervlaktewateren staan gelijktijdig bloot aan meerdere stressoren (Dos Reis Oliveira et al. 2018). Een beek in een landbouwgebied ondervindt bijvoorbeeld stress door de toevoer van voedingsstoffen en slib, wat leidt tot eutrofiëring en verslibbing, door biociden, wat leidt tot vergiftiging, door droogte en piekafvoeren, wat leidt tot homogenisering van het profiel en substraatinstabiliteit (vorm- en structuurverlies), door het ontbreken van beekbegeleidende vegetatie, wat leidt tot een toename van de beekwatertemperatuur, enzovoorts. Iedere stressor kan individueel soorten doen verdwijnen. De gelijktijdige werking van meerdere stressoren kan echter effecten van individuele stressoren verzwakken, niet beïnvloeden of versterken. Meestal grijpen stressorcombinaties ('multiple stress') in op een nog groter aantal factoren en kunnen zo de ecosysteemtoestand drastischer veranderen in vergelijking met een enkelvoudige stressor (o.a. Christensen et al. 2006, Jackson et al. 2016).

Belangrijk voor het beoordelen van ecosysteemtoestanden in relatie tot stressoren is gekwantificeerde kennis van de ranges van ecologische sleutelfactoren die horen bij de verschillende toestanden. Deze waarden geven de grenzen (drempelwaarden) aan waarbinnen de milieufactor moet blijven om de ecosysteemtoestand te handhaven. De oorzaken van stressoren kunnen in direct verband worden gebracht met de ecologische sleutelfactoren (Figuur 10.7). Daarmee worden allerlei specifieke relaties tussen bijvoorbeeld klimaatverandering en temperatuur, licht, stroming en droogval veel eenvoudiger. Deze vereenvoudiging van het grote aantal verbanden via de causale werking van de stuur- en sleutelfactoren op de ecosysteemtoestand en functies in het ecosysteem vormt de kern van de stroomgebiedsbrede ecologische systeemanalyse (zie ook Leps et al. 2015).

\section{FIGUUR 10.7}

De werking van stressoren (blauw) op combinaties van ecologische sleutelfactoren.

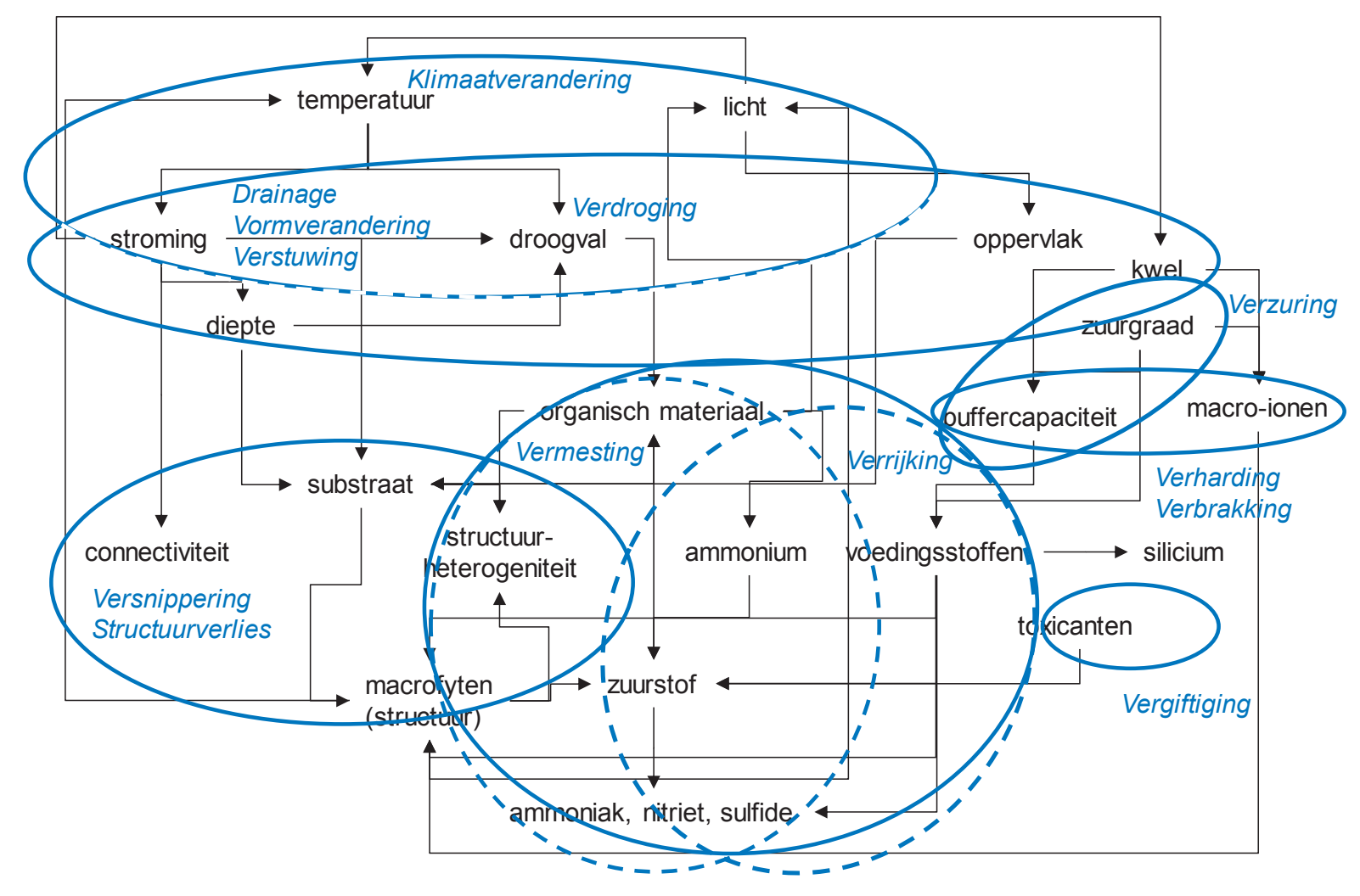


Tenslotte is de range van de parameterwaarden die een milieufactor kan aannemen van groot belang. Ook hierin is een sterke hiërarchie aanwezig. In sterk brakke wateren overheerst bijvoorbeeld de chloride-concentratie, die dusdanige fysiologische aanpassingen vraagt van de organismen dat andere factoren van ondergeschikt belang worden. Is de chlorideconcentratie lager, dan wordt de rol van de andere milieufactoren steeds sterker, terwijl in het lage bereik chloride nauwelijks een rol van betekenis speelt voor organismen.

\subsection{Biologische respons \\ 10.3.1 Indicatoren}

Biologische of ecologische indicatoren zijn meetbare eigenschappen van de structuur, samenstelling, functie of functioneren van een soort of gemeenschap, bijvoorbeeld het voorkomen van bepaalde soorten, de dominantie van een soort en de functionele kenmerken van een groep soorten, zoals de manier van voedsel vergaren, enzovoorts (Niemi \& McDonald 2004). Indicatoren kunnen twee verschillende rollen vervullen: enerzijds kunnen ze natuurlijke milieuomstandigheden indiceren en zo informatie geven over de staat waarin het systeem verkeert (positieve indicator), of anderzijds aangeven of er sprake is van bepaalde verstoringen of stress (negatieve indicator).

Geschikte biologische indicatoren voldoen aan de volgende criteria (Bonada et al. 2006):

- Ze zijn in (bijna) elk waterlichaam aanwezig.

- Ze kunnen met relatief eenvoudige, goedkope middelen worden verzameld of gemeten.

- Ze omvatten een zeer soortenrijke groep, waardoor een breed spectrum aan reacties op milieuomstandigheden kan optreden.

- Ze bevatten veel abundant voorkomende soorten, die gevoelig zijn voor verschillende vormen van beïnvloeding.

- De taxonomie, ten minste voor families en genera, is relatief goed bekend.

- Ze hebben een beperkte actieradius, waardoor specifieke uitspraken gedaan kunnen worden over bepaalde locaties.

- Ze kunnen een lange levenscyclus hebben, waardoor langere-termijn-effecten kunnen worden opgemerkt.

In principe kan een indicator geselecteerd worden op alle hiërarchische niveaus binnen een ecosysteem, van een onderdeel van een organisme (gen, cel, weefsel), tot individu, populatie of de gehele levensgemeenschap en de kenmerken van het functioneren daarvan (Cairns et al. 1993, Niemi \& McDonald 2004). Vaak ligt in het waterbeheer de nadruk op soorten (presentie of abundantie) of gemeenschappen (relatie tussen soorten of verhouding van hun functionele eigenschappen). De samenstelling van de gemeenschap geeft informatie over de staat waarin het systeem verkeert; bijvoorbeeld de verhouding tussen bepaalde soorten of functionele kenmerken. Voedingsgroepen geven bijvoorbeeld informatie over de trofische structuur van de gemeenschap.

Een indicator heeft specifieke aanpassingen (functionele kenmerken) aan bepaalde milieu-omstandigheden, bijvoorbeeld het verloop van de levenscyclus, manier van voedsel vergaren, type voortbeweging of tolerantie voor lage zuurgraad. Ze komen daardoor alleen voor op specifieke gedeelten van een gradiënt in milieuvariabelen (Figuur 10.8).

\section{FIGUUR 10.8}

Het voorkomen van taxa langs een stress- of verstoringgradiënt. De complete gradiënt kan het beste beschreven worden aan de hand van de taxa A, B en C (aangegeven met zwarte lijnen). Overige taxa (stippellijnen) zijn minder geschikt.

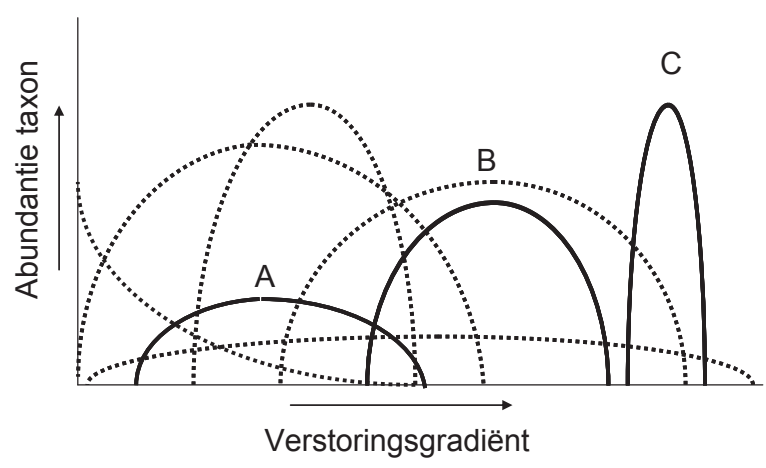


Naast de optima zijn ook de grenswaarden waarbinnen soorten succesvol overleven van belang. Grenswaarden in het milieu bakenen de capaciteit van de functionele eigenschappen van soorten af en bepalen daarmee het al dan niet voorkomen. Op het niveau van het ecosysteem wordt een grenswaarde gezien als het punt waarop regulerende terugkoppelingsmechanismen in het ecosysteem overgenomen worden door deregulerende terugkoppelingen (Briske et al., 2006). Op dit punt wordt de maximale veerkracht overschreden en treedt degradatie op. Ook niet alle factoren zijn voor alle soorten van (gelijk) belang. Factoren die er toe doen en grenswaarden daarvan kunnen tussen soorten sterk verschillen en geven informatie over de kwetsbaarheid van de soort. Extremen in omstandigheden van deze bepalende factoren zijn meestal de oorzaak van het verdwijnen van soorten.

Deze specificiteit kan tegelijkertijd ook een probleem vormen, een indicator moet wel te monitoren zijn. Een soort die wijd verspreid voorkomt en meer abundant voorkomt heeft een hoge trefkans in reguliere monitoring dan een zeldzame, in lage dichtheden voorkomende soort. De algemene soort is echter vaak veel minder kritisch en dus minder informatief (Verdonschot et al. 2003). De indicatiewaarde van soorten is per watertype verschillend, daardoor kan een soort binnen het ene watertype gelden als een positieve indicator, maar binnen een ander watertype gelden als een teken van stress. In permanente stromende wateren worden bijvoorbeeld als gevolg van een toename van stress de langlevende soorten vervangen door kortlevende soorten. Het abundant voorkomen van langlevende soorten indiceert in dat geval een lage mate van stress, terwijl dominantie van kortlevende soorten wijst op sterke stress. Echter, in van nature droogvallende beken is de indicatiewaarde precies andersom: als gevolg van het optreden van droogval komen er alleen kortlevende soorten voor, terwijl wanneer er langlevende soorten aangetroffen worden, dit zou wijzen op een verstoring van de hydrologie van de beek (Davies \& Jackson 2006). De indicatiewaarde die geldt voor een bepaald watertype is dus niet zomaar te gebruiken voor een ander watertype.

Er zijn verschillende technieken ontwikkeld om de ecologische stressindicatie van waterlichamen te bepalen. Deze zijn op te delen in enkelvoudige indices, waarbij de nadruk vooral ligt op de toleranties of preferenties van soorten of de soortenrijkdom van een waterlichaam en de recenter ontwikkelde meervoudige indicatormethoden, die zich richten op of verschillende onderdelen van de gemeenschap, of de koppeling tussen de biologie en het verloop van ecosysteemfuncties of de stressorspecificiteit per taxon.

De ontwikkeling van stress tolerantie- of gevoeligheidsindices gebaseerd op individuele taxa stamt uit de eerste helft van de vorige eeuw. Dit type indices maakt gebruik van de ecologische preferentie/tolerantie van soorten, ofwel het niche concept. Het gebruik van het niche optimum en de niche breedte van één fysiologische of morfologische niche-dimensie, zoals zuurstofgehalte, droogval, $\mathrm{pH}$, hoeveelheid organisch materiaal, voedselrijkdom en stroomsnelheid. Deze factoren kunnen gekoppeld worden aan menselijke beïnvloeding: organische belasting, verdroging, verzuring, saprobiëring, eutrofiëring en hydrologische/morfologische verstoring. Vaak wordt ook een maat van soortenrijkdom of samenstelling van de (een deel van de) levensgemeenschap opgenomen. Voorbeelden van tolerantie- en gevoeligheidsindices die frequent bij macrofauna gebruikt worden zijn de Saprobie-index van Zelinka \& Marvan (1979), Biological Monitoring Working Party en de hiervan afgeleide voor soortenrijkdom gecorrigeerde Average Score Per Taxon (Armitage et al. 1983), Begian Biotic Index (De Pauw \& Vanhooren 1983), Danish Stream Fauna Index (Skriver et al. 2000) en de Duitse saprobie-index (DIN 38 410). Een probleem met het gebruik van stress tolerantie- en gevoeligheidsindices is dat de responscurve van een taxon langs een bepaalde gradiënt van verstoring niet a priori te voorspellen is. In de praktijk blijkt dan ook vaak dat de indices vooral voor extremen indicatief zijn, terwijl er een grote 'middengroep' overblijft die weinig informatie geeft over de stressoren door andere (a)biotische factoren gestuurd wordt.

In de tweede helft van de vorige eeuw kwam de nadruk steeds meer te liggen op het gebruik van informatie over de gemeenschap, met name de soortenrijkdom en samenstelling (Bailey et al. 2004). Aan de hand van veranderingen in de levensgemeenschap kan generieke stress opgemerkt worden. Aangezien in het algemeen de diversiteit afneemt bij een toename van menselijke verstoring, biedt dit mogelijkheden voor een generieke stress-analyse (Figuur 10.9). 
FIGUUR 10.9

Bij toenemende menselijke verstoring daalt de biodiversiteit van een waterlichaam.

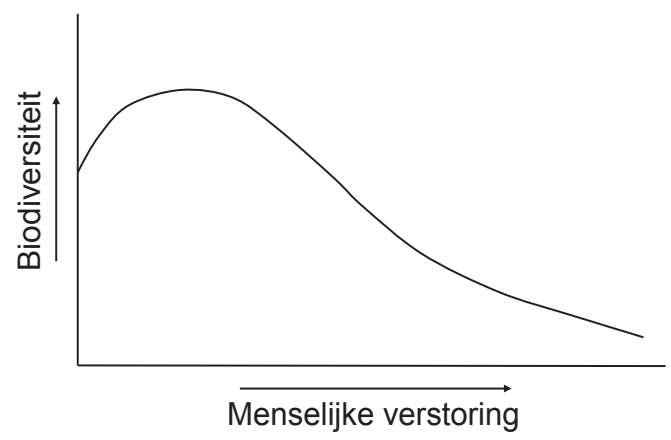

Het blijkt echter dat de hoogste soortenrijkdom vaak niet wordt gevonden onder vrijwel natuurlijke omstandigheden, maar bij een lichte mate van verstoring, wat problemen kan opleveren wanneer puur het aantal soorten gebruikt wordt bij de waardering van locaties (Nijboer 2006). Soortenrijkdom is het aantal soorten per gestandaardiseerde bemonsteringsinspanning, zoals geschepte lengte met een standaard-macrofaunanet. Het bepalen van de werkelijke soortenrijkdom op een locatie lijkt dus eenvoudig, maar blijkt in de praktijk lastig omdat het een grote bemonsteringsinspanning vergt. Het probleem is namelijk dat veel soorten in lage dichtheden voorkomen en dat niet alle soorten met dezelfde bemonsteringstechniek goed te verzamelen zijn. Daarnaast is het aantal soorten erg gevoelig voor het aantal individuen per monster en het aantal monsters dat genomen is (Gotelli 2008). Standaardisatie van de bemonstering op basis van het aantal aangetroffen soorten en hun abundantie is dus essentieel om vergelijking tussen locaties mogelijk te maken. Hiervoor worden onder andere diversiteitsindices gebruikt. Veel gebruikte diversiteitindices zijn de Shannon-Wiener index en de Simpson index, maar er zijn nog een groot aantal andere geschikte indices ontwikkeld (Krebs 1999, Magurran 2004).

Gekoppeld aan het gebruik van soortenrijkdom als generieke stressindicator is het gebruik van het aantal zeldzame soorten. Om verschillende redenen is dit echter een hoogst problematische benadering (Flather \& Sieg 2007). Ten eerste is zeldzaamheid vaak verbonden met een lage trefkans en leidt dus tot monitoringsproblemen (Keizer-Vlek 2009). Ten tweede is zeldzaamheid is afhankelijk van de schaal waarop gekeken wordt. Een soort kan op landelijke schaal zeldzaam zijn maar op Europese schaal algemeen. Zeldzaamheid kan ook voortvloeien uit de zeldzaamheid van een habitat, waardoor een soort lokaal algemeen kan zijn. Ten derde is zeldzaamheid gerelateerd aan de grootte van een habitat, des te groter het habitat des te meer zeldzame soorten het bevat. Ten vierde kan de status van een soort variëren in de tijd, zeldzame soorten kunnen algemener worden en algemene zeldzamer.

Na 1970, als gevolg van het toegenomen vermogen van computers en de daaraan gekoppelde mogelijkheden voor de toepassing van wiskundige methoden (multivariate analyse technieken, voorspellende modellen e.d.), kwam de levensgemeenschap meer centraal te staan, en met name de vergelijking tussen de gemeenschappen van verstoorde locaties en de referentie of natuurlijke samenstelling (Bailey et al. 2004). In veel van de huidige biomonitoringsmethoden worden verschillende onderdelen van een biologisch systeem meegewogen, waardoor verschillende aspecten van het ecosysteem aan bod komen (Barbour et al. 1999, Karr \& Chu 1999).

Voor het indiceren van individuele stressoren (diagnose) zijn drie van de op dit moment beschikbare technieken relevant, namelijk: 1.) multimetric indices, 2.) multivariate technieken, en 3.) ecologische preferenties en biologische levenskenmerken of -strategieën. Bij deze technieken ligt de nadruk op de samenstelling van de gemeenschap en de identiteit van de afzonderlijke taxa onder bepaalde omstandigheden (Figuur 10.10). 


\section{FIGUUR 10.10}

Drie typen benaderingen om generieke of specifieke stress te bepalen gebaseerd op de soortensamenstelling van de gemeenschap en de identiteit van individuele soorten, met elk een andere benaderingswijze: multimetric indices combineren verschillende aspecten van de gemeenschap (zodat verschillende onderdelen van het ecosysteem aan bod komen), zoals soortenrijkdom, tolerantie van soorten, functionele eigenschappen tot een score (de natuurwaardering), die eventueel vergeleken wordt met de referentiesituatie. Multivariate technieken vergelijken de samenstelling van de levensgemeenschap bij een bepaalde mate van verstoring met de referentiesituatie en bepalen zo in hoeverre deze afwijkt, waarna een mate van generieke stress kan worden vastgesteld. Wanneer ook de stressoren worden toegevoegd kan ook de mate van invloed van iedere stressor worden aangegeven. Stressor identificatie aan de hand van levenskenmerken is erop gebaseerd dat bepaalde functionele kenmerken (o.a. grootte, lichaamsvorm, levenscyclus, reproductie) of bepaalde ecologische preferenties/toleranties veel voorkomen bij bepaalde milieu-omstandigheden, waardoor op basis van daarvan een uitspraak gedaan kan worden over de heersende omstandigheden en de specifieke stressoren.

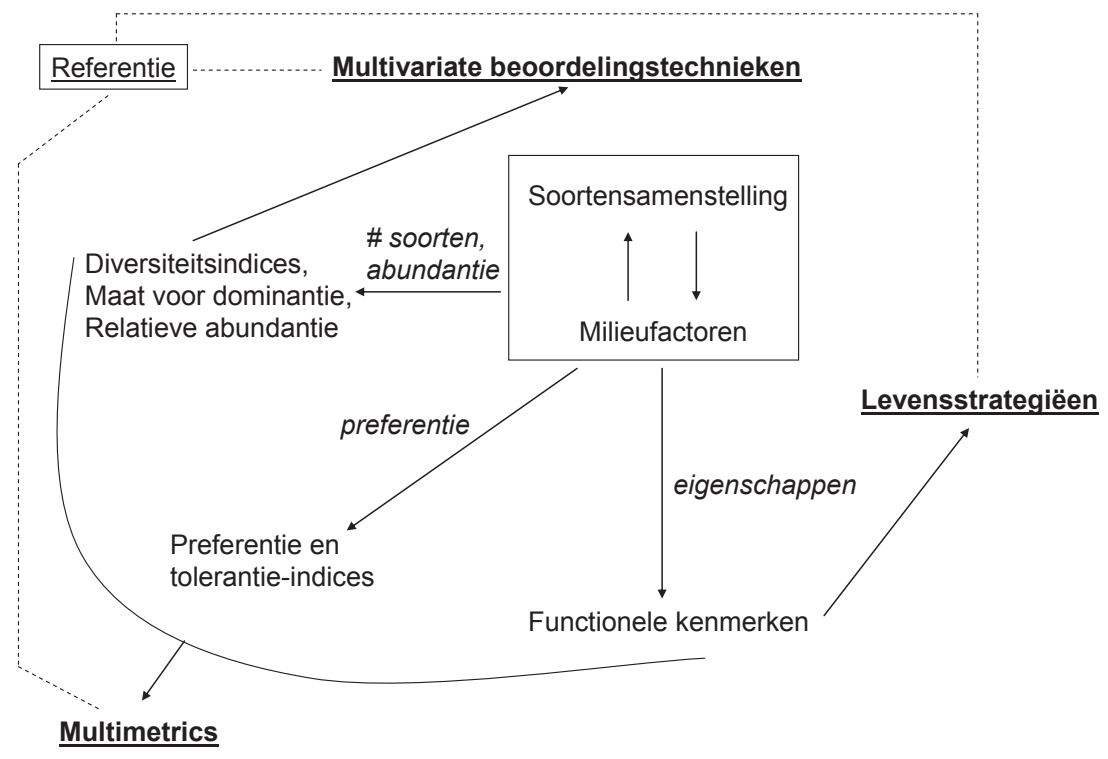

\subsubsection{Multimetric indices}

Een metric is een meetbaar onderdeel of proces binnen een biologisch systeem waarvan aangetoond is dat het op een voorspelbare manier verandert als gevolg van menselijke verstoring (Barbour et al. 1999, Karr \& Chu 1999). Veel gebruikte metrics om ecologische kwaliteit of generieke stress te waarderen zijn bijvoorbeeld het aantal soorten, de som van het aantal Ephemeroptera, Plecoptera en Trichoptera taxa, diversiteitsindices, aandeel van bepaalde voedingsgroepen en tolerantie-indices.

Multimetric indices (MMI) zijn gebaseerd op een combinatie van een aantal van deze individuele metrics. Hering et al. (2006a) onderscheiden twee typen multimetric indices. Het eerste type metric wordt gebruikt voor het bepalen van de generieke stress. Het tweede type is een stressor-specifieke benadering. Een stressor-specifieke multimetric index kan alleen worden opgesteld wanneer een gradiënt van een bepaalde stressor of stressoren aanwezig is en de autoecologie van de aangetroffen fauna of flora goed bekend is. De multimetric benadering start met de selectie en evaluatie van een aantal voor een bepaald watertype geschikte metrics.

Deze metrics worden geijkt op een serie wateren met toenemende mate van verstoring, zodat drempelwaarden vastgesteld kunnen worden, waarmee een indeling gemaakt kan worden van goed (natuurlijke of referentiesituatie) naar slecht (zwaar gedegradeerd). Vervolgens kan de ontwikkelde MMI gebruikt worden om nieuwe locaties die behoren tot hetzelfde watertype te beoordelen (Barbour et al. 1999). 
De ontwikkeling van een MMI voor een bepaalde stressor verloopt over het algemeen volgens een vast patroon van selectie van geschikte metrics en aggregatie hiervan tot een gecombineerde index (Figuur 10.11). Er zijn enorm veel potentiële metrics, daarom is het belangrijk de meest relevante te selecteren voor het gebruik in een multimetric index. Een individuele metric moet aan verschillende criteria voldoen om voldoende informatief te zijn (Barbour et al. 1999, Stoddard et al. 2008):

- Ecologisch relevant met betrekking tot de te monitoren levensgemeenschap en het doel van de studie (een kenmerk of taxon moet wel voorkomen of een reële trefkans hebben op de locatie waar het onderzoek plaatsvindt -> een metric die werkt voor een bepaalde regio, hoeft niet geschikt te zijn voor andere regio met andere soorten en landschappen). Macrofauna is vaak de meeste geschikte groep, maar soms is voor bepaalde stressoren het gebruik van diatomeeën, macrofyten of vissen meer geschikt (Hering et al. 2006b).

- Voldoende variatie in data van verschillende monsterlocaties (brede data range).

- Reproduceerbaar (temporele stabiliteit).

- Gevoelig voor stressoren en een reactie hierop, die te onderscheiden is van de natuurlijke variatie in de levensgemeenschap (bijvoorbeeld natuurlijke gradiënten, jaarlijkse fluctuaties in populaties).

- Onafhankelijk van andere metrics in de index.

Het voordeel van het combineren van individuele metrics is dat deze samen over het algemeen een beter beeld geven van de respons van de levensgemeenschap op stress, omdat verschillende aspecten van het biologische systeem belicht kunnen worden (Barbour et al. 1999, Lücke \& Johnson 2009). Belangrijk is dan ook dat wanneer verschillende metrics in een multimetric index gecombineerd worden, er verschillende elementen en processen uit het ecosysteem of de levensgemeenschap worden opgenomen. De volgende categorieën worden vaak gebruikt (Barbour et al. 1999, Hering et al. 2006a):

- Rijkdom/diversiteit: aantallen soorten, genera of hogere taxonomische niveaus binnen een bepaalde taxonomische groep, inclusief het aantal taxa en diversiteitsindices.

- Samenstelling: relatieve aandeel van een bepaald taxon of taxonomische groep ten opzichte van het aantal individuen; dominantie, verhoudingen tussen groepen e.d. gebaseerd op aantal taxa of abundantie.

- Gevoeligheid/tolerantie: metrics gerelateerd aan taxa waarvan bekend is dat ze gevoelig/tolerant zijn voor een bepaalde stressor of verandering in milieuomstandigheden, gebaseerd op aan-/afwezigheid of abundantie.

- Functionele kenmerken: metrics gerelateerd aan de ecologische functie van taxa (afgezien van hun gevoeligheid voor stressoren), zoals voedingsgroepen, habitatpreferentie, stromingspreferentie, eigenschappen van hun levenscyclus, grootte etc., gebaseerd op aantal taxa of abundantie.

Karr \& Chu (1999) voegen hier nog een categorie aan toe, namelijk een maat van de conditie van individuen van een soort (bijvoorbeeld de hoeveelheid misvormde Chironomiden in een populatie). Deze categorie is echter voor veel groepen ongewervelden moeilijk meetbaar, maar voor bijvoorbeeld vissen relevant in verband met blootstelling aan toxische stoffen.

Uiteraard spelen in veel systemen meerdere stressoren een rol, al dan niet verweven met elkaar. De ideale multimetric index is tegelijkertijd diagnostisch voor deze verschillende stressorgradiënten. Losse elementen van zo'n index geven de effecten van individuele stressoren weer en gecombineerd wordt de algehele degradatie van het ecosysteem weergegeven. Op dit moment is de kennis van de autecologie van aquatische organismen nog niet zo ver gevorderd dat een multidimensionale index tot de mogelijkheden behoort, maar MMI's voor verschillende stressorgradiënten worden veel en met succes gebruikt in de VS (Rapid Bioassessment Protocols, zoals de Benthic Index of Biological Integrity (B-IBI), Karr \& Chu 1999) en recentelijk ook in Europa (bijv. AQEM, Hering et al. 2004). Het merendeel van de MMI's is ontwikkeld voor stromende wateren, maar er zijn ook indices ontwikkeld voor onder andere meren (Lewis et al. 2001, Blocksom et al. 2002) en poelen (Menetrey et al. 2005, Solimini et al. 2008, Trigal et al. 2009). Verdonschot \& Verdonschot (2010) geven een lijst van typen metrics die potentieel bruikbaar zijn voor de Nederlandse situatie. 


\section{FIGUUR 10.11}

Ontwikkelen van een MMI in 5 stappen (Barbour et al. 1999): 1. Classificatie watertypen: op basis van biologische data worden referentie-locaties gegroepeerd, 2. Kandidaat metrics relevant voor desbetreffende levensgemeenschap worden geselecteerd aan de hand van een stressorgradiënt 3. Evaluatie en kalibratie, hieruit volgen kern-metrics, diegene met voldoende gevoeligheid voor verstoring en die voldoende informatie geven over de ecologische gevolgen voor levensgemeenschap van verstoring. 4 . Kern-metrics, waarvan waarden variëren, worden getransformeerd naar een dimensieloos getal en vervolgens geaggregeerd. 5. Bepalen van de drempelwaarden van de index, zodat onderscheid gemaakt kan worden tussen meer en minder stress. Stippellijnen geven aan dat de informatie van de individuele metrics gebruikt kan worden bij het vinden van de oorzaken van de verstoring.

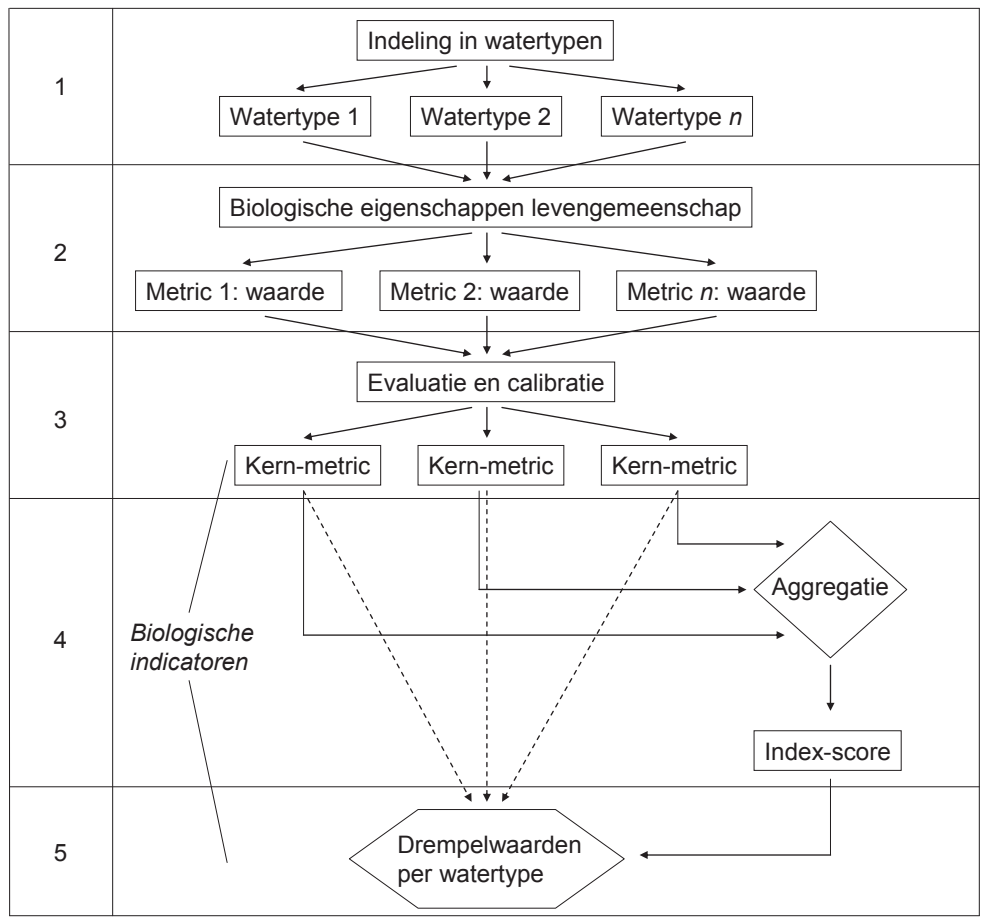

\subsubsection{Multivariate technieken}

Multivariate technieken bepalen de mate van stress aan de hand van een vergelijking tussen de in het te onderzoeken waterlichaam aangetroffen levensgemeenschap en de samenstelling die verwacht wordt wanneer er sprake is van geen menselijke verstoring: de 'reference condition approach' (Bailey et al. 2004). Alhoewel naast deze referentiebenadering ook gewerkt kan worden met gradiënten in ontwikkeling, zoals in de cenotypen benadering gebruikelijk is (Verdonschot 1990).

Er zijn diverse modellen ontwikkeld waarmee de levensgemeenschap van een locatie beoordeeld kan worden. Alle modellen gebruiken cluster- en/of ordinatietechnieken om de overeenkomsten te bepalen tussen de levensgemeenschappen van verschillende locaties (Figuur 10.12).

Het River InVertebrate Prediction And Classification System (RIVPACS; Wright et al. 1989), en het hiervan afgeleide AUStralian RIVer Assessment Scheme (AUSRIVAS; Simpson \& Norris 2000) en het voor meren ontwikkelde BEnthic Assessment of SedimenT model (BEAST; Reynoldson et al. 1997) classificeren referentielocaties met behulp van clustertechnieken in groepen met een vergelijkbare taxonsamenstelling. Hiervoor worden locaties als replica's gebruikt in plaats van meerdere monsters van één locatie. Het verschil tussen de referentielocaties binnen een cluster geeft de 'natuurlijke' variatie aan binnen het watertype aan. Vervolgens worden de milieuvariabelen geselecteerd die deze groepen referentiewateren het beste karakteriseren. Voor elke nieuw te beoordelen locatie kan nu op basis van de in dat waterlichaam gemeten milieuvariabelen een voorspelling gemaakt worden van de samenstelling van de levensgemeenschap wanneer deze een referentiekwaliteit had gehad. 
In RIVPACS en AUSRIVAS wordt vervolgens de verwachting berekend dat de te beoordelen locatie bij elk van de afzonderlijke referentiegroepen uit de clustering hoort, waarna in de uiteindelijke berekening van de voorspelde levensgemeenschap deze verwachting wordt meegewogen. Het verschil tussen de geobserveerde taxonsamenstelling en de te verwachten taxa geeft tenslotte een indicatie van de kwaliteit, in feite vergelijkbaar met de mate van stress, van het bemonsterde waterlichaam. Wanneer bijna alle voorspelde taxa op de locatie voorkomen (in de praktijk zijn vrijwel altijd een aantal taxa afwezig) is de ratio tussen aangetroffen en verwachte taxa ongeveer 1. In BEAST wordt alleen het meest gelijkende referentiecluster gebruikt voor de vergelijking met de te beoordelen locatie. De mate van de afwijking ten opzichte van het meest gelijkende cluster geeft de staat aan waarin de nieuwe locatie zich bevindt.

De classificatiestap, waar referentielocaties vooraf gegroepeerd worden en deze groepen gekoppeld worden aan de milieuomstandigheden op die locaties, wordt soms gezien als suggestief. Het recentere Assessment by Nearest Neighbour Analysis (ANNA; Linke et al. 2005) koppelt de referentielocaties en de te beoordelen locatie zonder de referenties te groeperen. Gebaseerd op de milieuvariabelen gemeten op de afzonderlijke locaties worden de overeenkomsten berekend tussen de te beoordelen locatie en de afzonderlijke referentielocaties. Vervolgens wordt de fauna van de te beoordelen locatie voorspeld op basis van de meest gelijkende referentielocaties en wordt er een vergelijking gemaakt tussen waargenomen en verwachtte taxa analoog aan RIVPACS/AUSRIVAS.

Het in Nederland ontwikkelde EKOO volgt een andere benaderingswijze (Verdonschot 1990, Verdonschot \& Nijboer 2000). In plaats van het beschrijven van alleen de referentieomstandigheden, worden alle (dus ook de gedegradeerde) stadia waarin een watertype zich kan bevinden opgenomen in de classificatie. Voor elk watertype wordt zo een serie typen beschreven met een vergelijkbare soortensamenstelling en milieuomstandigheden, de zogenoemde cenotypen. Voor elke nieuw bemonsterde locatie wordt de overeenkomst berekend met de verschillende cenotypen, op basis waarvan een uitspraak gedaan kan worden over de mate van stress en de aard van de stressoren.

\section{FIGUUR 10.12:}

verzicht stappen die doorlopen worden in het beoordelingsproces voor de verschillende multivariate technieken.

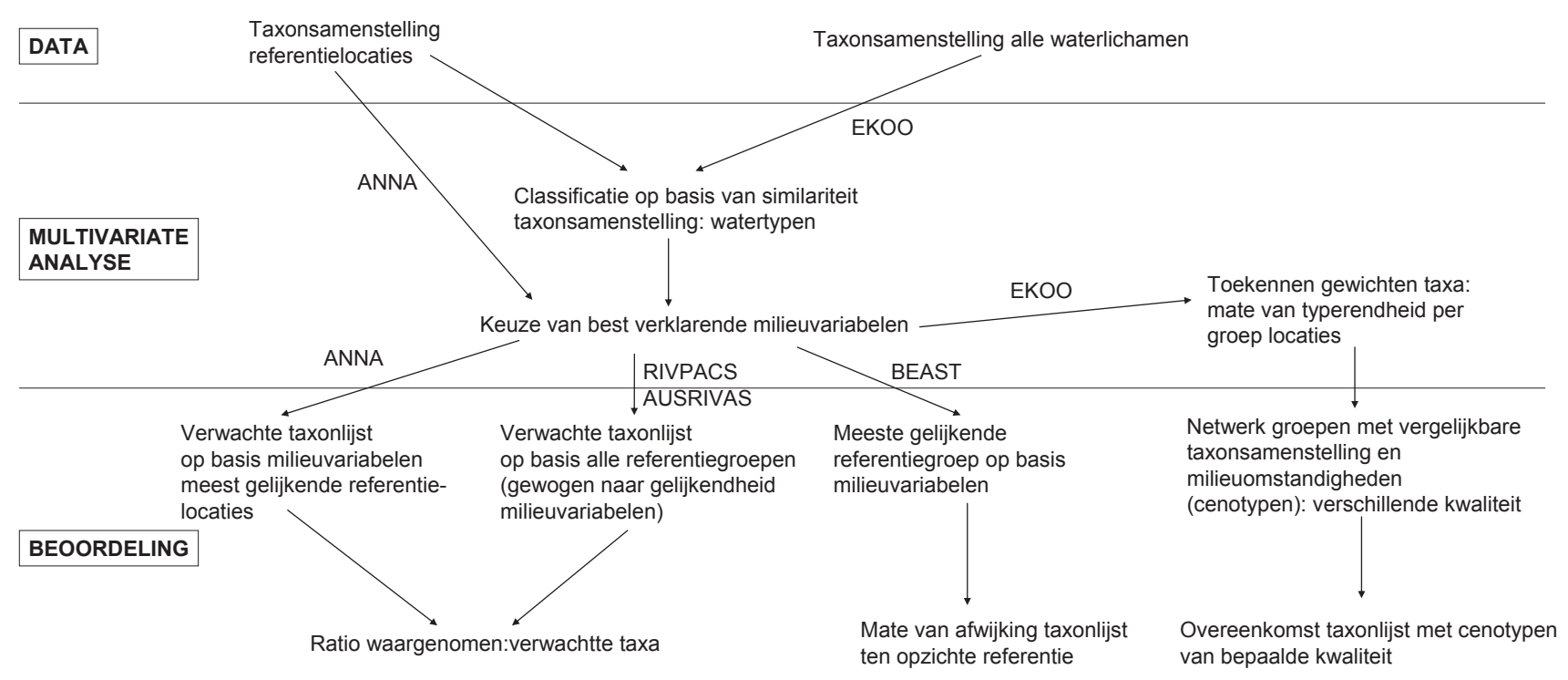




\subsubsection{Functionele eigenschappen, levenskenmerken en ecologische preferenties}

Soorten bezitten een beperkt aantal functionele eigenschappen (o.a. Siepel 1994, Verberk 2008). Functionele eigenschappen van soorten kunnen morfologische, fysiologische, biologische en gedragseigenschappen betreffen. Bij het groeperen van functionele eigenschappen worden vaak twee hoofdgroepen onderscheiden; de ecologische preferenties en de biologische eigenschappen. Biologische eigenschappen refereren aan de levenscyclus, het gedrag, de morfologie en de fysiologie van organismen. Deze biologische eigenschappen hebben soorten om milieuomstandigheden te overleven of juist niet. Voorbeelden zijn ademhaling onder water, zoals kieuwen, een ademhalingsbuis, luchtbel of poreuze huid, en aanpassingen aan stroming, zoals het bezit van een zuignap, verlenging, haakjes of een afgeplat lichaam. Soorten hebben veel meer eigenschappen, eigenschappen om met hulpbronnen om te gaan, om te overleven (K/r-strategie), van de levenscyclus en van de manier van voortplanten. Ze kunnen zichzelf op verschillende manieren voeden, zoals met filtreren, roven, zuigen en verzamelen. Ze kunnen zich ook op allerlei wijzen verspreiden, zoals kruipen, liften, dwarrelen en vliegen. Steeds allemaal aanpassingen om onder bepaalde milieu-omstandigheden te overleven.

Ecologische preferenties zijn de gekwantificeerde vertaling van tolerantiecurves voor milieufactoren, vaak uitgedrukt in fuzzy-coderingen door een bepaald aantal punten toe te kennen naar rato van de indicatie in verschillende klassen waarmee de milieufactor is beschreven. Ecologische preferenties laten de uiting van soorten zien van de biologische eigenschappen, zoals grootte, wijze van reproductie, voedingswijze en manier van voortbewegen, die ze daartoe bezitten en duiden de ecologische niche en functionele rol binnen een ecosysteem.

Ondanks de grote verschillen in biologische eigenschappen dienen deze eigenschappen toch maar een beperkt aantal doelen. Dit betreft de basisfuncties van het omgaan met de ecologische sleutelfactoren, zoals het omgaan met zuurstof en stroming. Maar er zijn ook 'trade-offs': eigenschappen die elkaar uitsluiten. Een investering van een soort in een bepaalde eigenschap kan ten koste gaan van de mogelijkheid tot investering in een andere eigenschap. Functionele eigenschappen staan ook niet los van elkaar, bepaalde combinaties van eigenschappen komen vaak samen voor bij soorten uit hetzelfde milieu (o.a. Verberk 2008). Dit komt doordat verschillende soorten zich gedurende de evolutie door middel van de ontwikkeling van verschillende biologische eigenschappen aan hetzelfde milieu hebben aangepast (o.a. Reiss et al. 2009).

Het kennen van de biologische eigenschappen is dus uiterst belangrijk voor het begrijpen van het functioneren van ecosystemen. De biologische eigenschappen houden verband met vier mechanismen voor soorten om duurzaam te overleven, namelijk het gebruik van hulpbronnen, de interacties met andere organismen, het voltooien van de levenscyclus en het verspreiden (Figuur 10.13).

\section{FIGUUR 10.13}

Voorbeeld van de groepering van functionele eigenschappen van macroinvertebraten.

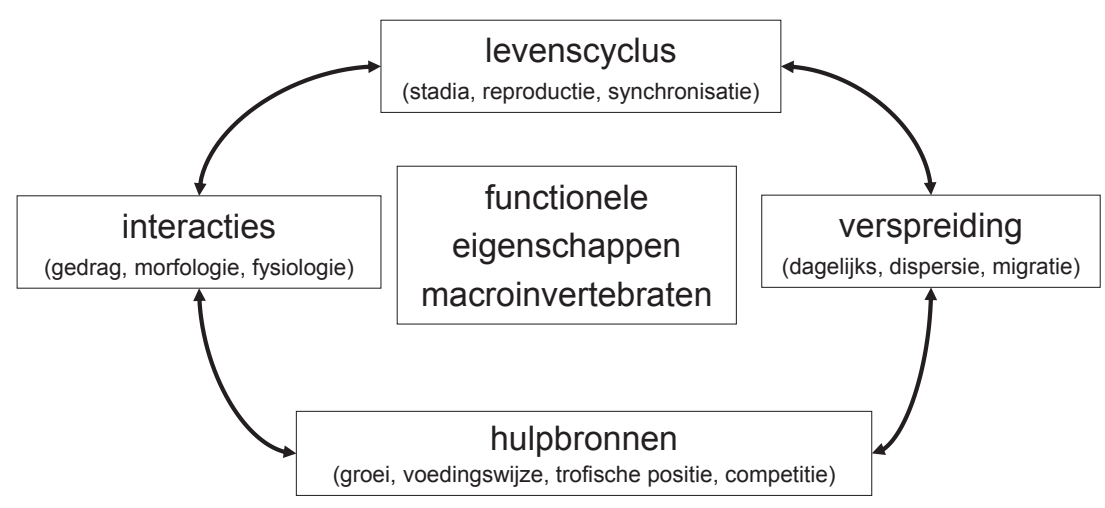


Het is van belang om de biologische eigenschappen te ordenen naar functie in het ecosysteem en hun samenhang te classificeren. Een juiste classificatie heeft grote praktische waarde en is essentieel voor het waterbeheer. Voor het waterbeheer zijn de ecologische preferenties bruikbaar om stressoren te identificeren. Voor het begrip is het belangrijk om de biologische eigenschappen achter de ecologische preferenties te kennen, die verklaren waarom een soort bepaalde preferenties heeft (Figuur 10.14).

\section{FIGUUR $\mathbf{1 0 . 1 4}$}

Voorbeeld van functionele eigenschappen van een soort met biologische eigenschappen en ecologische preferenties.

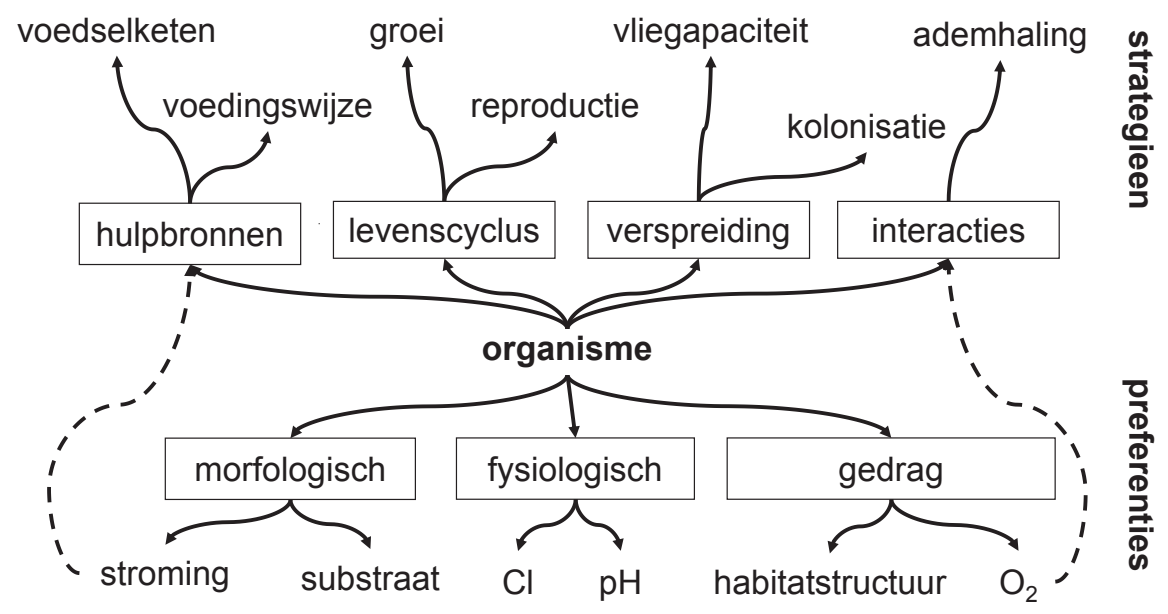

De functionele eigenschappen van soorten hebben, vaak per levensstadium, in ruimte en tijd een relatie met bepaalde abiotische en biotische milieuomstandigheden. De milieuomstandigheden en de veranderingen in deze omstandigheden in de tijd vormen 'habitat templates' voor soorten. In het oppervlaktewatermilieu treden regelmatig veranderingen op, zoals wisselingen in stroomsnelheid, peil, substraatsamenstelling en fysisch-chemische omstandigheden. Evenzo belangrijk zijn de biologische omstandigheden, zoals de aanwezigheid van predatoren, concurrenten of structuurvormers voor macroinvertebraten, zoals waterplanten. De frequentie, omvang en voorspelbaarheid van wisselingen in abiotische en biotische milieuomstandigheden vormt een belangrijk filter in het 'habitat template' concept (Southwood 1977, 1988; Townsend \& Hildrew 1994). Omdat de biotische interacties eveneens van belang zijn wordt hier van 'niche templates' gesproken. In 'niche templates' worden ook de temporele en functionele aspecten van woonplaats en rol van soorten gedurende hun gehele levenscyclus meegenomen. 'Niche templates' bieden inzicht in de relatie tussen ruimtelijke en temporele stabiliteit dan wel variabiliteit en overlevingsstrategieën van soorten (Townsend \& Hildrew 1994).

De samenhang tussen functionele eigenschappen en biodiversiteit is weergegeven in een figuur met horizontaal de mate van constantie in milieuomstandigheden en verticaal de mate van voorspelbaarheid (Figuur 10.15). De linker figuur toont de positie van evenwichten, multiple evenwichten en niet-evenwichten en bijhorende habitattypen, de rechter de functionele groepen en diversiteit (Figuur 10.16). Zo kan bijvoorbeeld de eigenschap van het bezit van een meerjarige levenscyclus bij macroinvertebraten in de figuur worden gepositioneerd. Soorten met een meerjarige levenscyclus zullen zich beter ontwikkelen in niches die in de tijd stabiel zijn, linksboven in beide figuren. Wisselingen in omstandigheden, instabiliteit linksonder, leiden tot het uitfilteren van soorten met een lange levensduur omdat een mismatch optreedt tussen de eigenschappen van soorten en de omstandigheden in de beschikbare niche. 


\section{FIGUUR 10.15}

'Niche template'; de samenhang tussen functionele eigenschappen en biodiversiteit (licht grijs = hoog, grijs = intermediair, donker grijs = laag) (bewerkt naar Townsend, 1989).

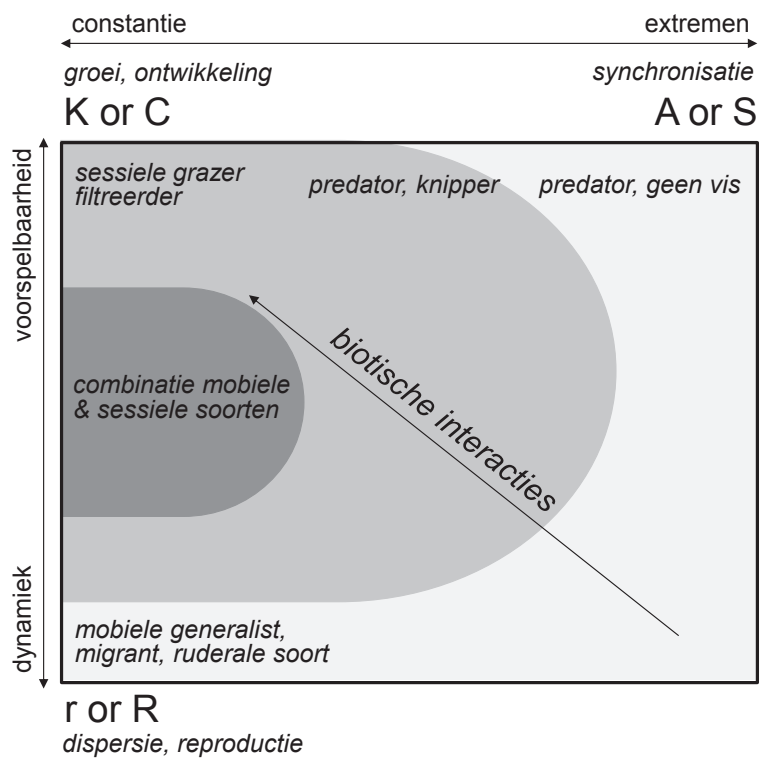

\section{FIGUUR 10.16}

'Niche template'; de samenhang tussen biodiversiteit (licht grijs = hoog, grijs = intermediair, donker grijs = laag) en dynamische, stabiele en extreme milieuomstandigheden (bewerkt naar Townsend, 1989).

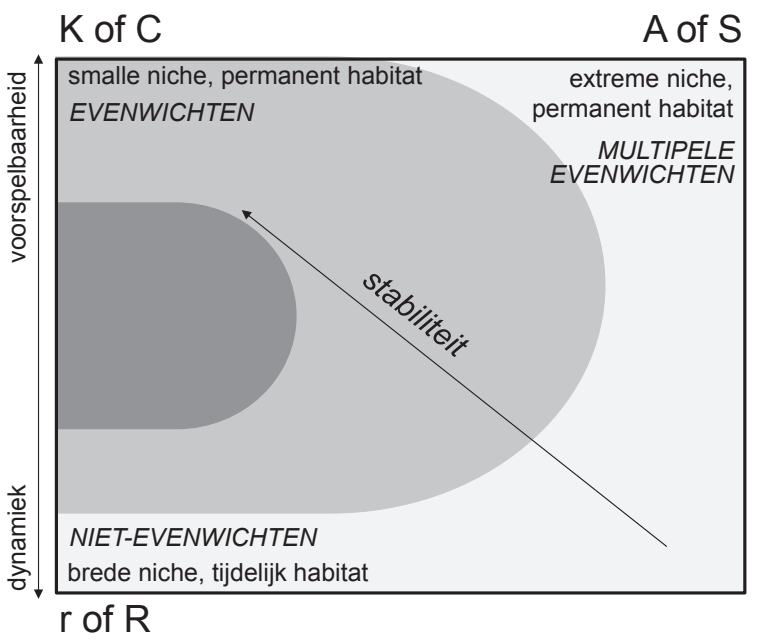

Onderzoek aan de relatie tussen functionele kenmerken van aquatische organismen en milieuomstandigheden maakt een belangrijk deel uit van de theoretische aquatische ecologie, maar wordt recentelijk ook steeds meer toegepast in de biomonitoring (Bonada et al. 2006).

Het principe achter de functionele kenmerken is dat milieu-omstandigheden werken als een 'filter', oftewel kenmerken zijn alleen geschikt onder bepaalde omstandigheden (Poff 1997). De basis van deze benadering wordt gevormd door het eerder genoemde 'habitat template' model van Southwood (1977,1988). Dit model voorspelt dat wanneer de milieu-omstandigheden in een waterlichaam in dynamisch evenwicht zijn, de functionele samenstelling van de levensgemeenschap convergeert naar een dominantie van kenmerken die passen bij de heersende omstandigheden, dus ook stress, onafhankelijk van de soortensamenstelling. 
Stressoren zorgen voor wijzigingen in de heersende milieuomstandigheden, waardoor bepaalde kenmerken verdwijnen uit de levensgemeenschap, terwijl andere verschijnen. Het voorkomen van bepaalde kenmerken of preferenties/toleranties zegt dus iets over de milieuomstandigheden op een locatie (Usseglio-Polatera et al. 2000). Een voorbeeld is het aandeel 'klevers' in een beek. Klevers zijn soorten met morfologische aanpassingen aan hoge stroomsnelheden, zoals een afgeplatte lichaamsbouw, zuignappen om zich vast te houden aan het substraat. Wanneer als gevolg van hydromorfologische verstoring de stroomsnelheid in een beek sterk afneemt, worden soorten met deze kenmerken (die opeens niet meer noodzakelijk zijn) weggeconcurreerd door soorten met andere kenmerken, zoals klimmers. Echter, meer direct is gebruik te maken van soorten die meer of minder voorkeur vertonen voor stroming, waaruit de mate van verstoring van de factor stroming kan worden afgeleid.

Het grote voordeel van het gebruik van functionele of ecologische kenmerken is dat deze meer universeel zijn, dus niet gebonden aan een bepaalde schaal en vaak ook niet aan een watertype. Ze kunnen dus vertaald worden tussen levensgemeenschappen, onafhankelijk van biogeografische regio's, waardoor de informatie op grotere schaal toepasbaar is. Daarnaast geven functionele en ecologische kenmerken informatie over de identiteit van soorten en koppelen zo de aanwezigheid van soorten met het verloop van ecosysteemprocessen. Charvet et al. (2000) onderzochten de bruikbaarheid van functionele kenmerken voor biomonitoring in vergelijking met puur de taxonomische samenstelling van de levensgemeenschap. Het bleek dat langs een gradiënt van milieuomstandigheden functionele kenmerken stabieler waren dan de taxonomische samenstelling van de levensgemeenschap.

Gayraud et al. (2003) hebben onderzocht welke functionele kenmerken het grootste potentieel hebben om menselijke verstoring (gedefinieerd als een combinatie van organische belasting, toxische beïnvloeding, scheepvaart, afname afvoer en kanalisatie) in grote rivieren te indiceren. De volgende kenmerken bleken effectief:

- Maximale grootte

- Aantal nakomelingen per reproductiecyclus

- Aantal reproductiecycli per individu

- Levensduur adulte stadium

- Manier van voortplanting

Broedzorg

- Lichaamsvorm

Voedingswijze

Het toe- of afnemen van functionele kenmerken ten opzichte van een referentie (gemiddeld aandeel onder ongestoorde omstandigheden) kan gebruikt worden voor de diagnose van stress (Carlisle \& Hawkins 2008). Het bleek dat soorten die afnemen na verstoring een andere combinatie van functionele kenmerken hebben dan soorten die toenemen na menselijke beïnvloeding van een waterlichaam. Daarnaast kon aan de hand van een klein aantal kenmerken voorspeld worden of een soort afnam of toenam na verstoring (Figuur 10.17). Deze kenmerken kunnen in principe gebruikt worden bij de diagnose van de stressoren in een waterlichaam.

Een nadeel van de functionele benadering is echter dat er nog veel kennishiaten zijn met betrekking tot de autoecologie van veel soorten. Kenmerken van een bepaalde soort worden daarom vaak als representatief gezien voor bijvoorbeeld een heel genus en als zodanig geschaald, terwijl individuele soorten verschillende kenmerken kunnen hebben. Ook worden de kenmerken meestal gekoppeld aan een bepaald levensstadium, terwijl soorten gedurende hun levenscyclus verschillende eigenschappen kunnen hebben. Daarnaast zijn veel kenmerken niet binair (aan-/afwezig) maar gradueel. Om dit te ondervangen wordt fuzzy-coding gebruikt, een schaling naar affiniteit met een bepaald kenmerk in plaats van binaire indeling.

Vaak is het echter moeilijk de exacte puntenverdeling vast te stellen als een soort geen zeer uitgesproken preferenties heeft. Een probleem van een andere orde is dat het vaak niet mogelijk is om alle individuen in een monster tot op soortniveau te determineren. Er worden dan hogere taxonomische niveaus gebruikt, wat weer leidt tot meer onze- 
kerheid in de toedeling in functionele kenmerken. Tenslotte zorgt ook de fylogenetische of evolutionaire koppeling van sommige kenmerken voor problemen, waardoor een bepaald kenmerk kan optreden zonder dat dit gerelateerd is aan milieuomstandigheden van de habitat van de soort (Poff et al. 2006). Hetzelfde geldt voor interacties tussen individuele kenmerken, die nu vaak als mono-factoriaal benaderd worden terwijl er samenhang tussen kenmerken kan optreden.

\section{FIGUUR 10.17}

Boomdiagram opgesteld op basis van 423 beken in het westen van de Verenigde Staten met wisselde beïnvloeding van het stroomgebied (natuurlijk, verstedelijkt, landbouw). Aan de hand van een klein aantal functionele kenmerken kon afgeleid worden of een beek beïnloed was of niet (Carlisle \& Hawkins 2008).

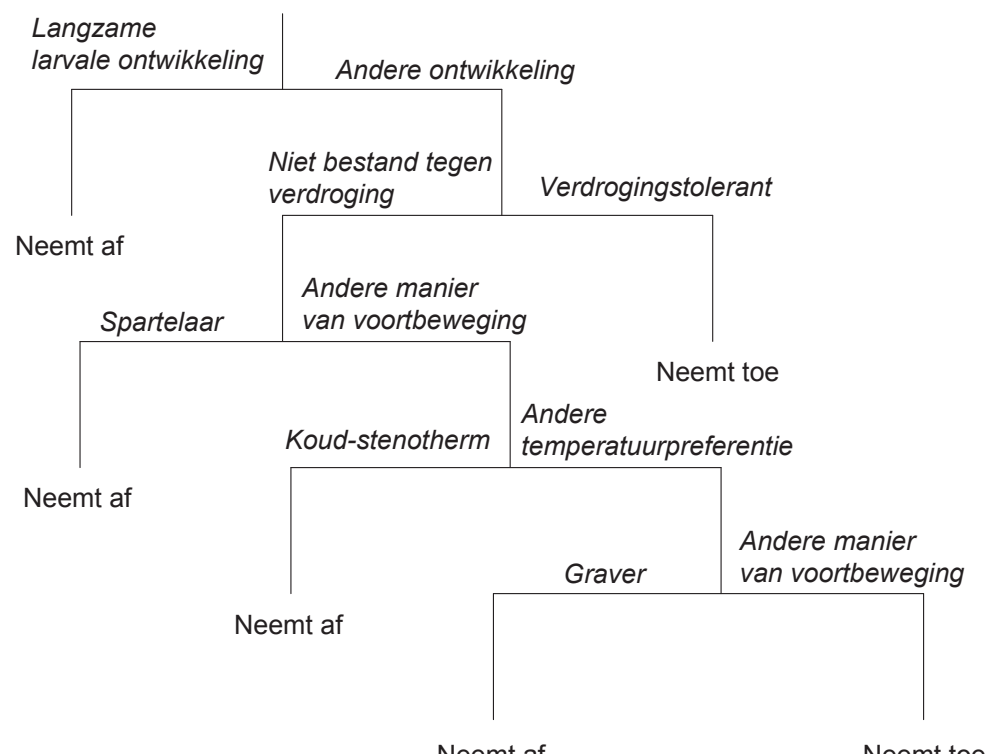

Neemt af

Neemt toe 


\section{MAATREGELPAKKETTEN EN SCENARIO'S}

\subsection{Inleiding}

Lange tijd is gewerkt met de vorm als uitgangspunt bij herstel: het patroonherstel. Beken werden hersteld door op plekken waar dat mogelijk was een meanderend traject aan te leggen. Sloten en watergangen werden 'verbeterd' door de oevers af te graven en natuurvriendelijk te maken. De verwachting was dat gewenste soorten zich er vervolgens zouden vestigen. Vaak bleven relevante processen in de waterlichamen echter buiten beeld en leidden deze herstelmaatregelen nauwelijks tot ecologische verbetering. De oorzaak hiervan was het niet in beschouwing nemen van alle direct relevante ecologische processen; in het geval van de nieuwe meander ondervindt deze nog altijd de invloed van het niet gewijzigde dynamische afvoerregime in de beek, net zoals de natuurvriendelijke oever die nog steeds onder invloed staat van eutrofiëring, het omgekeerde peilregime en het optreden van verslibbing.

Bovenstaande voorbeelden geven aan dat het steeds gaat om het herstellen van de gewenste bandbreedte van alle directe of ecologische sleutelfactoren die er voor het ecosysteem toe doen, al dan niet via het herstellen van de processen die de ecologische sleutelfactoren tot gevolg hebben. Daarbij komt dat procesherstel veelal goedkoper en duurzamer is dan patroonherstel. Immers kan een beek zelf haar loop vormen en langs een stilstaand water kan zich prima een oever-/ begeleidend moeras vormen. Het vraagt wel om een andere insteek bij het kiezen/nemen van maatregelen, omdat vooraf opgelegde maar niet passende ingrepen tot een ‘stand still' of falen kunnen leiden.

\subsection{Maatregeleffectiviteit}

Wanneer direct op de bron/oorzaak van menselijke activiteit kan worden ingegrepen, spreken we van een oorzaak- of brongerichte maatregel, zoals het direct ingrijpen op een landbouwkundige activiteit, bijvoorbeeld normering van de mestgift of het saneren van puntbronnen (o.a. Verdonschot et al. 2013). Wanneer tussen de bron en het effect, dus in de keten, wordt ingegrepen, spreken we van een effectgerichte maatregel (mitigatie), zoals het instellen van bufferzones tussen landbouwpercelen en het waterlichaam of het aanleggen van een waterberging om piekafvoeren te dempen. Wanneer geheel aan het einde van de keten in het waterlichaam wordt ingegrepen, met maatregelen zoals biomanipulatie of het toedienen van Phoslock, spreken we van end-of-pipe maatregelen.

Het belangrijkste bij het nemen van effectgerichte maatregelen is dat ze zoveel mogelijk verstoorde factoren in het waterecosysteem verbeteren. In het voorbeeld van de invloed van landbouwkundige activiteit in de vorige alinea zijn zowel de hydrologie, stoffen en de structuren door de activiteiten veranderd. Door in deze situatie een maatregel te nemen die alleen de hydrologie herstelt is de kans dat ecologisch herstel optreedt gering, omdat de nutriënten en eventueel andere stressoren, zoals toxische stoffen, ook moeten worden aangepakt om effect te sorteren. Daarom spreken we over het inzetten van maatregelpakketten in plaats van het nemen van individuele maatregelen.

Bij het kiezen van herstelmaatregelen speelt schaal een belangrijke rol. Generieke beleidsmaatregelen, zoals het inzetten van evenwichtsbemesting, heeft een veel groter ruimtelijk effect dan het aanleggen van een bufferzone langs een perceel. Zo hebben ruimtelijk grootschalige maatregelen in het stroomgebied ook veel meer effect dan lokale maatregelen. Bij het nemen van lokale maatregelen moet men erop bedacht zijn dat deze ook passen bij een grootschaliger, langere termijn doel. Maatregelen blijven dan ook in een groter geheel effectief. Dat geldt ook voor de tijdschaal; maatregelen die over een lange tijdsperiode of blijvend effect hebben zijn duurzaam. Het nemen van maatregelen met een ruimtelijk grootschalige uitwerking en die duurzaam blijven werken spelen in op de natuurlijke processen die horen bij het oorspronkelijke ecosysteem. Kortom, een lange-termijn-visie op de schaal van het hele stroomgebied, rekening houdend met toekomstige maatschappelijke ontwikkelingen, is noodzakelijk voordat herstelmaatregelen worden gekozen.

Om combinaties van maatregelen of maatregelpakketten samen te stellen is kennis nodig van de stressfactoren en de effecten op het waterecosysteem, m.a.w. de indirecte en directe factoren en de biologische respons. De relaties van stressfactoren met het waterecosysteem zijn in hoofdstuk 10 in de figuren $10.1-10.6$ gegeven. In de hierop passende maatre- 
gelenpakketten wordt de uitgebreide mechanistische kennis van de achterliggende processen wel gebruikt, maar is niet meer zichtbaar in de relatieschema's. De relaties worden uitgedrukt in aggregaties van processen op het bovenlokale/ regionale schaalniveau.

Systeemvoorwaarden zijn moeilijk stuurbaar en zijn sterk afhankelijk van grootschalige (vaak globale) maatregelen. Klimaatverandering leidt tot opwarming en veranderingen in de neerslag, met nattere winters en hevige zomerbuien naast droogte. Brongerichte maatregelen zijn het inzetten op verdergaand klimaatbeleid met passende wet- en regelgeving. Soms kunnen de effecten door klimaatverandering wel worden verminderd, bijvoorbeeld door een houtwal langs een beek die via beschaduwing het beekwater koelt, een inundatiezone langs een stromend of stilstaand water waar bij hevige neerslag water kan worden geborgen, of het verlagen van de nutriëntenbelasting om de eutrofiëring die door de opwarming wordt veroorzaakt te neutraliseren. Veel van deze effectgerichte maatregelen zijn werkzaam via de factoren stroming, structuren en stoffen.

In de figuren 11.1 tot en met 11.5 zijn enkele voorbeelden die aansluiten op de figuren 10.2 - 10.6 in hoofdstuk 10 via een selectie van relaties tussen menselijke activiteiten (agrarisch landgebruik, verstedelijking, industrie, bosbouw en soortmanipulatie) en stressfactoren, waaraan vervolgens de belangrijkste maatregelen gekoppeld zijn.

\section{FIGUUR 11.1}

Relatieschema agrarisch landgebruik - stressoren met voorbeeldmaatregelpakket landschapsbreed inrichten.

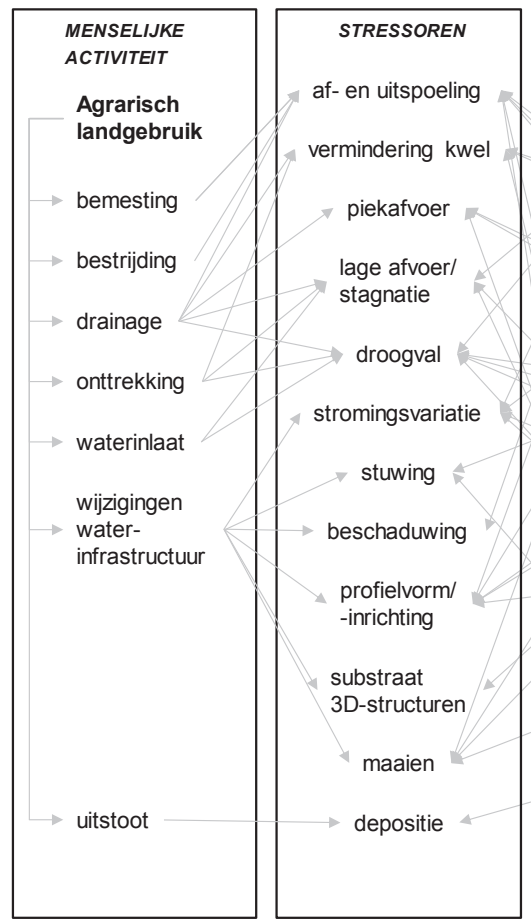

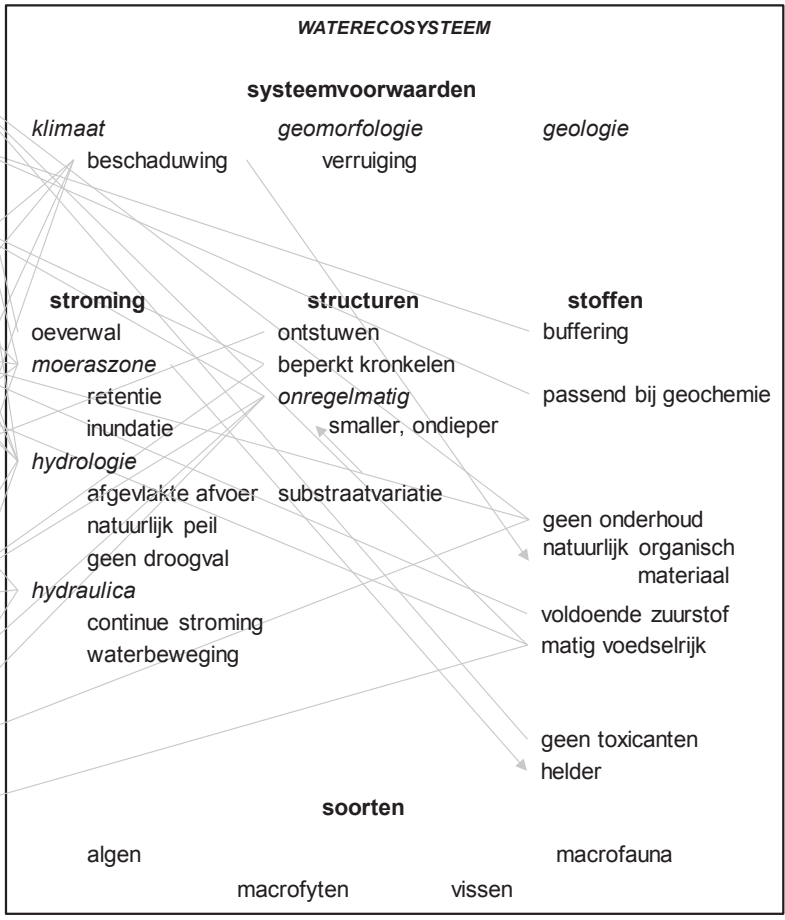


FIGUUR 11.2

Relatieschema urbaan landgebruik - stressoren met voorbeeldmaatregelpakket landschapsbreed inrichten.

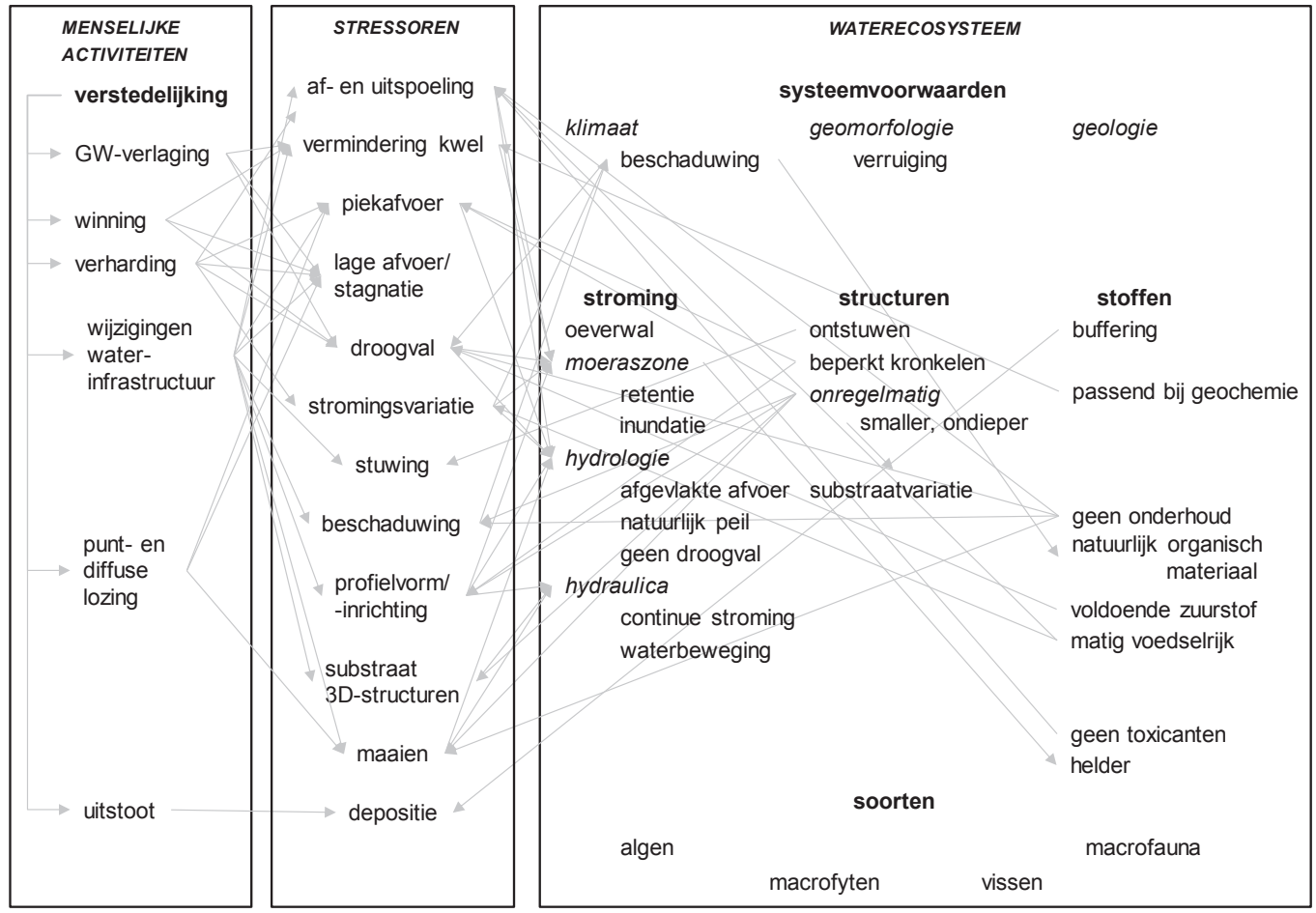

\section{FIGUUR 11.3}

Relatieschema industrie en energiewinning - stressoren met voorbeeldmaatregelpakket landschapsbreed inrichten.
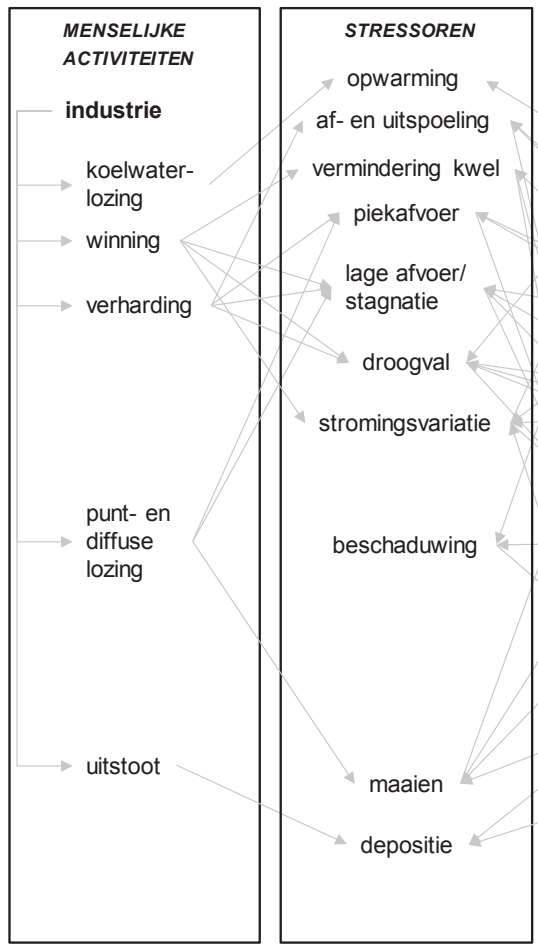

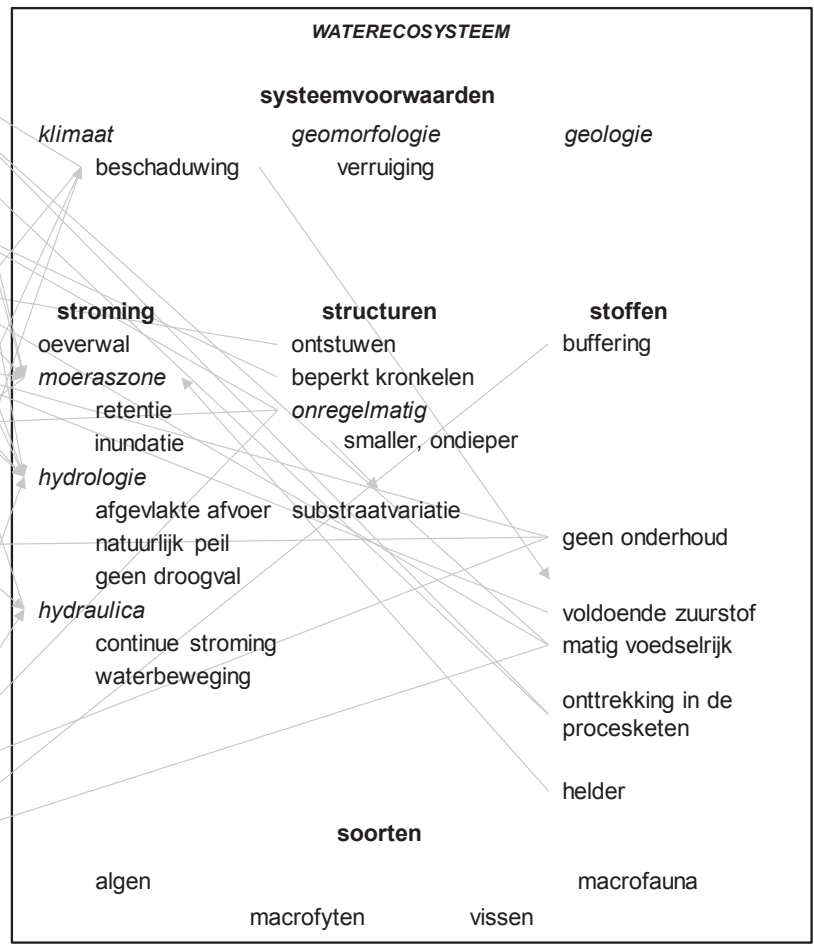


FIGUUR 11.4

Relatieschema bosbouw - stressoren met voorbeeldmaatregelpakket landschapsbreed inrichten.

$\longrightarrow$ verdroging

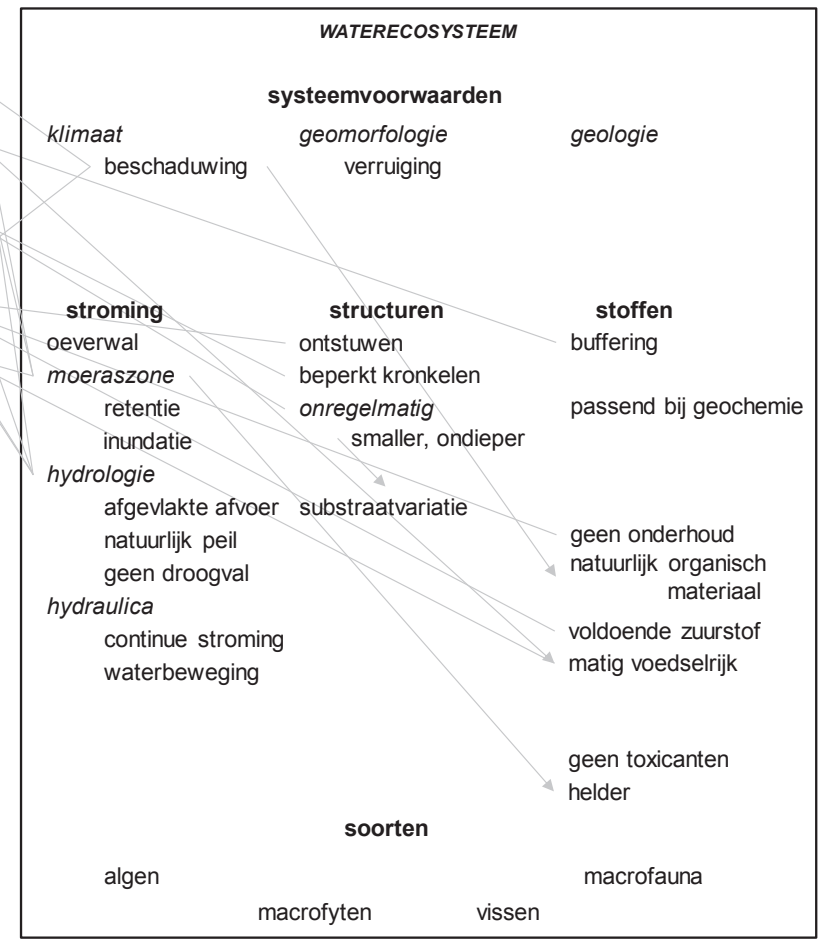

\section{FIGUUR 11.5}

Relatieschema soortenmanipulatie - stressoren met voorbeeldmaatregelpakket.

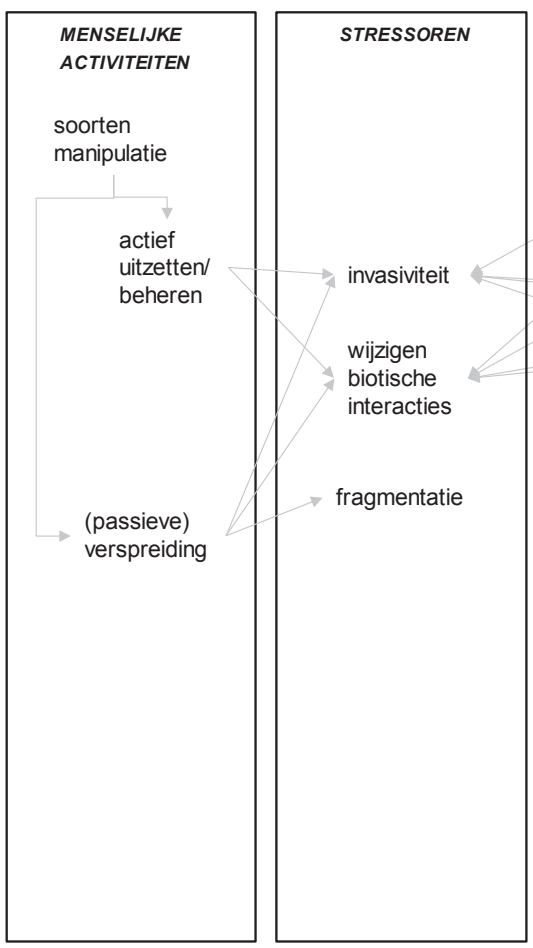

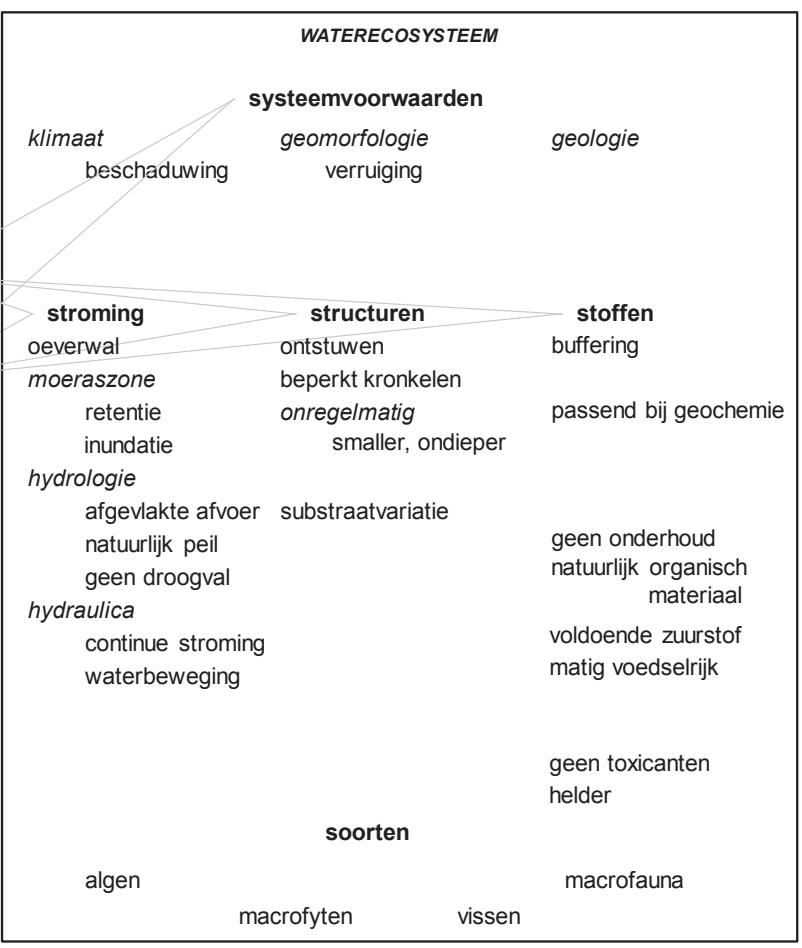


Om op lokale schaal effecten te zien van maatregelen is het van belang op basis van een ecologische systeemanalyse (SESA) de lokale knelpunten in beeld te krijgen. In Nederland zal altijd sprake zijn van een multiple stress situatie, wat betekent dat een maatregelpakket bijna altijd bestaat uit maatregelen t.a.v. stroming, structuren en stoffen, waar nodig aangevuld met maatregelen voor systeemvoorwaarden en soorten.

Op basis van een inventarisatie onder alle waterbeheerders is een lijst van maatregelen opgesteld (Tabel 11.1). De lijst is verdeeld naar hoofdwatertypen en naar operationeel schaalniveau. Uit deze lijst kunnen maatregelpakketten worden samengesteld die locatie of regio-specifiek zijn en aansluiten op de geïdentificeerde knelpunten. 


\section{TABEL 11.1}

Lijst met herstelmaatregelen, verdeeld naar hoofdwatertypen en het operationele schaalniveau ( $G=$ nationale en supraregionale schaal, $R=$ regionale schaal, $L=l o k a l e ~ s c h a a l)$.

\begin{tabular}{|c|c|c|c|c|c|c|c|c|}
\hline Hoofdfactor 5-S & Subfactor & Maatregel & 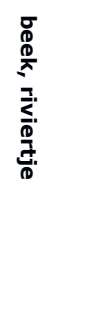 & 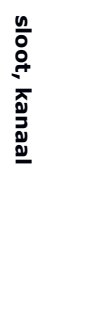 & 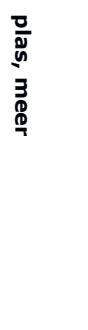 & 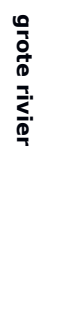 & 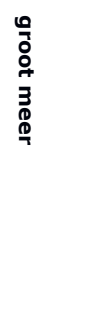 & 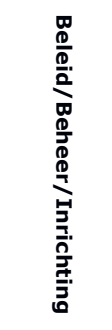 \\
\hline Systeemvoorwaarden & Generiek & Wijzigen /beperken gebruiksfunctie(s) & $G, R, L$ & $G, R, L$ & $G, R, L$ & $G, R, L$ & $G, R, L$ & Beleid \\
\hline Systeemvoorwaarden & Klimaat & Ontwikkelen houtige vegetatie/houtwal (verkoeling) & $\mathrm{D}$ & & & & & Inrichting \\
\hline Systeemvoorwaarden & Klimaat & Verkleinen windwerking & & & $\mathrm{R}, \mathrm{L}$ & & L & Inrichting \\
\hline Systeemvoorwaarden & Geohydrologie & Gedempt waterlichaam herstellen, overkluizing verwijderen & L & L & L & & & Inrichting \\
\hline Systeemvoorwaarden & Geohydrologie & Herstellen oorspronkelijk stroomgebied/waterlichaam (aankoppelen bovenloop/watergang) & $G, R$ & $\mathrm{R}$ & $\mathrm{R}$ & R & $\mathrm{R}$ & Inrichting \\
\hline Systeemvoorwaarden & Geomorfologie & Bodemopbouw en morfologie beschermen & $R, L$ & $R, L$ & $R, L$ & $R, L$ & $R, L$ & Beleid \\
\hline Systeemvoorwaarden & Geochemie & Herstellen/sturen op kwelstromen & $G, R$ & $G, R$ & $G, R$ & R & R & Inrichting \\
\hline Stroming & Grondwater & Bevorderen infiltratie regenwater & $G, R$ & $G, R$ & $G, R$ & & & Inrichting \\
\hline Stroming & Grondwater & Verminderen verdamping/Ontwikkelen loofbos & $G, R$ & $G, R$ & $G, R$ & & & Inrichting \\
\hline Stroming & Grondwater & Verhogen grondwaterpeil & $G, R$ & $G, R$ & $G, R$ & & & Inrichting \\
\hline Stroming & Grondwater & Verwijderen/verminderen (open of gesloten) drainage/dempen sprengen & $G, R, L$ & $G, R$ & $G, R$ & & & Inrichting \\
\hline Stroming & Grondwater & Verminderen / verplaatsen van de grondwaterwinning & $\mathrm{R}$ & $\mathrm{R}$ & $\mathrm{R}$ & & & Inrichting \\
\hline Stroming & Grondwater & Verminderen grondwateronttrekking industrieel, landbouw, particulier & $R, L$ & $\mathrm{R}, \mathrm{L}$ & $\mathrm{R}, \mathrm{L}$ & & & Beheer \\
\hline Stroming & Grondwater/Hydrologie & Vasthouden water in haarvaten (gebiedseigen) & $R, L$ & $R, L$ & $R, L$ & & & Inrichting \\
\hline Stroming & Grondwater/Hydrologie & Ontwikkelen inundatiezone (natte milieus) & $R, L$ & $R, L$ & $\mathrm{R}, \mathrm{L}$ & $R, L$ & $R, L$ & Inrichting \\
\hline Stroming & Grondwater/Hydrologie & Vergroten retentie (retentiebekken, bergingsgebied, bergingscapaciteit) & $R, L$ & $R, L$ & $\mathrm{R}, \mathrm{L}$ & $R, L$ & $R, L$ & Inrichting \\
\hline Stroming & Grondwater/Hydrologie & Hergebruiken gezuiverd effluent & L & L & L & & & Beheer \\
\hline Stroming & Hydrologie & Verdiepen watergang/-systeem (overdimensioneren) & & L & L & & L & Inrichting \\
\hline Stroming & Hydrologie & Oorspronkelijke hydrologie herstellen & $G, R$ & $G, R$ & $G, R$ & & & Inrichting \\
\hline Stroming & Hydrologie & Aanleggen hydrologische buffer(zone) & $R, L$ & $R, L$ & $R, L$ & & & Inrichting \\
\hline Stroming & Hydrologie & Verminderen oppervlaktewateronttrekking & $R, L$ & $R, L$ & $R, L$ & & & Beheer \\
\hline
\end{tabular}




\begin{tabular}{|c|c|c|c|c|c|c|c|c|}
\hline Stroming/Stoffen & Hydrologie/Macro-ionen & Sturen op wateraanvoer/-inlaat en of afvoer/Scheiden waterstromen & $\mathrm{R}$ & $\mathrm{R}$ & $\mathrm{R}$ & & & Beheer \\
\hline Stroming & Hydrologie & Aanleggen nevengeul(en) & L & & & L & & Inrichting \\
\hline Stroming/Soorten & Hydrologie & Aanleggen sloten, poelen, veenplassen & $\mathrm{L}$ & L & $\mathrm{L}$ & L & & Inrichting \\
\hline Stroming & Hydrologie & Reguleren/optimaliseren peil (natuurlijk, flexibel) & $G, R$ & $G, R$ & $G, R$ & & G & Beheer \\
\hline Stroming & Hydrologie & Afleiden piekafvoeren & $R, L$ & & & & & Inrichting \\
\hline Stroming & Hydrologie & Hydrologisch isoleren & & $R, L$ & $R, L$ & & & Inrichting \\
\hline Stroming/Structuren & Hydraulica/Oeverzone & Vergroten stromingsvariatie & $\mathrm{L}$ & & & L & & Inrichting \\
\hline Stroming/Structuren & Hydraulica/Oeverzone & Beperken oevererosie, golfslag & & & $\mathrm{L}$ & & $R, L$ & Inrichting \\
\hline Structuren & Oeverzone & Aanleggen beekbegeleidende zone/moeras & $R, L$ & & & & & Inrichting \\
\hline Structuren & Oeverzone & Inrichten oever/Ontwikkelen oevervegetatie, uiterwaard & & $R, L$ & $R, L$ & $R, L$ & $R, L$ & Beheer \\
\hline Structuren & Lengteprofiel & Passief ontwikkelen meanders (kronkels)/Verlengen lengteprofiel & $R, L$ & & & & & Beheer \\
\hline Structuren & Lengteprofiel & Graven/aankoppelen meanders (kronkels) & $R, L$ & & & & & Beheer \\
\hline Structuren & Lengte-/Dwarsprofiel & Actief/passief ontwikkelen micromeanders & $R, L$ & & & & & Inrichting \\
\hline Structuren & Lengte-/Dwarsprofiel & Aanpassen/Differentiëren/Achterwege laten maaibeheer & $R, L$ & $R, L$ & $R, L$ & & $R, L$ & Beheer \\
\hline Structuren & Lengte-/Dwarsprofiel & Uitdiepen/opschonen sprengen & L & & & & & Beheer \\
\hline Structuren & Lengte-/Dwarsprofiel & Sedimentatie bevorderen & $R, L$ & & & $R, L$ & & Beheer \\
\hline Structuren & Dwarsprofiel & Verkleinen doorstroomprofiel/Suppleren zand & $R, L$ & & & & & Inrichting \\
\hline Structuren & Dwarsprofiel & Verwijderen/vervangen profielverdediging/beschoeiing & L & L & L & L & L & Inrichting \\
\hline Structuren & Dwarsprofiel & Aanleggen accoladeprofiel/twee-fasen bedding & $R, L$ & & & & & Inrichting \\
\hline Structuren & Dwarsprofiel & Aanleggen asymmetrisch/natuurlijk profiel (steil, overhangend, flauw) & $R, L$ & $R, L$ & & & & Inrichting \\
\hline Structuren & Dwarsprofiel & Aanleggen cascade & L & & & & & Inrichting \\
\hline Structuren & Dwarsprofiel & Scheiden zand- en slibvang & L & & & & & Beheer \\
\hline Structuren & Dwarsprofiel/Substraat & Ontwikkelen pool-riffle systeem/stroomkuilen en zandbanken & L & & & & & Inrichting \\
\hline
\end{tabular}




\begin{tabular}{|c|c|c|c|c|c|c|c|c|}
\hline Structuren & Oeverprofiel & Stimuleren verlanding & & $R, L$ & $R, L$ & & $R, L$ & Beheer \\
\hline Structuren & Oeverprofiel & Tegengaan verlanding & & $R, L$ & $\mathrm{R}, \mathrm{L}$ & & & Beheer \\
\hline Structuren & Oeverprofiel & Terugzetten verlanding & & $R, L$ & $R, L$ & & & Inrichting \\
\hline Structuren & Oeverprofiel & Aanleggen flauwe oevertaluds & $R, L$ & $R, L$ & $\mathrm{R}, \mathrm{L}$ & & $R, L$ & Inrichting \\
\hline Structuren & Oeverprofiel & Aanleggen natuurvriendelijk slootprofiel/Creëren gevarieerd profiel/Aanleggen natuurvriendelijke oever (NVO) & & $R, L$ & $\mathrm{R}, \mathrm{L}$ & & $R, L$ & Inrichting \\
\hline Structuren & $\begin{array}{l}\text { Oeverprofiel } \\
\text { Oeverprofiel/Substraat// }\end{array}$ & Verondiepen watergang/-lichaam & $R, L$ & $R, L$ & $R, L$ & & $R, L$ & Inrichting \\
\hline Structuren/Stoffen & $\begin{array}{l}\text { Nutriënten/Gifstoffen) } \\
\text { Nutrent/ }\end{array}$ & Verminderen/Stoppen/Optimaliseren baggeren & & $R, L$ & $R, L$ & & & Beheer \\
\hline Structuren & Oeverprofiel/Substraat & Aanleggen luwtegebieden/Recreatie reguleren & & $\mathrm{L}$ & L & & L & Beheer \\
\hline Structuren/Soorten & Substraat & Verbeteren substraatvariatie/Vergroten habitatheterogeniteit/Aanbrengen (stoor)objecten & $\mathrm{L}$ & L & L & & & Inrichting \\
\hline Structuren & Substraat & Tegengaan vertroebeling (slib) bv. door afspoelingsreductie & & $\mathrm{R}$ & $\mathrm{R}$ & & $\mathrm{R}$ & Beheer \\
\hline Structuren & Connectiviteit & Verbinding/connectiviteit verbeteren & $\mathrm{L}$ & L & $\mathrm{L}$ & L & & Inrichting \\
\hline Structuren & Connectiviteit & Vrije doorstroming creëren/Verwijderen stuwen/Duiker vergroten/verwijderen & $\mathrm{L}$ & L & L & & & Inrichting \\
\hline Stoffen & Zuurstof & Verbeteren zuurstofhuishouding/Beluchten waterlichaam & $\mathrm{L}$ & & & & & Beheer \\
\hline Stoffen & Macro-ionen & Aanbrengen/Verbinden zoet-zout gradiënt & & L & & $\mathrm{L}$ & L & Inrichting \\
\hline Stoffen & Zuurgraad & Tegengaan verzuring door beleidsmaatregelen & & & $\mathrm{L}$ & & & Beleid \\
\hline Stoffen & Nutriënten & Doorspoelen & & $R, L$ & $R, L$ & & $\mathrm{R}$ & Beheer \\
\hline Stoffen & Nutriënten & Fixeren fosfaat & & & L & & & Beheer \\
\hline Stoffen & Nutriënten & Tegengaan $\mathrm{N}$-depositie & $\mathrm{G}, \mathrm{R}$ & $G, R$ & $G, R$ & & G & Beleid \\
\hline Stoffen & Nutriënten & Verlagen maaiveld/Verschralen/plaggen oever(zones/landen) & L & $\mathrm{L}$ & L & & & Inrichting \\
\hline Stoffen & Nutriënten & Verlengen waterweg & & $R, L$ & & & & Inrichting \\
\hline Stoffen & Nutriënten/Gifstoffen & Voorkomen (versnelde) afstroming/runoff & $R, L$ & $R, L$ & $R, L$ & & & Inrichting \\
\hline Stoffen & Nutriënten/Gifstoffen & Saneren waterbodem/oever & $R, L$ & $R, L$ & $R, L$ & & & Inrichting \\
\hline Stoffen & Nutriënten/Organisch materiaal & Ontwikkelen (geleidelijke) droog-nat gradiënten/litorale zone-moeras & $\mathrm{R}, \mathrm{L}$ & $R, L$ & $R, L$ & $R, L$ & $R, L$ & Inrichting \\
\hline
\end{tabular}




\begin{tabular}{|c|c|c|c|c|c|c|c|c|}
\hline Stoffen & Organisch materiaal & Tegengaan bijvoeren dieren & & & $\mathrm{L}$ & & & Beheer \\
\hline Stoffen & Organisch materiaal & Tegengaan guanotrofie & & & $\mathrm{L}$ & & & Beheer \\
\hline Stoffen & Organisch materiaal & Tegengaan/terugdringen saprobiëring door saneren RWZI, overstorten, lozingen & $R, L$ & $\mathrm{R}, \mathrm{L}$ & $R, L$ & & & Beleid \\
\hline Stoffen & $\begin{array}{l}\text { Nutriënten//Organisch } \\
\text { materiaal/Gifstoffen } \\
\text { Nutriënten/Organisch }\end{array}$ & Aanleggen bufferzone/Mest-/Spuitvrije zone aanleggen & $R, L$ & $R, L$ & $\mathrm{R}, \mathrm{L}$ & & & Inrichting \\
\hline Stoffen & $\begin{array}{l}\text { materiaal/Gifstoffen } \\
\text { Nutriënten/Organisch }\end{array}$ & Aanleggen zuiveringsmoerassen/helofytenfilters & $R, L$ & $R, L$ & $\mathrm{R}, \mathrm{L}$ & & & Inrichting \\
\hline Stoffen & $\begin{array}{l}\text { materiaal/Gifstoffen } \\
\text { Nutriënten/Organisch }\end{array}$ & Stoppen/Verminderen meststoffentoevoer landbouw dor regelgeving en recirculatie & $G, R$ & $G, R$ & $\mathrm{G}, \mathrm{R}$ & & & Beleid \\
\hline Stoffen & $\begin{array}{l}\text { materiaal/Gifstoffen } \\
\text { Nutriënten/Organisch }\end{array}$ & Verbeteren/saneren/opheffen belasting met RWZI effluent & $\mathrm{L}$ & $\mathrm{L}$ & $\mathrm{L}$ & & & Inrichting \\
\hline Stoffen & $\begin{array}{l}\text { materiaal/Gifstoffen } \\
\text { Nutriënten/Organisch }\end{array}$ & & $\mathrm{L}$ & $\mathrm{L}$ & $\mathrm{L}$ & $\mathrm{L}$ & $\mathrm{L}$ & Inrichting \\
\hline Stoffen & $\begin{array}{l}\text { materiaal/Gifstoffen } \\
\text { Nutriënten/Organisch }\end{array}$ & Opherfen/saneren hulshoudeiljke en ongezuiverde lozingen & $\mathrm{L}$ & $\mathrm{L}$ & $\mathrm{L}$ & & & Inrichting \\
\hline Stoffen & $\begin{array}{l}\text { materiaal/Gifstoffen } \\
\text { Nutriënten/Organisch }\end{array}$ & Upherren/verbeteren overstorten & $\mathrm{L}$ & $\mathrm{L}$ & $\mathrm{L}$ & & & Inrichting \\
\hline Stoffen & $\begin{array}{l}\text { materiaal/Gifstoffen } \\
\text { Nutriënten/Organisch }\end{array}$ & Herstellen lekke riolen & $\mathrm{L}$ & $\mathrm{L}$ & $\mathrm{L}$ & & & Inrichting \\
\hline Stoffen & materiaal/Gifstoffen/Macro-ionen & Saneren/Stoppen/verminderen industriële lozingen & $\mathrm{L}$ & $\mathrm{L}$ & $\mathrm{L}$ & & & Inrichting \\
\hline Stoffen & Gifstoffen & Stoppen/Verminderen toevoer toxische stoffen landbouw, stad, verkeer & $R, L$ & $R, L$ & $R, L$ & & & Inrichting \\
\hline Stoffen & Gifstoffen & Stoppen/Verminderen toevoer toxische stoffen verkeer & $R, L$ & $R, L$ & $\mathrm{R}, \mathrm{L}$ & & & Inrichting \\
\hline Stoffen & Gifstoffen & Stoppen/Verminderen toevoer toxische stoffen bouwmaterialen & $\mathrm{L}$ & $\mathrm{L}$ & $\mathrm{L}$ & & & Inrichting \\
\hline Soorten & $\begin{array}{l}\text { (Semi)terrestrische planten en } \\
\text { dieren }\end{array}$ & Oever natuurvriendelijk beheren & $R, L$ & $R, L$ & $\mathrm{R}, \mathrm{L}$ & $R, L$ & $\mathrm{R}, \mathrm{L}$ & Beheer \\
\hline Soorten & Terrestrische fauna & Aanpassingen aanbrengen voor terrestrische fauna & $\mathrm{L}$ & $\mathrm{L}$ & $\mathrm{L}$ & $\mathrm{L}$ & $\mathrm{L}$ & Inrichting \\
\hline Soorten & Vegetatie & Beheren met begrazers (oever/dal) & $\mathrm{L}$ & & $\mathrm{L}$ & $\mathrm{L}$ & L & Beheer \\
\hline Soorten & Macrofyten & Uitvoeren actief vegetatiebeheer (enten, zaaien, planten) & $\mathrm{L}$ & $\mathrm{L}$ & $\mathrm{L}$ & $\mathrm{L}$ & $\mathrm{L}$ & Beheer \\
\hline Soorten & Macrofyten/Macrofauna/Vissen & Herintroduceren/Uitzetten soorten & $\mathrm{L}$ & $\mathrm{L}$ & $\mathrm{L}$ & $\mathrm{L}$ & $\mathrm{L}$ & Beheer \\
\hline Soorten & Macrofyten/Vissen & Uitvoeren soortspecifieke maatregelen/Aanleggen groei-/leef- (paai)gebieden & $\mathrm{L}$ & $\mathrm{L}$ & $\mathrm{L}$ & $\mathrm{L}$ & $\mathrm{L}$ & Inrichting \\
\hline Soorten & Vissen & Uitvoeren actief visstands- of schelpdierstandsbeheer & $\mathrm{L}$ & $\mathrm{L}$ & $\mathrm{L}$ & L & L & Beheer \\
\hline Soorten & Vissen & Uitvoeren actief biologisch beheer & & & $\mathrm{L}$ & & & Beheer \\
\hline Soorten & Vissen & Aanleggen vispassage & $\mathrm{L}$ & $\mathrm{L}$ & $\mathrm{L}$ & $\mathrm{L}$ & $\mathrm{L}$ & Inrichting \\
\hline
\end{tabular}




\section{DEEL IV HANDELINGSPERSPECTIEF VOOR EEN SESA LAAGLANDBEEK}

$\rightarrow$ 


\section{INLEIDING}

\subsection{Inleiding}

Voor de stroomgebieden van laaglandbeken is praktische uitwerking van de Stroomgebiedsbrede Ecologische Systeemanalyse methodiek (SESA) opgesteld. Deze uitwerking berust op de ervaringen opgedaan met (en in opdracht van) het Waterschap Limburg (WL) met het ontwikkelen en uitvoeren van SESAs voor de Tungelroyse beek en de Groote Molenbeek. De aanleiding voor het ontwikkelen van de SESA was dat WL behoefte had aan concrete, haalbare en betaalbare ontwikkelingsbeelden (realistische streefbeelden in termen van maatregelpakketten en ecologische effecten), die binnen een termijn van circa 15 jaar gerealiseerd moeten kunnen worden.

In dit deel is stapsgewijs de methode omschreven die wordt gevolgd bij het uitvoeren van een SESA voor een stroomgebied van een laaglandbeek. Hierbij zijn de stappen van de abiotische en biotische cyclus doorlopen. Het omvat een analyse van de oorspronkelijke situatie (die helpt bij het vormen van een beeld van de doelsituatie op lange termijn en het natuurlijke systeem functioneren), de huidige toestand (de aanwezige stressoren en biologie) en de daaruit volgende realistische streefbeelden voor de nabije toekomst.

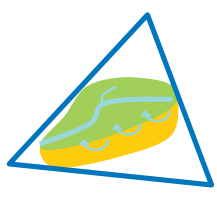

Geohydrologie

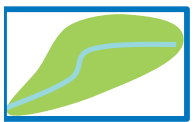

Hydrologie

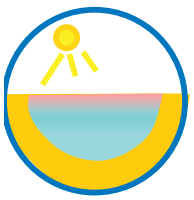

Fysisch

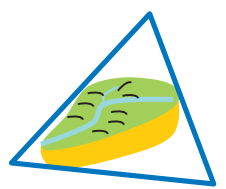

Geomorfologie

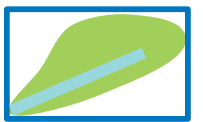

Morfologie

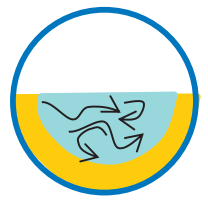

Hydraulisch

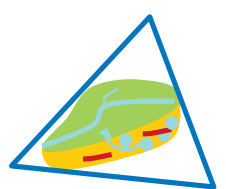

Geochemie

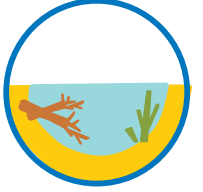

Morfologisch

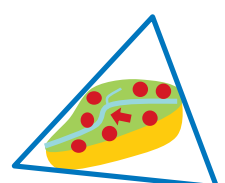

Diffuse bronnen

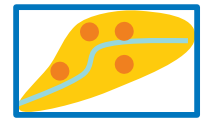

Diffuse bronnen

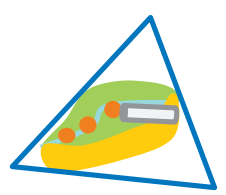

Puntbronnen

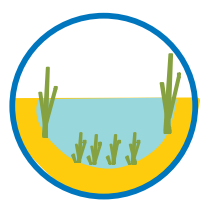

Beheer en onderhoud 


\section{HET MACROSYSTEEM}

\subsection{Afbakenen en indelen van het onderzoeksgebied}

Een SESA start met het geografisch afbakenen en het indelen van het te analyseren stroomgebied. De stappen omvatten:

1. Het begrenzen van het stroomgebied.

2. Het aanwijzen van het te analyseren waterlichaam (of meerdere).

3. Het opdelen van het stroomgebied in afwaterings- en zijstroomgebieden.

4. Het vaststellen van de beekdalbufferzones (naar hoogtelijnen/oorspronkelijk beekdal of een breedtezone van een bepaalde (flexibele) breedte).

5. Het indelen van de beek in segmenten.

De opdeling van het complete stroomgebied in afwaterings- en zijstroomgebieden (vlakken) en de beek in segmenten is nodig om later een berekening te kunnen maken van de daarin aanwezige stressoren en mate van stress. Deze opdeling is uiterst belangrijk, omdat de in de volgende stappen te verzamelen data hierop worden toegesneden. De opdelingen worden zo gekozen dat de uiteindelijke uitkomst van de analyse bruikbaar is voor het opstellen van realistische streefbeelden en het kiezen van uitvoerbare maatregelen. Een minimale resolutie is nodig om de variatie en diversiteit in een landschap te omvatten. Tegelijkertijd zal uiteindelijk niet elk beeksegment eigen streefbeeld krijgen, omdat vaak onvoldoende lokale data beschikbaar zijn en aaneengesloten segmenten met dezelfde of vergelijkbare kenmerken geaggregeerd kunnen worden, die daarna trajecten gaan heten.

\subsection{Abiotische referentie}

Allereerst worden op hoofdlijnen de milieu- of systeemrandvoorwaarden in het stroomgebied vastgesteld. Deze randvoorwaarden zijn richtinggevend voor de mogelijkheden (ze reflecteren een mogelijk doel op lange termijn of punt aan de horizon). Binnen deze richting wordt, met in achtneming van onomkeerbare veranderingen en ontwikkelingen in de nabije toekomst, later het ecologische doel op kortere termijn geformuleerd.

Door antwoord te geven op onderstaande vragen worden de systeemvoorwaarden ingevuld:

1. Wat zijn de ecologisch relevante randvoorwaarden die volgen uit klimaat, geohydrologie, geomorfologie en geochemie van het te onderzoeken stroomgebied en wat is de samenhang op stroomgebiedsschaal?

2. Hoe zag het oorspronkelijk ecologisch functioneren op stroomgebiedsschaal eruit en wat is daarvan niet onomkeerbaar veranderd (bijvoorbeeld bij het afgraven van hoogveen is dat deel van de oorspronkelijke situatie onomkeerbaar veranderd en speelt dus geen rol meer in de toekomst) en nog relevant voor de toekomst?

3. Welke beek- en beekdaltypen waren aanwezig en hoe kan dit invloed hebben op toekomstige keuzes van doelen?

4. Hoe zag de trajectindeling eruit op basis van het oorspronkelijk (reversibel deel van het) functioneren?

5. Welke ontwikkelingen zijn er in de nabije toekomst te verwachten die inwerken op de systeemvoorwaarden (bijvoorbeeld klimaatverandering)?

Het vaststellen van de vorm van het beekdal en de ligging van natte gebieden (moerassen, vennen) zijn bij het beschrijven van het oorspronkelijk functioneren van het grootste belang. Deze gebiedsdelen zijn tegenwoordig vaak minder zichtbaar of verdwenen maar komen in deze stap wel in beeld. Tijdens de analyse wordt de afweging gemaakt of deelgebieden in toekomst weer op de oorspronkelijke wijze kunnen gaan functioneren of dat inmiddels een onomkeerbare verandering in het landschap en de systeemvoorwaarden van de toekomst dit onmogelijk maken (bijvoorbeeld als een dorp op de voorheen natte plek is gebouwd). Deze stap geeft inzicht in potenties en beperkingen van doelen en maatregelen.

De systeemvoorwaarden geven een globaal beeld van het functioneren van het stroomgebied op hoog schaalniveau in ruimte en tijd. We noemen dit ook wel het macrosysteem. Het macrosysteem wordt beschreven op basis van:

Klimaat: Neerslag en temperatuur zijn belangrijke systeemvoorwaarden.

2. Geologie: De geologische kaart geeft inzicht in de diepere bodemlagen i.v.m. grondwaterstromen en -samenstelling.

Geohydrologie: de geohydrologische informatie geeft inzicht in ondiepe en diepe grondwaterstromen. 
4. Geomorfologie: De geomorfologische kaart geeft inzicht in de hoogteverschillen in het landschap en daarmee de oorspronkelijke ligging en vorm (breedte) van het beekdal en daarmee de mogelijke locaties met doorstroom- en beekmoerassen. Dit helpt om de beekloop, waar mogelijk, weer terug te leggen in de laagste delen van het stroomgebied.

5. Hoogtelijnen kaart AHN: De AHN is vooral van belang voor het bepalen van het potentiële verhang van de beek en de ligging en vorm (breedte) van het beekdal, m.a.w. de vorm van de beekdalbufferzone.

6. Geochemie: De geochemische situatie geeft een indicatie voor de potentie van de aanwezigheid van kalkrijke kwel, een belangrijke voorwaarde voor het voorkomen van kwelindicatoren in de beekbegeleidende zone.

7. Bodem: De bodemkaart duidt bijvoorbeeld aan waar in het verleden beekveenvorming heeft plaatsgevonden en dus waar het nat was en bleef.

8. Oude landschapskaarten. Deze oude kaarten kunnen helpen bij het reconstrueren van het oorspronkelijkere beekdal en geven inzicht in het vroegere (niet oorspronkelijke) landschap.

Het macrosysteem is richtinggevend en wordt beschouwd als drager van het functioneren van het toekomstige watersysteem. Maatregelen die inspelen op de natuurlijke situatie en processen in het macrosysteem leveren het meest robuuste watersysteem op (denk aan het bouwen-met-natuur principe).

Grondwater-oppervlaktewatermodellen kunnen de geohydrologie sterk ondersteunen. Door alle menselijke ingrepen weg te nemen en het model de 'natuurlijke' situatie te laten doorrekenen kan in een stroomgebied inzicht worden verkregen in de natuurlijke afvoer, de natuurlijke grondwaterstromen en de plaatsen met sterke kwel.

\subsection{Biologische referentie}

De biologische referentie bestaat uit een globale biologische beschrijving van het beeksysteem op stroomgebiedsniveau, niet per segment of traject. Er zijn in het verleden uitgebreide beschrijvingen van referentietypen opgesteld die voor deze beschrijving bruikbaar zijn, zoals:

- Beeksystemen in de provincie Limburg (Verdonschot \& Nijboer 2000).

- Beken van Vallei \& Veluwe (Verdonschot et al. 1999, Jaarsma et al. 2001).

- Wateren in Gelderland (Provincie Gelderland 1995).

Wateren in Overijssel (Verdonschot 1990, Sinkeldam et al. 1998).

- Nederlandse beken (Verdonschot \& Nijboer 2004).

- Nederlandse sloten (Nijboer et al. 2003).

- Duinwateren (Janssen et al. 1998).

- Wateren in het rivierengebied (Nijboer \& Verdonschot 1997).

- Moerasbeken en doorstroommoerassen (Verdonschot et al. 2016).

- Wateren in Flevoland (Verdonschot \& Jaarsma 2000).

Daarnaast zijn landelijk referenties beschreven als onderdeel van de Natuurdoeltypen:

Bronnen (Verdonschot 2000).

Beken (Verdonschot 2000).

Wateren in het rivierengebied (Nijboer et al. 2000).

Brakke binnenwateren (Beers van \& Verdonschot 2000).

Poelen (Jaarsma \& Verdonschot 2000).

Sloten (Nijboer 2000).

Laagveenwateren (Higler 2000).

Wingaten (Jaarsma \& Verdonschot 2000).

Rijksmeren (Molen van der 2000).

10 Regionale kanalen (Jaarsma \& Verdonschot 2000).

1 Rijkskanalen (Aarts 2001).

12 Zoete duinwateren (Verdonschot \& Jansen 2000).

13 Vennen (Arts 2000). 
Ook is er een overzicht beschikbaar van (anekdotisch) historisch materiaal met beschrijvingen van de macrofauna, macrofyten en vissen in sloten en beken, ontsloten uit verschillende archieven van Staatsbosbeheer, het voormalige Instituut voor Bos- en Natuuronderzoek, de bibliotheek van Alterra en privécollecties van hydrobiologische deskundigen. 


\section{DE STRESSOREN}

\subsection{Het selecteren van stressoren}

Informatie over stressoren is te vinden in Deel II, hoofdstuk 6. Voor de selectie van stressoren wordt gebruik gemaakt van de indeling van factoren naar het 5S-Model (Verdonschot et al. 1998). De stressoren zijn ge-ent op relaties met de ecologische sleutelfactoren uit het 5S-model en opgedeeld naar relevante schaal in ruimte en tijd.

Voor de geografische (ruimtelijke) schaal worden vier niveaus onderscheiden:

- Stroomgebied

- Afwaterings- en zijstroomgebied

- Beekdalbufferzone

- Natuurbeek (Waterlichaam)

Voor de classificatie van stressoren worden de volgende hoofdgroepen onderscheiden:

- Geografie

- Systeemvoorwaarden

- Hydrologie

- Morfologie

- Chemie

- Biologie

Als tijdschaal wordt een periode van circa 10-20 jaar gehanteerd.

De selectie van stressoren (Tabel 14.1) geeft een beeld van die factoren die voor de doelgemeenschappen binnen een bepaalde range als stressoren kunnen worden ervaren. Hierbij wordt erop gelet dat er geen overlappende stressoren worden meegenomen, aangezien dit zou leiden tot een overwaardering van de stress. Stressoren die niet zijn meegenomen vanwege deze (gedeeltelijke) overlap zijn bijvoorbeeld puntmetingen voor chemie in oppervlaktewater en bodem, omdat die al opgenomen zijn als punt- en diffuse bronnen.

\subsection{Het invullen van stressorklassen}

De mate van stress van iedere stressor, m.a.w. het negatieve effect op de aquatische ecologie, is gestandaardiseerd naar vijf klassen. Idealiter is de classificatie van stress een watertype-specifieke standaardisatie, daar het watertype bepaalt in welke mate een stressor invloed heeft op de doelgemeenschap. Deze watertype gebonden specificatie wordt vervat in het toekennen van gewichten per watertype.

Voor de invulling van de stressklassen kan bijvoorbeeld de abiotische classificering achter de WEW-preferentielijst (Verberk et al. 2012) worden gebruikt, waarbij de stressklassen gebaseerd worden op de respons (vaak over langere termijn) van de biota. Een combinatie van de preferenties van de doelgemeenschap geeft een range van geprefereerde aanwezige omgevingsfactoren. Aan afwijkende ranges van de omgevingsfactoren kunnen stressorklassen worden toegewezen. Ook kan gebruik worden gemaakt van reeds gepubliceerde stress-classificeringen, zoals de grenzen in het boek 'Waterplanten en waterkwaliteit' (Bloemendaal \& Roelofs 1988) en de grenzen benoemd in het 'EKOO' boek (Verdonschot 1990).

Specifieke studies gebaseerd op gemeenschappen, zoals de cenotypologie voor Limburg, en publicaties over biologische responsen op bijvoorbeeld extremen, zoals piekafvoeren, geven extra inzicht in de preferenties van soorten en gemeenschappen in verschillende watertypen en daarmee indicaties van de ranges van milieufactoren waaronder stress voor een bepaalde soort of gemeenschap optreedt. Ook dit draagt bij aan het vaststellen van klassengrenzen.

Voor de stressoren zijn ranges van stressklassen gedefinieerd op een schaal van 0 (= geen stress) tot -5 (= veel stress). In sommige gevallen oefent een stressor positieve invloed uit; in dat geval wordt een positieve score toegekend. 


\section{TABEL 14.1}

Overzicht van geografische eenheid, hoofdtype stress en stressor(groep)en. GIS staat voor GIS gebaseerde informatie over landgebruik, die is 'vertaald' naar stress. De term 'Waterschapsbestand' refereert naar (vaak) bij waterschappen aanwezige informatie.

\begin{tabular}{|c|c|c|c|}
\hline $\begin{array}{l}\text { Geografische } \\
\text { eenheid }\end{array}$ & Hoofdtype stress & Stressor(groep) & Mogelijke informatiebron \\
\hline \multirow{4}{*}{$\begin{array}{l}\text { Afwaterings-', } \\
\text { zijstroomgebied, } \\
\text { beekdalbufferzone }\end{array}$} & $\begin{array}{l}\text { Hydrologische } \\
\text { stress }\end{array}$ & Afspoeling (runoff) & Hydrologisch model \\
\hline & & Uitspoeling (drainage) & Hydrologisch model \\
\hline & & $\begin{array}{l}\text { Uitspoeling (flux naar } \\
\text { de waterloop) }\end{array}$ & Hydrologisch model \\
\hline & & Kwel & Hydrologisch model \\
\hline \multirow[t]{4}{*}{ *Afwateringsgebied } & & $\begin{array}{l}\text { Versnelde afvoer } \\
\text { t.o.v. natuurlijk }\end{array}$ & Hydrologisch model \\
\hline & $\begin{array}{l}\text { Chemische stress } \\
\text { (diffuse bronnen) }\end{array}$ & Nutriënten & GIS \\
\hline & & Slib & GIS \\
\hline & & Toxiciteit & GIS \\
\hline \multirow[t]{7}{*}{ Beeknetwerk } & $\begin{array}{l}\text { Chemische stress } \\
\text { (puntbronnen) }\end{array}$ & RWZI & Waterschapsbestand \\
\hline & & Overstort & Waterschapsbestand \\
\hline & & Waterinlaat & Waterschaps-bestand \\
\hline & & Infrastructuur & Waterschapsbestand \\
\hline & & Spoor & Waterschapsbestand \\
\hline & & Industrie & Waterschapsbestand \\
\hline & & Overige & Waterschapsbestand \\
\hline \multirow[t]{12}{*}{ Beekloop } & $\begin{array}{l}\text { Systeem- } \\
\text { voorwaarden } \\
\text { (fysische stress) }\end{array}$ & Temperatuur & Waterschapsbestand \\
\hline & & Verhang & AHN \\
\hline & & Beschaduwing & Waterschapsbestand \\
\hline & $\begin{array}{l}\text { Hydrologische } \\
\text { stress }\end{array}$ & Piekafvoeren & Hydrologisch model \\
\hline & & Lage afvoer/stagnatie & Hydrologisch model \\
\hline & & Droogval & Waterschapsbestand \\
\hline & & Stromingsvariatie & Waterschapsbestand \\
\hline & & Stuwing & Waterschapsbestand \\
\hline & $\begin{array}{l}\text { Morfologische } \\
\text { stress }\end{array}$ & Profiel & Waterschapsbestand \\
\hline & & Substraat & Waterschapsbestand \\
\hline & & Oeverbegroeiing & Waterschapsbestand \\
\hline & Beheerstress & Maaibeheer & Waterschapsbestand \\
\hline
\end{tabular}




\subsection{1 (Geo)hydrologische stress}

(Geo)hydrologische stressoren afkomstig vanuit het afwaterings-, zijstroomgebied en de bufferzone langs/rondom het waterlichaam betreffen de (grond)waterstromen van afspoeling, uitspoeling en kwel (Figuur 14.1). Voor het berekenen van deze parameters zijn vaak regionale grond- en oppervlaktewatermodellen beschikbaar. Bijvoorbeeld gebruikt het Waterschap Limburg het modelinstrumentarium IBRAHYM. De parameterisering is als volgt:

- Afspoeling of runoff $\left(\mathrm{mm}^{3} / \mathrm{d}\right)$. Runoff is de afvoer van neerslag (geen sneeuw) die niet snel genoeg kan infiltreren en bovendien niet kan worden geborgen op het maaiveld, naar het oppervlaktewaterlichaam.

- Uitspoeling of drainage $\left(\mathrm{m}^{3} / \mathrm{d}\right)$. Drainage is de afvoer van grondwater via drainagemiddelen (greppels, droogvallende sloten/slenken, drains).

- Uitspoeling of flux naar de watergang $\left(\mathrm{m}^{3} / \mathrm{d}\right)$. De aanvoer van water vanuit het regionale grondwater naar de beekbodem.

- Kwel ( $\left.\mathrm{m}^{3} / \mathrm{d}\right)$. De aanvoer van water vanuit het regionale grondwater naar de oeverzone (beekdalzone).

\section{FIGUUR 14.1}

De belangrijkste waterstromen vanuit het stroomgebied naar het waterlichaam.

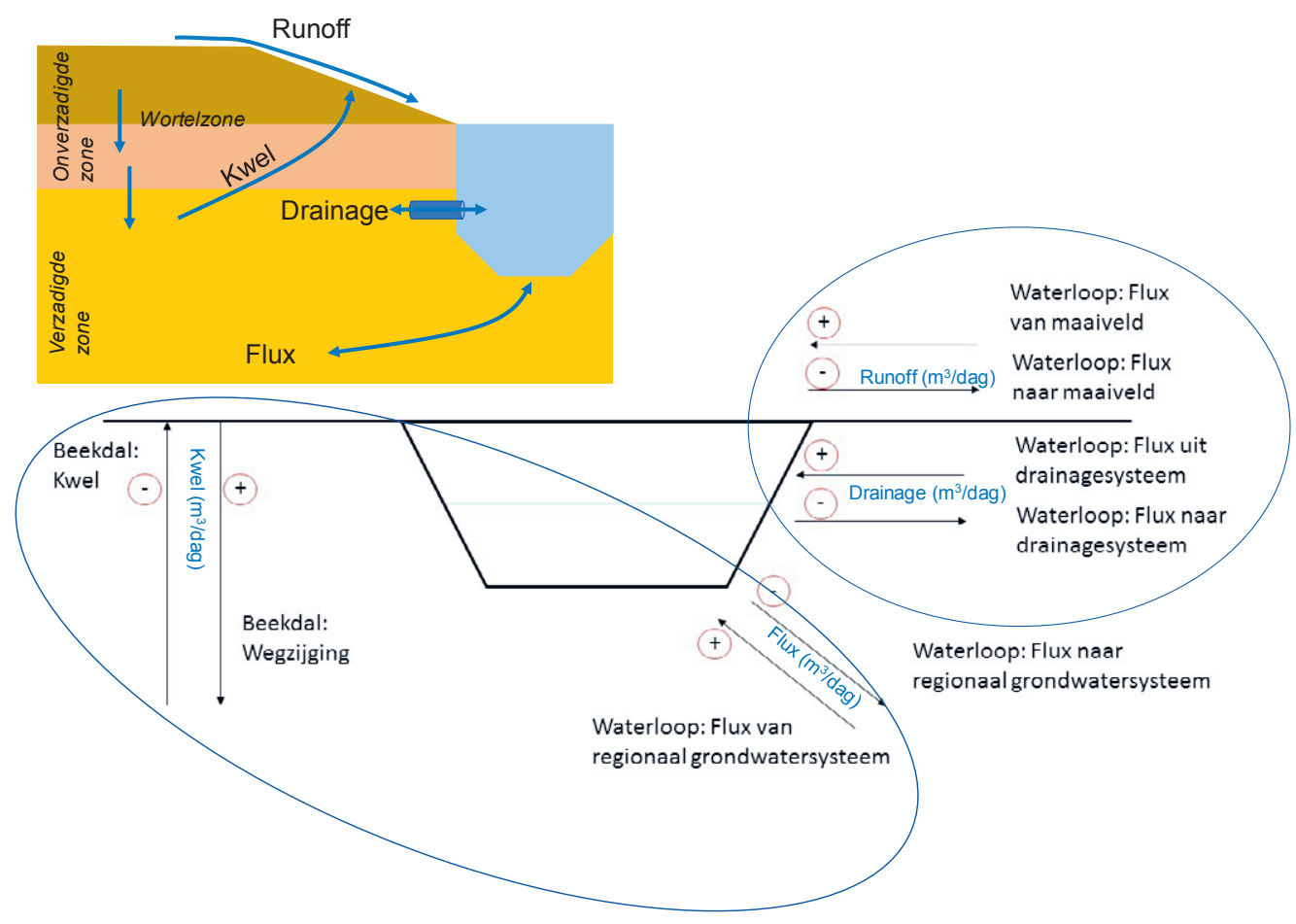

Het verschil tussen de natuurlijke en huidige afvoer levert de term 'versnelde afvoer t.o.v. natuurlijke situatie'.

Voor geen van de hydrologische stressoren is een gekwantificeerde maat voor ecologische relevantie beschikbaar. Er is op basis van de analyse van de Groote Molenbeek een relatieve schaal opgesteld om de parameters te classificeren. De hydrologische stressoren zijn afhankelijk van de grootte van het bijbehorende afwateringsgebied. Een groter gebied levert immers in potentie meer water. Er dient nog onderzocht te worden of en hoe verschillen in oppervlak en lengte van segmenten optimaal verdisconteerd kunnen worden. De mate van kwel naar een beekbodem en beekdal heeft een sterk positieve invloed op het ecosysteem en is daarom als positief geclassificeerd.

Samenvattend zijn 5 (geo)hydrologische parameters in de SESA Groote Molenbeek opgenomen (Tabel 14.2). 


\section{TABEL 14.2}

Samenvattend overzicht van de (geo)hydrologische stress opgenomen in de SESA Groote Molenbeek. Naarmate er meer af- en uitspoeling optreedt is de stress groter (een negatievere waarde). Naarmate er meer kwel optreedt (een negatievere waarde) is er minder stress. Naarmate en een meer versnelde afvoer t.o.v. de natuurlijke situatie optreedt is er meer stress (een positievere waarde).

\begin{tabular}{lcc}
\hline Parameter & Range & Klasse \\
\hline Runoff $\left(\mathrm{m}^{3} / \mathrm{d}\right)$ & $<-0.15->0$ & $-5 \mathrm{t} / \mathrm{m} 1$ \\
Drainage $\left(\mathrm{m}^{3} / \mathrm{d}\right)$ & $<-800->0$ & $-5 \mathrm{t} / \mathrm{m}^{1}$ \\
Flux naar de watergang $\left(\mathrm{m}^{3} / \mathrm{d}\right)$ & $<-400->0$ & $-5 \mathrm{t} / \mathrm{m}^{1}$ \\
Kwel $\left(\mathrm{m}^{3} / \mathrm{d}\right)$ & $<-200->0$ & $-5 \mathrm{t} / \mathrm{m} 1$ \\
Versnelde afvoer t.o.v. natuurlijk (ratio \% & $>250-<50$ & $-5 \mathrm{t} / \mathrm{m} \mathrm{0}$ \\
gemiddelde afvoer : huidig/natuurlijk) & & \\
\hline
\end{tabular}

\subsection{2 (Geo)morfologische stress}

In de laaglandbeken speelt geomorfologische stress nauwelijks een rol, behalve bij situaties zoals egalisering, diepe afgravingen of het doorboren van keileemlagen. Veranderingen in de terreinhelling hebben hooguit lokaal invloed op de oppervlakkige afstroming. In het heuvelland is dit echter wel relevant. Ook kunnen beken opgeleid zijn, dan is er wel sprake van stress. Voor de Groote Molenbeek is de geomorfologische stress niet meegenomen, omdat dit aspect niet aan de orde was. SESA bevat daarom op dit moment nog geen component (geo-)morfologische stress.

\subsection{3 (Geo)chemische stress}

De (geo)chemische stress, zoals de natuurlijke achtergrondbelasting, is niet uitgewerkt in het stroomgebied van de Groote Molenbeek, omdat het hier geen rol speelt.

\subsubsection{Chemische stress uit diffuse bronnen}

Als ecologisch relevante chemische stressfactoren zijn nutriënten, slib, toxische stoffen en soms ook het chloridegehalte van belang. Chemische stressoren uit landgebruik zijn diffuus en betreffen vanaf het land getransporteerde stoffen: nutriënten, slib en toxicanten. In gebieden waar de landbouw overheerst is diffuse toevoer vaak de dominante bron van stoffen in het oppervlaktewater (Drewry et al. 2006). Deze toevoer vindt plaats via oppervlakkige afspoeling vanaf het land en via uitspoeling door drainage en via het grondwater, m.a.w. het volgt de waterstromen. Deze toevoer komt uit actuele (huidig landgebruik) en historische bronnen (nalevering door historisch landgebruik of processen zoals de veraarding van veenbodems).

De in- en uitstroom van een segment is het resultaat van bronnen en retentie in de omgeving (Groenendijk et al. 2013). Bronnen omvat de toevoer van water en stoffen naar het waterlichaam, bijvoorbeeld bemesting door de landbouw. Retentie is de vermindering van de hoeveelheid stoffen (bijvoorbeeld nutriënten) tijdens de weg naar en in het waterlichaam, voordat het water het uitstroompunt heeft bereikt. Retentie bestaat uit tijdelijke en permanente opslag in de terrestrische bodem, in organismen (bijvoorbeeld waterplanten), in de waterbodem (sedimentatie) en door emissies naar de atmosfeer (bijvoorbeeld denitrificatie).

Algemene kentallen van stofstromen van nutriënten, nutriënten gebonden aan slib, toxische stoffen en chloride (mits aan de orde) per landgebruikstype zijn geclassificeerd naar mate van stress per landgebruiksklasse en bodemtype.

\section{Af-en uitspoeling van nutriënten}

Nutriënten in het water kunnen zowel een directe (voedingsstof, toxische werking) als een indirecte stressor zijn, bijvoorbeeld hoge concentraties nutriënten die leiden tot extreme variaties in zuurstofniveau en zuurgraad. De uit- en afspoeling uit landbouwgronden is gemiddeld ongeveer 59\% van de totale P-belasting en ruim 54\% van de N-belasting van het regionale oppervlaktewater en bedragen de overige landbouwemissies circa 7\% voor P en circa 2.5\% voor N (Groenendijk et al. 2017). 
SESA maakt gebruik van een eenvoudige benadering waarbij de belasting op het oppervlaktewater is afgeleid van het type landgebruik en het hoofdbodemtype. Dit zijn twee macroscopische karakteristieken waarmee een goede voorspelling kan worden gedaan van de belasting van het oppervlaktewater (De Wit 1999). Het landgebruik wordt verdeeld naar hoofdgrondgebruik. Het bodemtype is verdeeld in zand, klei en veen, die elk een ander gedrag vertonen wat betreft uit- en afspoeling van stoffen. Naast deze twee factoren spelen ook grondwaterstand, hellingshoek (vooral van belang in hellende gebieden zoals Zuid-Limburg) en aanwezigheid van bufferstroken een rol. Databeschikbaarheid bepaalt of hier gebruik van kan worden gemaakt.

Bronnen van informatie die meegenomen zijn bij het vaststellen van de stressklasse zijn voor de afspoeling van fosfor en stikstof: De Koeijer \& Wossink 1990, Kruijne 1997, STOWA 2002, Bouwmans et al. 2003, Pieterse 2003, Willems et al. 2005, Niemeyer et al. 2007, Schouwmans et al. 2008, Blann 2009, Groenendijk 2016. De omzetting leunt sterk op de scenariostudie van Schouwmans et al. (2002) voor de Nederlandse situatie voor het jaar 2018.

\section{Afspoeling van slib}

Slib is van indirecte invloed op het zuurstofgehalte en de nutriëntenhuishouding. Een negatief effect op de ecologie kan ook ontstaan door instabiliteit van de waterbodem als gevolg van een toename van slib en opvulling van de poriën (interstitiële ruimtes) in het beddingsubstraat (Mackay \& Kalff 1969, Tolkamp 1980).

Over de afspoeling van slib, en vooral van de aan slib gebonden nutriënten en toxische stoffen, is erg weinig literatuur beschikbaar. Dos Reis Oliveira et al. (2018) zagen dat in runoff-sediment het percentage organisch materiaal significant afnam tussen bos $(62 \% \pm 11)$, grasland $(44 \% \pm 2)$ en bouwland $(25 \% \pm 8)$. De C/N-ratio was hoger in bos $(17 \pm 1)$ dan in grasland $(14 \pm 0.5)$ en bouwland (14 \pm 1$)$, terwijl het anorganisch fosfaat hoger was in bouwland (19 \pm 5$)$ dan in grasland (10 \pm 6$)$ en bos $(3 \pm 0.5)$. Op basis van deze metingen zijn stressklassen aan het landgebruik toegekend. Voor bebouwd gebied is een lage stressklasse gekozen, omdat het slib er deels afspoelt, maar ook deels in het riool verdwijnt.

\section{Af- en uitspoeling van toxische stoffen}

Toxische stoffen zoals bestrijdingsmiddelen en zware metalen kunnen al bij kleine hoeveelheden (>0.1 $\mu \mathrm{g} / \mathrm{L}) \mathrm{de}$ structuur en het functioneren van aquatische levensgemeenschappen aantasten door dodelijke en ecosysteem-gerelateerde effecten (Blann 2009). Er is nog veel onduidelijkheid over welke bestrijdingsmiddelen voor welk organisme in welke mate toxisch zijn.

De huidige belasting met zware metalen van de bodem is afkomstig van bemesting. Alleen voor lood en arseen speelt de atmosferische depositie een belangrijke rol. Door de sterke binding van zware metalen aan de bodem accumuleren belastingen over langere tijd en daarom is de historische belasting van grote invloed op de huidige concentraties van zware metalen in het grondwater en dus in het naar het oppervlaktewater afstromende water. Het huidig bodemgebruik heeft dus minder invloed op de huidige belasting. Op basis van Römkens et al. (2003) is de belasting met zware metalen bij verschillend landgebruik geclassificeerd.

Voor de belasting met bestrijdingsmiddelen is cumulatieve milieubelasting door Snoo \& Vijver (2012) omgezet in Milieu-Indicator-Punten (MIP) voor de milieubelasting van oppervlaktewater door drift bij gewasbescherming (en het aantal norm overschrijdende stoffen van de ecotoxicologische norm (MKN/MTR). Hieruit is het aantal stoffen en de chronische milieubelasting opgenomen in de stressorclassificatie.

Voor bebouwd gaan we ervan uit dat een deel naar het riool verdwijnt. Op basis van deze metingen is een stressklasse toegedeeld.

Samenvattend zijn van de diffuse chemische parameters 33 landgebruikstypen gecombineerd met 3 hoofdbodemtypen (correctiefactor afhankelijk van bodem is van groot naar klein zand>veen>klei) tot 99 combinaties van stressoren voor nutriënten, slib, toxische stoffen in SESA Groote Molenbeek opgenomen (Tabel 14.3). 
TABEL 14.3

Samenvattend overzicht van de landgebruik gerelateerde diffuse chemische stress door af- en uitspoeling van nutriënten, slib en toxische stoffen, zoals opgenomen in de SESA Groote Molenbeek. De exacte klassengrenzen zijn opgenomen in het SESA rekenmodel.

\begin{tabular}{lccc} 
Landgebruik & Range klasse & & \\
\hline & Nutriënten & Slib & Toxiciteit \\
\hline Bouwland & $-5--4$ & -5 & $-5--2$ \\
Glastuinbouw & -4 & -5 & -5 \\
Boom- en fruitkwekerijen & -4 & -5 & -3 \\
Intensief grasland & -3 & -3 & -1 \\
Extensief grasland & -1 & $-1-0$ & 0 \\
Bebouwd & $-2-0$ & -1 & $-3-0$ \\
Infrastructuur & -2 & 0 & -3 \\
Natuur & 0 & & 0 \\
\hline
\end{tabular}

Saliniteit

Saliniteit of uitspoeling van chloride is een bijzondere situatie, die alleen relevant is wanneer brakke of zoute kwel of zoutindringing optreedt (stressklasse -5).

\section{Atmosferische depositie open water}

De aanvoer van fosfor met atmosferische depositie wordt in de EmissieRegistratie en door het CBS sinds 1995 op 0 gesteld; van der Bolt et al. (2013) gaan uit van 0-1\%.

De aanvoer van stikstof, uitgedrukt in $\mathrm{kg} / \mathrm{ha} / \mathrm{jr}$, kan wel groter zijn en is bijvoorbeeld te vinden in het Compendium voor de Leefomgeving (https://www.clo.nl); van der Bolt et al. (2013) gaan uit van 8-11\%, terwijl recent het PBL (2020) tot circa $4-5 \%$ kwam. We gaan ervan uit dat deze depositie redelijk gelijk over een stroomgebied is verdeeld en daarnaast een beperkt aandeel (vaak $<5 \%$ ) heeft in de totale aanvoer door diffuse bronnen. Deze wordt daarom niet standaard opgenomen in de analyse. Alleen voor geïsoleerde, zwak gebufferde wateren is deze diffuse bron van belang en kan daar worden opgenomen.

\section{Overige emissies o.a. verkeer, vervoer, huishoudelijke lozingen}

Voor de emissies van verkeer en vervoer nemen we aan dat deze vooral op verhard oppervlak een rol spelen en oppervlakkig afspoelen (kleiner deel) en terecht komen in de RWZI's, het riool (overstorten) en via afgekoppeld regenwater (groter deel). Deze emissies komen vooral aan de orde bij urbaan "verhard" landgebruik en puntlozingen (RWZI, overstort en regenwaterlozingen). Daar waar deze emissies direct of op bermsloten e.d. uitkomen worden ze wel meegenomen (zie puntlozingen).

\section{Historische belasting}

In een modelanalyse van de regionale bijdragen van fosfor $(\mathrm{P})$ en stikstof $(\mathrm{N})$ aan de belasting van het oppervlaktewater komen van der Bolt et al. (2013) voor stroomgebieden van laaglandbeken in Nederland tot het inzicht dat diepe kwel een beperkte bijdrage levert (P 2-3\%, N 5-7\%) en dat de historische belasting (nalevering uit de diepere bodem) groot kan zijn (P 9\%, N 59\%). Deze cijfers betreffen een periode van circa 40 jaar. De laatste tientallen jaren is het landgebruik waarschijnlijk niet sterk veranderd. Ook betreft het algemene cijfers; het verdient daarom aanbeveling om deze data voor afzonderlijke gebieden te preciseren. Daarom nemen we aan dat de historische belasting in verhouding staat tot de huidige belasting en is deze vooralsnog niet afzonderlijk in de SESA opgenomen. 


\subsubsection{Retentie van nutriënten}

Van de totale P-belasting van het regionale oppervlaktewater komt voor P ca. $40 \%$ en voor N ca. $30 \%$ niet tot afvoer naar het Rijkswater als gevolg van retentie in het systeem. De retentie vanaf de haarvaten wordt in het algemeen voor P op $50 \%$ gezet voor diffuse bronnen en op 20\% voor puntbronnen (Kronvang et al. 2004), voor N in Limburg op 10-30\% (Groenendijk et al. 2017).

Retentie van nutriënten is in de berekeningen voor de Groote Molenbeek meegenomen als de halvering van de stress aan het einde van ieder segment.

\subsubsection{Chemische stress uit puntbronnen}

RWZIs

Veel stoffen komen in hogere concentraties in het RWZI-effluent voor dan de voor deze verbindingen geldende streef- en/ of grenswaarden voor oppervlaktewateren. Dat betekent dat de RWZI's bijdragen aan de belasting van het oppervlaktewater. Om hieraan een stressklasse te verbinden moeten de stofgehalten in het effluent van de RWZI vergeleken worden met de ecologische eisen die het ontvangend water stelt en de afvoer van dat ontvangend systeem. Naarmate dat verschil groter is zal de stressklasse hoger zijn.

Indien de belasting per component bekend is kunnen RWZI's een aangepaste stressscore krijgen voor elk van de stressoren die wordt overschreden. Dit is nog niet nader ingevuld voor de afzonderlijke stressoren. Indien de overall belasting ook niet bekend is worden de waarden op maximaal gesteld (Tabel 14.4).

\section{TABEL 14.4}

Samenvattend overzicht van de chemische stress uit een RWZI opgenomen in de SESA Groote Molenbeek. De exacte klassengrenzen zijn opgenomen in het SESA rekenmodel.

\begin{tabular}{lcc}
\hline Parameter & Range & Klasse \\
\hline Ratio: debiet RWZI / debiet ontvangend & $>3-0$ & -5 t/m 0 \\
water & & \\
Terugval optie: & -5 & 1 klasse \\
Nutriënten & -5 & 1 klasse \\
Slib & -5 & 1 klasse \\
Toxicanten & -3 & 1 klasse \\
Saliniteit &
\end{tabular}

\section{Overstorten}

Als er heftige buien vallen, kunnen overstorten in werking treden en komt het teveel aan regenwater en ongezuiverd afvalwater uit het riool in de beken terecht. De levensgemeenschap wordt, weliswaar tijdelijk, negatief beïnvloed via verstikking (organische belasting zorgt voor daling zuurstofconcentratie), vergiftiging (direct door een concentratieverhoging van voor de levensgemeenschap in de beek schadelijke stoffen, indirect via stoffen die vrijkomen bij zuurstofloosheid) en verslibbing door het overstortende slib. Daarnaast kunnen hydrologische effecten, zoals hydraulische stress (piekafvoer) en morfologische aantasting optreden, maar over de gevolgen daarvan is weinig bekend.

De eigenlijke impact van een overstort hangt af van de frequentie en het volume van de vuiluitworp t.o.v. het debiet van het ontvangende water. Op basis van data van de Groote Molenbeek is een stressklasse verdeling opgesteld en in SESA opgenomen. Deze moet nog getoetst worden aan andere waterlichamen (Tabel 14.5). 


\begin{tabular}{lcc}
\hline Parameter & Range & Klasse \\
\hline Aantal overstortingen/jaar & $>18-0$ & $-5 \mathrm{t} / \mathrm{m} \mathrm{0}$ \\
\hline Debiet overstort / debiet ontvangend & op droge & $-5 \mathrm{t} / \mathrm{m} 0$ \\
waterlichaam & watergang/ $>2-0$ & \\
Terugval optie: & & \\
Aantal overstorten per segment: & $>2-0$ & $-5 \mathrm{t} / \mathrm{m}-3 / 0$ \\
Bovenloop & $>3-0$ & $-5 \mathrm{t} / \mathrm{m}-2 / 0$ \\
Middenloop & $>4-0$ & $-5 \mathrm{t} / \mathrm{m} 0$ \\
Benedenloop & & \\
\hline
\end{tabular}

\section{Industriële puntlozingen}

Binnen het stroomgebied worden ook alle industriële lozingen meegenomen. Deze kunnen een bron zijn van ammonium, zware metalen en andere toxische stoffen, sulfaat, chloride, fosfor, calcium en bicarbonaat. Ook historische lozingen kunnen nog een bijdrage aan de stress leveren indien nalevering plaats vindt vanuit de bodem, oeverzone of stortplaatsen.

Toxiciteit voor toxische stoffen kan worden uitgedrukt in de PNEC-waarde, de 'predicted no-effect concentration'. Beneden deze waarde zijn er geen negatieve effecten van blootstelling binnen een ecosysteem.

Lozingen kunnen een aparte stressklasse krijgen voor elk van de stressoren die wordt overschreden (Tabel 14.6).

\section{TABEL 14.6}

Samenvattend overzicht van de chemische stress uit industriële lozingen opgenomen in de SESA Groote Molenbeek. De exacte klassengrenzen zijn opgenomen in het SESA rekenmodel.

\begin{tabular}{lcc}
\hline Parameter & Range & Klasse \\
\hline Zware metalen & $>2 *$ PNEC- $=<$ PNEC & $-5 \mathrm{t} / \mathrm{m} 0$ \\
Overige toxicanten & aanpassen aan stoffen & $-5 \mathrm{t} / \mathrm{m} 0$ of 1 klasse \\
Nutriënten & met als terugval optie: -5 & 1 klasse \\
Saliniteit & -5 & 1 klasse \\
\hline
\end{tabular}

\section{Overige puntbronnen}

Chemische stress uit andere puntbronnen betreft bijvoorbeeld kassen, wanneer deze geen onderdeel uitmaken van landgebruik (meestal wel), of andere lozingen, zoals uit visvijvers. Voor de emissies van verkeer en vervoer waar deze emissies direct of op berm- en spoorsloten e.d. uitkomen worden ze wel meegenomen (Tabel 14.7). 
Samenvattend overzicht van de chemische stress uit overige puntbronnen opgenomen in de SESA Groote Molenbeek. De exacte klassengrenzen zijn opgenomen in het SESA rekenmodel.

\begin{tabular}{lccccc}
\hline Parameter & Range & & & & Klasse \\
\hline & nutriënten & slib & toxiciteit & saliniteit & \\
\hline Visvijver & -3 & 0 & -1 & 0 & 1 klasse \\
\hline Infrastructuur & 0 & -1 & -2 & -1 & 1 klasse \\
Wegwater & 0 & -1 & -2 & -1 & 1 klasse \\
Bermsloot snelweg & 0 & -1 & -2 & -1 & 1 klasse \\
Snelweg & 0 & -1 & -2 & -1 & 1 klasse \\
Bermsloot & -1 & 0 & -2 & 0 & 1 klasse \\
Spoorsloot & & & & & \\
\hline
\end{tabular}

\section{Waterinlaat/-aanvoer (gebiedsvreemd water)}

Waterinlaat is een toevoerpost in de waterbalans, die vooral in droge perioden van belang is en daarbij een relatief aandeel inneemt. Waterinlaat water kan ook van chemische samenstelling verschillen t.o.v. het ontvangend water. Het water kan rijker zijn aan bijvoorbeeld bicarbonaat, sulfaat, calcium, nutriënten enzovoorts. Waterinlaat kan naast directe eutrofiëring door toevoer van voedselrijk water of de-eutrofiëring door toevoer van voedselarm(er) water leiden tot afbraak van organisch materiaal, zuurstoftekorten, interne eutrofiëring, interne de-eutrofiëring (in minerale (zand)bodems kan door toegenomen hardheid bij hogere $\mathrm{pH}$ fosfaat neerslaan met calciumcarbonaat en treedt P-immobilisatie op), ijzergebrek, sulfidetoxiciteit en ammoniumtoxiciteit (Vermaat et al. 2013).

Wanneer bekend is hoeveel water van een bepaalde chemische samenstelling ingelaten wordt en wat de referentie en de afvoer van het ontvangend water is, kan de hydrologische en chemische beïnvloeding worden bepaald (Tabel 14.8).

\section{TABEL 14.8}

Samenvattend overzicht van de chemische stress uit waterinlaat opgenomen in de SESA Groote Molenbeek. De exacte klassengrenzen zijn opgenomen in het SESA rekenmodel.

\begin{tabular}{lcc}
\hline Parameter & Range & Klasse \\
\hline Ratio debiet RWZI / debiet ontvangend water & $>3-0$ & $-5 \mathrm{t} / \mathrm{m} 0$ \\
Terugval optie 1: & & \\
Kwaliteitseffect & sterk - niet & $-5 \mathrm{t} / \mathrm{m} \mathrm{0}(4 \mathrm{klassen})$ \\
Sulfaat (mg/l) & $>19-<10$ & $3 \mathrm{klassen}$ \\
Alkaliniteit (meq/l) & $->2-<1$ & $3 \mathrm{klassen}$ \\
Ca+Mg (mg/l) & $>180-<80$ & $3 \mathrm{klassen}$ \\
Terugval optie 2: & -5 & 1 klasse \\
Aanwezig & & \\
\hline
\end{tabular}

\subsubsection{Fysische stress (systeemvoorwaarden) \\ Temperatuur}

De factor temperatuur is sterk afhankelijk van het watertype. Globaal worden voor organismen als optimum de jaargemiddelde waarden van $10-12^{\circ} \mathrm{C}$ voor bronnen, tot $12-16^{\circ} \mathrm{C}$ voor koele bovenlopen en tot $18^{\circ} \mathrm{C}$ voor midden- en benedenlopen gezien. De mate van afwijking bepaalt vervolgens de stressklasse. Boven de $28^{\circ} \mathrm{C}$ beschouwen we als lethaal voor veel beekorganismen (Tabel 14.9). 


\section{Beschaduwing (licht)}

Licht (klimatologische variabele) is een belangrijke systeemvoorwaarde. De variabele licht heeft vooral effect op het ecologisch functioneren van stromende wateren via de mate van beschaduwing. Het onderzoek aan effecten van beschaduwing in beken heeft laten zien dat beschaduwing pas vanaf een bedekking van 70\% een doorslaggevend positief effect heeft op de beek en het traject stroomafwaarts van een begeleidend bos van 800-1000 m lengte (Verdonschot 2016: Tabel 14.9).

\section{Verhang/Verval}

Helling of verval (geomorfologische variabele) is een belangrijke systeemvoorwaarde. Door kanalisatie en het plaatsen van stuwen (regulatie) zijn de bodem- en waterverhanglijn die in een evenwichtssituatie elkaar min of meer volgen) vaak verkleind. De bodemverhanglijn kan een grilliger patroon volgen als door aanslibbing tussen bijvoorbeeld planten een onregelmatige bodem ontstaat. Bij aanwezigheid van stuwen kan beter uitgegaan worden van de terreinhelling als maat voor het potentiele verval (Tabel 14.9).

\section{TABEL 14.9}

Samenvattend overzicht van de fysische stress opgenomen in de SESA Groote Molenbeek. De exacte klassengrenzen zijn opgenomen in het SESA rekenmodel.

\begin{tabular}{lcc}
\hline Parameter & Range & Klasse \\
\hline Temperatuur $\left({ }^{\circ} \mathbf{C}\right)$ & $>18-10$ & 3 klassen \\
Bron & $>28-12$ & 3 klassen \\
Bovenloop & $>28-<18$ & 3 klassen \\
Midden- en benedenloop & $>6-0$ & \\
i.c.m. overschrijdingsfrequentie per jaar & & $-5-0$ \\
\hline $\begin{array}{l}\text { Schaduw \% } \\
\% \text { Schaduw bij loodrechte projectie bladerdek }\end{array}$ & $0-100 \%$ & \\
\hline $\begin{array}{l}\text { Verhang / terreinhelling } \\
\text { Bodemverhang } \mathrm{m} / \mathrm{km}\end{array}$ & $<0.5->4$ & 5 positieve klassen \\
$\begin{array}{l}\text { Terugval optie: } \\
\text { Terreinhelling } \mathrm{m} / \mathrm{km}\end{array}$ & $<0.5->4$ & 5 positieve klassen \\
\hline
\end{tabular}

\subsubsection{Hydraulische stress}

Voor de hydraulische omstandigheden in een waterlichaam, vooral in een beek, zijn de dynamiek en extremen in de hydraulische omstandigheden ecologisch van groot belang. De belangrijkste parameters zijn:

- Basisafvoer: De basisafvoer vormt een relatief kleine component van de totale jaarlijkse afvoer, maar is belangrijk voor het behouden van voldoende watervoerendheid en stroomsnelheid tijdens droge perioden en wordt vaak omschreven als de continue afvoer van grondwater naar oppervlaktewater. Definities zijn of 1/100Q: de afvoer die in slechts $10 \%$ van het zomerhalfjaar wordt onderschreden (een zeer lage afvoer) of de gemiddelde zomerafvoer (juni t/m augustus).

- Piekafvoer: jaarlijkse hoogste afvoer.

- Stagnatie: het water staat stil.

- Droogval: de watergang is droog.

- Jaarlijkse extremen: Organismen ervaren afhankelijk van hun levenscyclus (kritische fase) de gemiddelde winter-, voorjaars- of zomerafvoer en de jaarlijkse piekafvoer brengt hierin een moment van extreme dynamiek in teweeg.

- Onregelmatige dynamiek: dagelijkse wisselingen in de afvoer. 
Piekafvoeren, lage afvoeren en droogval hebben een grote ecologische invloed door of erosie of door sedimentatie en het ontstaan van gebrek aan zuurstof en wegvallen van waterbeweging. De klassengrenzen voor de afvoerparameters zijn ingeschat op basis van de situatie in de Groote Molenbeek i.r.t. kennis van de effecten van piekafvoeren (Verdonschot $e t$ al. 2010), lage afvoer en droogval (Verdonschot et al. 2015). De parameters droogval, stroming (parameter opgebouwd uit de stromingsvariatie en de aanwezigheid van stroomkuilen), en stuwing (parameter opgebouwd uit de aanwezigheid van stuwen, vispassages en bodemvallen) zijn gegeven in Tabel 14.10).

\section{TABEL 14.10}

Samenvattend overzicht van de hydraulische stress opgenomen in de SESA Groote Molenbeek. De exacte klassengrenzen zijn opgenomen in het SESA rekenmodel.

\begin{tabular}{|c|c|c|}
\hline Parameter & Range & Klasse \\
\hline \multicolumn{3}{|l|}{ Afvoer } \\
\hline Ratio jaarlijkse piekafvoer : basisafvoer & $>28-0$ & $-5-0$ \\
\hline \multicolumn{3}{|l|}{ Lage afvoer en stagnatie } \\
\hline Ratio zomerafvoer : basisafvoer & $>3.0-<1.1$ & $-5-0$ \\
\hline \multicolumn{3}{|l|}{ Droogval } \\
\hline Duur droogval (dagen) & $>90-0$ & $-5-0$ \\
\hline Frequentie over jaren & jaarlijks - permanent (>25 jr) & $-5-0$ \\
\hline \multicolumn{3}{|l|}{ Stroming } \\
\hline Stromingsvariatie & $\begin{array}{l}\text { geen (volledig uniform) - zeer } \\
\text { groot ( } 4 \text { stromingsbeelden) }\end{array}$ & 5 klassen \\
\hline Stroomkuilen & geen - aanwezig & 3 klassen \\
\hline \multicolumn{3}{|l|}{ Stuwing } \\
\hline $\begin{array}{l}\text { Aanwezigheid van stuwen, vispassages en } \\
\text { bodemvallen (= aantal * stressklasse) }\end{array}$ & stuw - geen & 4 klassen \\
\hline
\end{tabular}

\subsubsection{Morfologische stress}

Natuurlijke beken hebben een kronkelende loop en een onregelmatig dwarsprofiel (Eekhout \& Hoitink 2014) en andere natuurlijke wateren hebben een onregelmatige oevervorm. Deze natuurlijke morfologie staat haaks op de aanwezigheid van bijvoorbeeld bodem- en of taludbeschoeiing.

Morfologische stress is onderverdeeld naar drie groepen; profiel, substraat en oeverbegroeiing. Iedere groep is onderverdeeld naar respectievelijk 7, 6 en 4 stressoren (Tabel 14.11). 


\begin{tabular}{|c|c|c|}
\hline Parameter & Range & Klasse \\
\hline \multicolumn{3}{|l|}{ Profiel } \\
\hline Sinuositeit (kortste lengte/lengte) & $<1.05-<1.3$ & $-5-0$ \\
\hline Type dwarsprofiel I-r & $\begin{array}{l}\text { steil normprofiel - graduele } \\
\text { overgang/moeras/plasdras }\end{array}$ & 5 klassen \\
\hline Oevervorm I-r & steil - onregelmatig & 4 klassen \\
\hline & geen (overal normale breedte) - & \\
\hline Breedtevariatie & $\begin{array}{l}\text { zeer groot (overal >3 typen; } \\
\text { >20\% beek) }\end{array}$ & 5 klassen \\
\hline Beschoeiing & tweezijdig - geen (incl. lokaal) & 3 klassen \\
\hline Beschoeiingstype & $\begin{array}{l}\text { steen structuurarm - geen / zeer } \\
\text { lokaal) }\end{array}$ & 5 klassen \\
\hline Erosieprofiel (> 20\%) & $\begin{array}{r}\text { gehele oeverhoogte } \\
\text { geërodeerd - geen of weinig }\end{array}$ & 3 klassen \\
\hline \multicolumn{3}{|l|}{ Substraat } \\
\hline Aanwezigheid hout in het water & $\begin{array}{c}\text { geen - boom aanwezig ( }>10 \\
\text { cm diameter) }\end{array}$ & 3 klassen \\
\hline Basissubstraat aard 1-2 (> 30\%) & slib - zand & 4 klassen \\
\hline Bladpakketten*** (> $25 \%$ ) & afwezig - aanwezig & 2 klassen \\
\hline Grindbedden aanwezig (aaneengesloten) & afwezig** - aanwezig & 2 klassen \\
\hline Zand-/grindbanken (2-3 x zo ondiep) & geen - aanwezig & 2 klassen \\
\hline Watervegetatie \%-bedekking & $100-0$ & 5 klassen \\
\hline \multicolumn{3}{|l|}{ Oeverbegroeiing } \\
\hline Bomen I- $r$ in beekprofiel & nee - ja & 2 klassen \\
\hline Dominante houtige oeverstructuur I-r & geen - bos & 4 klassen \\
\hline Houtige oeverstructuur \% I-r & $0-100$ & 5 klassen \\
\hline $\begin{array}{l}\text { Hoge } \quad(>1 \mathrm{~m}) \quad \text { persistente } \quad \text { kruidige } \\
\text { oevervegetatie }\end{array}$ & afwezig - aanwezig & 2 klassen \\
\hline
\end{tabular}

* Op plaatsen waar beek van nature dieper is ingesneden, zoals bij terrasranden en segmenten met een groter verhang is geen sprake van morfologische stress.

$* *$ Indien niet natuurlijk.

$* * *$ In langzaam stromende laaglandebeken.

\subsubsection{Stress door beheer en onderhoud}

Natuurlijke wateren worden niet onderhouden. Voor de stress gelden alleen die onderhoudsvormen waarbij het onderwatertalud en de onderwaterbodem worden gemaaid, of die waarbij aanwezige structuren worden verwijderd: baggeren (verwijderen detritus-, zand- en grindbanken, egalisatie) en verwijderen dood hout. Naarmate de frequentie van onderhoud toeneemt, neemt de mate van stress ook toe. Naast de frequentie van het onderhoud kan ook de fasering ervan, zoals stroombaanmaaien en afwisselend oevers maaien, onderdeel van de mate van stress of het ontbreken daarvan zijn. Wanneer bij het maaien een significant percentage van de vegetatie $(>20 \%)$ wordt gespaard, wordt een positieve klasse toegekend (Tabel 14.12). 
Samenvattend overzicht van stress door beheer en onderhoud zoals opgenomen in de SESA Groote Molenbeek. De exacte klassengrenzen zijn opgenomen in het SESA rekenmodel.

\begin{tabular}{lcc}
\hline Parameter & Range & Klasse \\
\hline $\begin{array}{l}\text { Maaibeheer } \\
\text { Schoningsfrequentie watergang }\end{array}$ & $>2-0$ & $-5-1$ (5 klassen) \\
Of indien meer bekend: & $5-0$ & 5 klassen \\
Maaiharken frequentie & $5-0$ & 5 klassen \\
Topklepelen frequentie & $1-0$ & 5 klassen \\
Handwerk frequentie & $5-0$ & 5 klassen \\
Maaiboot frequentie & & 2 klassen \\
Of indien minder bekend: & ja - nee & \\
Schoning & & \\
\hline
\end{tabular}

\subsubsection{Omgaan met missende gegevens}

Natuurlijk komt het voor dat er voor trajecten waarvoor een inschatting van de stress wordt gemaakt niet alle benodigde gegevens beschikbaar zijn. In dat geval wordt naar een manier gezocht om de beschikbare data te interpoleren (bijvoorbeeld tussen meetpunten voor morfologie) of uit alternatieve bronnen data te halen. Eventueel kan een stressor in zijn geheel worden overgeslagen.

\subsubsection{Samenvatting}

Samenvattend leidt de bovenstaande opsomming per stressorgroep en de bijhorende processen tot een lijst met parameters die is opgenomen in de SESA Groote Molenbeek (Tabel 14.13). 
Indeling naar schaal van stressorgroep, relevante processen en parameters opgenomen in SESA Groote Molenbeek. De exacte klassengrenzen zijn opgenomen in het SESA rekenmodel.

\begin{tabular}{|c|c|c|c|}
\hline Schaal & Stressorgroep & Proces & Parameter \\
\hline \multirow[t]{13}{*}{\begin{tabular}{l|} 
Afwaterings- $/$ \\
zijstroomgebied
\end{tabular}} & $\begin{array}{l}\text { (Geo)hydrologische } \\
\text { stress }\end{array}$ & Af- en uitspoeling & runoff, drainage \\
\hline & & Kwelstromen & flux, kwel \\
\hline & & $\begin{array}{l}\text { Versnelde afvoer t.o.v. } \\
\text { natuurlijk }\end{array}$ & versnelde afvoer \\
\hline & $\begin{array}{l}\text { (Geo)morfologische } \\
\text { stress }\end{array}$ & Terreinhelling (heuvelland) & terreinhelling (heuvelland) \\
\hline & $\begin{array}{l}\text { Chemische } \\
\text { stress (diffuus) }\end{array}$ & Nutriëntentoevoer & landgebruik, bodem \\
\hline & & Slibtoevoer & landgebruik, bodem \\
\hline & & Toevoer toxische stoffen & landgebruik, bodem \\
\hline & $\begin{array}{l}\text { Chemische } \\
\text { stress (punt) }\end{array}$ & RWZI lozing & RWZI \\
\hline & & Overstort lozing & overstort \\
\hline & & Industrie & lozingstype \\
\hline & & Waterinlaat & waterinlaat \\
\hline & & Infrastructuur afwatering & berm-, spoorsloot, industrieterrein \\
\hline & & Overige & visvijver \\
\hline \multirow[t]{6}{*}{ Bufferzone } & $\begin{array}{l}\text { Hydrologische } \\
\text { stress }\end{array}$ & Af- en uitspoeling & runoff, drainage \\
\hline & & Kwelstromen & flux, kwel \\
\hline & $\begin{array}{l}\text { Morfologische } \\
\text { stress }\end{array}$ & Terreinhelling buffer & terreinhelling buffer \\
\hline & $\begin{array}{l}\text { Chemische } \\
\text { stress (diffuus) }\end{array}$ & Nutriëntentoevoer & landgebruik, bodem \\
\hline & & Slibtoevoer & landgebruik, bodem \\
\hline & & Toevoer toxische stoffen & landgebruik, bodem \\
\hline \multirow[t]{13}{*}{ Waterlichaam } & $\begin{array}{l}\text { Fysische } \\
\text { (systeem)stress }\end{array}$ & Temperatuur & temperatuuroverschrijding \\
\hline & & Verhang & verhang \\
\hline & & Beschaduwing & schaduw \\
\hline & $\begin{array}{l}\text { Hydraulische } \\
\text { stress }\end{array}$ & Afvoerdynamiek & $\begin{array}{l}\text { piekafvoer, lage afvoer, stagnatie, } \\
\text { droogval }\end{array}$ \\
\hline & & Stroming & stromingsvariatie, stroomkuilen \\
\hline & & Stuwing & stuw, vispassage, bodemval \\
\hline & $\begin{array}{l}\text { Morfologische } \\
\text { stress }\end{array}$ & Profiel & $\begin{array}{l}\text { sinuositeit, breedtevariatie, } \\
\text { beschoeiing, } \\
\text { erosieprofiel, dwarsprofielen } \\
\text {,oevervorm }\end{array}$ \\
\hline & & Substraat & $\begin{array}{l}\text { basissubstraten, hout, blad, } \\
\text { grindbedden, } \\
\text { banken, watervegetatie }\end{array}$ \\
\hline & & Oeverbegroeiing & $\begin{array}{l}\text { bomen, houtige oeverstructuren, } \\
\text { kruidige oevervegetatie }\end{array}$ \\
\hline & $\begin{array}{l}\text { Chemische stress } \\
\text { (nalevering) }\end{array}$ & Nalevering bodem & waterbodem \\
\hline & $\begin{array}{l}\text { Stress Beheer } \\
\& \text { onderhoud }\end{array}$ & Maaibeheer & schoning \\
\hline & & Baggeren & baggeren \\
\hline & & Doorspoelen & doorspoelen \\
\hline
\end{tabular}




\section{BOUWSTENEN VAN DE BEREKENING}

\subsection{Berekenen van de multiple stress}

\subsubsection{Ruimtelijke indeling}

De multiple stress wordt allereerst per segment berekend. Ruimtelijk gezien zijn er vijf compartimenten die kunnen bijdragen aan de multiple stress die de ecologie binnen een segment ondervindt (Figuur 15.1):

- Multiple stress uit afwateringsgebied

- Multiple stress uit zijstroomgebied

- Multiple stress uit de beekdalbufferzone

- Multiple stress aanwezig in het waterlichaam

- Multiple stress aangevoerd vanaf het bovenstroomse segment

\section{FIGUUR 15.1}

Ruimtelijke eenheden onderscheiden voor lijnvormige vrij afstromende watergangen.

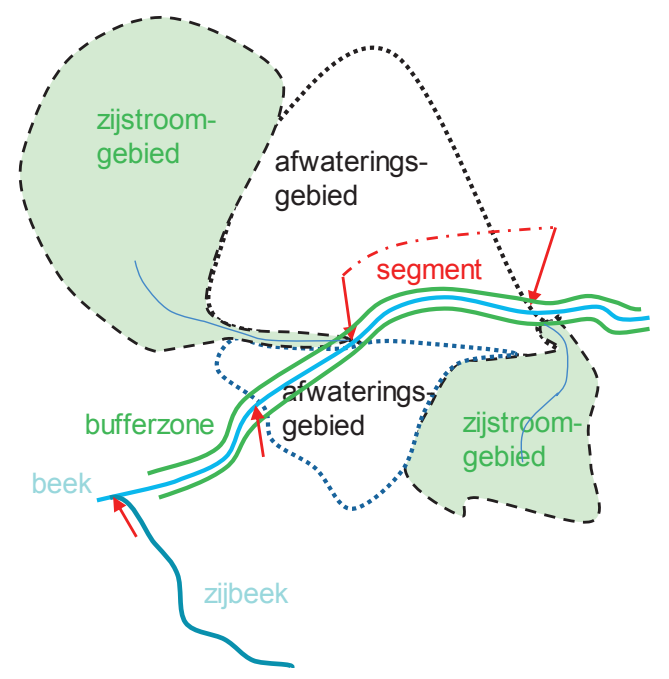

\subsubsection{Berekenen multiple stress per ruimtelijke eenheid/segment}

De parameters nodig voor het berekenen van de (geo)hydrologische stress worden met grond- en oppervlaktewatermodellen berekend per gebiedsoppervlak van afwaterings-, zijstroomgebied en beekdalbufferzone en per segment.

Voor de diffuse chemische stress afkomstig uit afwaterings-, zijstroomgebieden en beekdalbufferzones wordt het oppervlakte-aandeel van de combinatie landgebruik - bodemtype in de berekening meegenomen.

Voor de overige categorieën wordt de multiple stress per stressorgroep berekend en al dan niet gewogen. De berekening is onderdeel van het SESA rekenmodel.

Nadat per segment de gesommeerde multiple stress per hoofdgroep is berekend, wordt het relatieve aandeel bepaald. Hiervoor wordt het aandeel van de afvoer uit het betreffend compartiment t.o.v. de totale bovenstroomse afvoer berekend voor de (geo)hydrologische en chemische (diffuus en punt), fysische, hydraulische, morfologische en beheerstress.

De multiple stress berekening koppelt vervolgens de deelgebieden en segmenten aaneen van boven naar benedenstrooms, waarbij de toevoer naar een segment met een retentiefactor wordt vermenigvuldigd. Omdat de morfologie en het beheer en onderhoud segment specifiek zijn, wordt geen aandeel berekend. 


\section{Wegen van stressoren}

De stressoren staan in verband met de ecologische sleutelfactoren in het 5S-Model. Daarbij volgen ze ook de hiërarchie in de factoren en hoofdfactoren van dit model. Dat betekent automatisch dat stressoren niet allen even zwaar drukken op het aquatisch ecologisch systeem, maar dat de stress gewogen kan worden naar hiërarchische positie, watertype en bekende mate van effect. Wordt een dominant kritische waarde van een parameter overschreden, bijvoorbeeld een maximale temperatuur waarboven dieren of planten dood gaan, dan krijgt deze parameter een allesoverheersend gewicht. Systeemvoorwaarden zijn hierbij van groter belang dan chemische factoren. De ranges waarbinnen factoren geen stress opleveren en de waarden daarbuiten waar factoren minder of meer stress opleveren kunnen worden afgeleid van biologische informatie zoals de WEW-autecologielijst of andere beoordelingssystemen.

De stressklassen kunnen worden gewogen om tot een overall multiple stressscore per hoofdfactorgroep te komen.

Cumulatieve, synergistische, antagonistische en andere ongelijk verdeelde effecten zijn (nog) niet meegenomen, omdat deze effectinteracties nog vrijwel onbekend zijn. Daarom zijn interacties lineair meegenomen.

Stressoren werken ook niet langs de volledige ranges die mogelijk zouden kunnen voorkomen. Zo speelt zuurstof alleen een belangrijke rol voor de macrofauna bij gehalten lager dan $6 \mathrm{mg} / 1$ en wordt de rol dominant bij waarden lager dan 2 $\mathrm{mg} / \mathrm{l}$. Daarom zou het opnemen van grenswaarden in de stressklassen extra behulpzaam zijn (Tabel 15.1). Bij het bepalen van de stressklassen is hier ten dele wel al in voorzien, door de grenzen van de stressorklassen hierop af te stemmen (niet-lineair).

\section{TABEL 15.1}

Voorbeeld van grenswaarden.

\begin{tabular}{|l|l|}
\hline Parameter & $\begin{array}{l}\text { Grenswaarde (voorwaarde van meenemen in } \\
\text { weging) }\end{array}$ \\
\hline Temperatuur & $>16^{\circ} \mathrm{C}$ \\
\hline Beschaduwing & $<40 \%$ \\
\hline Stroomsnelheid & $<10 \mathrm{~cm} / \mathrm{s}$ \\
\hline Droogval & $<25$ jaar perm. \\
\hline Peilfluctuatie (pieken) & $>$ matig \\
\hline Structuren: & \\
\hline Natuurlijk lengteprofiel & $<40 \%$ \\
\hline Natuurlijk dwarsprofiel & $<40 \%$ \\
\hline Schoning/onderhoud & $>1 \mathrm{keer} / \mathrm{jaar}$ \\
\hline Stoffen: & \\
\hline Overstorten & Akker of int. grasl. \\
\hline Landgebruik & $>6 \mathrm{mg} / \mathrm{l}$ \\
\hline Zuurstof & $>200 \mathrm{mg} / \mathrm{L}$ \\
\hline Chloride & Aanwezig, $>\mathrm{NEC}$ \\
\hline $\begin{array}{l}\text { Zware metalen uit effluent } \\
\text { industrie }\end{array}$ & \\
\hline
\end{tabular}

Validatie van de berekeningen zal moeten uitwijzen in hoeverre gewichten correct zijn toegedeeld. 


\section{BIOTISCHE ANALYSE}

\subsection{Inleiding}

De biotische analyse heeft als doel overzichten op te stellen van de soorten die in de huidige situatie aanwezig zijn en die te verwachten zijn nadat knelpunten zijn aangepakt. Deze overzichten kunnen zijn watertype of traject specifiek worden opgesteld voor alle KRW-organismengroepen: vissen, macrofauna, water- en oeverplanten en algen.

Voorlopig is ervoor gekozen om alleen de indicatieve taxa per KRW-watertype te analyseren en niet de complete soortenlijst. KRW-indicatoren zijn bijvoorbeeld aangeduid als kenmerkende soort, positief dominante soort, doelsoort en gekoppeld aan bepaalde milieu- of habitatpreferenties, of gilden in het geval van vissen. De reden om niet voor alle taxa te kiezen is, naast de zeggingskracht van indicatoren over de toestand van het systeem, dat het juist deze taxa zijn die gewenst zijn wanneer ze ontbreken in bepaalde trajecten en daarmee beter gebruikt kunnen worden bij het opstellen van de doelen/streefbeelden.

In het voorbeeld van de Groote Molenbeek zijn de bovenlooptrajecten op dit moment geclassificeerd als KRW-watertype R4, subtype a "Permanente langzaam stromende laaglandbovenloop op zand met een laag verhang $(0,5-1 \mathrm{~m} / \mathrm{km})$ ” volgens de meest recente typologie (Van der Molen et al. 2018). Dit omvat de bovenloop van de Groote Molenbeek en alle zijbeken. De midden-benedenloop van de Groote Molenbeek is geclassificeerd als KRW-watertype R5 "Langzaam stromende middenloop/benedenloop op zand” en het meest benedenstroomse deel van de Groote Molenbeek als KRW-watertype R6 “Langzaam stromend riviertje op zand/klei”. Recent zijn nieuwe watertypen toegevoegd aan de KRW-typologie voor de R-typen; de moerasbeken (Van der Molen et al. 2018). Op basis van de eigenschappen van bepaalde trajecten in het stroomgebied van de Groote Molenbeek zouden deze - zeker wanneer beekdalbreed herstel zou worden uitgevoerd -ook kunnen worden geclassificeerd als moerasbeken, de KRW-watertypen Doorstroommoeras (R19, sommige bovenlooptrajecten) of Moerasbeek (R20), trajecten in de midden- en benedenloop van de Groote Molenbeek).

Voor de organismengroepen worden telkens drie stappen doorlopen.

1. Eerst wordt gekeken naar de gemeenschappen van deze organismegroepen die nu of in het recente verleden in het stroomgebied/waterbeheereenheid zijn gevonden (Welke soorten komen nu in het gebied voor?) en wordt de ecologische toestand waarin deze gemeenschappen zich bevinden bepaald (Wat zegt dit over de toestand van het systeem?). Deze analyse resultaten (multiple stress geïndiceerd door de organismen) worden ook vergeleken met de abiotische stress.

2. In de volgende stap wordt afgeleid wat er potentieel haalbaar is in het stroomgebied /waterbeheereenheid door te onderzoeken welke doelsoorten het gebied zouden kunnen koloniseren op de korte tot langere termijn en wordt verder gekeken naar de indicatiewaarden van deze soorten ten opzichte van de soorten die al in het gebied voorkomen (Wat kan hier? Welke zijn gewenste soorten en wat zijn hun milieueisen?).

3. Tenslotte geeft de vergelijking van de huidige toestand, met de gewenste soorten en hun milieu-eisen een indicatie van de aan te pakken knelpunten in het gebied (Wat knelt hier?).

\subsection{Macrofauna}

16.2.1 Wat is hier: de huidige macrofauna soortenpoule

Voor de analyse van de macrofauna wordt rondom ieder water in het waternetwerk een zone van $1 \mathrm{~km}$ breed geprojecteerd op een kaart: zone I (Figuur 16.1). De zone van $1 \mathrm{~km}$ is gekozen omdat daarbinnen de meeste verplaatsingen van macrofauna zich afspelen. Alle macrofauna-monsterpunten binnen deze zone I worden geselecteerd over alle jaren. Dit zijn de waterlopen en de geïsoleerde wateren. Juist deze laatste groep (stilstaande) wateren zijn bij beken relevant voor de moerasbeektypen en omgekeerd.

Daarna wordt gekeken op basis van de KRW-maatlatten voor alle aanwezige typen wateren welke positief dominante en kenmerkende taxa er in de monsters binnen deze zone I voorkomen. Deze taxa worden aangeduid vervolgens als de indicatoren en vormen de soortenpoule van het stroomgebied/waterbeheereenheid. 
Op basis van deze gegevens worden per locatie de aantallen indicatoren geteld. De locaties met de hoogste gemiddelde aantallen duiden voor het stroomgebied in onderzoek de potentiële biodiversiteitshotspots aan. Vanuit deze locaties kan het watersysteem in de toekomst worden ge(her)koloniseerd. Het aantreffen van specifieke indicatoren is niet alleen afhankelijk van de milieu-omstandigheden in het habitat maar ook van de trefkans. Indicatoren zijn vaak relatief zeldzaam waardoor de trefkans laag is; naarmate er vaker op een locatie bemonsterd wordt neemt de kans toe dat een taxon aangetroffen wordt. Daarom wordt niet gewerkt met het totale aantal maar met het gemiddeld aantal indicatoren per monster per locatie.

De huidige kwaliteitstoestand wordt m.b.v. de KRW-score per locatie en per tijdsperiode van bijvoorbeeld 10 of 20 jaar berekend. Hieruit kan worden afgeleid of er veranderingen in de tijd zijn opgetreden en waarom. Hierbij moet wel rekening gehouden worden met een verschil in berekening en gebruikte indicatoren in de verschillende maatlatten wanneer locaties in verschillende watertypen worden vergeleken; een directe vergelijking tussen punten van hetzelfde type geeft een betrouwbaarder beeld dan een vergelijking van de EKR tussen watertypen. Ook moet bij oudere data rekening worden gehouden met de taxonomie zoals op dat moment gebruikt werd, welke vertekend kan werken omdat in de loop van de tijd soorten beter kunnen worden herkend.

\section{FIGUUR 16.1}

Voorbeeld van de drie zones rondom de Groote Molenbeek. Zone I in (paars), zone II (5 km zone in roze) en zone III (15 km zone in groen). De zones geven de potentiele bronpopulaties van ontbrekende kenmerkende taxa en positief dominante taxa aan. De gekleurde stippen geven meetlocaties aan.

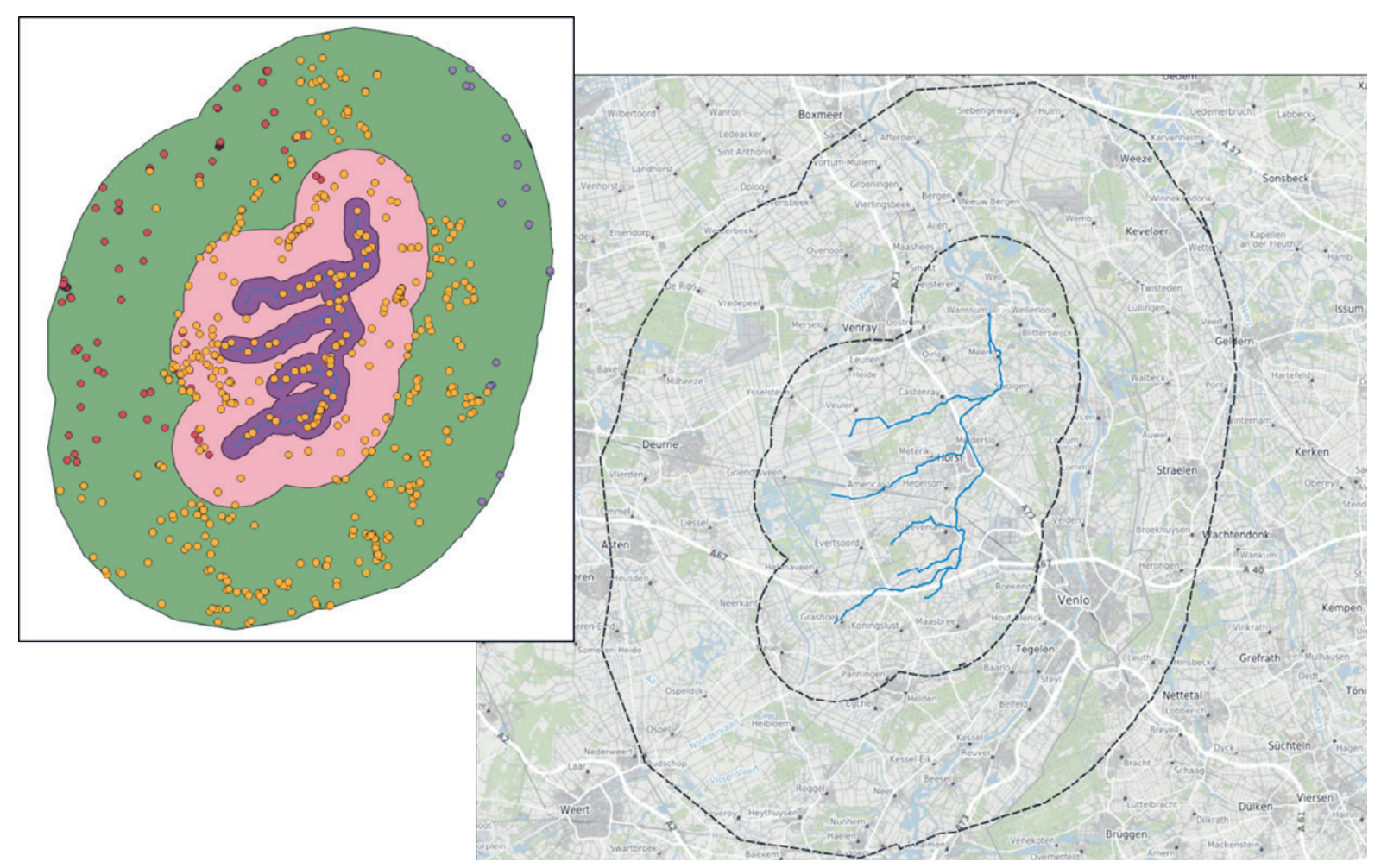

Om aan te geven wat de aanwezigheid van de kenmerkende en positief dominante taxa voor de verschillende watertypen zegt over de milieutoestand van de wateren in het stroomgebied/waterbeheereenheid worden een aantal sleutelfactoren geïdentificeerd op basis van de milieu- en habitatpreferenties van de macrofauna (Verberk et al. 2012). Omdat 
gebruik wordt gemaakt van kenmerkende en positief dominante taxa, worden alleen positieve indicaties gebruikt en geen negatieve indicaties zoals een preferentie voor ionenrijk, polysaproob of eutroof water. De indicatiewaarden van de taxa meters zijn bijvoorbeeld voor beken: temperatuur, habitatvoorkeur moeras, droogval, saprobie, trofie, stroming en zuurgraad. De indicatiewaarden in de lijst met de milieu- en habitatpreferenties zijn verdeeld over verschillende klassen volgens de zogenoemde 'fuzzy coding' techniek: afhankelijk van de habitat- en milieupreferentie van een taxon (meestal soort) zijn 10 punten verdeeld over de relevante klassen per parameter. Bijvoorbeeld een taxon met een voorkeur voor snelstromend water, maar die ook wel op plekken met matige stroming voorkomt krijgt de score: snelstromend = 8 punten, matig stromend = 2 punten, langzaam stromend = 0 punten etc. Voor de toestandsindicatie worden de relevante klassen per preferentie geselecteerd en waar nodig samengevoegd omdat het in de analyse alleen gaat om de 'echte' indicatoren en niet de taxa die onder verschillende omstandigheden kunnen voorkomen (ubiquisten). Om deze echte indicatoren te onderscheiden van de meer ubiquistische taxa wordt als criterium aangehouden dat tenminste de helft van het totale aantal punten in de geselecteerde klasse of klassen valt. Echter moet de score altijd hoger zijn dan het totaal dat verkregen wordt wanneer de puntenverdeling over de klassen gelijk is, waardoor in een aantal gevallen de drempelwaarde niet op 5 maar op 6 wordt vastgesteld. Vervolgens wordt gekeken op welke locaties deze indicatoren voorkomen in het stroomgebied, om zo de wateren of trajecten te identificeren met relatief goede milieu-omstandigheden. Hiervoor wordt per preferentie het gemiddelde aantal indicatoren per monster waargenomen sinds 2000 (de laatste 20 jaar) gebruikt. Deze trajecten zouden kunnen dienen als bron van kolonisten voor andere trajecten waar door maatregelen de omstandigheden verbeterd worden.

\subsubsection{Wat kan hier: de potentiële doelsoorten macrofauna}

Zoals gezegd spelen de meeste verplaatsingen van macrofauna zich binnen de zone van 1 kilometer ten opzichte van het water af, waarbij dieren zowel parallel aan een lijnvormig water of lateraal vanaf het water kunnen verplaatsen, bijvoorbeeld tussen een waterloop en aanliggende wateren (bijv. poelen en moerassen) en omgekeerd. Verplaatsingen in het water, vooral bij lijnvormige wateren, hebben een grote component in de stromingsrichting (in beken de zogenoemde drift). Verplaatsingen langs en vanaf een water vinden veelal vliegend plaats (vnl. waterinsecten), terwijl niet-insecten andere dispersiestrategieën kennen, zoals meeliften met andere organismen (mijten op insecten, bloedzuigers en slakken met watervogels etc.) of kruipen (bv. kreeften). De kans is het grootst dat de doelsoorten die al in het gebied aanwezig zijn op korte termijn wateren die door het nemen van maatregelen geschikt zijn geworden als leefgebied koloniseren. Op de iets langere termijn kunnen ook soorten die elders binnen het stroomgebied/waterbeheereenheid voorkomen koloniseren. Er zijn echter ook mogelijkheden voor kolonisatie van buiten het stroomgebied of de hydrologische eenheid, de slagingskans hiervan hangt van veel verschillende factoren af, zoals bijvoorbeeld het landschap en de barrières hierin, de grootte van bronpopulaties die kolonisten leveren en de weersomstandigheden.

Om te bepalen welke doelsoorten niet in het stroomgebied/waterbeheereenheid voorkomen maar er wel te verwachten zijn omdat ze in de aangrenzende gebieden voorkomen, worden allereerst alle monsterpunten binnen een zone van $5 \mathrm{~km}$ geselecteerd: zone II (Figuur 16.1). Vijf km is de afstand waarbinnen nog regelmatige dispersie plaatsvindt (Sundermann et al. 2011) en op basis waarvan we verwachten dat wanneer de juiste omstandigheden aanwezig zijn soorten op relatief korte tot iets langere termijn deze wateren weten te bereiken. Daarnaast worden ook de monsterpunten binnen een zone van 15 kilometer geselecteerd: zone III (Figuur 16.1). Succesvolle dispersie vanuit zone III is veel minder waarschijnlijk en de kans op kolonisatie door deze soorten is dan ook een lange-termijn-proces.

In de volgende stap wordt gekeken welke additionele kenmerkende taxa en positief dominante taxa die indicatief zijn voor de watertypen die in het stroomgebied/waterbeheereenheid voorkomen te vinden zijn binnen een straal van 1-5 kilometer en 5-15 kilometer. Dit zijn de doeltaxa die horen bij de streefbeelden op de korte tot langere termijn. Hierbij worden alleen taxa waargenomen vanaf 2000 meegeteld. Taxa van voor 2000 zijn waarschijnlijk verdwenen uit de regio. Met de indicaties voor watertype kan afgeleid worden in welk watertype ieder taxon thuishoort.

Welke van de theoretisch te verwachten taxa daadwerkelijk zouden kunnen voorkomen in het onderzoeksgebied wordt naast bereikbaarheid (dispersiemogelijkheden, grootte bronpopulaties) gebaseerd op de te realiseren verbeteringen in de 
abiotiek en habitatkwaliteit. Met een analyse van de milieu- en habitatpreferenties van de taxa die op dit moment niet nog niet in het te herstellen traject of water voorkomen wordt een beeld verkregen van de knelpunten en de kansen.

Waarom komt de ene indicatorsoort nu wel voor in het te herstellen water voor en de andere niet? Globaal gezien zijn er twee mogelijkheden, ten eerste dat de ontbrekende soorten het stroomgebied niet kunnen bereiken door de aanwezigheid van barrières of het ontbreken van kolonisten (zeer kleine populaties die daardoor weinig dispersie vertonen). Het vaststellen van barrières is lastig, omdat de kennis over de manier waarop en over welke afstanden aquatische organismen zich verspreiden zeer beperkt is. De afstand van enkele kilometers zou in theorie door de meeste soorten overbrugd moeten kunnen worden, maar in de praktijk lijkt deze laterale dispersie voor beken beperkt ten opzichte van de verplaatsingen binnen het stroomgebied (Westveer 2018). Waarschijnlijk is ook de populatiegrootte in deze relevant: vaak worden meer indicatieve taxa relatief weinig waargenomen. Alleen herintroducties of translocaties van soorten kunnen hier meer duidelijkheid in scheppen, zoals bijvoorbeeld in 2014 op de Veluwe gebeurd is (Verdonschot et al. 2015).

Ten tweede speelt habitatgeschiktheid een cruciale rol; wanneer een soort het onderzoeksgebied bereikt moet er wel een geschikte plek aanwezig zijn waar deze zich kan vestigen. Echter, het vaststellen of de habitat geschikt is voor een soort vraagt of specifieke kennis van alle eisen die de soort stelt in termen van abiotische (fysisch-chemische, morfologische, hydrologische) en biotische (predatie, competitie) omstandigheden op de ruimtelijke en tijdschaal relevant voor alle levensstadia van de soort. Wat dit aspect betreft zijn er nog veel kennishiaten. Tijdens het onderzoek aan de Groote Molenbeek bleek al dat een groot deel van de kenmerkende en positief dominante taxa geen indicator is voor een van de onderzochte milieu- en habitatpreferenties. Deze soorten stellen dus andere eisen aan het milieu die niet bekend zijn maar wel even relevant, bijvoorbeeld met betrekking tot de hydrologie, morfologie, kwaliteit van het beekdal enz. Zijn er wel preferenties bekend, dan geeft dit nog slechts globale informatie over de eisen die de soorten stellen. Om vast te stellen aan welke randvoorwaarden nu niet wordt voldaan waardoor bepaalde soorten niet voorkomen zouden veel meer preferenties en traits moeten worden bekeken (en in combinatie met elkaar) om dit beter in beeld te brengen. Echter, voor veel soorten is deze informatie momenteel niet beschikbaar. Wel kan worden gekeken welke soorten vaak samen voorkomen, waaruit kan worden afgeleid dat deze soorten vergelijkbare eisen stellen aan de habitat.

\subsection{Vissen}

16.3.1 Wat is hier: de huidige vissen soortenpoule

Alle data uit bevissingen, binnen en buiten de reguliere waterschapsmonitoring, verricht in het gehele stroomgebied/waterbeheereenheid worden verzameld. Dan worden de soorten met een indicatieve waarde geselecteerd. Deze indicatieve waarde wordt afgeleid van de gilden waartoe de soorten behoren. In de analyse voor de Groote Molenbeek is bijvoorbeeld gebruik gemaakt van de kenmerken: rheofilie (stromingsminnendheid incl. zuurstofrijk water), migratie potentieel (indicatief voor een goede connectiviteit) en plantminnendheid (indicatief voor luwe zones in de beek met waterplantenvegetaties).

Ook voor vissen kunnen op basis van aantallen soorten biodiversiteitshotspots worden geduid. Hierbij moet altijd rekening worden gehouden met de veel grotere 'home range' van vissen. Door deze grote verplaatsingen in de ruimte zegt een locatie weinig over de toestand. Verschillen met het verleden geven de veranderingen in de tijd weer.

Vervolgens wordt op basis van de vissamenstelling de KRW-kwaliteitsscore berekend. Voor beken is de vissenmaatlat opgebouwd uit de deelmaatlatten soortenrijkdom en abundantie. Deze gebruiken informatie van verschillende ecologische gilden die gekoppeld zijn aan de toestand van het systeem.

\subsubsection{Wat kan hier: de potentiële doelsoorten vissen}

Bij het onderzoek van de mogelijkheden voor vissoorten in de toekomst spelen drie componenten een rol: 1.) het versterken van de populaties van de al aanwezige soorten, 2 .) het stimuleren van vestiging van incidentele/zwervende soorten en 3.) het stimuleren van vestiging van ontbrekende soorten. Het versterken van populaties en het stimuleren van incidenteel voorkomende soorten wordt gebaseerd op de milieu-eisen van de betreffende soorten. 
Ten opzichte van bijvoorbeeld de macrofauna-indicatoren is er zeer veel bekend over de milieu- en habitatpreferenties van vissen met betrekking tot fysisch-chemische waterkwaliteit en de eisen die gesteld worden aan de morfologie en hydrologie. De schaal (in ruimte en tijd) waarop vissen van het landschap gebruik maken is echter groot, wat betekent dat voor de meeste soorten waterlichaam en vaak zelfs stroomgebied overstijgend gekeken moet worden naar deze eisen. Een zonering is voor vissen daarom niet mogelijk. Veel beter kan gekeken worden naar de verspreidingscapaciteit en milieu-eisen van de individuele soorten en om per soort de kansen op terugkeer af te leiden. Voor een specifieke habitatanalyse voor de verschillende levensstadia van een deel van de beekvissoorten wordt verwezen naar de beekvissensleutel (Verdonschot \& Verdonschot 2012). Een dergelijke sleutel zou ook voor stilstaande wateren kunnen worden ontwikkeld.

Wat betreft ontbrekende soorten worden eveneens de beperkingen in het stroomgebied/waterbeheereenheid onderzocht, echter wordt ook gekeken naar het leefgebied van de bronpopulaties en de connectiviteit tussen dit leefgebied en het onderzoeksgebied. Naast de milieu- en habitateisen is door het grote ruimtegebruik van vissen de connectiviteit binnen en tussen stroomgebieden/hydrologische eenheden een cruciaal aspect bij het bepalen van de kansen voor soorten. Hierbij spelen de aanwezigheid van barrières en vispassages een grote rol. Barrières betreffen niet alleen stuwen maar ook grote ongeschikt leefgebieden zoals overkluizingen, havens, grote vijvers of stagnante stuwpanden in een beek en daarnaast zwaar vervuilde trajecten.

\subsection{Macrofyten}

16.4. Wat is hier: de huidige macrofyten soortenpoule

Om een beeld te krijgen van de vegetatie worden waterschapsdata (opnamen biologische monitoring, o.a. KRW-meetpunten) en aanvullende vegetatiegegevens uit de Nationale Databank Flora en Fauna (NDFF) gebruikt. Het gebruik van deze combinatie is noodzakelijk om een volledig beeld te krijgen van de aanwezigheid van doelsoorten, omdat de waterschapsmonitoring vaak niet toereikend is door de beperkte gebiedsdekking en wijze van inventariseren (KRW-opnamen versus planteninventarisaties van bijv. terreinbeherende organisaties, pgo's) en de locaties die bezocht zijn (vaste meetpunten langs grotere wateren versus specifiek op de 'beste' of bekende plekken zoeken naar soorten). De waterschapsdata wordt wel als uitgangspunt gebruikt voor de analyses om de aanpak vergelijkbaar te houden met de andere organismegroepen. Omdat gegevens vaak vlakopnamen betreffen is het noodzakelijk deze op te splitsen in drie groepen: 1.) waarnemingen in het water zelf (open water en directe natte oeverzone), 2.) waarnemingen in de directe omgeving, zoals een beekdal of oeverbegeleidende zone, en 3.) waarnemingen in de afwaterings- en zijstroomgebieden die op het te onderzoeken water afwateren. De eerste groep wordt gebruikt voor de analyse van de huidige toestand, de beide andere gegevenssets worden gebruikt voor de analyse van de mogelijkheden in de toekomst. Daarnaast kunnen, zoals bij beide vorige organismengroepen, tijdsperioden worden gesplitst, bijvoorbeeld de periode voor het jaar 2000 en de periode vanaf 2000.

Vervolgens wordt een selectie gemaakt van de doelsoorten gebaseerd op de KRW-indicatoren en eventueel aangevuld met provinciale doelsoorten. Voor de indicerende plantensoorten worden een aantal milieueisen gebruikt (CBS-lijst 1987, Verdonschot et al. 2003). Het gaat om tolerantie voor een hoge voedselrijkdom, minimale stroomsnelheid, lage zuurgraad en maximale beschaduwing. Typische beekplanten bijvoorbeeld prefereren een lage voedselrijkdom, stroming, een zwak zure tot neutrale zuurgraad en relatief veel beschaduwing.

De ecologische kwaliteit wordt berekend met behulp van de deelmaatlat soortensamenstelling waterplanten. Daarnaast wordt het gemiddeld aantal positieve indicatoren op de meetlocaties berekend en kunnen opnieuw biodiversiteitshotspots worden geïdentificeerd.

\subsubsection{Wat kan hier: de potentiële doelsoorten macrofyten}

Om te bepalen welke indicatieve plantensoorten nu niet (meer) in de wateren in het onderzoeksgebied voorkomen, maar wel te verwachten zijn wanneer de omstandigheden geschikt zijn, wordt gebruik gemaakt van de vegetatiegegevens uit met name uit de NDFF-database. Deze database omvat de overige wateren en natte plekken in een gebied, waaronder poelen en plassen, sloten, greppels, broekbossen, moerassen en veengebieden. Hierbij nemen we aan dat deze plekken als belangrijkste bron kunnen dienen voor de verspreiding van de indicatorsoorten en waar vandaan op relatief korte termijn 
door de korte afstand de soorten te verwachten zijn. Of planten zich makkelijk binnen het onderzoeksgebied kunnen verspreiden vanuit de overige wateren is overigens onduidelijk.

Kolonisatieonderzoek in beekherstelprojecten heeft laten zien dat vooral kolonisatie in stroomafwaartse richting door de al dominante plantensoorten lijkt plaats te vinden (Fraaije 2016). Planten die zich via het water verspreiden, via plantfragmenten en/of drijvende zaden, verspreiden zich alleen in stroomafwaartse richting, waardoor bovenstrooms gelegen trajecten moeilijk gekoloniseerd kunnen worden. Verspreiding vanuit geïsoleerde wateren is voor dit type planten niet mogelijk. Alleen planten met zaden die via de lucht of meeliftend met dieren of maaimaterieel verplaatst kunnen worden zijn in staat zich in meerdere richtingen binnen het stroomgebied te verplaatsen. Hier staat wel tegenover dat plantenzaden zich in de zaadbank in de ondergrond kunnen bevinden (afkomstig van historische vegetaties, sommige soorten hebben zaden die lang kiemkrachtig blijven) en via deze weg alsnog op plekken kunnen opduiken.

Om in beeld te krijgen welke eisen de ontbrekende indicatorsoorten stellen wordt een opsomming gemaakt van de milieu-indicaties van deze soorten. 


\section{VISUALISEREN VAN MULTIPLE STRESS EN DUIDEN VAN KNELPUNTEN}

De scores uit de abiotische analyse van multiple stress per traject kunnen ruimtelijk worden weergegeven op een kaart (Figuur 17.1). De EKR-scores op basis van de verschillende biologische groepen (macrofauna, planten, vissen) kunnen eveneens op kaart worden aangegeven. Beide kaarten kunnen dan, als validatiestap, worden vergeleken om te zien of de resultaten passend zijn. Voor een meer gedetailleerde validatie van de (individuele) stressoren, of groepen daarvan, wordt gebruik gemaakt van de biotiek, bijvoorbeeld door de stressorwaarden te vergelijken met de indicaties van de indicatieve soorten of soortgroepen.

Met de kaart met multiple stress-scores kunnen de specifieke knelpunten worden gevonden door de berekening achter de stressscores per segment of traject te bekijken en de oorsprong van de stress-score te identificeren. Deze oorzaken kunnen ook visueel inzichtelijk worden gemaakt door de afzonderlijke bijdragen van stressoren en compartimenten ruimtelijk weer te geven.

\section{FIGUUR 17.1}

Voorbeeld van de projectie van de macrofauna EKR-score (links) en de aantallen kenmerkende en positief dominante macrofauna (rechts) geprojecteerd op de kaart met de gestandaardiseerde stressscores.
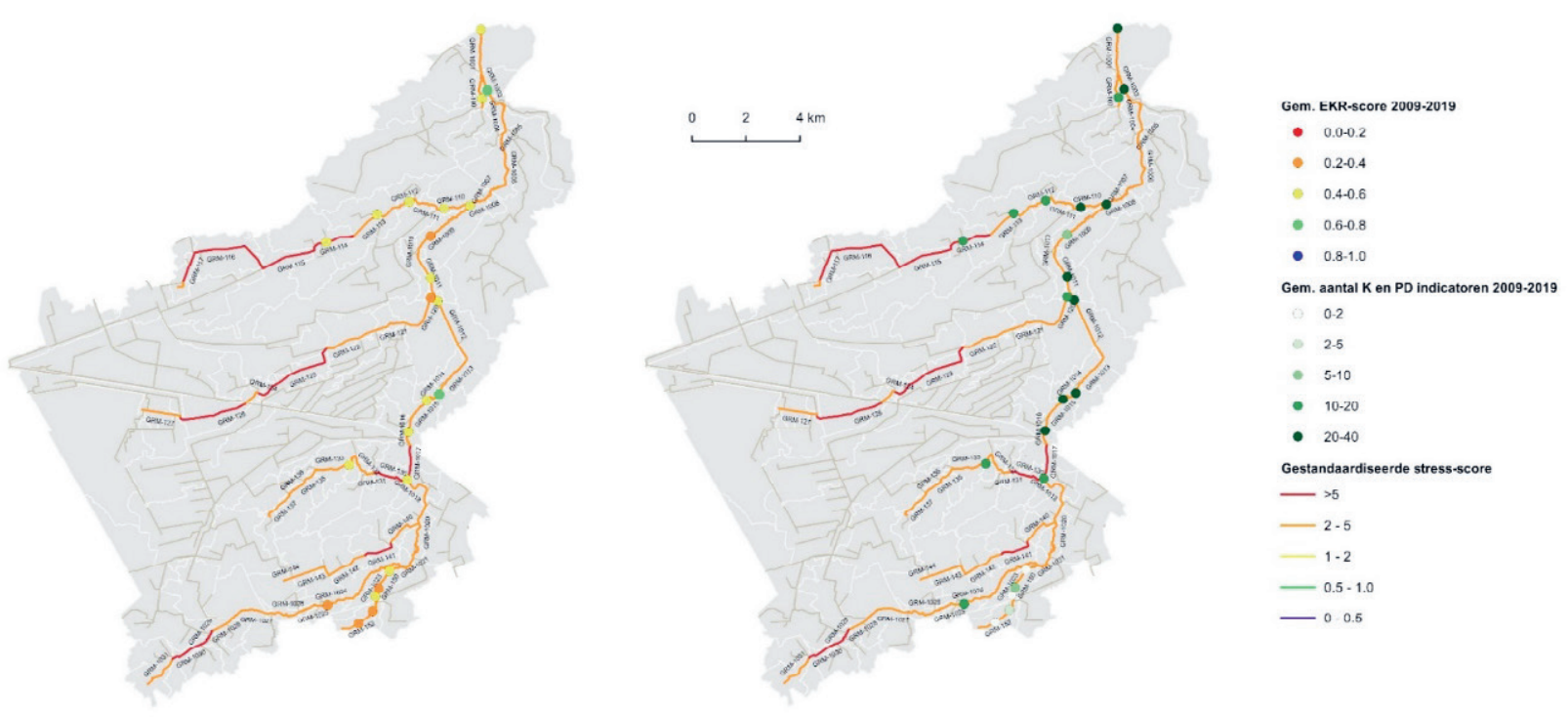


\section{HET KIEZEN VAN MAATREGELPAKKETTEN (SCENARIO-ANALYSE)}

\subsection{Milieu-omstandigheden}

De methode voor het in kaart brengen van multiple stress in de huidige situatie kan ook worden gebruikt om de effecten van maatregelscenario's in beeld te brengen. De scenario's kunnen de ideale situatie, enkele stroomgebiedsbrede of waterbeheereenheid dekkende maatregelen of combinaties van maatregelen bevatten (zie voorbeeld in Tabel 18.1).

De SESA-modelaanpassingen worden gedaan in de scores voor de stressoren die door ieder van de geselecteerde maatregelen wijzigen en gebieden die door de betreffende maatregel(en) worden beïnvloed. Er wordt bij de berekeningen uitgegaan van een optimale effectiviteit op het moment van de effectbepaling.

Voor elk scenario kan vervolgens de berekende ruimtelijke verdeling van multiple stressorscores worden weergegeven en vergeleken met de huidige situatie. De klassegrenzen geven daarbij de relatieve intensiteit van de stress en kunnen worden uitgedrukt als een gestandaardiseerde "EKR"-score.

\section{TABEL 18.1}

Een aantal voorbeelden van maatregelscenario's met hun locatie in het stroomgebied of schaalniveau en aanpassingen van parameters binnen het model.

\begin{tabular}{|c|c|c|c|}
\hline & Scenario & Schaal/locatie & Modelaanpassing \\
\hline 1 & Volledig circulaire landbouw met bosstroken langs de beek & Gehele stroomgebied & $\begin{array}{l}\text { Landgebruik zijstroomgebied en } \\
\text { buffer, beschaduwing, morfologie } \\
\text { en beheer }\end{array}$ \\
\hline 2 & Beschaduwing natuurbeken door aanleg bosstroken & Bufferzones & $\begin{array}{l}\text { Landgebruik buffer, beschaduwing, } \\
\text { morfologie, beheer }\end{array}$ \\
\hline 3 & $\begin{array}{l}\text { Piekafvoer-demping d.m.v. ontwikkeling } \\
\text { doorstroommoerassen in de bovenlopen }\end{array}$ & Zijstroomgebiedjes & $\begin{array}{l}\text { Landgebruik zijstroomgebied, } \\
\text { hydrologie }\end{array}$ \\
\hline 4 & $\begin{array}{l}\text { Periodieke inundatie beekdal als gevolg van aanpassen } \\
\text { dwarsprofiel }\end{array}$ & Bufferzones & $\begin{array}{l}\text { Landgebruik buffer, hydrologie, } \\
\text { morfologie }\end{array}$ \\
\hline 5 & $\begin{array}{l}\text { Water langer vasthouden op landbouwpercelen en in } \\
\text { bosgebieden }\end{array}$ & Gehele stroomgebied & $\begin{array}{l}\text { Landgebruik zijstroomgebied en } \\
\text { buffer, hydrologie }\end{array}$ \\
\hline 6 & Saneren puntbronnen & Gehele stroomgebied & $\begin{array}{l}\text { Puntbronnen binnen } \\
\text { zijstroomgebieden en buffers }\end{array}$ \\
\hline 7 & Verbeterde landbouwtechniek (aanzet tot circulaire landbouw) & Gehele stroomgebied & $\begin{array}{l}\text { Landgebruik zijstroomgebied en } \\
\text { buffer }\end{array}$ \\
\hline 8 & $\begin{array}{l}\text { Functieverandering aanliggende percelen natuurbeken van } \\
\text { landbouw naar natuurgrasland }\end{array}$ & Bufferzones & Landgebruik buffer \\
\hline 9 & $\begin{array}{l}\text { Functiewijziging agrarische percelen; sterk belastende teelten } \\
\text { worden vervangen door minder belastende teelten }\end{array}$ & Bufferzones & Landgebruik buffer \\
\hline
\end{tabular}

\subsection{Visualisatie scenario's}

Per regio (bovenloop en midden/benedenloop) en per kwaliteitsklasse (1-5) wordt tenslotte een realistisch streefbeeld omschreven. Dit kan visueel worden gedaan, waarmee de inrichting van de beek en het beekdal in beelden worden weergegeven en bijvoorbeeld enkele icoonsoorten of groepen karakteristieke soorten worden benoemd (Figuur 18.1). 


\section{FIGUUR 18.1}

Vereenvoudigd voorbeeld van een schematische weergave van een biotisch streefbeeld voor de beeksegmenten van de natuurbeken in het stroomgebied van de Groote Molenbeek. Beektype en kwaliteit stellen de randvoorwaarden, de kans op verschijnen wordt vooral bepaald door afstand tot bronpopulaties en de populatiegrootte van doelsoorten.

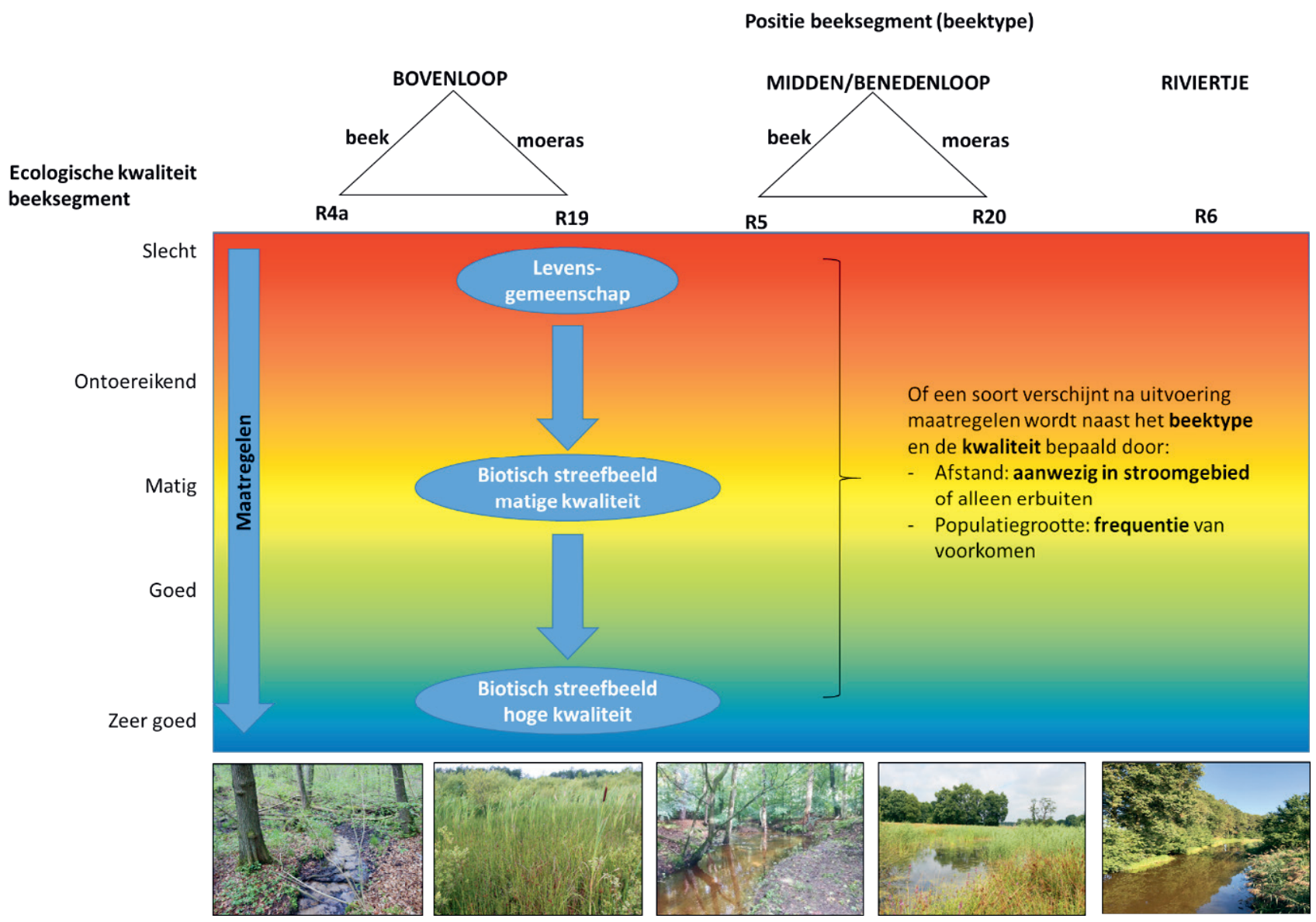




\section{LITERATUUR}

Aarts, H. P. A. (2001). Natuurlijke levensgemeenschappen van de Nederlandse binnenwateren deel 11, Rijkskanalen. ECLNV rapport AS-11.

Alahuhta, J. (2015). Geographic patterns of lake macrophyte communities and species richness at regional scale. Journal of Vegetation Science, 26(3), 564-575.

Allan, D., Erickson, D., \& Fay, J. (1997). The influence of catchment land use on stream integrity across multiple spatial scales. Freshwater biology, 37(1), 149-161.

Allan, J. \& Johnson, L. (1997). Catchment scale analysis of aquatic ecosystems. Freshwater Biology, 37(1), $107-111$.

Allan, J. D. \& Castillo, M. M. (2007). Stream ecology: structure and function of running waters. Springer Science \& Business Media.

Allan, T. F. H., \& Starr, T. B. (1982). Hierarchy. Perspectives for ecological complexity, Chicago.

Anderson, N. J. (2014). Landscape disturbance and lake response: temporal and spatial perspectives. Freshwater Reviews, 7(2), 77-120.

Armitage P.D., Moss D., Wright J.F., M.T. Furse (1983). The performance of a new biological water quality score system based on macroinvertebrates over a wide range of unpolluted running-water sites Water Research 17: 333-347.

Arts, G. H. (2000). Natuurlijke levensgemeenschappen van de Nederlandse binnenwateren: deel 13: Vennen: achtergronddocument bij het Handboek natuurdoeltypen in Nederland.

Austin, M. P. (1980). Searching for a model for use in vegetation analysis. Vegetatio 42:11-21.

Austin, M. P., \& Smith, T. M. (1990). A new model for the continuum concept. In Progress in theoretical vegetation science (pp. 35-47). Springer, Dordrecht.

Bailey R.C., Norris R.H. \& T.B. Reynoldson (2004). Bioassessment of freshwater ecosystems. Using the reference condition approach. Springer Science + Business Media, Inc. 170 pp.

Bakker, T.W.M., Klijn, J.A. \& Van Zadelhoff, F.J. (1981). Nederlandse kustduinen. Landschapsecologie. Pudoc, Wageningen.

Barbour M.T., Gerritsen J., Snyder B.D. \& J.B. Stribling (1999). Rapid bioassessment protocols for use in streams and wadeable rivers: periphyton, benthic macroinvertebrates, and fish. 2th edition. EPA 841-B-99-002. U.S. Environmental Protection Agency, Office of Water, Washington, D.C.

Barrat-Segretain, M. H. (1996). Strategies of reproduction, dispersion, and competition in river plants: a review. Vegetatio, 123(1), 13-37.

Beers P.W.M. van \& Verdonschot P.F.M. (2000): Natuurlijke levensgemeenschappen van de Nederlandse binnenwateren. Deel 4, Brakke binnenwateren. Achtergronddocument bij het 'Handboek Natuurdoeltypen in Nederland'. Rapport AS04, EC-LNV. Alterra, Wageningen. 80 pp.

Biggs, J., Corfield, A., Walker, D., Whitfield, M., \& Williams, P. (1994). New approaches to the management of ponds. British Wildlife, 5(5), 273-287.

Birk, S., Chapman, D., Carvalho, L., Spears, B. M., Andersen, H. E., Argillier, C., ... \& Bondar-Kunze, E. (2020). Impacts of multiple stressors on freshwater biota across spatial scales and ecosystems. Nature Ecology \& Evolution, 1-8.

Blocksom K.A., Kurtenbach J.P., Klemm D.J., Fulk F.A. \& S.M. Cormier (2002). Development and evaluation of the lake macroinvertebrate integrity index (LMII) for New Yersey lakes and reservoirs. Environmental Monitoring and Assessment 77: 311-333.

Bloemendaal F. \& Roelofs, J. G. M. (1988). Waterplanten en waterkwaliteit. F. H. J. L. Bloemendaal (Ed.). Utrecht: Koninklijke Nederlandse Natuurhistorische Vereniging.

Bonada, N., Prat, N., Resh, V. H., \& Statzner, B. (2006). Developments in aquatic insect biomonitoring: a comparative analysis of recent approaches. Annu. Rev. Entomol., 51, 495-523.

Borger G.J. 1992. Draining - digging - dredging; the creation of a new landscape in the peat areas of the low countries. In: Verhoeven J.T.A. (red.). Fens and bogs in the Netherlands: vegetation, history, nutrient dynamics and conservation. Kluwer, Dordrecht.Lamers L., Klinge M. \& Verhoeven J. 2001. OBN Preadvies laagveenwateren. Op weg naar systeemherstel. Expertisecentrum LNV, Wageningen. 
Briske, D.D., Fuhlendorf, S.D. \& Smeins, F.E., 2006. A unified framework for assessment and application of ecological thresholds. Rangeland Ecology and Management 59: 225-236.

Byers, J. E., Cuddington, K., Jones, C. G., Talley, T. S., Hastings, A., Lambrinos, J. G., Crooks J. A. \& Wilson, W. G. (2006). Using ecosystem engineers to restore ecological systems. Trends in ecology \& evolution, 21(9), 493-500.

Cairns Jr. J., McCormick P.V. \& B.R. Niederlehner (1993). A proposed framework for developing indicators of ecosystem health. Hydrobiologia 263: 1-44.

Cardinale, B. J., Palmer, M. A., \& Collins, S. L. (2002). Species diversity enhances ecosystem functioning through interspecific facilitation. Nature, 415(6870), 426-429.

Carlisle D.M. \& C.P. Hawkins (2008). Land use and the structure of western US stream invertebrate assemblages: predictive models and ecological traits. Journal of the North American Benthological Society 27(4): 986-999.

Carpenter, S. R. (1981). Submersed vegetation: an internal factor in lake ecosystem succession. The American Naturalist, 118(3), 372-383.

Carpenter, S. R. (Ed.). (2012). Complex interactions in lake communities. Springer Science \& Business Media.

Centraal Bureau voor de Statistiek, 1987. Botanisch Basisregister. Voorburg/Heerlen

Charvet S., Statzner B., Usseglio-Polatera P. \& B. Dumont (2000). Traits of benthic macroinvertebrates in semi-natural French streams: an initial application to biomonitoring in Europe. Freshwater Biology 43(2): 277-296.

Chave, J. (2013). The problem of pattern and scale in ecology: what have we learned in 20 years?. Ecology letters, 16, 4-16.

Christensen, M. R., Graham, M. D., Vinebrooke, R. D., Findlay, D. L., Paterson, M. J., \& Turner, M. A. (2006). Multiple anthropogenic stressors cause ecological surprises in boreal lakes. Global Change Biology, 12(12), 2316-2322.

Clements, W. H., Hickey, C. W., \& Kidd, K. A. (2012). How do aquatic communities respond to contaminants? It depends on the ecological context. Environmental Toxicology and Chemistry, 31(9), 1932-1940.

CUWVO (1986). Ecologische kwaliteitsdoelstellingen voor Nederlandse oppervlakterwateren. Coördinatiecommissie Uitvoering Wet Verontreiniging Oppervlaktewateren. 205 p.

Davies S.P. \& S.K. Jackson (2006). The biological condition gradient: a descriptive model for interpreting change in aquatic ecosystems. Ecological Applications 16(4): 1251-1266.

de Brouwer, J. H. F. (2020). Spatiotemporal heterogeneity in lowland streams: A benthic macroinvertebrate perspective. PhD-thesis, University of Amsterdam, 189 pp.

de Vries, J., Kraak, M. H., Verdonschot, R. C., \& Verdonschot, P. F. (2019). Quantifying cumulative stress acting on macroinvertebrate assemblages in lowland streams. Science of the Total Environment, 694, 133630.

Delcourt, H. R., Delcourt, P. A., \& Webb III, T. (1982). Dynamic plant ecology: the spectrum of vegetational change in space and time. Quaternary Science Reviews, 1(3), 153-175.

dos Reis Oliveira, P. C., Kraak, M. H., van der Geest, H. G., Naranjo, S., \& Verdonschot, P. F. (2018). Sediment composition mediated land use effects on lowland streams ecosystems. Science of the Total Environment, 631, 459-468.

Dufour F.C. 1998. Grondwater in Nederland. Onzichtbaar water waarop wij lopen. Geologie van Nederland, deel 3. TNONITG, Delft.

Duigan, C., Kovach, W., \& Palmer, M. (2007). Vegetation communities of British lakes: a revised classification scheme for conservation. Aquatic Conservation: Marine and Freshwater Ecosystems, 17(2), 147-173.

European Environment Agency (1995). Europe’s Environment: The Dobris Assessment. Earthscan, London. European Environment Agency (EEA).

Farnsworth, K. D., Albantakis, L., \& Caruso, T. (2017). Unifying concepts of biological function from molecules to ecosystems. Oikos, 126(10), 1367-1376.

Feld, C.K., Birk, S., Bradley, D.C., Hering, D., Kail, J., Marzin, A., Melcher, A., Nemitz, D., Pedersen, M.L., Pletterbauer, F., Pont, D., Verdonschot, P.F.M. \& Friberg, N. (2011). From Natural to Degraded Rivers and Back Again: A Test of Restoration Ecology Theory and Practice. Advances in Ecological Research 44: 120-209.

Flather C.H. \& C.H. Sieg (2007). Species rarity: definition, causes, and classification. p 40-66. In: Raphael MG \& R Molina (eds.) Conservation of rare or little-known species: biological, social, and economic considerations. Island Press. 375 pp.

Fraterrigo, J. M., \& Downing, J. A. (2008). The influence of land use on lake nutrients varies with watershed transport capacity. Ecosystems, 11(7), 1021-1034. 
Frissell, C. A., Liss, W. J., Warren, C. E., \& Hurley, M. D. (1986). A hierarchical framework for stream habitat classification: viewing streams in a watershed context. Environmental management, 10(2), 199-214.

Gayraud S., Statzner B., Bady P., Haybachp A., Schöll F., Usseglio-Polatera P. \& M. Bacchi (2003). Invertebrate traits for the biomonitoring of large Europeran rivers: an initial assessment of alternative metrics. Freshwater Biology 48: 20452064.

Gotelli N.J. (2008). A primer of Ecology. 4th edition. Sinauer Associates, Inc. 291 pp.

Groenendijk, P., van Boekel, E., Renaud, L., \& Greijdanus, A. (2017). Landbouw en de KRW-opgave voor nutriënten in regionale wateren. Water Matters: Kenniskatern voor Waterprofessionals-Dutch edition, (december), 24-27.

Halpern, B. S., Silliman, B. R., Olden, J. D., Bruno, J. P., \& Bertness, M. D. (2007). Incorporating positive interactions in aquatic restoration and conservation. Frontiers in Ecology and the Environment, 5(3), 153-160.

Hautier, Y., Niklaus, P. A., \& Hector, A. (2009). Competition for light causes plant biodiversity loss after eutrophication. Science, 324(5927), 636-638.

Hering D., Feld C.K., Moog O. \& T. Ofenböck (2006a). Cook book for the development of a multimetric index for biological condition of aquatic ecosystems: experiences from the European AQEM and STAR projects and related initiatives. Hydrobiologia 566: 311-324.

Hering D., R.K. Johnson, S. Kramm, S. Schmutz, K. Szoszkiewicz \& P.F.M. Verdonschot (2006b) Assessment of European streams with diatoms, macrophytes, macroinvertebrates and fish: a comparative metric-based analysis of organism response to stress. Freshwater Biology 51: 1757-1785.

Hering D., Verdonschot P.F.M., Moog O. \& L. Sandin (eds.) (2004) Integrated assessment of running waters in Europe. Developments in hydrobiology 175. Kluwer Academic Publishers 379 pp.

Higler, B. (2000). Natuurlijke levensgemeenschappen van de Nederlandse binnenwateren deel 7, laagveenwateren; achtergronddocument bij het'Handboek Natuurdoeltypen in Nederland' (No. AS-07). EC-LNV.

Holmes, N. T. H., Boon, P. J., \& Rowell, T. A. (1998). A revised classification system for British rivers based on their aquatic plant communities. Aquatic Conservation: marine and freshwater ecosystems, 8(4), 555-578.

Holomuzki, J. R., Feminella, J. W., \& Power, M. E. (2010). Biotic interactions in freshwater benthic habitats. Journal of the North American Benthological Society, 29(1), 220-244.

Hussain, Q. A., \& Pandit, A. K. (2012). Macroinvertebrates in streams: A review of some ecological factors. International Journal of Fisheries and Aquaculture, 4(7), 114-123.

Hynes H.B.N. (1975). Edgardo Baldi Memorial Lecture: The stream and its valley.Verhandlungender110-127.Khorram S. \& Cheshire H.M. (1985) Remote sensing of Internationalen Vereinigung fur Theoretische und Angewandte Limnologie,19, 1-15.

Hynes, H. B. N. (1975). The stream and its valley: With 4 figures and 2 tables in the text. Internationale Vereinigung für theoretische und angewandte Limnologie: Verhandlungen, 19(1), 1-15.

Jaarsma N.G. \& Verdonschot P.F.M. (2000): Biodiversiteit van wateren in Flevoland. Wageningen, Alterra, (2000): Alterra rapport 034, Wageningen. $105 \mathrm{pp}$.

Jaarsma N.G. \& Verdonschot P.F.M. (2000): Natuurlijke levensgemeenschappen van de Nederlandse binnenwateren. Deel 5. Poelen. Achtergronddocument bij het 'Handboek Natuurdoeltypen in Nederland'. Rapport AS-05, EC-LNV. Alterra, Wageningen. 59 pp.

Jaarsma N.G. \& Verdonschot P.F.M. (2000): Natuurlijke levensgemeenschappen van de Nederlandse binnenwateren. Deel 8. Wingaten. Achtergronddocument bij het 'Handboek Natuurdoeltypen in Nederland'. Rapport AS-08, EC-LNV. Alterra, Wageningen. 63 pp.

Jaarsma N.G. \& Verdonschot P.F.M. (2000): Natuurlijke levensgemeenschappen van de Nederlandse binnenwateren. Deel 10. Regionale kanalen. Achtergronddocument bij het 'Handboek Natuurdoeltypen in Nederland'. Rapport AS-10, ECLNV. Alterra, Wageningen. 59 pp.

Jaarsma N.G., Verdonschot P.F.M., Nijboer R.C. \& Hoorn M.W. van den, 2001. Ecologische streefbeelden voor stromende wateren Veluwe \& Vallei. Wageningen, Alterra, Research Instituut voor de Groene Ruimte. Alterra rapport 377, Wageningen. $108 \mathrm{pp}$.

Jackson, M. C., Loewen, C. J., Vinebrooke, R. D., \& Chimimba, C. T. (2016). Net effects of multiple stressors in freshwater ecosystems: a meta analysis. Global change biology, 22(1), 180-189. 
Jacobsen, D., Schultz, R., \& Encalada, A. (1997). Structure and diversity of stream invertebrate assemblages: the influence of temperature with altitude and latitude. Freshwater Biology, 38(2), 247-261.

Jalink M.H., Grijpstra J. \& Zuidhoff A.C. 2003. Hydro-ecologische systeemtypen met natte schraallanden in Pleistoceen Nederland. Expertisecentrum LNV, Ede.

Janssen S.N., Verdonschot P.F.M. \& Arts G.H.P. (1998): Typologie van zoete duinwateren gebaseerd op macrofauna, macrofyten, diatomeeën en milieuvariabelen. IBN rapport 390. 200 pp.

Jax, K. (2005). Function and "functioning” in ecology: what does it mean?. Oikos, 111(3), 641-648.

Jeppesen, E., J. P. Jensen, M. Sondergaard, T. Lauridsen, \& F. Landkildehus (2000). Trophic structure, species richness, and biodiversity in Danish lakes: changes along a phosphorus gradient. Freshwater Biology 45: 201- 218.

Johnson, L. \& Gage, S. (1997). Landscape approaches to the analysis of aquatic ecosystems. Freshwater Biology, 37(1), 113132.

Johnson, R. K., Furse, M. T., Hering, D., \& Sandin, L. (2007). Ecological relationships between stream communities and spatial scale: implications for designing catchment level monitoring programmes. Freshwater Biology, 52(5), 939-958.

Karr J.R. \& E.W. Chu (1999). Restoring life in running waters. Better biological monitoring. Island Press. 206 pp.

Keizer-Vlek, H. E., Verdonschot, P. F. M., \& Goedhart, P. W. (2009). Monitoring van aquatische natuur: KRW monitoring voor natuurdoelen in De Wieden (No. 1999). Alterra.Krebs CJ (1999) Ecological methodology. 2nd edition. Addison-Welsey Educational Publishers. 620 pp.

Klijn, F., \& de Haes, H. A. U. (1994). A hierarchical approach to ecosystems and its implications for ecological land classification. Landscape ecology, 9(2), 89-104.

Kwaad F.J.P.M. 1961. Een onderzoek naar de morfogenese van midden West-Friesland. West-Frieslands Oud en Nieuw 28: $1-50$.

Kwaad F.J.P.M., Riezebos P.A. \& Slotboom R.T. 1965. Een bijdrage tot de datering van het oppervlakteveen in Noord-Holland. West-Frieslands Oud en Nieuw 32: 144-152.

Leps, M., Tonkin, J. D., Dahm, V., Haase, P., \& Sundermann, A. (2015). Disentangling environmental drivers of benthic invertebrate assemblages: the role of spatial scale and riverscape heterogeneity in a multiple stressor environment. Science of the Total Environment, 536, 546-556.

Lévêque, C. (2003). Ecology: from ecosystem to biosphere. CRC Press.

Levin, S. A. (1992). The problem of pattern and scale in ecology: the Robert H. MacArthur award lecture. Ecology, 73(6), 1943-1967.

Lewis P.A., Klemm D.J. \& W.T. Thoeny (2001). Perspectives in the use of a multimetric lake bioassessment integrity index using benthic invertebrates. Northeastern Naturalist 8(2): 233-246.

Liess, M. \& P.C von der Ohe (2005). Analyzing effects of pesticides on invertebrate communities in streams. Environmental Toxicology and Chemistry 24: 954-965.

Linke, S., Norris, R. H., Faith, D. P., \& Stockwell, D. (2005). ANNA: a new prediction method for bioassessment programs. Freshwater Biology, 50(1), 147-158.

Lucassen E.C.H.E.T. 2004. Biogeochemical constraints for restoration of sulphate-rich fens. Proefschrift, Katholieke Universiteit Nijmegen.

Lücke J.D. \& R.K. Johnson (2009). Detection of ecological change in stream macroinvertebrate assemblages using single metric, multimetric or multivariate approaches. Ecological indicators 9: 659-669.

Magnuson, J. J. (1990). Long-term ecological research and the invisible present. BioScience, 40(7), 495-501.

Magurran A.E. (2004). Measuring biological diversity. Blackwell Publishing. 256 pp.

McIntosh, A. R., Leigh, C., Boersma, K. S., McHugh, P. A., Febria, C., \& García-Berthou, E. (2017). Food webs and trophic interactions in intermittent rivers and ephemeral streams. In Intermittent Rivers and ephemeral streams (pp. 323-347). Academic Press.

Meinardi C.R. 1980. Schets van de natuurlijke samenstelling van het zoete grondwater in Nederland. RID-mededeling 80-9. Rijksinstituut voor Drinkwatervoorziening, Voorburg.

Menetrey N., Sager L., Oertli B. \& J-B. Lachavanne (2005). Looking for metrics to assess the trophic state of ponds. Macroinvertebrates and amphibians. Aquatic Conservation: marine and freshwater ecosystems 15: 653-664. 
Mennema, J. (1978). Floristisch onderzoek naar Van Soests plantengeografische districten van Nederland. Gorteria, 9(5), 142-154.

Mermillod-Blondin, F., \& Rosenberg, R. (2006). Ecosystem engineering: the impact of bioturbation on biogeochemical processes in marine and freshwater benthic habitats. Aquatic sciences, 68(4), 434-442.

Minshall, G. W. (1988). Stream ecosystem theory: a global perspective. Journal of the North American Benthological Society, 7(4), 263-288.

Mol, A.W.M. (1985). Hydrobiologische districten in Nederland. RIN-rapport 85/7. Rijksinstituut voor Natuurbeheer, Leersum. 50 p.

Molen, D. T. van der (2000) Natuurlijke levensgemeenschappen van de Nederlandse binnenwateren deel 9, Rijkswateren. Achtergronddocument bij het 'handboek natuurdoeltypen in Nederland', Rapport EC-LNV AS-09.

Naiman, R. J., Elliott, S. R., Helfield, J. M., \& O’keefe, T. C. (1999). Biophysical interactions and the structure and dynamics of riverine ecosystems: the importance of biotic feedbacks. In Man and River Systems (pp. 79-86). Springer, Dordrecht.

Newbold, J. D., O’Neill, R. V., Elwood, J. W., \& Van Winkle, W. (1982). Nutrient spiralling in streams: implications for nutrient limitation and invertebrate activity. The American Naturalist, 120(5), 628-652.

Niemi G.J. \& M.E. McDonald (2004). Application of ecological indicators. Annual Reviews of Ecology, Evolution and Systematics 35: 89-111.

Nijboer R. Jaarsma N., Verdonschot P., Molen D. van der, Geilen N. \& Backx J. (2000): Natuurlijke levensgemeenschappen van de Nederlandse binnenwateren. Deel 3. Wateren in het rivierengebied. Achtergronddocument bij het 'Handboek Natuurdoeltypen in Nederland'., 2000. Rapport AS-03, EC-LNV. Alterra, Wageningen. Werkdoc. RIZA 2000.155X, 153 pp.

Nijboer R.C. \& Verdonschot P.F.M. (1997): Habitatsystemen als graadmeter voor natuur in de zoete rijkswateren. Natuurverkenningen '97, Achtergronddocument 2B, Informatie- en KennisCentrum Natuurbeheer, Wageningen. 148 pp.

Nijboer R.C. (2006). The myth of communities. Detecting ecological quality of surface waters using macroinvertebrate community patterns. Alterra Scientific Contributions 17, Alterra Wageningen UR.

Nijboer R.C., Verdonschot P.F.M. \& van den Hoorn M.W. 2003. Macrofauna en vegetatie van de Nederlandse sloten. Een aanzet tot beoordeling van de ecologische toestand. Alterra rapport 688, Wageningen. 255 pp.

Nijboer, R. C. (2000). Natuurlijke levensgemeenschappen van de Nederlandse binnenwateren deel 6, sloten; achtergronddocument bij het'Handboek Natuurdoeltypen in Nederland' (No. AS-06). EC-LNV.

Nijboer, R. C., Verdonschot, P. F. M., \& van den Hoorn, M. W. (2003). Macrofauna en vegetatie van de Nederlandse sloten; een aanzet tot beoordeling van de ecologische toestand. Alterra, Wageningen. Rapport nr. 688.

Nijboer, R. C., Verdonschot, P. F. M., Johnson, R. K., Sommerhäuser, M., \& Buffagni, A. (2004). Establishing reference conditions for European streams. In Integrated Assessment of Running Waters in Europe (pp. 91-105). Springer, Dordrecht.

Organisation for Economic Cooperation and Development (OECD) (1993). Core set of indicators for Environmental Performance Reviews. Environ. Monogr. 83. OECD, Paris, France.

Parsons, M., Thoms, M. C., \& Norris, R. H. (2004). Using hierarchy to select scales of measurement in multiscale studies of stream macroinvertebrate assemblages. Journal of the North American Benthological Society, 23(2), 157-170.

Paulissen, M. P. C. P., Nijboer, R. C., \& Verdonschot, P. F. M. (2007). Grondwater in perspectief; een overzicht van hydrochemische watertypen in Nederland (No. 1447). Alterra.

Pauw, de N. \& G. Vanhooren (1983). Method for biological quality assessment of watercourses in Belgium. Hydrobiologia 100: $153-168$.

Pickett, S. T. A., \& P. S. White (editors) (1985). The ecology of natural disturbance and patch dynamics. Academic Press, Orlando, Florida.

Piket, J.J.C. (1987). Atlas van Nederland. Part 16: Landschap. Staatsuitgeverij, The Hague.

Poff N.L. (1997). Landscape filters and species traits: towards mechanistic understanding and prediction in stream ecology. Journal of the North American Benthological Society 16(2): 391-409.

Poff N.L., Olden J.D., Vieira N.K.M., Finn D.S., Simmons M.P. \& B.C. Kondratieff (2006). Functional trait niches of North American lotic insects: traits-based ecological applications in light of phylogenetic relationships. Journal of the North American Benthological Society 25: 730-755.

Poff, N. L., \& Ward, J. V. (1989). Implications of streamflow variability and predictability for lotic community structure: a regional analysis of streamflow patterns. Canadian journal of fisheries and aquatic sciences, 46(10), 1805-1818. 
Poff, N. L., \& Ward, J. V. (1990). Physical habitat template of lotic systems: recovery in the context of historical pattern of spatiotemporal heterogeneity. Environmental management, 14(5), 629.

Poff, N. L., Brinson, M. M. \& Day Jr, J. W. (2002). Aquatic ecosystems and global climate change: Arlington, VA: Pew Center on Global Climate Change.

Polis, G. A., Anderson, W. B., \& Holt, R. D. (1997). Toward an integration of landscape and food web ecology: the dynamics of spatially subsidized food webs. Annual review of ecology and systematics, 28(1), 289-316.

Pons L.J. 1992. Holocene peat formation in the lower parts of the Netherlands. In: Verhoeven J.T.A. (red.). Fens and bogs in the Netherlands: vegetation, history, nutrient dynamics and conservation. Kluwer, Dordrecht.

Provincie Gelderland 1995. Een Gelders Maatweb. Een ecologisch beheersinstrument voor sloten, weteringen en genormaliseerde laaglandbeken in Gelderland op basis van de macrofauna. Provincie Gelderland, juni 1995.45 pp. + bijlagen.

Reiss, J., Bridle, J.R., Montoya, J.M. \& Woodward, G., 2009. Emerging horizons in biodiversity and ecosystem functioning research. Trends in Ecology and Evolution 24: 505-514.

Reynolds, C. S. (1998). What factors influence the species composition of phytoplankton in lakes of different trophic status?. Hydrobiologia, 369, 11-26.

Reynoldson T.B., Norris R.H., Resh V.H., Day K.E. \& D.M. Rosenberg (1997). The reference condition: a comparison of mutlimetric and multivariate approaches to assess water quality impairment using macroinverterbates. Journal of the North American Benthological Society 16: 833-852.

Ricciardi, A. (2001). Facilitative interactions among aquatic invaders: is an" invasional meltdown” occurring in the Great Lakes?. Canadian journal of fisheries and aquatic sciences, 58(12), 2513-2525.

Richards, C., Johnson, L. B., \& Host, G. E. (1996). Landscape-scale influences on stream habitats and biota. Canadian Journal of Fisheries and aquatic sciences, 53(S1), 295-311.

Schindler, D. E., \& Scheuerell, M. D. (2002). Habitat coupling in lake ecosystems. Oikos, 98(2), 177-189.

Schouwenaars J.M., Esselink H., Lamers L.P.M. \& Van der Molen P.C. 2002. Ontwikkeling en herstel van hoogveensystemen. Bestaande kennis en benodigd onderzoek. Expertisecentrum LNV, Wageningen.

Siepel, H., (1994). Structure and function of soil microarthropod communities. Thesis Wageningen. 136 pp.

Simpson J. \& R.H. Norris (2000). Biological assessment of water quality: development of AUSRIVAS models and outputs. pp. 125-142. In: Wright JF, Sutcliffe DW \& MT Furse (eds.) RIVPACS and similar techniques for assessing the biological quality of freshwaters. Freshwater Biological Association. 373 pp.

Sinkeldam J.A., Nijboer R.C. \& Verdonschot P.F.M. (1998): Typologie van diatomeeëngemeenschappen in Overijssel. IBN-rapport 360, 1-134.

Skriver J., Friberg N. \& J. Kirkegaard (2000). Biological assessment of water course quality in Denmark: introduction of the Danish Stream Fauna Index (DSFI) as the official biomonitoring method. Verhandlungen des Internationalen Verein Limnologie 27: 1822-1830.

Sláde ek, V. (1966). Water quality system: With 3 figures and 2 tables in the text. Internationale Vereinigung für theoretische und angewandte Limnologie: Verhandlungen, 16(2), 809-816.

Solimini A.G., Bazzanti M., Ruggiero A. \& G. Carchini (2008). Developing a multimetric index of ecological integrity based on macroinvertebrates of mountain ponds in central Italy. Hydrobiologia 597: 109-123.

Southwood T.R.E. (1988). Tactics, strategies and templets. Oikos 52(1): 3-18.

Southwood, T.R.E., (1977). Habitat, the templet for ecological strategies? Presidential address to British Ecological Society, 5 January 1977. Journal of Animal Ecology 46 (2): 337-365.

Sponseller, R. A., Benfield, E. F., \& Valett, H. M. (2001). Relationships between land use, spatial scale and stream macroinvertebrate communities. Freshwater biology, 46(10), 1409-1424.

Stevenson, R.J., Bothwell, M.L. \& Lowe, R.L. (1996). Algal Ecology: Freshwater Benthic Ecosystems. San Diego: Academic Press.

Stoddard J.L., Herlihy A.T., Peck D.V., Hughes R.M., Whittier T.R. \& E. Tarquinio (2008). A process for creating multimetric indices for large-scale aquatic surveys. Journal of the North American Benthological Society 27(4): 878-891.

STOWA (2014). Ecologische sleutelfactoren. Begrip van het watersysteem als basis voor beslissingen. Publicatie STOWA 2014-19: 47 pp. Amersfoort. 
Tolkamp, H. H. (1980). Organism-substrate relationships in lowland streams (Doctoral dissertation, Pudoc, Centre for Agricultural Publishing and Documentation).

Tonn, W. M. (1990). Climate change and fish communities: a conceptual framework. Transactions of the American Fisheries Society, 119(2), 337-352.

Townsend, C. R. \& Hildrew, A. G. (1994). Species traits in relation to a habitat templet for river systems. Freshwater Biology 31: 265- 275 .

Townsend, C. R., Hildrew, A. G., \& Francis, J. (1983). Community structure in some southern English streams: the influence of physicochemical factors. Freshwater biology, 13(6), 521-544.

Trigal C., García-Criado F. \& C. Fernández-Aláez (2006). Among-habitat and temporal variability of selected macroinvertebratebased metrics in a Mediterranean shallow lake (NW Spain). Hydrobiologia 563: 371-384.

Turner, M. G., Dale, V. H., \& Gardner, R. H. (1989). Predicting across scales: theory development and testing. Landscape ecology, 3(3-4), 245-252.

Usseglio-Polatera P., Bournaud M., Richoux P. \& H. Tachet (2000). Biomonitoring through biological traits of benthic invertebrates: how to use species trait databases? Hydrobiologia 422/423: 153-162.

Vadeboncoeur, Y., Vander Zanden, M. J., \& Lodge, D. M. (2002). Putting the Lake Back Together: Reintegrating Benthic Pathways into Lake Food Web Models: Lake ecologists tend to focus their research on pelagic energy pathways, but, from algae to fish, benthic organisms form an integral part of lake food webs. Bioscience, 52(1), 44-54.

van der Hoek, W. F., Verdonschot, P. F. M., Runhaar, J., Gardeniers, J. J. P. \& Peeters, E. T. H. M. (1994). Naar een landelijk aquatisch ingreep-effectmodel (vooronderzoek PAW* AQUAREGI): toetsing van de bruikbaarheid van een aquatische ecotooptypenmethode en een ecologische waterbeoordelingsmethode (No. 117). IBN-DLO.

Van der Maarel, E. and Dauvellier, P.L, 1978. Naar een Globaal Ecologisch Model voor de ruimtelijke ontwikkeling van Nederland. Staatsuitgeverij, The Hague.

Van der Molen, D. T., R. Pot, C. H. M. Evers, F. C. J. van Herpen \& van Nieuwerburgh L. L. J. (2018). Referenties en maatlatten voor natuurlijke watertypen voor de kaderrichtlijn water 2021-2027. STOWA rapport 2018-49.

Van Wirdum, G., Den Held, A. J., \& Schmitz, M. (1992). Terrestrializing fen vegetation in former turbaries in the Netherlands. In Fens and Bogs in the Netherlands (pp. 323-360). Springer, Dordrecht.

Vannote, R. L., Minshall, G. W., Cummins, K. W., Sedell, J. R., \& Cushing, C. E. (1980). The river continuum concept. Canadian journal of fisheries and aquatic sciences, 37(1), 130-137.

Verberk, W. C. E. P., Verdonschot, P. F. M., van Haaren, T., van Maanen, B. (2012). Milieu- en habitatpreferenties van Nederlandse zoetwatermacrofauna. WEW Themanummer 23, Van de Garde-Jémé, Eindhoven. 32 pp.

Verberk, W.C.E.P., (2008). Matching species to a changing landscape: aquatic macroinvertebrates in a heterogeneous landscape. Thesis Radboud University Nijmegen. 150 pp.

Verdonschot P. et al. (red.) (1995): Beken stromen. Leidraad voor ecologisch beekherstel. Werkgroep Ecologisch Waterbeheer, subgroep Beekherstel, WEW-06. Stichting Toegepast Onderzoek Waterbeheer, STOWA 95-03, Utrecht. 1-236.

Verdonschot P. F .M., Nijboer R. C., Jansen S. N. \& van der Hoorn M. W. (2000b). Waterstreefbeelden en regionale watersysteemverkenningen Limburg. Ecologische typologie, ontwikkelingsreeksen en waterstreefbeelden. Deelproject IIa: Ecologisch-typologische analyses. Alterra, Wageningen. 171.2, Wageningen. 165 pp.

Verdonschot P. F. M. \& Nijboer R. C. (2000d). Waterstreefbeelden en regionale watersysteem-verkenningen Limburg. Ecologische typologie, ontwikkelingsreeksen en waterstreefbeelden. Deelproject III: Referentiegemeenschappen. Alterra, Wageningen. Alterra rapport 171.4, Wageningen. 79 pp.

Verdonschot P. F. M. (2000): Natuurlijke levensgemeenschappen van de Nederlandse binnenwateren. Deel 112. Achtergronddocument bij het 'Handboek Natuurdoeltypen in Nederland'. Rapport AS-01 t/m AS-12, EC-LNV. Alterra, Wageningen.

Verdonschot P. F. M., Driessen J. M. C., Mosterdijk H. G. \& Schot J. A. (1998). The 5-S-Model, an integrated approach for stream rehabilitation. In: H.O. Hansen \& B.L. Madsen, River Restoration '96, Session lectures proceedings. International Conference arranged by the European Centre for River Restoration: 36-44. National Environmental Research Institute, Denmark. 
Verdonschot P. F. M., Nijboer R. C., \& Jansen S. N. (2000a). Waterstreefbeelden en regionale watersysteemverkenningen Limburg. Ecologische typologie, ontwikkelingsreeksen en waterstreefbeelden. Deelproject I: Ruwe indeling in beektypen. Alterra, Wageningen. 171.1, Wageningen. $116 \mathrm{pp}$.

Verdonschot P. F. M., Nijboer R. C., Jansen S. N. \& van der Hoorn M. W. (2000c). Waterstreefbeelden en regionale watersysteemverkenningen Limburg. Ecologische typologie, ontwikkelingsreeksen en waterstreefbeelden. Deelproject IIb: Cenotypenbeschrijvingen. Alterra, Wageningen. 171.3, Wageningen. 235 pp.

Verdonschot P.F.M. \& Nijboer R.C. 2000. Waterstreefbeelden en regionale watersysteem-verkenningen Limburg. Ecologische typologie, ontwikkelingsreeksen en waterstreefbeelden. Deelproject III: Referentiegemeenschappen. Alterra, Wageningen. Alterra rapport 171.4, Wageningen. 79 pp.

Verdonschot P.F.M. \& Nijboer R.C., 2004. Macrofauna en vegetatie van de Nederlandse beken. Een aanzet tot beoordeling van de ecologische toestand. Wageningen, Alterra, Research Instituut voor de Groene Ruimte. Alterra rapport 756, Wageningen. 326 pp.

Verdonschot P.F.M. \& R.C. Nijboer (2000). Typology of macrofaunal assemblages applied to water and nature management: a Dutch approach. pp. 241-262. In: Wright JF, Sutcliffe DW \& MT Furse (eds.) RIVPACS and similar techniques for assessing the biological quality of freshwaters. Freshwater Biological Association. 373 pp.

Verdonschot P.F.M. (1990). Ecologische karakterisering van oppervlaktewateren in Overijssel. Provincie Overijssel, Rijksinstituut voor Natuurbeheer. 301 pp.

Verdonschot P.F.M. (2000): Natuurlijke levensgemeenschappen van de Nederlandse binnenwateren. Deel 1, Bronnen. Achtergronddocument bij het 'Handboek Natuurdoeltypen in Nederland'. Rapport AS-01, EC-LNV. Alterra, Wageningen. 88 pp.

Verdonschot P.F.M. (2000): Natuurlijke levensgemeenschappen van de Nederlandse binnenwateren. Deel 2, Beken. Achtergronddocument bij het 'Handboek Natuurdoeltypen in Nederland'. Rapport AS-02, EC-LNV. Alterra, Wageningen. 128 pp.

Verdonschot P.F.M., Koopmans M. \& Gerritsen R.C. (1999): Ecologisch maatweb stromende wateren. Waterschap Veluwe en Waterschap Vallei \& Eem. 142 pp.

Verdonschot P.F.M., Nijboer R.C., Higler L.W.G. \& TjH. van den Hoek (2003). Selectie van indicatoren voor oppervlaktewateren. Invulling van indicatieve macrofauna, macrofyten en vissen voor Kaderrichtlijn Water typen. Alterra-rapport 865. 190 pp.

Verdonschot, P. F. M. (1983). Ecologische karakterisering van oppervlaktewater in Overijssel. H20 16: 574-579.

Verdonschot, P. F. M. (1990). Ecological characterization of surface waters in the province of Overijssel, The Netherlands (Doctoral dissertation, Verdonschot).

Verdonschot, P. F. M. (1990). Ecologische karakterisering van oppervlaktewateren in Overijssel: het netwerk van cenotypen als instrument voor ecologisch beheer, inrichting en beoordeling van oppervlaktewateren. Provincie Overijssel.

Verdonschot, P. F. M. (2015). Ecologisch raamwerk voor aquatische ecosystemen (No. 2015-29). Stowa.

Verdonschot, P. F. M. (2016). Globale werkwijze voor het uitvoeren van een Stroomgebiedsbrede Ecologische Systeemanalyse (SESA) binnen het beheersgebied van het Waterschap Peel en Maasvallei. Notitie Zoetwaterecosystemen, Alterra, Wageningen UR, Wageningen. 81 pp.

Verdonschot, P. F. M., \& Nijboer, R. C. (2004). Macrofauna en vegetatie van de Nederlandse beken. Alterra, Wageningen. Rapport nr. 756.

Verdonschot, P. F. M., Nijboer, R. C., Higler, L. W. G., \& van den Hoek, T. H. (2003). Selectie van indicatoren voor oppervlaktewateren; invulling van indicatieve macrofauna, macrofyten en vissen voor Kaderrichtlijn Water typen (No. 865). Alterra.

Verdonschot, P. F. M., Runhaar, J., van der Hoek, W. F., De Bok, C. F. M. and Specken, B. P. M. (1992). Aanzet tot een ecologische indeling van oppervlaktewateren in Nederland. RIN-report 92/1/CML-report 78, Leersum.

Verdonschot, P. F. M., Spears, B. M., Feld, C. K., Brucet, S., Keizer-Vlek, H., Borja, A., Elliott M., Kernan M. \& Johnson, R. K. (2013). A comparative review of recovery processes in rivers, lakes, estuarine and coastal waters. Hydrobiologia, 704(1), 453-474.

Verdonschot, P. F. M., Verdonschot, R. C. M., \& Besse-Lototskaya, A. A. 2015. ESF stromende wateren en stroomgebiedsbrede ecologische systeemanalyse. H2O online, (28 augustus). 
Verdonschot, P.F.M. \& Jansen S.N. (2000): Natuurlijke levensgemeenschappen van de Nederlandse binnenwateren. Deel 12. Zoete duinwateren. Achtergronddocument bij het 'Handboek Natuurdoeltypen in Nederland'. Rapport AS-12, EC-LNV. Alterra, Wageningen. 78 pp.

Verdonschot, R. C. M., \& Verdonschot, P. F. M. (2010). Methodiek waardering aquatische natuurkwaliteit: ontwikkeling van graadmeters voor sloten en beken (No. 113). Wettelijke Onderzoekstaken Natuur \& Milieu.

Verdonschot, R.C.M., \& Verdonschot, P.F.M. (2012). Habitat- en systeemgeschiktheid van beeksystemen voor beekvissen. Rapport nr. 2012/OBN168-BE, Directie Agrokennis, Ministerie van Economische Zaken, Den Haag. 77 pp.

Verhoeven, J. T. (Ed.). (2013). Fens and bogs in the Netherlands: vegetation, history, nutrient dynamics and conservation (Vol. 18). Springer Science \& Business Media.

Verhoeven, J. T., Maltby, E., \& Hefting, M. M. (2007). Wetlands and water quality. Ramsar Convention, Gland, April 2007. $55 \mathrm{pp}$.

Vilar, A. G., van Dam, H., Vonk, J. A., van der Geest, H. G., \& Admiraal, W. (2014). Typology of diatom communities in the Dutch delta: Recognizing patterns of environmental drivers in nutrient rich ditches. Ecological indicators, 45, 561-569.

Wellborn, G. A., Skelly, D. K., \& Werner, E. E. (1996). Mechanisms creating community structure across a freshwater habitat gradient. Annual review of ecology and systematics, 27(1), 337-363.

Whittaker, R. H. (ed.) 1978. Ordination of plant communities. Junk, The Hague.

Wolf, B., Kiel, E., Hagge, A., Krieg, H. J., \& Feld, C. K. (2009). Using the salinity preferences of benthic macroinvertebrates to classify running waters in brackish marshes in Germany. Ecological Indicators, 9(5), 837-847.

Wright J.F., Armitage P.D., Furse M.T. \& D. Moss (1989). Prediction of invertebrate communities using stream measurements. Regulated Rivers: Research \& Management 4: 147-155.

Wright, J. F., Moss, D., Armitage, P. D., \& Furse, M. T. (1984). A preliminary classification of running water sites in Great Britain based on macro invertebrate species and the prediction of community type using environmental data. Freshwater biology, 14(3), 221-256.

Zagwijn W.H. 1986. Nederland in het Holoceen. Tien palaeogeographische kaarten, schaal $1: 500,000$. Staatsuitgeverij, Den Haag.

Zelinka M. \& P. Marvan (1961). Zur Präzisierung der biologischen Klassifikation der Reinheit fliessender Gewässer. Archiv für Hydrobiologie 57: 389-407. 
(1) Waterkisimpuls 